\title{
PATENTS AND MEDICAL BIOTECHNOLOGY: AN EMPIRICAL ANALYSIS OF ISSUES FACING THE AUSTRALIAN INDUSTRY
}

DIANNE NICOL AND JANE NIELSEN

CENTRE FOR LAW AND GENETICS OCCASIONAL PAPER No. 6 


\section{All rights reserved}

Copyright (C2003 University of Tasmania, Dianne Nicol and Jane Nielsen

Apart from fair dealing for the purposes of study, research, criticism or review, as permitted under copyright law, no part of this publication shall be reproduced by any process without written permission of the owners of copyright. Inquiries should be made to the authors or publisher.

National Library of Australia Cataloguing-in-Publication Data

\section{ISSN 1445-2766}

This issue may be cited as:

Centre for Law and Genetics Occasional Paper No. 6 (2003).

Published by

Centre for Law and Genetics

Printed by

Faculty of Law

UniPrint

University of Tasmania

University of Tasmania

Private Bag 89

Private Bag 15

Hobart Tasmania 7001

Hobart Tasmania 7001

Australia

Australia 


\section{TABLE OF CONTENTS}

Preface

viii

Abstract

$\mathrm{X}$

PART 1: CONTEXTUALISING THE ISSUES

Context Chapter 1: Aims of this Study 3

Context Chapter 2: Background 6

The Role of Patents in the Australian Medical

Biotechnology Industry 6

Medical Biotechnology Research in Australia 12

$\begin{array}{ll}\text { Other Empirical Studies } & 16\end{array}$

Context Chapter 3: Patenting of Biotechnology

Inventions in Australia $\quad 20$

Patentability Requirements 20

Use Of Patents 34

Patent Activity in Australia 38

Context Chapter 4: Impact of Patents on Medical Biotechnology

Research and Development $\quad 50$

Patents and Public Sector Research 50

Restrictions on Access to Upstream Patents 53

The Tragedy of the Anticommons 56 
The Consumer Perspective - Restrictions on Access to

Biotechnology-Related Products $\quad 57$

Context Chapter 5: Study Methods $\quad 64$

$\begin{array}{ll}\text { Surveys } & 64\end{array}$

$\begin{array}{ll}\text { Interviews } & 67\end{array}$

PART 2: RESULTS OF THE EMPIRICAL STUDY

Results Chapter 1: Research And Patent Issues 75

$\begin{array}{ll}\text { Patent Activity } & 76\end{array}$

$\begin{array}{ll}\text { Views On Patents } & 81\end{array}$

Results Chapter 2: Transfer of Technology 93

Survey Data on Collaborative Activity 94

Survey Data on Licensing-out Activity 100

Licensing, Assignment and Mergers 103

Technology Transfer Issues for Research Institutions 105

Technology Transfer from Upstream to Downstream

$\begin{array}{ll}\text { Industry Sectors } & 110\end{array}$

$\begin{array}{ll}\text { Licensing-in } & 114\end{array}$

$\begin{array}{ll}\text { Licence Terms } & 115\end{array}$

$\begin{array}{ll}\text { Summary } & 122\end{array}$

Results Chapter 3: Impact of Patents on the Research Sector 124

Changing Attitudes towards Commercialisation of

ii 
Biotechnology Research $\quad 125$

Effect of Patents on Publication $\quad 126$

Quantum and Quality Issues $\quad 130$

Ownership and Clean Title 132

Under- and Over-Valuing 134

$\begin{array}{ll}\text { Summary } & 136\end{array}$

Results Chapter 4: Restrictions on Access to Upstream $\begin{array}{ll}\text { Patents } & 137\end{array}$

Blocking Patents 140

Refusals to Licence $\quad 145$

$\begin{array}{ll}\text { Exclusivity } & 150\end{array}$

Costs and Delays Associated with Licensing Patents 156

$\begin{array}{ll}\text { Restrictive Terms } & 160\end{array}$

$\begin{array}{ll}\text { Failure to Exploit Patents } & 168\end{array}$

$\begin{array}{ll}\text { Summary } & 172\end{array}$

Results Chapter 5: Anticommons Issues 174

Preconditions to an Anticommons in Australia $\quad 176$

$\begin{array}{ll}\text { Patent Searching Obligations } & 178\end{array}$

Survey Data on Number of In-Licences 184

Number of In-licences and Project Abandonment 186

$\begin{array}{ll}\text { Royalty Stacking } & 191\end{array}$

Reach-through Right Stacking 193

$\begin{array}{ll}\text { Summary } & 194\end{array}$ 
Results Chapter 6: Supply to End Users 196

$\begin{array}{ll}\text { Pharmaceuticals } & 196\end{array}$

$\begin{array}{ll}\text { Devices } & 198\end{array}$

$\begin{array}{ll}\text { Diagnostics } & 198\end{array}$

$\begin{array}{ll}\text { Summary } & 205\end{array}$

Results Chapter 7: Market Solutions 208

Collaborations and Licensing 208

$\begin{array}{ll}\text { Inventing Around } & 211\end{array}$

$\begin{array}{ll}\text { Patent Enforcement } & 214\end{array}$

Research Exemption $\quad 218$

Challenges to Validity 222

$\begin{array}{ll}\text { Summary } & 224\end{array}$

PART 3: OUTCOMES OF THIS STUDY: THE WAY FORWARD

\section{Outcomes Chapter 1: The Legal Landscape And Options}

\section{For Reform 229}

Excluding Gene Sequences $\quad 231$

Excluding Diagnostic Tests 233

Public Interest Provision 233

Increasing The Stringency Of Patent Invention and

Disclosure Requirements 234

Exemptions From Infringement 236 
Compulsory Licensing / Government Use Provisions 236

Fair Use And Automatic/ Statutory Licensing 239

Collective Rights Organisations 242

The Role Of Competition Law 244

$\begin{array}{ll}\text { Summary } & 248\end{array}$

Outcomes Chapter 2: Conclusions 250

$\begin{array}{ll}\text { Study Findings } & 250\end{array}$

Reform Options 258

$\begin{array}{ll}\text { Bibliography } & 261\end{array}$ 
Table 1: Patents linked to cessation of tests in the US and equivalent Australian patents

Table 2: $\quad$ Interview respondents

Table 3: Numbers of patents held

Table 4: Types of patents held

Table 5: General views on the impact of patents on research

Table 6: Views on the impact of types of patents on research

Table 7: Collaborative activity: research institution survey respondents

Table 8: Types of collaborators and their geographical location: research institution survey respondents

Table 9: Types of collaborators: company survey respondents

Table 10: Types of collaborators: diagnostic facility survey results

Table 11: Number and types of out-licences: research institution and company results

Table 12: Company and research institution respondents with patents but with no out-licences

Table 13: Views on the impact of patents on publication in the research institution and diagnostics sectors

Table 14: Numbers and types of in-licences 
Table 15: Location of laboratory 199

Table 16: Types of tests 200

Table 17: Cost of tests 200

Table 18: Payment of licence fees or royalties 201

$\begin{array}{ll}\text { Table 19: Notifications } & 201\end{array}$

Table 20: Views on the impact of patents on diagnostic tests 


\section{PREFACE}

We are most grateful to all the people who participated in this study, particularly those people who agreed to be interviewed. Thank you for giving up so much of your valuable time and for your candour, patience and good humour.

This research was supported by a University of Tasmania Institutional Research Grant (N0012490). Funding was also provided from grant DP0208258 from the Australian Research Council Discovery Grant Scheme. The study was approved by the Southern Tasmania Social Sciences Human Research Ethics Committee.

We would like to thank Bruce Newey, Tim Graham, Rebecca Keep, Brendan Gogarty and Liz Sharp for research assistance. We also thank Rhys Edwards for assisting us in the design of our surveys and for other advice during the course of this study. We are grateful to both Mildred Cho and John Walsh for visiting us and generously providing us with their insight and guidance.

We thank Donald Chalmers, Lynden Griggs, Matthew Rimmer, Andrew Christie, Joshua Gans, Amanda Lim, John Walsh, Tim Caulfield, Margaret Llewelyn and the Australian Law Reform Commission commissioners and staff involved in the gene patenting reference for commenting on drafts of this Report.

Some of the material in this Report has previously been published. Where necessary, permission has been granted to use this material. See particularly:

D. Nicol 'The Impact of Patents on the Delivery of Genetic Tests in Australia' (2003) 15(5) Today's Life Science22-27

D. Nicol 'Patents and Access to Genetic Tests' Centre for Law and Genetics Symposium Breaking the Code Murdoch Children's Research Institute And Walter And Eliza Hall Institute, Melbourne 28 and 29 November 2002. In: Centre for Law and Genetics Occasional Paper No 5 (2003)

D. Nicol 'Patents and Access to Drugs' Centre for Law and Genetics Symposium Regulating the New Frontiers: Legal Issues in Biotechnology, University of Tasmania 10 December 2001. In: Centre for Law and Genetics Occasional Paper No 4 (2002) 52. 
D. Nicol 'Tissue Donations and Patents' Centre for Law and Genetics Symposium Regulating Human Genetics, University of Tasmania November 2000. In: Centre for Law and Genetics Occasional Paper No 3 (2001) 43.

J. Nielsen 'Biotechnology Patent Licensing Agreements and Anti-competitive Conduct' Centre for Law and Genetics Symposium Regulating the New Frontiers: Legal Issues in Biotechnology, University of Tasmania 10 December 2001. In: Centre for Law and Genetics Occasional Paper No 4 (2002) 35.

We also rely heavily on our article:

D. Nicol and J. Nielsen 'The Australian Medical Biotechnology Industry and Access to Intellectual Property: Issues for Patent Law Development' (2001) 23 Sydney Law Review 347-374

All references to the material appearing in this article have been footnoted throughout this Report.

Dianne Nicol is a member of the Advisory Committee to the Australian Law Reform Commission's inquiry Gene Patenting and Human Health. The views expressed in this Report are those of the authors and are not in any way connected with the Australian Law Reform Commission or the Advisory Committee.

Some of the material in this Report also appears in Jane Nielsen's $\mathrm{PhD}$ thesis. Those parts were written solely by her.

To the best of the authors' knowledge, the literature relied upon in this Report was current as at 23 December 2003. 


\section{EXECUTIVE SUMMARY}

There is ongoing debate both within Australia and internationally about the ways in which patents impact on the medical biotechnology industry. The underlying purpose of the patent system is to encourage innovation by granting the patent holder a temporary monopoly over the patented invention. However, patents can also have a detrimental effect on innovation, for example, by stifling the free flow of information or increasing transaction costs. Gene patents and broadly applicable research tool patents are of particular concern for two main reasons. First, if individual patents are licensed on a restrictive basis, access to broadly applicable foundational technology could be blocked, impeding downstream research and development. Secondly, if it is necessary to enter into licence negotiations over multiple patents, the pace of innovation could be delayed, creating what has become known as an anticommons.

Although there is a large body of theoretical literature on this topic, the empirical literature is only small (but growing). To date, this empirical literature suggests that practical means are being found to work around the negative aspects of patenting in the medical biotechnology industry. In particular, broadly applicable research tools tend to be widely licensed. However, there is some evidence that gene patents are having a negative impact in the diagnostics sector of the industry in the United States.

This study was conducted in order to assess the impact of patents on innovation in the Australian medical biotechnology industry. Surveys were mailed to three industry sectors: research institutions, public and private biotechnology and pharmaceutical companies, and diagnostic facilities. Forty semi-structured interviews were undertaken with participants in all of these sectors.

A summary of the key findings that emerge from the study is presented below.

- Research base Australian research institutions provide a sound research base for the medical biotechnology industry in Australia.

- Patent system

Although the Australian patent system is operating satisfactorily and is consistent with other jurisdictions, there is 
little doubt that better funding of the Australian Patent Office would assist in improving examination standards. It may also be desirable to explore avenues for encouraging challenges to questionable patents.

- Patent enforcement

To date, it appears that the Australian industry has not been exposed to the same level of aggressive enforcement of key research tool patents as in the United States. However, there is no guarantee that this situation will continue.

- Technology transfer

In general, the outward transfer of technology is difficult for all industry sectors. However, industry participants are putting in place arrangements to better manage and exploit their technology. In particular, research institutions are improving their intellectual property management strategies.

- Research institutions

Australian research institutions are facing a number of challenges in the evolving commercial environment in which they have to operate. One of the key issues is the extent to which research conducted in these institutions is immune from patent infringement. The desirability of an express research exemption in Australian patent law is an important issue canvassed in this Report, although uncertainty about the breadth of protection may persist.

- Restrictions on access

There is evidence of exclusionary practices within the Australian industry. Some degree of exclusion is to be expected, particularly when this relates to patents over competing technology, given that this is the nature of a patent grant. However, these practices may be of more concern when they relate to patents over technology that is useful for a range of research uses that may be competing or non-competing. Our findings suggest that instances of such practices are more isolated. The question, then, is whether law reform is necessary. We endorse the findings of other studies, that open science should be vigilantly protected although not at the expense of failing to adequately reward innovation.

- Anticommons

In general the Australian industry seems to be avoiding an anticommons situation, but the potential still exists for its emergence. Ongoing increases in the number of patents, more vigilant enforcement and the increasing complexity of 
research paths may result in the development of an anticommons.

- Diagnostic testing

Although the diagnostic testing sector of the Australian industry has not been exposed to patent enforcement to the same extent as the United States industry, the possibility of more rigorous enforcement practices is ever present.

One of the main conclusions of this Report is that at present the medical biotechnology industry is enjoying the advantages that the patent system offers in encouraging innovation. This does not necessarily mean that the patent system is working perfectly, and consideration of changes to further increase its benefits is warranted. It must be emphasised that a delicate balance exists between the multiple stakeholder interests within the industry, and any consideration of law reform should be investigated thoroughly. Whilst it is recognised that the Australian Patent Office should only grant good quality patents with clear industrial applicability, it is concluded that major reforms to the criteria for patent grant are not warranted. This does not preclude consideration of some modifications to existing patent law in order to fine-tune the processes for assessing patent validity, defences and infringement. Further, options to better regulate the use of patents could also be examined. These options include modification to existing compulsory licensing and government use provisions, the creation of a statutory licensing regime and use of clearing house mechanisms, and further consideration of the role of competition law. 


\section{PART 1: CONTEXTUALISING THE ISSUES}




\section{CONTEXT CHAPTER 1: AIMS OF THIS STUDY}

To date, there has been little or no analysis of the impact of patents and technology transfer on the commercial success of the Australian biotechnology industry, on the capacity of Australian research institutions to continue with their world-class research and on consumer access to the products of biotechnology research, particularly health care products. The challenge is whether the current legal and administrative arrangements are satisfactory, and if not, the extent to which they will need to be reformed.

A number of government-sponsored reports have provided overviews of the state of the biotechnology industry in Australia. For example, Ernst \& Young have published a series of reports, in which they undertook an overview of the biotechnology industry in Australia and other jurisdictions primarily on the basis of survey evidence. ${ }^{1}$ However, to date no study has attempted to comprehensively map the framework of the industry in Australia focusing on patents and technology transfer and how this affects the performance of the industry. The aim of this study is to fill this gap for the Australian industry. Three industry sectors are considered:

- the research sector, including universities, government research laboratories, public and private research institutes and hospitals, which we refer to collectively as research institutions hereafter;

- biotechnology and pharmaceutical companies across the full spectrum, from upstream spin offs from research institutions through to downstream subsidiaries of multinational pharmaceutical companies. We use the terms "upstream" and "downstream" throughout this Report to describe the two ends of the continuum from basic research findings (gene sequences and the like) through to marketable products (drugs, therapies, diagnostics and so on); and

\footnotetext{
${ }^{1}$ See for example, Ernst and Young, Beyond Borders: the Global Biotechnology Report 2003, (Cleveland: Ernst \& Young LLP 2003) (hereafter Ernst \& Young 2003); Ernst \& Young, Australian Biotechnology Report (Commonwealth of Australia, 2001) (hereafter Ernst \& Young 2001); Ernst \& Young, Australian Biotechnology Report (Canberra: AGPS, 1999) (hereafter Ernst \& Young 1999).
} 
- diagnostic facilities offering clinical genetic testing and, in some instances, undertaking diagnostic research.

The complex relationship between patenting, commercialisation of biomedical research and access to new healthcare products is increasingly being debated both nationally and internationally. In addition, the expertise of members of the Centre for Law and Genetics lies primarily in the area of medical law and ethics and to date the research work conducted within the Centre has been focused primarily in these areas. For these reasons, the study reported herein focuses primarily on the Australian medical biotechnology industry, although some data are included from other sectors of the industry for comparative purposes.

Some key areas of inquiry in this study are as follows:

- the nature of the research that is being undertaken by the Australian medical biotechnology industry and the patent activity associated with it;

- whether the Australian industry has the capacity to commercialise its own technology, or has to transfer this technology for others to commercialise;

- the extent of collaborations, assignments and licensing-out of patents held by the Australian industry and the nature of the arrangements;

- the general terms and conditions contained in licences entered into by the Australian industry for the purposes of commercialising research (licensing-out);

- the extent to which the Australian industry needs to obtain authorisation from other patent holders in order to carry out its research and commercialisation, specifically focusing on the types of patents that are being enforced in Australia and the quantum of in-licensing;

- the general terms and conditions contained in licences entered into by the Australian industry for the purposes of obtaining access to patents held by others;

- the particular issues faced by the research institution, diagnostics and private industry sectors.

This study aims to provide data from which an assessment can be made as to whether the Australian industry (both through patents themselves and through technology transfer arrangements) is operating as a branch office of the major overseas companies or is 
establishing itself as a specialised niche market. Three broad questions form the backdrop to this study:

1. is the development of the biotechnology industry in Australia assisted or impeded by biotechnology patents and patent licensing practices?

2. does the social advantage of commercialisation of public sector research, particularly the increased availability of private sector funding, outweigh the social cost, particularly the impact on the traditional norms of science?

3. does the social advantage of biotechnology patents, namely encouraging innovation and product development, outweigh the social cost of the patent monopoly, including the effect on product availability, pricing, diversity and quality.

This foundational information will allow examination of fundamental regulatory questions about how Australian government policy on commercialisation of biotechnology can be implemented and how it can be balanced against other important social values. The results of this study are likely to provide assistance in examining the following regulatory issues:

- the current interpretation of patent law requirements in the context of biotechnology and the extent to which biotechnology patents impact on research and development;

- the current system of contractual assignment and licensing in Australia and the extent to which collaborations, assignments and licensing agreements create rights and obligations that extend beyond the strict confines of the statutory rights granted by patent law;

- the relationship between intellectual property law and government regulation of the biotechnology industry;

- the extent to which patent law shields research institutions and diagnostic facilities from the enforcement of patent rights; and

- the balance between patent rights and access to health care. 


\section{CONTEXT CHAPTER 2: BACKGROUND}

\section{THE ROLE OF PATENTS IN THE AUSTRALIAN MEDICAL BIOTECHNOLOGY INDUSTRY}

Federal and state governments in Australia have expressed a strong commitment to the development of an indigenous biotechnology industry. For example, during the last few years the Federal Government has instructed a number of committees to examine the biotechnology industry in Australia with a view to formulating proposals to provide the necessary impetus to expand the industry. The reports raise a number of relevant considerations that the Government needs to take into account in determining its policy for development of the industry. These include such important factors as:

- creating a seamless flow of knowledge and skills from the public sector to the private sector ${ }^{2}$ through the process of technology transfer and through university-industry research schemes;

- ensuring appropriate management of Australian-owned intellectual property;

- developing appropriate regulatory regimes to adequately safeguard human health and protect the environment but not to unnecessary impede the development of the industry;

- ensuring that appropriate international instruments are in place to protect and support the Australian industry.

The Federal Government's vision for biotechnology has been stated as follows:

Consistent with safeguarding human health and ensuring environment protection, that Australia

\footnotetext{
2 See, for example, Prime Minister's Science, Engineering and Innovation Council, University-Industry Linked Research in Australia (1998), available at: http://www.dest.gov.au/science/pmseic/documents/unind.pdf $\quad$ (accessed 18 November 2003).
} 
capture the benefits of biotechnology for the Australian community, industry and the environment. ${ }^{3}$

One vital issue that the Government has not addressed in any great detail is that of barriers to entry. The biotechnology industry is an archetypal global industry with a global marketplace. If there are significant barriers to entry into the global marketplace for the Australian biotechnology industry then it will be difficult for it to achieve the goals set by government. One of the most significant barriers to entry for Australian companies is likely to be intellectual property. There are two perspectives to this issue:

- if the Australian industry is unable to get access to essential research tools and products as a result of the exercise of intellectual property rights by other participants in the global industry, this will be a significant impediment to its entry into the market; and

- if, at the same time, the Australian industry is unable to adequately protect and exploit its own intellectual property, then this too will be a significant impediment to its entry into the market.

There is a further crucial consideration that needs to be taken into account, as intimated in the Federal Government's vision for biotechnology: that the work conducted by this industry has the potential to affect human health and the environment. This potential can be viewed from both a positive and a negative perspective. Laws relating to intellectual property are not the most appropriate avenues for dealing with the negative impact of biotechnology on human health and the environment. This should largely be left to legislation and administrative procedures specifically set up for the task of assessing safety, efficacy and ethics. However, the availability of intellectual property rights does have an important bearing on the positive effects of biotechnology in relation to human health and the environment. Patent grants are generally justified on the utilitarian ground that they provide the necessary incentive to innovate and that innovation is good for society. The line of argument is that, if

3 Biotechnology Australia, Australian Biotechnology: A National Strategy, (Canberra: Commonwealth of Australia, 2000) at p.7, available at: http://www.biotechnology.gov.au/library/content_library/BA_Biotech_strategy.pdf (accessed 18 November 2003). See also, Biotechnology Australia, Developing Australia's Biotechnology Future, Discussion Paper, (Canberra: Commonwealth of Australia, 1999). 
inventors can recover the costs put into research and development and earn rewards through product pricing and licence fees, they will be encouraged to take their inventions through to commercial production and to create further inventions.

On this basis, the availability of patents for biotechnology inventions will encourage industry participants to make their inventions commercially available, and the availability of these new health care, agricultural and other products derived from biotechnology research is likely have a positive impact on human health and the environment. However, one of the difficulties in this area is that it is not clear how patents and technology transfer arrangements are actually operating in the biotechnology industry as a whole; whether they do indeed encourage innovation and the extent to which they have an effect on other socially desirable goals. Patents grant patent holders and their licensees a period of market exclusivity, which enables them to charge monopoly prices on the sale of their products for the life of the patent and prevent others from using the patented technology for the life of the patent. Although the justification for patents is that they enable innovations in biotechnology to be commercialised, they could, at the same time, be used to block others from innovating. ${ }^{4}$ Thus, it is necessary to consider whether patenting of genes and other biotechnology inventions does indeed achieve the goal of encouraging innovation. It is also necessary to consider whether, in achieving this goal, other public interests might be compromised, particularly the public interest in the process of scientific discovery and the public interest in access to new products developed using biotechnology.

There is a growing recognition that the way in which patents are used could have a significant impact on the progress of biotechnology research and development and the availability of the products of this work. Perhaps these issues are best exemplified in the well known scenario surrounding the use of United States patent 5,753,441 which was filed on 5 January 1996, granted on 19 May 1998 and assigned to Myriad Genetics Inc. The patent is entitled " 170 -linked breast and ovarian cancer susceptibility gene”.

\footnotetext{
${ }^{4}$ For further discussion on this issue see D. Nicol and J. Nielsen, 'The Australian Medical Biotechnology Industry and Access to Intellectual Property: Issues for Patent Law Development' (2001) 23 Sydney Law Review 347 (hereafter Nicol and Nielsen).
} 
Similar patents have been granted to Myriad in Australia, for example patent AU691958, which is entitled "17q-linked breast and ovarian cancer susceptibility gene”. What Myriad has obtained, through these and other patents, is broad claims over mutant BRCA 1 gene sequences and their use in diagnosis and prognosis of breast, ovarian and other cancers, therapies and drugs. The patents include claims to a whole range of methods for identifying, screening and detecting mutant sequences, nucleic acid probes hybridizable to the gene sequences, cloning vectors, expression systems, recombinant host cells, and so on. Myriad has been actively enforcing its patent rights against public and private sector researchers and against laboratories offering BRCA tests in a number of countries. For example, in 2001 it sent enforcement notices (often referred to as "cease and desist" letters) to provincial health service providers in Canada, requiring that all samples were sent to Myriad's own laboratories in Utah for testing. ${ }^{5}$ It has also been reported that Myriad has licensed its BRCA patents to academic institutions. The reported terms of the licences allowed academic researchers to conduct tests provided no fee was charged and no direct clinical use was made of the tests. ${ }^{6}$ This meant that participants could not be informed of their test results. There is a large body of academic and media commentary that is critical of these actions by Myriad. The general line of argument is that this type of action is taking the patent monopoly too far, to the detriment of other socially important values. If this is indeed the case, it is important to know the extent to which other patent holders are engaging in similar behaviour.

Actions by Myriad in relation to the BRCA patents have recently been the subject of some commentary, both academically and in the media, in Australia. ${ }^{7}$ One of the reasons for this was the

\footnotetext{
${ }^{5}$ See, for example, L. Macdonald, Gene Patenting: Is It Too Late To Stop It? Canadian Breast Cancer Network, 24 April 2002, available at: http://www.cbcn.ca/english/adv_db.php?show\&43 (accessed 12 January 2003) (hereafter Macdonald).

6 'Corporate Takeover' The Boston Globe Magazine, 30 June 2002, available at: http://www.boston.com/globe/magazine/2002/0224_patent_part2 (accessed 1 July 2002).

${ }^{7}$ For example, I.R. Walpole, H.J.S. Dawkins, P.D. Sinden and P.C. O’Leary, 'Human Gene Patents: The Possible Impacts on Genetic Service Providers' (2003) 179 Medical Journal of Australia 203-205; D. Nicol, 'Human Gene Patents: Under Whose Control?' (2003) 179 Medical Journal of Australia 181-182; see also Australian Broadcasting Corporation (ABC) Four Corners, 'Patently a Problem' broadcast on 11 August 2003, transcript available at http://www.abc.net.au/4corners/content/2003/transcripts/3922059.htm (accessed 12 August 2003) (hereafter ABC Four Corners).
} 
announcement on 28 October 2002 of a strategic alliance between Myriad and Genetic Technologies, Ltd (GTG), a Melbourne based company, involving the BRCA tests. ${ }^{8}$ This announcement has heightened concerns about the potential impact of enforcement of broad gene patents and other related types of patents by foreign companies like Myriad on the Australian biotechnology industry.

Interestingly, GTG has also been actively enforcing its own patents over the last year or so both within Australia and in other countries. GTG owns a number of patents relating to intron sequence analysis (the so-called junk DNA patents) and others relating to fetal cell recovery, details of which are presented below:

\section{Junk DNA patents}

1. Intron sequence analysis method for detection of adjacent and remote locus alleles as haplotypes. Patent granted by USPTO in 1998 US5,612,179. Granted in Australia AU67519;

2. Genomic mapping by direct haplotyping using intron sequence analysis. Patent granted by USPTO in 1998 US5,851,762. Granted in Australia AU647806;

3. Intron sequence analysis method for detection of adjacent and remote locus alleles as haplotypes. Patent granted by USPTO in 1993 US5,192,659. Granted in Australia AU654111

Patent holder: Genetype AG (Genetic Technologies Ltd)

\section{Fetal cell recovery patents}

1. Fetal cell recovery method. Patent granted by USPTO in 1995 US5,447,842. Granted in Australia AU649027

\footnotetext{
8 'Genetic Technologies and Myriad Genetics Announce Strategic Licensing Agreement', Press Release, 28 October 2002, available at: http://www.gtg.com.au/Media.Coverage.html (accessed 8 December 2003).
} 
2. Fetal cell recovery method. Patent application in Australia 200177352.

The junk DNA patents are most relevant to current discussions. The two intron sequence analysis patents have the following abstract:

The present invention provides a method for detection of at least one allele of a genetic locus and can be used to provide direct determination of the haplotype. The method comprises amplifying genomic DNA with a primer pair that spans an intron sequence and defines a DNA sequence in genetic linkage with an allele to be detected. The primer-defined DNA sequence contains a sufficient number of intron sequence nucleotides to characterize the allele. Genomic DNA is amplified to produce an amplified DNA sequence characteristic of the allele. The amplified DNA sequence is analyzed to detect the presence of a genetic variation in the amplified DNA sequence such as a change in the length of the sequence, gain or loss of a restriction site or substitution of a nucleotide. The variation is characteristic of the allele to be detected and can be used to detect remote alleles. Kits comprising one or more of the reagents used in the method are also described.

Simplistically, what these junk DNA patents claim is a method of using non-coding regions of DNA to predict mutations in active coding regions. ${ }^{9}$ GTG has entered into a number of lucrative licensing arrangements relating to the use of these patents, mainly with United States based companies, but also in Australia, New Zealand and Europe. ${ }^{10}$ Perhaps more controversially, GTG has also announced a research licence with the University of Sydney, ${ }^{11}$ and Dr. Mervyn

\footnotetext{
${ }^{9}$ For a good lay discussion of the issues associated with GTG's patents, see ABC Four Corners, above n7.

${ }^{10}$ See generally announcements on the Genetic Technologies website at:

http://www.gtg.com.au/Media.Coverage.html (accessed 8 December 2003). See particularly: 'Presentation by Dr. Mervyn Jacobson, Executive Chairman, to the Annual General Meeting of Genetic Technologies Limited (“GTG”), Melbourne, November 28th, 2003’.

11 'GTG Grants Research License to University of Sydney', 25 July 2003, available at:

http://www.gtg.com.au/Announcements.html\#25jul (accessed 8 December 2003).
} 
Jacobson, the chief executive officer, has intimated that the junk DNA patents are also being enforced against public diagnostic facilities. ${ }^{12}$ By enforcing its patent rights in this way, GTG will be able to grow and undertake further biotechnology research and development. To a certain extent, these are precisely the types of actions that the Federal Government is promoting. But at the same time the impact on other sectors of the Australian biotechnology industry also needs to be considered, particularly the research and diagnostics sectors. If licence fees are too high or if licence terms are too restrictive this may have a detrimental effect on the capacity of Australian research institutions to carry out their research programs and on the capacity of diagnostic facilities to continue to offer diagnostic tests.

The GTG example provides a snapshot of the complex issues involved in finding the right balance in protecting the rights of both the holders and the users of patented technology. It is only when we have an understanding of how the industry is operating and the true extent of the social benefits and costs associated with patent system as it currently exists that we can assess whether the existing balance is appropriate. It is only then that we can fully evaluate the need for law reform and the most appropriate ways for reforming the law.

\section{MEDICAL BIOTECHNOLOGY RESEARCH IN AUSTRALIA}

In 1999 a major review of health and medical research in Australia was completed and published as The Virtuous Cycle - Working Together for Health and Medical Research (hereafter referred to as the Wills Review, after the Chair of the review committee, Mr Peter Wills). ${ }^{13}$ The Wills Review recognised Australia's proud tradition in health and medical research, citing figures that indicate that our research output is far in excess of what would be expected for the size of the Australian population. The Review pointed to the fact that increasing costs of health care will put extreme pressures on the economy in future and the important role of research in "determining the most cost effective and equitable approaches to both prevention

\footnotetext{
${ }^{12}$ See ABC Four Corners, above n7.

${ }^{13}$ Commonwealth of Australia, The Virtuous Cycle-Working Together for Health and Medical Research, Health and Medical Strategic Review, (Canberra: Australian Government Printing Service, 1999) (hereafter the Wills Review).
} 
and treatment" ${ }^{14}$ Particular emphasis was given to the need to take advantage of advances in biotechnology ("the industry of the $21^{\text {st }}$ century") to improve the health of the Australian population, to build the economy and to create valuable jobs. ${ }^{15}$ The review recognised that this window of opportunity would close given the pace of change unless Australia acts now.

A mutually reinforcing set of actions by the research sector, industry and government, a Virtuous Cycle, was described in the Wills Review as forming the framework for the development of biotechnology in Australia, with the research sector being the driving force. The Review recognised that there is a need for reform in the research sector, particularly in relation to:

- the scope, size and duration of research grants;

- the management of research enterprises and of research itself;

- the need for creation of better career opportunities in the research sector; and

- the need for priority driven research.

With regard to the company sector, the Review referred to the need to enhance technology transfer between research and industry and the need to stimulate flow of medium to long term venture capital. The Review also recognised the need for the government sector to increase and better manage its investment in health and medical research.

One of the outcomes of the Wills Review has been an increase in funding by the Federal Government to the National Health and Medical Research Council (the NHMRC). In its May 1999 budget the Government announced additional funding to the NHMRC of AU\$614 million over six years, together with other specific grants. ${ }^{16}$ Since then, other substantial public funding commitments have been made in this area of research. For example, Australian stem cell research efforts were boosted by the establishment of a National Stem Cell Centre in May 2003, and the award of AU\$46.5 million over five

\footnotetext{
${ }^{14}$ Ibid at 1.

${ }^{15}$ Ibid.

${ }^{16}$ Listed in Prime Minister's Science, Engineering and Innovation Council Third Meeting Background Paper, Innovation in Medical Biotechnology (1999) at 3, available at: http://www.dest.gov.au/science/pmseic/meetings/3rdmeeting.htm (accessed 3 June 2003).
} 
years through a joint funding arrangement between Biotechnology Australia and the Australian Research Council. ${ }^{17}$ The Centre is a collaborative arrangement between research institutions in Victoria, Queensland, New South Wales, South Australia and the Australian Capital Territory.

At the same time there is deliberate government policy in Australia, as in many countries with active biotechnology research programs, to encourage collaborations between the public and private sectors. Examples of relevant incentives in Australia include the Biotechnology Innovation Fund, the Innovation Investment Fund, Research and Development start up programs and Research and Development tax concessions. ${ }^{18}$ These incentives are part of a more general plan by the Federal Government to encourage greater levels of collaboration between the public and private sectors. One of the ways that it is doing this is by funding Cooperative Research Centres (CRCs) in innovative areas of technology. There are a number of CRCs in the area of medical biotechnology research.

These incentives serve the dual goals of providing further financial assistance to the upstream research effort and also providing a useful avenue for downstream transfer of technology. Traditionally, upstream research has been the province of the public sector and the private sector has focused more on the downstream application of that research. However, the merging of basic science and applied technology has been well documented, particularly in the area of biotechnology. ${ }^{19}$ The result, according to Rebecca Eisenberg and Richard Nelson, has been the formation of a significant private industry around pre-product development research. ${ }^{20}$ One of the key features of the research drive in the biomedical area is the

\footnotetext{
${ }^{17}$ Details are available on the Australian Research Council's website at http://www.arc.gov.au/grant_programs/centre_stem.htm (accessed 3 June 2003); also see http://backingaus.innovation.gov.au/research/bio_ce.htm (accessed 3 June 2003).

18 For details of these incentives, see the Australian Law Reform Commission, Issues Paper 27 Gene Patenting and Human Health (2003) at 73-75, available at: http://www.austlii.edu.au/au/other/alrc/publications/issues/27/ $\quad$ (accessed 19 November 2003) (hereafter ALRC).

19 See particularly R. Eisenberg and R. Nelson, 'Public vs. Proprietary Science: a Fruitful Tension?’ (2002) 77 Academic Medicine 1392; see also D. Chalmers and D. Nicol, 'Commercialisation of Biotechnology: Public Trust and Research' International Journal of Biotechnology, forthcoming.

${ }^{20}$ Eisenberg and Nelson, ibid.
} 
development of partnerships and collaborations between the public and private sectors.

The nature of biomedical research is that it is conducted on a cumulative basis: much basic research forms the foundation for later research and there are many steps between initial pioneering research and what consumers would consider to be end products. Different stakeholders conduct research at each stage of the research spectrum, developing products, methods or technologies that can be characterised as inputs into subsequent steps in the development of drugs, therapies, and diagnostic methods. The situation is complicated by the fact that patents are being granted on inventions at each stage of the development pipeline. Researchers developing more downstream products will require access to patents at the upstream end of the drug development continuum in order to conduct research and commercialise products. Access to many patents may be required in order to enable development of one product. Companies and researchers using these patents see them as being useful inputs into further research. However companies and researchers operating primarily upstream no doubt view the products they develop as valuable end products rather than research tools. ${ }^{21}$

After conducting a study of the industry in Australia in 2002, Hopper and Thorburn noted that the growth of the industry in Australia has slowed somewhat. ${ }^{22}$ They did, however, report a marked increase in companies that could be categorized as upstream, and that engage in the business of supplying more downstream users with, for example, gene sequence data. ${ }^{23}$ This apparent shift in focus by the Australian industry may have the effect of bolstering the upstream segment of the industry, and this will necessarily entail an increasing reliance on patent protection in this industry sector. Participants in the Australian industry will need to ensure:

\footnotetext{
${ }^{21}$ R.S. Eisenberg, 'Bargaining Over the Transfer of Proprietary Research Tools: Is This Market Failing or Emerging?’ in R.C. Dreyfuss, D.L. Zimmerman and H. First (eds.), Expanding the Boundaries of Intellectual Property: Innovation Policy for the Knowledge Society, (Oxford: Oxford University Press, 2001), at 228-229 (hereafter Eisenberg 2001).

${ }^{22}$ K. Hopper and L. Thorburn, 2002 BioIndustry Review - Australia \& New Zealand, (Canberra: Aoris Nova and Advance Consulting \& Evaluation, 2002) (hereafter Hopper and Thorburn).

${ }^{23}$ Ibid at 11.
} 
- that they obtain adequate intellectual property protection, particularly in the world's major markets; ${ }^{24}$ and

- that they make efforts to ensure that their intellectual property is marketable and adequately exploited.

\section{OTHER EMPIRICAL STUDIES}

This study was conducted in order to address a number of questions pertinent to the Australian medical biotechnology industry. A number of studies have been conducted in overseas jurisdictions in order to ascertain whether issues perceived to be a problem in the biotechnology and pharmaceutical industries are eventuating in practice. To date, no comprehensive study has been conducted in Australia examining these issues. Particular challenges facing the Australian industry make these issues relevant, and a number of other issues may confront the industry. ${ }^{25}$ We have identified these challenges as being:

- the need for Australian companies to seek foreign investment and enter into alliance activity with international companies; and

- the fact that most Australian patents falling into the biotechnology category are owned by foreign companies, necessitating the need for Australian companies to negotiate access deals with these companies. ${ }^{26}$

The impact of gene patenting and licensing on the development of the Australian biotechnology industry has not yet been assessed, although there is now some recognition of the need for examination of these issues. During the course of conducting this study, the Australian Law Reform Commission announced that they had received a reference to inquire into Gene Patenting and Human Health in Australia. ${ }^{27}$ The inquiry is considering a range of important issues associated with patenting and licensing practices.

Most recently, John Walsh, Ashish Arora and Wesley Cohen were commissioned by the United States National Academies of Sciences

\footnotetext{
${ }^{24}$ Ibid at 30.

${ }^{25}$ See Nicol and Nielsen, above $\mathrm{n} 4$.

${ }^{26}$ Nicol and Nielsen, above $n 4$ at 374.

${ }^{27}$ See generally, ALRC, above n18.
} 
to research licensing breakdowns within the biomedical industry in the United States. ${ }^{28}$ Walsh, Arora and Cohen set out to investigate two related questions: first, whether there was any evidence of an anticommons effect within the industry and on academic research, ${ }^{29}$ and secondly, whether there were any restrictions on access to patents over inventions or research tools that are foundational to future research. ${ }^{30}$ As Walsh, Arora and Cohen point out, these issues are real in a number of industries. ${ }^{31}$

The methodology employed by Walsh, Arora and Cohen entailed interviewing respondents within various sectors of the industry. Seventy interviews were conducted with respondents from biotechnology and pharmaceutical companies, universities, law firms, government and trade associations. ${ }^{32}$ Questions asked during interviews were aimed at exploring the issues outlined above. ${ }^{33}$ The questions also focused on how negotiations over intellectual property rights have changed over time, and strategies employed by researchers and companies to overcome any challenges brought about by intellectual property. ${ }^{34}$

Some leading researchers on behalf of the Max Planck Institute for Foreign and International Patent, Copyright and Competition Law, and the German Federal Ministry of Education and Research conducted a similar study. ${ }^{35}$ The authors conducted approximately 25 interviews with a view to identifying trends and developments within the German biotechnology and pharmaceutical industries. A broad range of issues were canvassed, including the nature of collaborations

${ }^{28}$ J. Walsh, A. Arora and W. Cohen 'Effects of Research Tool Patenting and Licensing on Biomedical Innovation' in W.M. Cohen and S.A. Merrill (eds.), Patents in the Knowledge-Based Economy (Washington: National Academies Press, 2003) at 287, available at:

http://books.nap.edu/books/0309086361/html/285.html\#pagetop (accessed 3 October 2003) (hereafter Walsh, Arora and Cohen); see also J.P. Walsh, A. Arora and W.M. Cohen, 'Working Through the Patent Problem', (2003) 299 Science 1021.

${ }^{29}$ See Context Chapter 4 for an explanation of the anticommons doctrine.

${ }^{30}$ See Context Chapter 4.

${ }^{31}$ Walsh, Arora and Cohen, above n28 at 7-8.

${ }^{32}$ Ibid at 8-9. See their Table 1 at 62 for a breakdown of the respondents by organisation and occupation.

${ }^{33}$ Ibid at 9.

${ }^{34}$ Ibid.

35 J. Straus, H. Holzapfel and M. Lindenmeir, Empirical Survey on Genetic Invention and Patent Law, (Munich: 2002 ) copy on file with authors (hereafter Straus, Holzapfel and Lindenmeir). 
within the industry, the availability of licensing, the effect of patenting on publication, infringement of genetic inventions, the quality of patent documents and the necessity for special protection for particular genetic inventions. ${ }^{36}$

The United States National Institutes of Health also established a Working Group on Research Tools to investigate access issues encountered by NIH funded investigators, and to investigate possible responses to any issues that arose. Again, the inquiry was conducted through a series of interviews, and in 1998 the Working Group presented a Report detailing their findings and recommendations. ${ }^{37} \mathrm{At}$ the same time they released a set of guidelines for the transfer of research tools within NIH funded research, acceptance of which has been somewhat guarded. ${ }^{38}$ The Working Group's inquiry had limited scope in that it was restricted to issues associated with access to research tools in transactions involving NIH grantees. At the same time, they recognised the issues they canvassed had broader application which were beyond the charge of the Working Group. The Working Group interviewed bench scientists, university technology transfer professionals, and personnel from private companies.

Concern over the patenting of gene sequences and other products of biological systems prompted the Organisation for Economic Cooperation and Development (OECD) to hold a workshop investigating the impact of patenting and licensing practices on access to genetic technologies, with over 100 invited speakers and participants reviewing empirical evidence on these issues. ${ }^{39}$ The Nuffield Council on Bioethics also released a discussion paper on the ethics of patenting DNA after extensively consulting core stakeholders within the United Kingdom industry. ${ }^{40}$

\footnotetext{
${ }^{36}$ A summary of the results is contained at I-II in Straus, Holzapfel and Lindenmeir, ibid.

${ }^{37}$ National Institutes of Health, Report of the National Institutes of Health Working Group on Research Tools (1998), available at: http://www.nih.gov./news/researchtools/index.htm (accessed 3 October 2002) (hereafter NIH).

38 National Institutes of Health (NIH), Basic Guidelines for the Transfer of Research Tools To and From Recipients of NIH Funds, Appendix A, NIH, ibid.

${ }^{39}$ See Organisation for Economic Co-operation and Development (OECD), Genetic Inventions, Intellectual Property Rights and Licensing Practices: Evidence and Policies, (Berlin: OECD, 2002), available at: http://www.oecd.org/dataoecd/42/21/2491084.pdf (accessed 18 November 2003) (hereafter OECD).

${ }^{40}$ Nuffield Council on Bioethics, The Ethics of Patenting DNA: A Discussion Paper, (London: Nuffield Council on Bioethics), available at:
} 
Prior to that, the United States National Academies of Science held a workshop on intellectual property rights and the dissemination of research tools in molecular biology. The workshop heard from a variety of participants within the various sectors of the industry, and a summary of the workshop was subsequently collated and published. ${ }^{41}$ Another study investigating the differences in levels of DNA patenting and licensing within the various industry sectors has also been conducted, ${ }^{42}$ while the effect of patents on the provision of clinical services was considered in a number of related studies. ${ }^{43}$

This study was conducted with the particular challenges facing the Australian industry in mind. This Report will generally consider the issues raised in the studies outlined above. Our initial focus when commencing the study was an analysis of whether there is any evidence of restricted access to upstream patents having a consequent effect on downstream research in Australia, and whether there is any evidence of an "anticommons" within the Australian medical biotechnology industry. The focus of the study became broader as we became aware of specific issues facing the industry after collecting survey evidence.

http://www.nuffieldbioethics.org/patentingdna/index.asp (accessed 18 November 2003) (hereafter Nuffield).

${ }^{41}$ National Research Council (NRC), Intellectual Property Rights and Research Tools in Molecular Biology (Washington DC: National Academy of Sciences, 1997) (hereafter NRC).

${ }^{42}$ M.R. Henry, M.K. Cho, M.A. Weaver and J.F. Merz, 'DNA Patenting and Licensing’ (2002) 297 Science 1279 (hereafter Henry and others). Some empirical evidence has also been collected in other studies. For example, the authors of a study considering the effect of Canadian agricultural biotechnology patent policy on the enhancement of social welfare, conducted a survey of research institutions in Canada, the US and Australia; see D. Dierker and P. Phillips, 'The Search For the Holy Grail? Maximising Social Welfare Under Canadian Biotechnology Patent Policy' (2003) 6 IP Strategy Today.

${ }^{43}$ J.F. Merz, D.G. Kriss, D.D.G. Leonard and M.K. Cho, 'Diagnostic Testing Fails the Test' (2002) 415 Nature 577 (hereafter Merz and others). See also M.K. Cho and J.F. Merz, 'Letter to Nature' (1997) 390 Nature 221; M. Cho, 'Impact of Patents on Provision of Clinical Genetic Testing Services' (2002) Paper Presented at OECD Workshop on Genetic Inventions, Intellectual Property Rights and Licensing Practices, January 24, 2002, Berlin. 


\section{CONTEXT CHAPTER 3: PATENTING OF BIOTECHNOLOGY INVENTIONS IN AUSTRALIA}

Australia, like any other member of the World Trade Organisation (WTO) is obliged to make patents available for all inventions in all fields of technology, provided that they fulfil the requirements of novelty, inventive step and industrial applicability (the invention requirements), as provided in Article 27 of the Agreement on Trade Related Aspects of Intellectual Property (TRIPS). ${ }^{44}$ Article 29 of TRIPS further states that members must require that the invention be fully described, including the best method of performing it (the disclosure requirements). Slight modifications were made to Australian patent law through the Patents (World Trade Organisation Amendments) Act 1994 (Cth) to achieve TRIPS compliance. Despite these prescriptions in TRIPS, there is considerable variability between countries both in the substantive law relating to the patentability of biotechnology inventions and in the procedural law prescribing the mechanisms for obtaining and maintaining patents. The key features of Australian patent law are discussed briefly below to assist those readers who are unfamiliar with these issues.

\section{PATENTABILITY REQUIREMENTS}

The requirements for obtaining Australian patent are provided for in section 18(1) (the invention requirements) and section 40 (the disclosure requirements) of the Australian Patents Act 1990 (Cth).

\footnotetext{
${ }^{44}$ In full, the Agreement on Trade-related Aspects of Intellectual Property Rights, Annex 1C in the Final Act Embodying the Results of the Uruguay Round of Multilateral Trade Negotiations, (1994) 33 ILM 81.
} 


\section{Section 18 Patentable inventions}

Patentable inventions for the purposes of a standard patent: $^{45}$

(1) Subject to subsection (2), ${ }^{46}$ an invention is a patentable invention for the purposes of a standard patent if the invention, so far as claimed in any claim:

(a) is a manner of manufacture within the meaning of section 6 of the Statute of Monopolies; and

(b) when compared with the prior art base as it existed before the priority date of that claim:

(i) is novel; and

(ii) involves an inventive step; and

(c) is useful; and

(d) was not secretly used in the patent area before the priority date of that claim by, or on behalf of, or with the authority of, the patentee or nominated person or the patentee's or nominated person's predecessor in title to the invention.

\section{Section 40 Specifications}

(1) A provisional specification must describe the invention.

(2) A complete specification must:

(a) describe the invention fully, including the best method known to the applicant of performing the invention; and

(b) where it relates to an application for a standard patent-end with a claim or claims defining the invention; and

(c) where it relates to an application for an innovation patent - end with at least one and no more than 5 claims.

\footnotetext{
45 The requirements for innovation patents, new type of patents which have a lower inventive threshold and shorter duration, are provided for in section 18(1A).

${ }^{46}$ Subsection (2) provides that human beings, and the biological processes for their generation, are not patentable inventions.
} 
(3) The claim or claims must be clear and succinct and fairly based on the matter described in the specification.

(4) The claim or claims must relate to one invention only.

The key features of these requirements are summarised below.

\section{The invention requirement: manner of manufacture and exclusions from patenting}

Australian patent law still uses the same language of 'manner of manufacture' as used in early English patent legislation: section 6 of the Statute of Monopolies 1623. Despite its antiquity, recent reports considering reform of Australian patent law recognise that this requirement has served its purpose well and should remain as the touchstone of patentability. ${ }^{47}$ The seminal case in interpreting this requirement is National Research and Development Corporation $v$ Commissioner for Patents (NRDC) ${ }^{48}$ In that case, the High Court set down the key considerations that were required to be satisfied: the claimed invention must belong to the useful rather than the fine arts; it must provide a material advantage; and its value to the country must be in the field of economic endeavour. ${ }^{49}$

The case law interpreting the manner of manufacture test recognises a range of exceptions for material that is considered to be unpatentable because it fails to satisfy this test. The two most relevant exclusions are discussed below.

\section{Discoveries/ products of nature}

Traditionally, mere discoveries have not been patentable because of the requirement that knowledge and ingenuity are used to produce a new and useful thing. ${ }^{50}$ Discoveries are neither new nor useful, first, because they are already in existence, and secondly, because they do not have the requisite applicability. In the NRDC case, the High Court

\footnotetext{
${ }^{47}$ Industrial Property Advisory Committee, Patents, Innovation and Competition in Australia (Canberra: AGPS, 1984). Intellectual Property and Competition Review Committee Review of Intellectual Property Legislation under the Competition Principles Agreement Final Report (Canberra: AGPS, 2000) (hereafter IPCRC).

${ }^{48}$ National Research and Development Corporation $v$ Commissioner of Patents (1959) 102 CLR 252 (hereafter NRDC).

${ }^{49}$ Ibid at 275.

${ }^{50}$ See, for example, Lane-Fox $v$ Kensington \& Knightsbridge Electric Lighting Co Ltd [1892] RPC 413.
} 
explicitly recognised the difficulty in distinguishing between discoveries and inventions. ${ }^{51}$ Products of nature have been considered to be one of the traditional exclusions from patenting on the basis that products of nature are already in existence and generally do not have the requisite industrial applicability.

The ground breaking United States case of Diamond $v$ Chakrabarty, ${ }^{52}$ allowing a patent for a modified bacterium, decided by the United States Supreme Court in 1980, laid the foundation for a growing body of case law and patent office decisions supporting the view that biological material is patentable. ${ }^{53}$ The list includes both whole organisms - bacteria and viruses and genetically modified higher organisms - and their components: genes, proteins, cell lines, and so on. Provided they are isolated and synthetically reproduced, they are classified as inventions, not discoveries. The European Biotechnology Directive confirms that this interpretation also applies in Europe. For example, Article 5.2 states that:

An element isolated from the human body or otherwise produced by means of a technical process, including the sequence or partial sequence of a gene, may constitute a patentable invention, even if the structure of that element is identical to that of a natural element.

On this basis, isolated and synthetically produced genes are patentable provided that they are novel, have an inventive step, and have some disclosed industrial applicability or utility. The Australian Patent Office similarly considers that patent protection is available for:

The building blocks of living matter, such as DNA and genes (including human DNA and genes) which have for the first time been identified and copied from their

\footnotetext{
${ }^{51}$ NRDC, above $n 48$ at 264.

52206 USPQ 193 (1980).

${ }^{53}$ In Australia, Diamond $v$ Chakrabarty was referred to with approval by the High Court in Grain Pool of Western Australia v The Commonwealth (2000) 46 IPR 515. See particularly paragraphs 46 and 47 of the majority judgment and paragraph 134 of Justice Kirby's judgment. Paragraphs 46 and 47 of the majority judgment could be read as referring only to the applicability of Chakrabarty in US law, or could be read more broadly, applying in Australian law as well. See M. Rimmer, 'Franklin Barley: Patent Law and Plant Breeders' Rights' (2003) 10(4) Murdoch Electronic Law Journal available at:

http://www.murdoch.edu.au/elaw (forthcoming).
} 
natural source and then manufactured synthetically as unique materials with a definite industrial use. ${ }^{54}$

One of the interesting features of the situation in Australia is that despite a large body of case law interpreting patent legislation generally and despite a growing body of jurisprudence in other countries on the application of patent legislation specifically dealing with biotechnology inventions, there is a dearth of biotechnologyrelated case law here. There has been one major Federal Court case, Genetics Institute $v$ Kirin Amgen, ${ }^{55}$ the primary focus of which was on the interpretation of the description requirements in section 40 . There have been a number of relevant decisions by the Commissioner of Patents, ${ }^{56}$ but the absence of judicial guidance in this area is problematic.

Methods of treatment of humans and animals

Article 27(3)(a) of the TRIPS Agreement expressly allows for the exclusion of diagnostic, therapeutic and surgical methods of treating humans and animals. Methods of human treatment have been described as unpatentable in a number of Australian cases, including NRDC. ${ }^{57}$ However, this exclusion was not expressly incorporated into the 1990 Patents Act and consequently its ongoing existence in modern Australian patent law has been subject to some debate. The matter was finally resolved in the case of Bristol Myers Squibb v FH Faulding \& Co $L t d^{58}$ where the Full Court of the Federal Court unanimously decided that there is nothing inherently unpatentable about methods of treatment. Black CJ and Lehane J referred to two compelling considerations in support of this conclusion:

\footnotetext{
${ }^{54}$ IP Australia, Australian Patents for: Microorganisms; Cell Lines; Hybridomas; Related Biological Materials and Their Use; and Genetically Manipulated Organisms (Canberra: AGPS, 1998), available at:

http://www.ipaustralia.gov.au/pdfs/patents/specific/biotech.pdf $\quad$ (accessed 20 November 2003) (hereafter IP Australia)

${ }^{55}$ Genetics Institute Inc v Kirin Amgen Inc (No 3) (1998) 156 ALR 30.

56 The Commissioner of Patents hears opposition proceedings, although the Commissioner's decisions can be appealed to the Federal Court. See the helpful analysis of some of these decisions by C. Lawson and C. Pickering, 'Patenting Genetic Materials - Failing to Reflect the Value of Variation in DNA, RNA and Amino Acids' (2000) 11 Australian Intellectual Property Journal 69 (hereafter Lawson and Pickering).

${ }^{57}$ These cases are reviewed in D. Nicol, 'Should Human Genes Be Patentable under Australian Law' (1996) 3 Journal of Law and Medicine 231 at 239-241.

${ }^{58}$ Bristol Myers Squibb v FH Faulding \& Co Ltd (2000) 46 IPR 553.
} 
1. the 'insurmountable problem, from a public policy viewpoint' of distinguishing between methods and products involved in treatment of the human body; and

2. the failure of Parliament to deal with this issue when it enacted the 1990 Act. $^{59}$

\section{Statutory exclusions from patenting}

There are a very limited number of express exclusions from patenting in the Australian Patents Act.

Human Beings and the Biological Processes for Their Generation Section 18(2) Patents Act 1990 states that human beings, and the biological processes for their generation, are not patentable inventions. This provision has some interesting history to it. In 1990 during the parliamentary debate of the Patents Bill Senator Coulter sought to add an amendment to section 18 that would effectively have excluded gene patents, whether naturally produced or chemically synthesised, as well as genetically engineered organisms. The Coulter amendment was rejected by the Senate Standing Committee on Industry, Science and Technology and by the Opposition. ${ }^{60}$ In the second reading speech of the Patents Bill Mr. Prosser said that the amendment was too restrictive because it would prevent patenting of vaccines and antibiotics and would create a flow on effect of hindering research and development of new technology in the medical and pharmaceutical fields. ${ }^{61}$

In the alternative, the present section 18(2) was introduced into the Patents Bill by Senator Harradine, and agreed to by both Houses. Senator Harradine stated his belief that the second half of this amendment would prevent patenting of techniques developed for cloning human embryos at the four cell stage, although Senator Coulter seemed to doubt that it would cover anything more than normal sexual reproduction. Reference to the possible patenting of humans in the first part of the amendment is generally considered to

\footnotetext{
${ }^{59}$ Ibid at 558.

60 Senate, Hansard Parliamentary Debates 20 September 1990, 2653; House of Representatives, Hansard Parliamentary Debates 16 October 1990, 2947.

${ }^{61}$ House of Representatives, Hansard Parliamentary Debates 16 October 1990, 2947, at 2948.
} 
be so contrary to fundamental norms that it goes without saying. This amendment therefore has limited effect. ${ }^{62}$

Discretionary refusal to accept applications

Section 51 of the Patents Act 1990 gives the Commissioner For Patents a number of discretionary grounds to refuse patents, including when the use of the invention would be contrary to law; for mere admixtures of known ingredients and where a claim includes the name of a person as the name, or part of the name, of the invention.

Exclusion of plants and animals for the purposes of an innovation patent

Section 18 (1A), (3) and (4) of the Patents Act 1990 excludes applications for innovation patents (but not for standard patents) for plants and animals and biological processes for the generation of plants and animals (but not microbiological processes). These exclusions are allowable under Article 27(3)(b) of TRIPS provided that there is plant protection under plant variety legislation, which is the case in Australia under the Plant Breeders Rights Act 1994 (Cth).

Attempt to exclude genes and gene sequences

Two attempts have been made to exclude gene sequences from patenting in Australia. The first was made by Senator Coulter discussed above. In June 1996 Senator Stott-Despoja of the Australian Democrats introduced an amendment to section 18 as a private member's bill. It would have added a new subsection to section 18 which would state that:

The following are not to be regarded as possessing the quality of novelty or inventiveness for the purposes of this section:

(a) naturally occurring genes; or

(b) naturally occurring gene sequences; or

\footnotetext{
${ }^{62}$ For a discussion of the applicability of this exclusion to stem cell technology see M. Rimmer, 'The Attack of the Clones: Patent Law and Stem Cell Research' (2003) 10 Journal of Law and Medicine 488 (hereafter Rimmer, Clone paper). Note that, at the time of writing, a Bill that would similarly prohibit the issuance of patents on human organisms (providing for codification of existing United States Patent and Trademark Office practice) is being debated in the United States Senate. See J. Abrams 'Lawmakers Weigh Human Organism Patent Ban' Washington Post 26 November 2003. Available at: http://www.washingtonpost.com/ac2/wp-dyn/A16205-2003Nov26 (accessed 8 December 2003).
} 
(c) descriptions of the base sequence of a naturally occurring gene or a naturally occurring gene sequence.

In the second reading speech on 27th June 1996 Senator StottDespoja commented on the need for urgent action, both in terms of public policy and also for fundamental philosophical and moral reasons. ${ }^{63}$ However, debate on the Bill was postponed and ultimately it lapsed.

Statute of Monopolies exclusions

Section 6 of the Statute of Monopolies does not allow letters patents for manners of new manufacture that are:

- contrary to law; or

- mischievous to the state by raising prices or harming trade; or

- generally inconvenient.

The contrary to law exclusion is expressly incorporated as a discretionary consideration through section 51(1)(a). Furthermore, it would appear to be accepted by the judiciary that the 1990 Patents Act and its predecessor, the 1952 Act, import the whole of section $6 .^{64}$

The general inconvenience exclusion has been used a number of times in Australia to deny patent claims for subject matter to which the public expect that they have free access. ${ }^{65}$ It could be argued that general inconvenience also allows for the introduction of ethical and public policy considerations into the patent process. ${ }^{66}$ However, to date the judiciary has been reluctant to employ this tool, preferring to leave controversial exclusions for Parliament to deal with. The question then is whether there are ever likely to be sufficiently clear

\footnotetext{
${ }^{63}$ Senate, Hansard Parliamentary Debates 27 June 1996, 2332.

${ }^{64}$ See, for example, the first instance decision of Gummow $\mathrm{J}$ in Rescare Ltd $v$ Anaesthetic Supplies Pty Ltd (1993) 25 IPR 119.

${ }^{65}$ Including purchased computers (Telefon A/B LM Ericssons Application [1975] FSR 49), lunch boxes (Clayton Furniture Ltd's Application [1965] AOJP 2303) and picture frames (Boccari's Application [1967] AOJP 1380).

${ }^{66}$ In Joos v Commissioner of Patents (1972) 126 CLR 611, for instance, Barwick $\mathrm{CJ}$ referred to the method of medical treatment exclusion being based on public policy using the Statute of Monopolies language of being generally inconvenient, and Gummow J confirmed that the question should be framed in this way in Rescare Ltd v Anaesthetic Supplies Pty Ltd (1993) 25 IPR 119. See also M. Forsyth 'Biotechnology, Patents and Public Policy: A Proposal for Reform in Australia' (2000) 11 Australian Intellectual Property Journal 202.
} 
social policy arguments for the courts to be willing to invoke the proviso. Perhaps the debate about gene sequence patents is the most obvious.

The TRIPS agreement does allow for some consideration of social and moral issues. Article 27.2 provides that:

Members may exclude from patentability inventions, the prevention within their territory of the commercial exploitation of which is necessary to protect ordre public or morality, including to protect human, animal or plant life or health or to avoid serious prejudice to the environment, provided that such exclusion is not made merely because the exploitation is prohibited by their law.

European case law and the European Biotechnology Directive gives some guidance as to how this provision might be interpreted. Article 53(a) of the European Patent Convention and mirror State legislation provides for the "ordre public/morality" exclusion discussed above. The Relaxin $^{67}$ case indicates that this exclusion will only be successfully invoked in rare and extreme cases. Relaxin involved a patent application by the Howard Florey Institute in Australia concerning molecular cloning and characterisation of a gene sequence coding for human relaxin. The Opposition Division pointed out that the function of this provision is to ensure that patents are not granted for inventions which would universally be regarded as outrageous. As such, the Article will only be invoked in rare and extreme cases. The Division referred to EPO Guidelines, which state:

A fair test to apply is to consider whether it is probable that the public in general would regard the invention as so abhorrent that the grant of patent rights would be inconceivable.

In this case it was held that a patent claiming a human gene sequence did not satisfy this requirement.

The European Biotechnology Directive lists four types of technologies that this provision is intended to exclude: cloning of human beings, germline gene therapy and the like. Based on the

${ }^{67}$ [1995] OJEPO 388. 
Biotechnology Directive and the decided cases, the ordre public/morality provision in Europe is very limited in scope. Moreover, both the courts and patent offices have expressed reluctance to consider ethical or social policy issues on the basis that they have no particular expertise on these matters.

\section{The novelty and inventive step requirements}

Logically, patents are only available for new inventions. However, the mere fact that something was in existence prior to a patent being filed is not enough to destroy novelty. An enabling disclosure is required to destroy novelty. Australian patent law requires that challenges to novelty are made on the basis that prior art information disclosing all of the features of the invention has been made publicly available. Hence, the isolation and characterisation of a gene outside of its natural environment will make it novel because prior to this the gene sequence was not publicly available.

Inventive step (or non-obviousness) requires an analysis of the prior art (what has gone on before in the field - including what is generally known and what is written). The question is whether the teachings from the prior art make the invention obvious to an ordinary person skilled in the field. Arguably, the techniques used to isolate and characterise genes are now so routine that very little inventive ingenuity is required to describe a new gene. In particular, the use of computer technology has dramatically improved the ease and speed of gene identification.

In the United States, the inventive step requirement has been interpreted liberally. The focus is placed on the invention itself, not on the techniques for producing it. This means that the focus of inquiry for gene patents is whether the gene sequence is obvious, not whether the method used to obtain it was obvious to try. The United States courts have accepted that the redundancy of the genetic code means that until the claimed molecules are actually isolated and purified it would have been highly unlikely that a person skilled in the area could have contemplated what was obtained. In Europe, on the other hand, the focus is on whether the isolation of the gene was obvious. On this basis, in silico gene identification by computerised matching of unknown human gene sequences to homologous animal gene sequences would be obvious. ${ }^{68}$

\footnotetext{
${ }^{68}$ See Nuffield, above n40 at 29-30.
} 
Whilst the courts in Australia have not been given the opportunity to address this issue with respect to gene sequence patents, recent High Court authority suggests that the United States approach would be favoured in Australia. In the case of Aktiebolaget Hassel $v$ Alphapharm the High Court rejected the notion that obviousness is determined by considering whether or not something is "obvious to try", instead affirming that the relevant inquiry is whether the invention itself is obvious. ${ }^{69}$

In 2001 a number of amendments to the Australian Patents Act 1990 were passed by the Federal Parliament in the Patents Amendment Act 2001 (Cth). These amendments affect both the novelty and inventive step requirements. It is now harder to establish novelty and inventive step because prior acts done anywhere in the world may be looked at, as well as documents published anywhere in the world (previous provisions required only that acts done in Australia were considered). Furthermore, in considering the inventive step requirement, it is possible to look at a combination of common general knowledge (the knowledge possessed by experts in the field) together with more than one piece of additional information (previous provisions restricted consideration to the common general knowledge and a single piece of information, with limited extensions for two or more related documents). However, in this regard, the novelty requirement remains the same as previously, that is, only single acts or documents can be looked at, with the same limited extensions as for inventive step. Finally, in examining a patent, the patent examiner must be satisfied on the balance of probabilities that the invention is novel and inventive (previously if the examiner was uncertain that these requirements were met he or she had to give the applicant the benefit of doubt).

Subsequently, in 2002 an amendment was made to the Patent Regulations creating a grace period, allowing public disclosure of the invention by or with consent of the patent holder for a period of not more than 12 months before the filing date. A grace period also exists in the United States, which also allows publication by the patent holder up to 12 months prior to filing. However, not all countries have a grace period. Consequently IP Australia has cautioned against using the grace period as a general strategy, recommending that it should only be relied on where there is accidental disclosure.

\footnotetext{
${ }^{69}$ Aktiebolaget Hassle v Alphapharm Pty Ltd (2002-3) 56 IPR 129 para 41.
} 
Whilst these amendments inevitably increase the hurdles in obtaining patents, they are unlikely to significantly impede the patenting of biotechnological inventions in any general way.

\section{The industrial applicability requirement}

Industrial applicability requires that the invention has some commercial value. In Australia, this requirement is in part dealt with through the manner of manufacture test in section 18(1)(a) of the Patents Act 1990.

In the early 1990s, large number of patent applications were filed in the United States for fragments of gene sequences known as expressed sequence tags (ESTs). ${ }^{70}$ This led to a flurry of statements as to the patentability of partial sequences and sequences of unknown function. The common trend emerging around the world is that raw sequence data is not generally patentable because it fails to satisfy the industrial applicability requirement. In the United States, where industrial applicability is determined by the utility requirement, new utility guidelines require that patent applications demonstrate specific, substantial and credible utility of the claimed invention. ${ }^{71}$ This requirement will be met for gene sequence patents if the function of the sequence is disclosed. The European Biotechnology Directive ${ }^{72}$ states that industrial applicability for gene patents requires the applicant to specify which protein or part of a protein is produced by the sequence or what function it performs. Similarly, as noted above, the Australian Patent Office considers that patentable subject matter includes DNA and genes "which have for the first time been identified and copied from their natural source and then manufactured synthetically as unique materials with a definite industrial use". ${ }^{73}$ However, there is no express requirement for specific, substantial and credible utility to be demonstrated by the applicant for a patent.

\footnotetext{
${ }^{70}$ See, for example, R. Eisenberg, 'Genes, Patents and Product Development' (1992) 257 Science 903.

${ }^{71}$ See Guidelines for Examination of Patent Applications (2001) 66 Federal Regulations (US) 1092; Manual of Patent Examining Procedure, 8th ed., Feb 2003 revision (Washington, DC: United States Patent and Trademark Office, 2003); $\S 2107$, available at:

http://www.uspto.gov/web/offices/pac/mpep/index.html (accessed 5 September 2003) (hereafter US Examination Guidelines).

${ }^{72}$ Directive 98/44/EC On the Legal Protection of Biotechnological Inventions.

${ }^{73}$ IP Australia, above n54.
} 
In addition to the manner of manufacture requirement in Australia, there is a requirement that the invention is useful. However, this requirement is not assessed at examination. Usefulness in the sense used in the Australian legislation requires only that the invention does what it was intended to do, and the end in itself is useful. Commercial practicality or viability is not a necessary requirement, except that if a particular result is claimed, that result must be achievable. ${ }^{74}$ The issue, then, is not whether the invention is commercially viable, but whether the invention as claimed does or does not attain the result promised by the patent holder.

In a recent review of Australian patent law it was recommended that the manner of manufacture test should be retained, but that the Patent Office should adopt the examination practice of requiring specific, substantial and credible utility. ${ }^{75}$ No action has been taken in response to this recommendation to date.

\section{The disclosure requirement}

When a patent has been claimed for a particular product or process, patent rights extend to cover any uses of the product, even when the new uses are themselves novel and inventive and are not disclosed in the patent. Such new uses may be the subject of new patent claims, but they are said to be dependent on the original patent, because they cannot be performed without using that patent. As such, where a patent is granted for a gene sequence, the patent holder gets broad rights to control all subsequent uses of that gene sequence. In addition to this, the claims made in a patent application often go beyond the actual invention. For example, patent claims may extend to a broad range of species and a broad range of products. We discuss the issues associated with broad claims over genes and other foundational patents in depth in this Report, particularly in Results Chapters 4 and 5.

In Australia, the breadth of patent claims for biotechnology inventions was considered in Genetics Institute $v$ Kirin Amgen. ${ }^{76}$ The invention under consideration involved the use of recombinant DNA technology to produce commercial quantities of erythropoetin (EPO), an important and rare protein which plays a major role in regulating

\footnotetext{
${ }^{74}$ Rehm v Websters Security Systems (1988) 11 IPR 289, at 305; Rescare Ltd v Anaesthetic Supplies Pty Ltd (1993) 25 IPR 119, at 143.

${ }^{75}$ IPCRC above $n 47$.

${ }^{76}$ Above $n 55$.
} 
the rate of red blood cell formation. The main claim was for a purified and isolated polypeptide having the primary structural conformation and one or more of the biological properties of naturally occurring erythropoetin, unlimited by species or by specific structure. Heerey $\mathrm{J}$ held that the claim was permissibly wide because the gene sequence for EPO was a principle of general application and, therefore, it was acceptable for the claim to be made in correspondingly general terms.

The Genetics Institute decision signals that as a general rule broad claims to gene sequences and their products may be accepted in Australia when the method of isolating the full gene sequence is disclosed. In the circumstances, the elucidation of the EPO sequence was a major breakthrough. However, because sequencing is now much more routine and requires very little in the way of inventive skill, granting broad patent rights may be too great a reward for such endeavours.

In the United States, in contrast, there is much more reluctance by the judiciary to uphold broad patent claims. ${ }^{77}$ Furthermore, new written description and enablement guidelines impose similar restrictions on new claims. ${ }^{78}$

\section{Procedural matters}

There are two key procedural matters where Australian patent law coincides with European law but differs from United States law:

The first to file rule

In Australia and Europe the first person to file a patent for a particular invention has precedence, whereas in the United States the first to invent rule applies.

\section{Pre-grant opposition}

Section 59 of the Australian Patents Act 1990 enables a person to challenge the validity of a patent at any time during the three-month period after the patent has been accepted by the Patent Office. There is no provision for pre-grant opposition in United States patent law, although there is the option of bringing interference proceedings under section 135 of the United States patent legislation (35 U.S.C.).

\footnotetext{
${ }^{77}$ See, for example, Regents of the University of California v Eli Lilly \& Co (1997) 119 F3d 1159.

${ }^{78}$ See US Examination Guidleines, above n71.
} 
The function of interference proceedings is to determine priority based on the first to invent rule.

Section 59 of the Australian Patents Act 1990 allows only limited grounds upon which a patent can be opposed. For example opposition based on the invention requirements in section 18(1) is limited to manner of manufacture, novelty and inventive step. There are broader grounds for post-grant challenges to patent validity (revocation) as provided in section 138.

As noted in the ALRC Issues Paper, the pre-grant opposition procedure is seldom used (1.3 percent of accepted applications from 1997 to 2002). ${ }^{79}$ Nevertheless, it has been made use of to challenge some important biotechnology patent applications. ${ }^{80}$ For example, the CSIRO has opposition proceedings on foot in relation to patent applications claiming rights over RNA interference technology (also known as gene silencing), including an application filed by the Queensland-based biotechnology company Benitec Australia Ltd (application 199929163). ${ }^{81}$

\section{USE OF PATENTS}

Patents, like any other forms of property, have intrinsic value in that they can be bought and sold. However, the real value of patents is that they give the patent holder a period (usually 20 years) during which time they have the exclusive right to make use of the invention that underlies the patent. In this regard, patents are often said to give the patent holder a temporary monopoly.

\section{The right of exploitation}

Patent legislation prescribes the rights of the patent holder. Section 13 of the Patents Act 1990 (Cth), for example, provides that a patent gives the patent holder exclusive rights, during the term of the patent, to exploit the invention and to authorise another person to exploit the invention. The term "exploit” includes making, hiring, selling and

\footnotetext{
${ }^{79}$ ALRC, above n18 at 114.

${ }^{80}$ See Lawson and Pickering, above n56.

${ }^{81}$ See 'Benitec's core patents' available at:

http://www.benitec.com.au/about/core_patents.htm (accessed 3 September 2003).
} 
otherwise disposing of the invention. ${ }^{82}$ There are a few points that need to be made in relation to this definition.

First, it is often said that a patent actually gives the patent holder a negative right: the right to prevent others from exploiting the invention. If another person makes use of the invention without the permission of the patent holder, the patent holder has the right to sue for infringement. In terms of liability, it is irrelevant whether or not the person alleged to be infringing knew about the patent, although lack of knowledge is relevant when the court determines whether or not damages should be awarded. ${ }^{83}$ As such, a patent does not give the patent holder the absolute positive right to exploit an invention. Other legal and regulatory requirements have to be complied with. For example, the exploitation of pharmaceutical patents requires compliance with all of the detailed safety and efficacy requirements of the Therapeutic Goods Act 1989 (Cth). Hence, the right to exploit the invention is limited by other legal and regulatory requirements.

Secondly, although s 13 states that the patent holder has the right to exploit the invention, in fact, the patent holder has the right to exploit what has been claimed in the patent. It is often the case that the claims made in the patent are much broader than the true scope of the invention. This is particularly the case for gene patents, where variants of the gene sequence, gene products, diagnostic tests, and therapies all might be claimed, when the true scope of the invention is merely the disclosure of the gene sequence. We will consider this issue again later.

Thirdly, as previously mentioned, patent rights are like other property rights in that the patent holder is entitled to transfer ownership to any other person (assignment). They also enable the patent holder to give permission to another person to make use of those rights (licensing). There are various ways that patent rights can be licensed:

- a sole licence means that the patent holder retains their right to exploit the invention and gives one other person equivalent rights;

- an exclusive licence means that the patent holder hands over the right to exploit the invention to another person to the

\footnotetext{
${ }^{82}$ The definition of 'exploit' is contained in Schedule 1 of the Patents Act 1990 (Cth).

${ }^{83}$ Patents Act 1990 (Cth) section 123.
} 
exclusion of all other people, including the patent holder. In this regard, the only differences from sale are that there is no formal transfer of registration and that the licence is generally for a fixed period;

- a non-exclusive licence means that the patent holder gives to another person the right to exploit the invention, but this does not prevent the patent holder from exploiting the invention him or herself, or from licensing that right to others.

Patent licences may be limited to certain aspects of the invention. They may also be limited in duration, geography, quantum, or in various other matters. Payment by the licensee may be in the form of a single lump sum, periodic payments, a series of milestone payments triggered by a particular event (for example, approval to market a product in a particular country) and/or a royalty fee per product sale or use. Licences are contractual arrangements and are regulated by common law contractual principles. The focus of contract law is on the rights and obligations of individuals.

In analysing gene patents such as the BRCA patents, we have seen that claims are made to gene sequences, gene products, therapies, drugs and diagnostics. Patents that are cast in these terms effectively give the patent holder the exclusive right to control all downstream uses of the gene sequence, including commercial research and development of tests, therapies and drugs.

\section{Research exemption}

It is often said that the use of patented inventions in non-commercial research does not amount to infringement. However, the ambit of the so-called "research exemption" is far from clear. ${ }^{84}$ For example, there is no express provision for exemptions from infringement for acts done for non-commercial research purposes under existing Australian legislation or case law.

In the United States, a case law defence of experimental exemption from liability is available against patent infringement. However, this exemption has been read very narrowly. For example, in Roche

\footnotetext{
${ }^{84}$ For an excellent review of exemption from infringement for non-profit research see C. Nottenbaum, P.G. Pardey and B.D. Wright, 'Accessing Other People's Technology for Non-profit Research' (2002) 43 Australian Journal of Agricultural and Resource Economics 3.
} 
Products Inc v Bolar Pharmaceutical $\mathrm{Co}^{85}$ the court characterised the exemption as being "truly narrow". Although there was some indication in subsequent cases of a willingness to extend its ambit, ${ }^{86}$ the United States Court of Appeals for the Federal Circuit recently confirmed that the defence is very narrow and strictly limited. ${ }^{87}$ The Court followed a line of precedent limiting the defence to actions performed for "amusement, to satisfy idle curiosity, or for strictly philosophical inquiry." 88 This does not include use that is in any way commercial in nature or conduct that is "in keeping with the alleged infringer's legitimate business, regardless of commercial implications." 89 Consequently, a public research institution could not rely on the defence when a researcher uses a patented invention in a research project because it furthers that institution's legitimate business objectives. ${ }^{90}$

Exemption from infringement in Europe has a different basis. Patent legislation in a number of European countries provides express exemption from infringement for experimental purposes. In the United Kingdom, for example, section 60 of the Patents Act 1977 provides in subsection 5 that:

An act which, apart from this subsection, would constitute an infringement of a patent for an invention shall not do so if -

(a) it is done privately and for purposes which are not commercial;

(b) it is done for experimental purposes relating to the subject-matter of the invention;

...

The private use exemption has the same limitations as the United States case law exemption, being restricted to activities that have no possible commercial application. The experimental purpose exemption is, in one respect, potentially very broad in application,

\footnotetext{
${ }^{85} 733$ F 2d 858 (1984).

${ }^{86}$ R. Eisenberg 'Patents and the Progress of Science: Exclusive Rights and Experimental Use' (1989) 56 University of Chicago Law Review 1017, 1018-19.

${ }^{87}$ Madey v Duke University, 307 F 3d 1351, 1360-1 (Fed Cir, 2002) (hereafter Madey).

${ }^{88}$ Ibid at 1362.

${ }^{89}$ Ibid.

${ }^{90}$ Ibid.
} 
covering any experimentation on the invention (presumably including experimentation by commercial entities) as opposed to experimentation with the invention. In the other respect, however, it provides little comfort for non-commercial researchers who make use of the patented invention in their research. ${ }^{91}$

There is presently little indication that patent holders are generally enforcing their patent rights against academic researchers (the actions by Myriad and GTG discussed above in Context Chapter 2 being notable exceptions). If patent holders were to enforce their rights in any systematic way, much of the research conducted in the academic arena could at the very least become more expensive, through payment of licence fees, and more time consuming, because of the need for licence applications. At the worst, some research may actually be prevented if licensing were refused. For such reasons, there is some justification for an explicit research exemption in patent legislation to ensure that research having no commercial implications is not impeded. ${ }^{92}$ Difficulties will inevitably arise in setting the limits on the types of research that have no commercial implications.

\section{PATENT ACTIVITY IN AUSTRALIA}

There is little doubt that patent filing activity has increased dramatically in Australia, as it has in many other countries, over the last decade. We have previously reported on some key features of patent applications and grants in Australia from data supplied to us by IP Australia. ${ }^{93}$ The key data are extracted in the following summary. Up to 1998:

- of the 5 000-11 000 patents granted each year in Australia, only around 10 percent originate in Australia. United States inventors dominate, holding over 45 percent of the patents granted in 1996;

\footnotetext{
${ }^{91}$ For a useful summary of the case law interpreting these provisions see L. Bentley and B. Sherman, Intellectual Property Law (Oxford: Oxford University Press; 2001) at 506-508.

${ }^{92}$ Following Madey, above n87, there has also been some support for the adoption of an express exclusion in United States patent law. See T. Saunders, 'Renting Space on the Shoulders of Giants: Madey and the Future of the Experimental Use Doctrine’ (2003) 113 Yale Law Journal 261.

${ }^{93}$ Nicol and Nielsen, above $n 4$ at 361-362. The authors thank Jodi Lawler and Rod Crawford from IP Australia for providing this data.
} 
- of the 2000 or so patent applications filed in the biotechnology category, only around two percent originate in Australia; ${ }^{94}$

- in real terms the number of biotechnology patents filed by Australian residents increased from 26 in 1988 to 46 in 1998, showing that Australian biotechnology is in a growth phase.

Further data provided in IP Australia's annual reports indicates that the general rate of filing of patent applications continues to increase. Doubtless, the number of applications filed in the biotechnology category will have risen significantly over the last few years. However, it seems unlikely that the percentage originating in Australia will have changed dramatically. As such, it is probably fair to say that non-Australian companies and institutions hold most biotechnology patents granted in Australia. ${ }^{95}$

A Report commissioned by the Australian Research Council (ARC) and the CSIRO indicates that the number of Australian invented patents filed in the United States closely matches the number of Australian invented patents filed in Australia. ${ }^{96}$ During the five-year period 1994-1998 there was a 249 percent increase in Australian invented biotechnology patents from the previous five-year period, further supporting the conclusion that Australian biotechnology is in a growth phase. ${ }^{97}$ However, the number of biotechnology patents originating in Australia pales into insignificance when compared with the number originating in the United States. In particular, a number of gene sequencing companies have flooded the USPTO with applications for gene patents. For example, Incyte reported that in 2003 it has been granted 700 U.S. patents on gene transcripts and has pending patents on more than 27,000 other full-length human transcripts. $^{98}$

Aside from gene patents themselves, there has also been increasing patent activity in the area of research tool development.

\footnotetext{
${ }^{94}$ Note that the biotechnology category includes both medical and agricultural biotechnology. It also includes gene patents.

${ }^{95}$ See Nicol and Nielsen above $\mathrm{n} 4$ at 361-362.

${ }^{96}$ CHI Research Inc, Inventing Our Future: The Link Between Australian Patenting and Basic Science (Canberra: AGPS, 2000), at 29.

${ }^{97}$ Ibid at 32.

${ }^{98}$ See Incyte, Intellectual Property, available at: http://www.incyte.com/control/researchproducts/licensing (accessed 5 September 2003).
} 
Biotechnology research tools are the technological developments that enable particular lines of biotechnology research to be pursued. The term "research tools" can be defined either narrowly or broadly. A narrow definition would limit research tools to those technologies that are traditionally understood to comprise methodologies employed in research laboratories for identifying potential drugs, such as receptors and drug targets. ${ }^{99}$ Notable examples are recombinant DNA technology, PCR taq polymerase, and genes and receptors. A broad definition would encompass virtually all upstream and intermediate technologies that primarily constitute inputs into further research and are not in themselves 'end products' in the sense of products that will be available to end consumers. As well as the 'foundational' tools that would be encompassed in a narrow definition, examples might include genomics databases, combinatorial libraries, clones and transgenic mice.

Some of these research tools are more "foundational" than others. For example, taq polymerase is required for all DNA based research, and so limitations on the dissemination of this technology understandably attract considerable attention. Similarly, the technology claimed in the junk DNA patents mentioned in Context Chapter 2 is foundational to much modern genetics research, particularly research relating to the development of diagnostic tests. But agreeing upon commonalities in what constitutes a research tool is undoubtedly difficult. ${ }^{100}$ In writing this Report, we employed a fairly broad definition of research tools by classing any research input as a research tool. At the same time, we recognise that employing such a definition may be controversial in that virtually all of these research tools comprise important products of many research institutions and companies. It is not our intention to detract from this, but we are employing a definition that puts us in line with many of the other studies that have been conducted. ${ }^{101}$

There is increasing debate in the United States about the consequences of granting patents that claim broad rights over foundational technological developments. The potential consequences are discussed in more detail below, and the question of their applicability within the Australian context is important to much of our further analysis. A number of key foundational patents have been identified as being particularly likely to impact on future

\footnotetext{
${ }^{99}$ See OECD, above n39 at 50.

${ }^{100}$ See also NIH, above n37 at 4-5; Eisenberg (2001), above n21 at 229.

${ }^{101}$ See, for example, NIH, above n37 at 3-4; Walsh, Arora and Cohen, above n28; Cf Straus, Holzapfel and Lindenmeir, above n35 at I.
} 
biotechnology research. We have already mentioned the junk DNA patents and the BRCA patents. As a first step in our analysis, we conducted searches for other foundational patents in the United States and Australia to determine their status in the Australian context. We selected these patents because they have been listed as being particularly problematic in a number of other reports. ${ }^{102}$ Surprisingly, we found that in most cases a patent had not been filed in Australia, or, where one had been filed it had not been granted. Notable exceptions include patents claiming taq polymerase and junk DNA, both of which have already been mentioned above. Details of the results of our searches are presented below.

\section{Recombinant DNA technology}

Patent title: Biologically functional molecular chimeras Patents granted by United States Patent and Trademark Office (USPTO) in 1980 US4,237,224 and in 1988 US4,740,470 (now expired) Patent holder: Board of Trustees Stanford University

Australian status: no record found

Representing the most fundamental technology in molecular biology, recombinant DNA technology consists of one process patent for making molecular chimeras, and two product patents for proteins produced using recombinant DNA. This technology has no alternatives and is essential to all research in molecular biology. ${ }^{103}$ The patents were extremely broad but were widely licensed for low fees.

\section{CCR5 receptor}

Patent title: Human G-Protein Chemokine Receptor HDGNR10

Patent granted by USPTO in 2000 US6,025,154

\footnotetext{
102 See particularly Nuffield, above n40; Walsh, Arora and Cohen, ibid at 296-297 and 305-314; OECD above n39 at 12-13. Further information was kindly provided by John Walsh, personal communication 2 September 2003.

${ }^{103}$ See further NRC, above n41 at 40-42.
} 
Patent holder: Human Genome Sciences, Inc.

Australian status: application number 199526632 possibly lapsed.

The CCR5 receptor is a chemokine receptor. Human Genome Sciences isolated the gene that codes for the receptor and filed a patent claiming rights over the gene and the CCR5 protein product. Although their claims over the protein product covered a viral receptor, they were unaware at the time the patent was filed that the HIV virus enters cells through the CCR5 receptor. Subsequent research by the NIH revealed this to be the case. ${ }^{104}$

\section{Human embryonic stem cell technology}

1. Patent title: Primate embryonic stem cells Patent granted by USPTO 2001 US6,200,806

Includes in claim 9 a method for isolating pluripotent embryonic stem cells.

2. Patent title: Hematopoietic differentiation of human pluripotent embryonic stem cells

Patent granted by USPTO in 2001 US6,280,718

Patent holder: Wisconsin Alumni Research Foundation (WARF)

Australian status: no record found in respect of these particular patents.

Note some of the other patents owned by WARF:

1. Title: Primate embryonic stem cells Patent granted by USPTO 1998 US5,843,780

2. Title: Method of making embryoid bodies from primate embryonic stem cells

Patent granted by USPTO in 2003US6,602,711

Australian status of equivalent or related WARF applications:

${ }^{104}$ See further Nuffield, above n40 at 41. 
1. Primate embryonic stem cells: application number 199647584;

2. Primate embryonic stem cells with compatible histocompatibility genes: application number 199938814;

3. Method of making embryoid bodies from primate embryonic stem cells: application number 200138491.

Human embryonic stem cells are an important tool in the development of therapeutics to treat disease. The cells can be developed into different tissue types. The central patent is for the isolation of human embryonic stem cells. Exclusive rights to develop the cells into a limited number of tissue types has been granted to Geron Corp, plus options for exclusive rights to develop the remaining tissue types. There has been a protracted licensing dispute between WARF and Geron Corp relating to this patent and other patents controlled by Geron Corp, particularly United States patent 6,090,622 'Human pluripotent germ cells'. 105

Note that in Australia a number of patent applications have been filed by Geron Corp relating to pluripotent embryonic stem cells and one (AU751321) has been granted.

\section{CD34}

Relevant patents:

1. Title: Human stem cells

Patent granted by USPTO 1987 US4,714,680

2. Title: Human stem cells and monoclonal antibodies

Patent granted by USPTO 1990 US4,965,204

3. Title: Human stem cells and monoclonal antibodies Patent granted by USPTO 1991 US5,035,994

4. Title: Human stem cells and monoclonal antibodies

${ }^{105}$ The inventor was John Gearhart of Johns Hopkins University. See G. McGee and E. Banger 'Ethical Issues in Patenting and Control of Stem Cell Research' in Magnus, Caplan and McGee (eds), Who Owns Life? (New York: Prometheus, 2002) at 253; also discussed by Walsh, Arora and Cohen, above n28 at 308-309. See also Rimmer, Clone paper, above n62. 
Patent granted by USPTO 1992 US5,130,144 ${ }^{106}$

Patent holder: Johns Hopkins University

Australian status: no record found

CD34 is an antigen found on stem cells, which are undifferentiated blood cells found in bone marrow. The United States patent was filed following the discovery of a particular antibody (My-10) that selectively binds to (and detects) CD34. All antibodies that bind to CD34 were claimed. The technology employing the binding of antibodies to CD34 was useful in the development of cancer therapies, specifically as an alternative to bone-marrow transplants.

\section{Cox-2}

Patent title: Method of inhibiting prostaglandin synthesis in a human host

Patent granted by USPTO in 2000 US6,048,850

Patent holder: University of Rochester

Australian status: no record found (note that other patents and patent applications relating to Cox-2 do exist).

This patent claims broad rights over the Cox-2 enzyme, and any compounds developed to inhibit the enzyme. It now appears that compounds developed to inhibit the enzyme may have broad applicability - in addition to one of these compounds being useful as a pain medicine, it may also have some anti-cancer properties. $^{107}$

\footnotetext{
${ }^{106}$ P. Mikhail, 'Hopkins v CellPro: An Illustration that Patenting and Exclusive Licensing of Fundamental Science is Not Always in the Public Interest' (2000) Harvard Journal of Law and Technology 375 at 385.

${ }^{107}$ See Walsh, Arora and Cohen, above n28 at 297. See also their n16 outlining the results of unsuccessful infringement proceedings brought by the University of Rochester against Searle \& Co Inc.
} 


\section{NF-KB messenger protein}

Patent title: Nuclear factors associated with transcriptional regulation

Patent granted by USPTO 2002 US6,410,516

Patent holder: Harvard College, MIT, Whitehead

Institute

Australian status: no record found

This is a broad patent covering methods for the treatment of diseases using the NF-KB messenger protein. NF-KB is widely known for its role in cell suicide. The patent has been exclusively licensed to Ariad Pharmaceuticals.

\section{Method of screening}

Relevant patents

1. Patent title: Method of screening for protein inhibitors and activators

Patent granted by USPTO 1990 US4,980,281

2. Patent title: Method of screening for protein inhibitors and activators

Patent granted by USPTO 1993 US5,266,464

3. Patent title: Method of screening for protein inhibitors and activators.

Patent granted by USPTO 1999 US5,877,007

Patent holder ICT Pharmaceuticals, Inc (now known as Housey Pharmaceuticals, Inc)

Australian status: application number 199064271 possibly lapsed

Note that there is a patent with the title: Method of screening for protein inhibitors and activators, granted in Australia AU612948 to Progenics Pharm, Inc.

These patents are broadly applicable to methods used to screen substances for active compounds for potential use as pharmaceuticals. The patents have been the 
subject of litigation in the United States. ${ }^{108}$ The implications of this litigation will be discussed in the Results Chapters.

\section{Cre-lox}

Patent title: Site specific recombination of DNA in eukaryotic cells.

Patent granted by USPTO 1990 US4,959,317

Patent holder: E.I. DuPont de Nemours and Co.

Australian status: a related patent has been granted to DuPont. Title: Site specific recombination of DNA in plant cells, AU639059.

This patent describes a method of using site specific recombination of DNA as a genetic engineering tool, particularly by inactivating known genes. After a number of years in which access to Cre-lox was restricted by DuPont, an agreement was signed between DuPont and the NIH in 1998 allowing noncommercial research use without a licence. However, transfer of Cre-lox mice requires entry into a Material Transfer Agreement on terms that restrict use. ${ }^{109}$

\section{PCR and Taq polymerase}

Patent title: purified thermostable enzyme Patent holder: Cetus Corp (assigned to F Hoffmann-La Roche AG)

Patent accepted in Australia AU632857 in 1996

\footnotetext{
108 See Bayer AG v Housey Pharmaceuticals, Inc 169 F. Supp. 2d 328 (D. Del. 2001) and Bayer AG v Housey Pharmaceuticals, Inc 228 F. Supp 2d 467 (D. Del 2002) (hereafter Housey cases).

109 See I. Abrams and M. Kaiser 'Licensing Transgenic Mice: a Short Tutorial (2000) 12 Journal of Association of University Technology Managers, available at: http://www.autm.net/pubs/journal/00/transgenicmice.html (accessed 22 October 2003).
} 
Opposition proceedings in 1997 by Bresagen Ltd and New England Biolabs: claims 1-7 invalid. ${ }^{110}$ The litigation relating to the opposition to this patent is still ongoing. 111

Polymerase chain reaction (PCR) enables specific and rapid amplification of existing DNA or RNA sequences in a test sample. Part of the process of PCR involves separating double stranded DNA using high temperatures. Taq polymerase is the enzyme used in the amplification, useful for its heat-resistant properties. ${ }^{112}$ Roche's attempts to broadly enforce its patents are well known in Australia and were referred to by a large number of participants in our study, as discussed in Part 2 of this Report.

\section{Oncomouse}

Patent title: transgenic non-human mammals

Patent granted by USPTO 1988 US4,736,866

Patent holder: President and Fellows of Harvard College

Australian status: no record found, although an application by Harvard College exists for B cell deficient transgenic non-human animals (application number AU 199187358)

Note also that Australian patents have been granted in respect of other transgenic non-human animals.

This patent describes the methodology for producing a non-human mammal with an increased propensity for developing cancer. It serves as an important research tool in cancer research. Equivalent patents have been the subject of prolonged litigation in Europe and

${ }^{110}$ F Hoffman-la Roche AG v Bresagen Ltd and New England Biolabs [1997] APO 57 (12 November 1997).

${ }^{111}$ See, for example, New England Biolabs, Inc v F Hoffman-la Roche [2003] FCA 1460 (4 November 2003).

${ }^{112}$ See further NRC, above n41 at 43-46. 
Canada. ${ }^{113}$ In the United States, Harvard has an exclusive licensing arrangement with DuPont which has caused considerable access difficulties for others, particularly universities undertaking industrysponsored research. ${ }^{114}$

\section{Hepatitis C virus (HCV)}

Chiron Corp has a suite of patents relating to HCV in a number of jurisdictions, including claims to the components of the virus itself and its use in diagnostic tests, vaccines and drug development. Chiron is widely known for aggressively enforcing its patents. Murex Ltd sought to have a Chiron patent revoked in Australia in the early 1990s. ${ }^{115}$ Although there were a number of interlocutory decisions in this matter ${ }^{116}$ and case went to hearing before Burchett J, it ultimately settled, with Chiron granting a licence to Murex.

These broad method claims and aggressive enforcement practices have created controversy in the biotechnology industry, particularly in the United States. A notable exception is recombinant DNA technology. This technology constitutes the cornerstone of modern biotechnology, and the patent contained very broad claims. If access to it had been in any way restricted, the impact on all avenues of current biotechnology practice would have been profound. ${ }^{117}$ The patent has been extensively licensed, and affordable licensing fees meant that access to the technology was available to anyone who

\footnotetext{
113 See, for example, Oncomouse T19/90 [1990] Official Journal of the European Patent Office 476; Harvard College v Canada (Commissioner of Patents) (2002) SCC 76.

${ }^{114}$ Discussed by Walsh, Arora and Cohen, above n28 at 307-308. There is ongoing concern in the United States about the restrictions on access to oncomouse technology being imposed by DuPont. See, for example, 'Cancer Scientists Contend DuPont Restricts Progress' (3 November 2003) The Los Angeles Times.

${ }^{115}$ Docket No. NG106 of 1994.

116 See, for example, Murex Diagnostics Australia Pty Ltd v Chiron Corporation [1995] FED No. 961/95; and Murex Diagnostics Australia Pty Ltd v Chiron Corporation (1995) 128 ALR 525.

${ }^{117}$ The patent is very broad, and if access had been restricted, its validity would no doubt have been challenged.
} 
required it. ${ }^{118}$ Broad patent claims and restrictive technology transfer policies are likely to inhibit research if follow-on innovators doubt they will be able to gain access to those patents. For example, the breadth of the Cox-2 inhibitor combined with aggressive enforcement of the patent may discourage other researchers from investigating various compounds that act on the enzyme.

We have established that a considerable number of these foundational research tool patents are not (or not yet) patented in Australia. This has implications for the Australian industry in that certain avenues of research may not be as restricted as they are in other jurisdictions. However, it should be noted that in a number of these cases other relevant patents do nevertheless exist, suggesting that these areas of research are not entirely free from encumbrances. Hence, we caution that it may not always be the case that the Australian industry is protected from the reach of broad, problematic research tool patents. In addition, it is clearly beyond the scope of this study to comprehensively analyse the existence in Australia of patents on all research inputs. Given the increase in patent filings in the biotechnology category by international participants, it is fair to assume that some of these patents will block research undertaken in Australia if access cannot be successfully negotiated. Therefore any conclusions we make about the existence of patents over foundational discoveries, or research tool patents in general, must be somewhat tentative.

\footnotetext{
${ }^{118}$ The patenting of recombinant DNA technology closely followed the passage of the Bayh-Dole Act in the United States. This legislation aimed to promote the dissemination and exploitation of university inventions, by in effect mandating the patenting of university research, and encouraging exclusive licensing of those inventions. The basis of this was that exclusive licensing to small companies would best serve innovation. To this end, exploitation of the patent over recombinant DNA technology was wider than envisaged by the framers of Bayh-Dole; see NRC, above $\mathrm{n} 41$ at $41-42$.
} 


\section{CONTEXT CHAPTER 4: IMPACT OF PATENTS ON MEDICAL BIOTECHNOLOGY RESEARCH AND DEVELOPMENT}

\section{PATENTS AND PUBLIC SECTOR RESEARCH}

Commercialisation of biotechnology research is part of a wider trend favouring science that has commercial applicability in Australia. The interplay between public science and private commercialisation is a matter of ongoing debate in many areas of biological research and the influence of commercialisation on scientific research cannot be ignored. It would generally be accepted by most of the people involved in academic research, whether they are funders, policymakers or researchers, that the emphasis of that research has changed vastly over the last couple of decades. The ivory tower academy has had to learn the language of business economics. As part of this, research that has commercial implications will be favoured by funding agencies over pure science. Collaborative research ventures with industry will be highly regarded. This trend of encouraging commercialisation, particularly in the form of collaborations between the public and private sectors is also seen in other jurisdictions. ${ }^{119}$

One of the consequences of introducing commercial considerations into the academic sphere is that many of the scientists who are involved in upstream research and for whom academic kudos has in the past been sufficient reward are now required to consider the best ways to protect their intellectual property rights and transfer their technology to industry. This introduces sharper focus on commercial considerations in the research environment.

It is well recognised that there is a need to strengthen commercialisation of public sector research in Australia. For

119 For example, Tim Caulfield discusses these issues from the Canadian perspective in 'A Colloquy on the Romanow Report. Sustainability of the Health Care and Innovation Agendas: the Commercialisation of Genetic Research' (2003) 66 Saskatchewan Law Review 629. 
example, a Report of the Prime Minister's Science, Engineering and Innovation Council stated that:

To improve performance, we should ensure that research projects with commercial potential have every opportunity to move through the commercialisation process. This involves bringing together the exciting work already underway in our research laboratories, with what industry needs and what the market will embrace. ${ }^{120}$

In particular, the Report highlighted the need to increase the quantum of out-licensing and to create more spin off companies in order to improve the transfer of technology from the public to the private sector. $^{121}$

However, this elision between public and private research is not costfree. Arguably, it has accelerated challenges to traditional core science values summed up by Robert Merton as "universalism, collegiality, disinterestedness and organised scepticism”. ${ }^{122}$ One of the ways in which this new commercialised research culture could affect upstream research is in its impact on the dissemination of research results. The integrity of the individual researcher is promoted by the strong communal traditions of team-work and free exchange of ideas, results and research reagents. Integrity is further assured by subjecting research results to external testing and criticism through the peer review system and the publication of results in widecirculation refereed journals. This publication tradition has been the primary reward for academic scientists and the dominant measure of academic excellence. However, there may be valid commercial reasons, including the possibility of patenting, why the early disclosure of results is not always forthcoming. As Sherman has

\footnotetext{
${ }^{120}$ See, for example, Prime Minister's Science, Engineering and Innovation Council Commercialisation of Public Sector Research (2001) Report of Working Group presented at the Council's Seventh Meeting 28 June 2001 at 3, available at: http://www.dest.gov.au/science/pmseic (accessed 11 November 2003) (hereafter PMSEIC).

${ }^{121}$ Ibid at 3-4.

${ }^{122}$ R. Merton, The Sociology of Science (Chicago: University of Chicago Press, 1973). See also R. Eisenberg, 'Proprietary Rights and the Norms of Science in Biotechnology Research' (1987) 97 Yale Law Journal 177 at 182-184 (hereafter Eisenberg 1987); and A. Rai, 'Regulating Scientific Research: Intellectual Property Rights and the Norms of Science' (1999) 94 Northwestern University Law Review 77.
} 
pointed out, patents change both the forum and form in which research results are first disclosed. ${ }^{123}$ At the same time, it must be acknowledged that commercialisation per se need not ultimately cause a decrease in publication rate. On the contrary, evidence shows that researchers from government institutes in the United States that have formal partnerships with industry tend to have higher publication rates than those from non-industry aligned institutes. ${ }^{124}$

The novelty requirement is likely to have the most significant effect on the traditional norms of science because it requires that research data are kept secret until after the patent has been filed. However, once the patent has been filed, research results can be published provided that this does not compromise future intellectual property rights. In addition, the grace period which allows researchers to disclose their work before filing their patent applications without destroying the novelty of their inventions. Nevertheless, where patents are involved it is likely that there will be a longer time lag between research and publication than would otherwise be the case. The other option for protecting the economic value of research data is secrecy. Although the norms and rewards of science may have some congruency with the patent system, they would appear to have nothing in common with secrecy. ${ }^{125}$ One of the primary requirements of both publication and patenting is disclosure of information, allowing its subsequent use by others. The main difference is that use follows on immediately after publication, whereas for patenting, disclosure occurs at the start of the patenting period but use is not permitted until the end. Secrecy is premised on the fact that there is no disclosure requirement. Indeed, disclosure puts an end to the protection afforded by secrecy. For this reason the use of secrecy as a means of retaining control over information could create a “destructive, anti-intellectual climate". ${ }^{126}$

Attaching economic value to research results also may have other effects on scientific collegiality. Where, in the past, researchers often freely exchanged newly developed research reagents and other research tools, public sector institutes now often require recipients to

${ }^{123}$ B. Sherman, 'Governing Science: Patents and Public Sector Research' (1994) 7 Science in Context 515.

${ }^{124}$ United States Congress, Office of Technology Assessment, Federal Technology Transfer and the Human Genome Project (Washington, DC: US Government Printing Office, 1995).

${ }^{125}$ Eisenberg (1987), above n120.

${ }^{126}$ G. Poste, 'The Case for Genomic Patenting' (1995) 378 Nature 534. 
enter into contractual arrangements in the form of material transfer agreements. ${ }^{127}$ Even if no costs are involved, limitations are placed on the range of uses to which such materials can be put. This raises yet another concern about the so-called "post-academic" era of science: that objectivity could be lost as a result of commercial obligations. ${ }^{128}$ Objectivity is an aspect of the norm of disinterestedness, which requires impartiality in the reporting of research results. Commercial sponsors may have contractual rights to decide both the time and content of publications which may have a serious impact on this norm of science. We report on the views of our respondents in relation to a number of these issues in Part 2 of this Report.

\section{RESTRICTIONS ON ACCESS TO UPSTREAM PATENTS}

One of the two issues explored by Walsh, Arora and Cohen was whether the assertion of patent rights over foundational upstream discoveries is having the effect of undermining the advance of biomedical research. ${ }^{129}$ A notable feature of biomedical research is that complex research paths are required to fully exploit the potential of broad upstream inventions. ${ }^{130}$ A researcher or company may require access to a number of patents in order to commercialise an invention. Where access to one of those patents is restricted, there may be a detrimental effect on subsequent downstream research. Given that the essence of a patent right is the right to exclude others, there will invariably be some "routine under-use" in any well functioning patent system, and this may simply be a cost we pay for the operation of a patent system that otherwise benefits society. ${ }^{131}$

But where inventions over which access is restricted comprise foundational discoveries which themselves require further

${ }^{127}$ A. Rai and R. Eisenberg, 'Bayh-Dole Reform and the Progress of Biomedicine' (2003) 66 Law and Contemporary Problems 289.

${ }^{128}$ J. Ziman, 'Is Science Losing Its Objectivity’ (1996) 382 Nature 751.

${ }^{129}$ Walsh, Arora and Cohen, above n28 at 296-297.

130 A. Rai, 'Fostering Cumulative Innovation in the Biopharmaceutical Industry: The Role of Patents and Antitrust' (2001) 16 Berkeley Technology Law Journal 813 at 831. See also E.W. Kitch, 'The Nature and Function of the Patent System' (1977) 20 Journal of Law and Economics 265 (hereafter Kitch).

${ }^{131}$ M. Heller and R. Eisenberg, 'Can Patents Deter Innovation? The Anticommons in Biomedical Research’ (1998) 280 Science 698 at 699 (hereafter Heller and Eisenberg); R Eisenberg in NRC, above n41 at 9-10. 
development in order to produce consumer products, there is a real possibility that the patent system fails to fulfil its aim of promoting innovation. Patents are intended to promote innovation, and it may be questionable in some cases whether assertions of patent rights and exclusionary licensing practices achieve this aim. The move from public dissemination of research results, which in themselves constitute important research inputs, to more prolific patenting of research tools sets up the main precondition for the concern that research may be impeded. ${ }^{132}$

Two further preconditions may exacerbate the problem. First, broad interpretation of claims on upstream foundational discoveries may extend the reach of upstream patents and deter downstream innovators from researching in what they perceive to be a broad area of research. Second, reach-through rights to future inventions (for example, a right to a compound that acts on a patented target even though the compound itself is not described in the patent claims) could deter subsequent innovation. This will of course depend on how broadly the original patent claim is interpreted, and even if patent offices continue to interpret claims narrowly, courts are not precluded from construing them more broadly. ${ }^{133}$ This uncertainty may act to inhibit research in an area where researchers are concerned about how a patent claim may be interpreted.

When might an upstream invention be classified as "foundational" so that relatively uninhibited access is desirable? Of the many examples of patented inventions that are likely to constitute important foundational discoveries, many of the more prominent examples are those patented inventions discussed above, including recombinant DNA, PCR and Taq polymerase, embryonic stem cells, and genes and proteins that may potentially be important in terms of therapeutic applications. ${ }^{134}$ Walsh, Arora and Cohen suggest that there are two considerations when looking at this question: ${ }^{135}$

\footnotetext{
${ }^{132}$ Walsh, Arora and Cohen, above n28 at 296. The authors rely on their interview data to establish that there has been a surge in upstream patenting, and have no empirical data on whether there has been an increase in the proportion of upstream inventions patented. Anecdotal data from company and academic scientists suggested there has been a increase in defensive patenting and in university patenting.

${ }^{133}$ See Walsh, Arora and Cohen, ibid at 296-297.

${ }^{134}$ See the discussion above in Context Chapter 3.

${ }^{135}$ Walsh, Arora and Cohen, above n28 at 332-334.
} 
- how key is the invention or research tool to subsequent innovation and how broad a range of subsequent inventions might depend on the initial invention; and

- can the invention or research tool be used as a tool in the development of a number of inventions that will eventually compete with one another. ${ }^{136}$ If one researcher uses such a tool, there will be less incentive for a competing researcher to use it because their profits will be eroded. On the other hand, some research tools can be used by a number of innovators with no erosion of their profits. ${ }^{137}$

If an upstream invention is fundamental to competing downstream research applications, Walsh, Arora and Cohen contend that access to it is more likely to be restricted in some way, often through exclusivity in licensing. Exclusive exploitation of an invention will entail some social cost because the party exploiting the invention will not have the means to pursue every application. ${ }^{138}$ While this is certainly true, Walsh, Arora and Cohen point out that there may also be some social cost where patented technologies are widely licensed to many users. In this case, it may be less likely that access will be restricted completely, but arguably more likely that terms such as reach-through rights to future inventions will be imposed. It is nonetheless important in any case to consider the biological system being dealt with to determine whether there may be multiple ways of approaching a particular research issue. This will be one factor to consider in examining the impact of restricted access. In addition, how broadly patent rights are interpreted will determine the extent of research activities affected by those rights. ${ }^{139}$

Promoting access to mitigate the social cost associated with restricted access to an invention must however be balanced against the risk that the incentive to develop the invention in the first place will be lessened. ${ }^{140}$ This balance needs to be borne in mind whenever a consideration of these issues is undertaken.

\footnotetext{
${ }^{136}$ If so, the invention will be what is referred to as 'rival-in-use'. The example given by Walsh, Arora and Cohen is that of two compounds that block a receptor that is specific to a therapeutic approach to a disease. The discovery of one would decrease the profit of the other from use of its compound; above n28 at 332.

${ }^{137}$ Examples include PCR, microarrays and combinatorial libraries; Walsh, Arora and Cohen above n28 at 332.

${ }^{138}$ Walsh, Arora and Cohen, ibid at 333-334.

${ }^{139}$ Walsh, Arora and Cohen, ibid at 334-335.

${ }^{140}$ Walsh, Arora and Cohen, ibid at 333-334.
} 


\section{THE TRAGEDY OF THE ANTICOMMONS}

A complex patent landscape necessitates bargaining to allow the utilisation of patented products, methods and technologies at various stages of the research and development path. ${ }^{141}$ For some time, there has been concern that this proliferation of intellectual property rights over research inputs may present a daunting obstacle to successful bargaining in biomedical research.

Where no party has an effective privilege of use over all the rights necessary to conduct research to develop a resource, ${ }^{142}$ parties must reach agreements with the various owners of the rights to enable them to aggregate the rights they require access to. They may, however, have difficulty reaching agreement. ${ }^{143}$ This is because high transaction costs may stand in the way of agreement. ${ }^{144}$ If there were no impediments to successful bargaining, rights would be traded and resources effectively utilised. ${ }^{145}$ But where agreement with a number of rights holders is required, prohibitive transaction costs may lead parties to decide that exchanging rights is not worthwhile. ${ }^{146} \mathrm{~A}$ socially optimal level of consumption of the resource may not be

\footnotetext{
${ }^{141}$ The importance of bargaining for the transfer of rights is highlighted by much of the economic literature dealing with cumulative innovation and the optimal allocation of intellectual property rights, as recommendations on allocations are often predicated on the likelihood of successful bargaining taking place. See, for example, S. Scotchmer, 'Standing on the Shoulders of Giants: Cumulative Research and the Patent Law' (1991) 5 Journal of Economic Perepectives 29 (1991) (hereafter Scotchmer); H. Chang, 'Patent Scope, Antitrust Policy, and Cumulative Innovation' (1995) 26 Rand Journal of Economics 34; J.R. Green and S. Scotchmer, 'On the Division of Profit in Sequential Innovation' (1995) 26 Rand Journal of Economics 20; R. Merges and R. Nelson, 'On the Complex Economics of Patent Scope' (1995) 90 Columbia Law Review 839 (hereafter Merges and Nelson).

${ }^{142}$ M.A. Heller, 'The Tragedy of the Anticommons: Property in the Transition from Marx to Markets' (1998) 111 Harvard Law Review 621 at 668-669 (hereafter Heller).

${ }_{143}$ Ibid at 676-677.

${ }^{144}$ See further below Results Chapter 4.

145 R.H. Coase, 'The Problem of Social Cost' (1960) 3 Journal of Law and Economics 1.

${ }^{146}$ See Heller and Eisenberg, above n131; Heller, above n142; Eisenberg (2001), above n21. The reasons for breakdown in negotiations within industries reliant on cumulative innovation will vary from industry to industry. For an empirical examination of this issue see Merges and Nelson, above n141 at 843-844.
} 
achieved, resulting in a "tragedy of the anticommons" or under-use of the resource. ${ }^{147}$

The idea of an anticommons in biomedical research was first advanced by Michael Heller and Rebecca Eisenberg. They assert that there are two ways in which a government may inadvertently create an anticommons problem: through the creation of numerous overlapping property rights over potential products or resources, or through the use of reach-through licence agreements leading to licence stacking. In their view, the explosion of patent grants within the industry, and the increasing prevalence of restrictive licensing practices mean that an anticommons is inevitable. ${ }^{148}$

Heller and Eisenberg consider it unlikely that the biomedical industry will overcome an anticommons without legal intervention. First, transaction costs of bargains within this industry are particularly high. Secondly, different sectors of the industry may find reaching agreement difficult. Finally, upstream researchers may overvalue their patented inventions making the development of downstream products less worthwhile. Thus, the preconditions for an anticommons in biomedicine exist, and it is unlikely that the market will right itself unassisted. ${ }^{149}$ Existing empirical evidence on the topic is divided. For example, Walsh, Arora and Cohen found little evidence of an anticommons in biomedical research, but the NIH Working Group's Report suggests that increasing difficulties negotiating agreements over research tools is clear evidence that the conditions for an anticommons persist.

\section{THE CONSUMER PERSPECTIVE - RESTRICTIONS ON ACCESS TO BIOTECHNOLOGY-RELATED PRODUCTS}

Where patents relate to new developments in health care, there may be countervailing public policy considerations that have to be

\footnotetext{
${ }^{147}$ Heller, above n142 at 677.

${ }^{148}$ Heller and Eisenberg, above n131 at 699-700.

${ }^{149}$ Heller and Eisenberg, above n131 at 700-701; See also Eisenberg (2001) above n21 at 231-248. In addition, Eisenberg contends that different agents within organisations have different agendas, for example, scientists and technology transfer personnel within universities are generally at odds in what they are aiming to achieve; Eisenberg (2001), above n21 at 239-242.
} 
weighed against the incentive to innovate, such as access, cost and quality issues.

\section{Pharmaceuticals}

Participants in the pharmaceutical industry argue that patents are essential because of the high costs of the research and the commercialisation phases and the time lag between invention and marketing that arises out of regulatory requirements for drug approval. This combination of factors makes patent protection more crucial for the pharmaceutical industry than for most other industries. $^{150}$ It is often argued that without patent protection pharmaceutical research will simply not get done. Investment in the biotechnology industry carries even greater risks in terms of the cost of research, the failure of many products during commercialisation and the time lag between discovery and commercialisation. These costs are exacerbated by increased levels of upstream patenting of essential research tools, requiring payment of multiple licence fees, as discussed above.

All these factors encourage holders of biotechnological and pharmaceutical patents to charge high prices, well above the actual cost of production. At the same time, from the health care perspective it is desirable for innovative treatments to be rapidly made available to a wide sector of the community. In 2000 a partnership of relevant stakeholders formulated Australia's National Medicines Policy. ${ }^{151}$ The Policy has four central objectives:

- timely access to the medicines that Australians need, at a cost the community can afford;

- medicines meeting appropriate standards of quality, safety and efficacy;

- $\quad$ quality use of medicines; and

- maintaining a responsible and viable medicines industry. ${ }^{152}$

150 See P. Loughlan, 'Patents: Breaking the Loop' (1998) 20 Sydney Law Review 553 at 570 .

151 Available at: http://www.health.gov.au/pbs/natmedpol.htm (accessed 29 November 2001). The partnership includes Commonwealth, State and Territory Governments, health educators, health practitioners, other healthcare providers and suppliers, the medicines industry, healthcare consumers and the media.

${ }^{152}$ Ibid. 
The Policy states that cost should not constitute a substantial barrier to access to the medicines that people need, and that "normal market mechanisms may be tempered in access arrangements, to increase the affordability of important medicines." There would seem to be some conflict between this policy and the Government's patent policy. The fact that the Patents Act provides for possible extension of five years to the patent term for pharmaceutical patents is testimony to the high value placed on pharmaceutical research and development by the Federal Government. ${ }^{153}$ The trade off is that drug prices remain artificially high for a longer period than in other industries, which will clearly have a negative effect on consumer access.

The conflict between access and cost recovery is resolved to a certain extent in Australia by the national Pharmaceutical Benefits Scheme (PBS) ${ }^{154}$ Drugs are listed on the PBS by the Pharmaceutical Benefits Advisory Committee (PBAC). Once listed, drugs are available through prescription. Although the PBS does provide access to many drugs at these reasonable costs, the gap between prescription charges and actual costs for PBS items still has to be borne by the Australian community. This cost is substantial: in the year to 30 June 2001 a total of around AU\$4.9 billion was spent on PBS medicines, over AU $\$ 4.5$ billion of which was supplied by the Federal Government, a 19 percent increase from the previous year. ${ }^{155}$ Clearly, this rate of increase is not sustainable.

There is a mechanism in place to ensure that prescribers and consumers do not overly favour brand label drugs. The Minimum Pricing Policy requires that consumers pay any additional cost if they buy a particular brand of prescribed drug that costs more than the listed basic price. This mechanism is important from the government's perspective because it reduces the gap between the prescription charge and the actual cost of the drug. However, it only works when the drug is off patent and when cheaper generics are available. The gap between prescription charges and actual costs may be quite large when the drug is still on patent. In consequence, the

\footnotetext{
${ }^{153}$ Sections 70-87 Patents Act 1990 (Cth).

${ }^{154}$ Australian Institute of Health and Welfare, Australia's Health 1996 (Canberra: AGPS, 1996) at 180. The history of Australia's medicinal drug policy is described by K. Harvey and M. Murray, 'Medicinal Drug Policy' in H. Gardner (ed.), The Politics of Health $2^{\text {nd }}$ ed., (Melbourne: Churchill Livingstone, 1995) chapter 9.

${ }^{155}$ Pharmaceutical Benefits Scheme, Consumer Information available at: http://www.health.gov.au/pbs/consumer.htm (accessed 29 November 2001). See also Australia's Health, above n154 at 181.
} 
number of such drugs that can be included on the PBS is limited. Indeed, the National Medicines Policy cautions at page 2 that:

In the context of the ongoing development and release of new medicines which are often relatively expensive, it can be difficult to meet the community's expectations regarding subsidised access to all available treatments.

The issue of which new drugs do or do not make it onto the PBS becomes very much a political decision. ${ }^{156}$ It is likely that many of the new products arising out of biotechnology research and development will be considered by the PBAC to be too expensive for inclusion on the PBS, in which case the cost must be borne by the individual consumer. The impending Free Trade Agreement between Australia and the US further threatens the ongoing viability of the PBS. Without PBS listing, it is only when patents expire and when competing generic products become available that the Australian community as a whole will get the full benefit of new pharmaceutical developments. Having said this, most Australians do, nevertheless, currently have access to a wide range of pharmaceutical products at reasonable cost.

Thus, although the high cost of patented pharmaceuticals is a matter of ongoing concern, the balance between incentive to innovate and equitable access is not obviously out of kilter in Australia. ${ }^{157}$

\section{Devices and diagnostic tests}

Different considerations apply in relation to devices and diagnostic tests because the regulatory requirements are far less onerous than for drugs. Hence, the risks, time and expenses involved in the drug approvals process are not factors that need to be considered when considering the balance between device and diagnostic patent ownership and access rights. This is a particular issue for diagnostic

${ }^{156}$ See A.H. Harris, 'Economic Appraisal in the Regulation of Pharmaceuticals in Australia: Its Rationale and Potential Impact' (1994) The Australian Economic Review 99 at 103.

${ }^{157}$ The same cannot be said in developing and least developed countries, where the cost of patented pharmaceuticals is prohibitive. However, there are ongoing international efforts that are attempting to alleviate some of these access issues. See J. Nielsen and D. Nicol, 'Pharmaceuticals and Patents: the Conundrum of Access and Incentive' (2002) 13 Australian Intellectual Property Journal 21; and D. Nicol, 'Balancing Access to Pharmaceuticals with Patent Rights' (2003) 22 Monash Bioethics Review 50. 
tests. Once the gene sequence for a particular disease related gene has been identified and isolated, the development of a diagnostic test is not particularly onerous. At present only a small number of diagnostic genetic tests are covered by the Federal Government through its Medicare Benefits Scheme (MBS). These are: haemochromatosis, factor V Leiden, protein $\mathrm{C}$ or $\mathrm{S}$ deficiencies, antithrombin 3 deficiency and fragile $\mathrm{X}$ syndrome. ${ }^{158}$

It would seem that in the past, patent holders claiming rights over diagnostic tests have not been aggressively enforcing their rights against providers of testing facilities. However, there is a growing body of evidence to suggest that this situation is changing, particularly in the United States. This change in strategy has the capacity to significantly affect the provision of diagnostic testing services. Detrimental effects are most likely to occur when the patent or licence holder either refuses to license or imposes onerous terms in the licence agreement. Such terms may relate to the price of tests, the quantity of tests that can be performed, which laboratories the tests can be performed in, whether further research is allowed to improve the quality and specificity of the tests, and so on.

Recent research in the United States by Mildred Cho and her colleagues shows that a number of patent and licence holders are actively enforcing their patents against providers of genetic tests by requiring licences or refusing to license. ${ }^{159}$ This has reportedly led to a number of test providers ceasing to perform a genetic test they had previously offered and to a number of others deciding not to develop or perform a test because of the patent considerations.

Searches of patent databases for equivalent Australian patents show that three of these United States patents have direct equivalents in Australia and four others are the subject of Australian patent applications (Table 1). Closely related Australian patents or patent applications (that is, having the same patent holder and subject matter) exist for most of the others. Only three have no direct or closely-related equivalents in Australia.

\footnotetext{
${ }^{158}$ From the Medicare Benefits schedule, as reported in ALRC, above n18 at 93.

${ }^{159}$ M.K. Cho, S. Illangasekare M.A. Weaver D.G.B. Leonard and J.F. Merz, 'Effect of Patents and Licenses on the Provision of Clinical Genetic Testing Services' (2003) 5 Journal of Molecular Diagnostics 3 (hereafter Cho and others 2003); Merz and others, above n43.
} 
Table 1: Patents linked to cessation of tests in the United States and equivalent Australian patents.

\begin{tabular}{|c|c|c|c|c|}
\hline Test $^{160}$ & US patent $^{161}$ & Patent holder & $\begin{array}{l}\text { Equivalent } \mathrm{AU} \\
\text { patent }^{162}\end{array}$ & $\begin{array}{ll}\begin{array}{l}\text { Related } \\
\text { patent }\end{array} & \text { AU } \\
\end{array}$ \\
\hline $\begin{array}{l}\text { Apolipo- } \\
\text { protein E }\end{array}$ & $\begin{array}{l}\text { US5508167 } \\
\text { US6027896 } \\
\text { and } \\
\text { US5716828 }\end{array}$ & Duke University & & $\begin{array}{l}\text { AU677614 and } \\
\text { AU200173661 }\end{array}$ \\
\hline \multirow[t]{2}{*}{$\begin{array}{l}\text { Hereditary } \\
\text { breast/ovarian } \\
\text { cancer }\end{array}$} & $\begin{array}{l}\text { US5753441 } \\
\text { (BRCA1) }\end{array}$ & $\begin{array}{l}\text { Myriad Genetics, } \\
\text { Inc }\end{array}$ & & $\begin{array}{l}\text { AU691958, } \\
\text { AU686004 and } \\
\text { AU691331 }\end{array}$ \\
\hline & $\begin{array}{l}\text { US6051379 } \\
\text { (BRCA 2) }\end{array}$ & Oncormed, Inc ${ }^{163}$ & AU199893216 & \\
\hline $\begin{array}{l}\text { Duchenne/ } \\
\text { Becker } \\
\text { muscular } \\
\text { dystrophy }\end{array}$ & US5541074 & $\begin{array}{l}\text { The Children's } \\
\text { Medical Center } \\
\text { Corp }\end{array}$ & & $\begin{array}{l}\text { AU633249 and } \\
\text { AU200073786 }\end{array}$ \\
\hline $\begin{array}{l}\text { Hereditary } \\
\text { hemo- } \\
\text { chromatosis }\end{array}$ & $\begin{array}{l}\text { US5705343 } \\
\text { US5712098 } \\
\text { and } \\
\text { US5753438 }\end{array}$ & $\begin{array}{l}\text { Mercator } \\
\text { Genetics, Inc }\end{array}$ & AU733459 & \\
\hline $\begin{array}{l}\text { Myotonic } \\
\text { dystrophy }\end{array}$ & $\begin{array}{l}\text { US5955265 } \\
\text { and } \\
\text { US5977333 }\end{array}$ & $\begin{array}{l}\text { MIT and } \\
\text { University of } \\
\text { Wales College of } \\
\text { Medicine }\end{array}$ & & AU199335059 \\
\hline $\begin{array}{l}\text { Canavan } \\
\text { disease }\end{array}$ & US5679635 & $\begin{array}{l}\text { Maimi Children's } \\
\text { Hospital Research } \\
\text { Institute }\end{array}$ & AU199473207 & \\
\hline
\end{tabular}

${ }^{160}$ The listed tests are those referred to as being stopped in some genetic testing laboratories in the United States study by Mildred Cho and her colleagues, ibid, Table 2.

${ }^{161}$ The United States patents that included claims covering the performance of those tests and holders of those patent were also reported in Cho and others 2003, ibid.

162 Equivalent Australian patents were traced using the AU Published Patent Searching database at http://apa.hpa.com.au:8080/ipapa/qsearch and the European Commission’s esp@cenet database at http://ec.espacenet.com/espacenet/ between 20 March and 9 April 2003. The six digit numbers signify granted patents, nine digit numbers are applications, the first four digits signifying the year of application.

${ }_{163}$ Note that the original British patent for BRCA2 was owned by a consortium of the Cancer Research Campaign Technology and Duke University, and was exclusively licensed to OncorMed, subject to certain stringent limitations relating to counselling and other matters. Myriad has an exclusive licence to OncorMed's patents for the provision of genetic testing services. See M. Rimmer 'Myriad Genetics: Patent Law and Genetic Testing' (2003) 25 European Intellectual Property Review 20 at 22-23. 


\begin{tabular}{|c|c|c|c|c|}
\hline \multirow{4}{*}{$\begin{array}{l}\text { Spino- } \\
\text { cerebellar } \\
\text { ataxia (SCA1 } \\
\text { SCA2, SCA3, } \\
\text { SCA6) }\end{array}$} & $\begin{array}{l}\text { US5834183 } \\
\text { and } \\
\text { US5741645 } \\
\text { (SCA1) }\end{array}$ & $\begin{array}{l}\text { Regents of } \\
\text { University of } \\
\text { Minnesota }\end{array}$ & No equivalent & \\
\hline & $\begin{array}{l}\text { US6251589 } \\
\text { (SCA2) }\end{array}$ & SRL, Inc & AU199664698 & \\
\hline & $\begin{array}{l}\text { US5840491 } \\
\text { (SCA3) }\end{array}$ & Kakizuka, A & No equivalent & \\
\hline & $\begin{array}{l}\text { US5853995 } \\
\text { (SCA6) }\end{array}$ & $\begin{array}{l}\text { Research } \\
\text { Development } \\
\text { Foundation }\end{array}$ & AU735756 & \\
\hline $\begin{array}{l}\text { Adenomatous } \\
\text { polyposis of } \\
\text { the colon }\end{array}$ & US5352775 & $\begin{array}{l}\text { Johns Hopkins } \\
\text { University }\end{array}$ & & AU199213669 \\
\hline \multirow[t]{2}{*}{$\begin{array}{l}\text { Charcot-Marie } \\
\text { Tooth type 1A }\end{array}$} & US5780223 & $\begin{array}{l}\text { Baylor College of } \\
\text { Medicine }\end{array}$ & & AU199222265 \\
\hline & US5691144 & $\begin{array}{l}\text { Athena } \\
\text { Diagnostics, Inc }\end{array}$ & No equivalent & \\
\hline $\begin{array}{l}\text { Fragile X } \\
\text { syndrome }\end{array}$ & US6107025 & $\begin{array}{l}\text { Baylor College of } \\
\text { Medicine }\end{array}$ & AU199221854 & \\
\hline $\begin{array}{l}\text { Huntington's } \\
\text { disease }\end{array}$ & US4666828 & $\begin{array}{l}\text { The General } \\
\text { Hospital Corp }\end{array}$ & & $\begin{array}{l}\text { AU676001 and } \\
\text { AU673575 }\end{array}$ \\
\hline $\begin{array}{l}\text { Factor V } \\
\text { Leiden }\end{array}$ & US5874256 & Rijks Universiteit & AU690644 & \\
\hline
\end{tabular}

These results clearly indicate that the capacity exists for a number of gene patents to be enforced against providers of diagnostic services in Australia. The implication from these results is that people in the United States may well be denied access to new genetic tests because of enforcement actions by patent holders. Hence, in this situation the balance between innovation and access may be skewed too far in favour of innovation. ${ }^{164}$ We discuss our data on this issue in Results Chapter 6.

164 Assuming that patents covering genetic tests do indeed encourage innovation, which in itself is open to question. 


\section{CONTEXT CHAPTER 5: STUDY METHODS}

This study was conducted in two parts:

- a quantitative component using survey data; and

- a qualitative component using a semi-structured interview format.

The aim of the study was to gather data through the surveys which would identify issues for further analysis within the interviews. We were aware when preparing the surveys that response rates to surveys in this industry are usually relatively low. For example, Hopper and Thorburn reported a 13 percent response rate to their 2002 survey, and attributed this to "survey fatigue". ${ }^{165}$ Despite the likelihood that we too would have a modest response rate, we nevertheless felt that the surveys were an important component of the study and represented the most appropriate method of generating preliminary data for further investigation.

\section{SURVEYS}

The initial component of the study consisted of written surveys mailed to respondents falling within three sectors of the biomedical industry: private sector biotechnology and pharmaceutical companies, research institutions and diagnostic testing facilities. The surveys were conducted with a view to addressing the issues raised in Part 1 of this Report, and to identifying issues on which to focus in the interview portion of the study.

\section{Private and public companies}

A component of this study was to construct a database containing details of Australian biotechnology and pharmaceutical companies, (including international companies with an Australian office) and to document, in particular, the patent portfolios and alliance activity of these companies. This database was completed using data obtained

\footnotetext{
${ }^{165}$ Hopper and Thorburn, above n22.
} 
from the Australian Securities and Investments Commission, and publicly available information including material from company websites and industry reports. ${ }^{166}$ Information from the database was used to identify respondents for survey mail-out. Companies were identified as being relevant to the survey if their activities comprised core biotechnology activities, or if their activities were in some way biotechnology related. ${ }^{167}$

Although this research project was concerned with the biomedical biotechnology industry, this component of the project was not limited to the biomedical sector of the industry. Respondents were asked to describe their area of activity or research, and so we were able to identify companies involved in biomedical research and those involved in other activities. Our intention was to obtain some interesting comparative data. However, the overwhelming majority of responses were from the biomedical sector of the industry. Only four of the responses received were from companies that could not be classified as primarily biomedical. Of the four, three reported no patent activity and two of these reported no collaborative or licensing activity. Although data from all of these respondents is included in the overall results, we make specific reference to the two nonbiomedical companies that reported patent, licensing or collaborative activity in Results Chapters 2, 4 and 5. ${ }^{168}$

Approximately 180 surveys were mailed to companies in June 2002. ${ }^{169}$ The same survey was sent to both biotechnology and pharmaceutical companies. Follow-up letters were sent to respondents four weeks after the surveys were mailed out, and follow-up telephone calls were subsequently made. The survey asked 52 questions about the structure and activities of the company, the company's involvement in patenting, collaborations and licensing, and the views of the respondent on patenting within the industry.

\footnotetext{
${ }^{166}$ We thank Rebecca Keep and Tim Graham for their assistance in compiling the database, and Brendan Gogarty for creating the database.

${ }^{167}$ Core biotechnology companies are companies whose business is entirely or substantially biotechnology related: See Ernst \& Young 1999, above n1.

${ }^{168}$ One of these respondents appeared to be involved in biomedical applications to some degree.

${ }^{169}$ Ernst \& Young listed the number of core biotechnology companies in Australia as 20 listed companies and 100 private unlisted companies in its 1999 Report, above n1. In a later survey, the number was estimated to have increased to 190; Ernst \& Young 2001, above n1. A number of the companies targeted by our survey had only peripheral biotechnology-related activities..
} 
Of the surveys sent out, 49 completed surveys were returned, yielding a response rate of 27 percent. In addition, six respondents contacted us and informed us that they did not wish to participate in the survey either because they did not consider it to be relevant to their company's activities, or they considered the information sought to be commercially sensitive. A number of respondents who subsequently participated in face-to-face interviews notified us that they had not completed the survey because they believed that they could participate more effectively in providing qualitative rather than quantitative data to us. Consequently, they were willing to take part in interviews. Although we concede that the response rate is low in relative terms, it compares favourably with other voluntary mailout surveys conducted within the industry. ${ }^{170}$ Further, if we had targeted specifically biomedical companies in distributing the company survey, we would expect our response rate to be more favourable than it was. ${ }^{171}$ It would be fair to assume that the 45 biomedical and pharmaceutical companies from which we received responses represents a significant proportion (perhaps in excess of 40 percent) of Australian companies engaged in biomedical and related applications.

\section{Research institutions}

Printed surveys were mailed out to 39 research institutions on 17 March 2003 and reminder letters were sent in June 2003. As previously noted, we use the term 'research institution' to include universities, government institutions, publicly-funded independent research institutions and private research institutions. These institutions were identified by our prior knowledge of the research sector and using standard search engines. ${ }^{172}$ The survey asked 42 questions about research activities, the institution's involvement in patenting, collaborations and licensing, awareness of patents held by others and views on patenting. Twenty-three surveys were returned, yielding a response rate of 59 percent.

\footnotetext{
${ }^{170}$ See, for example, Hopper and Thorburn, above n22.

171 Ernst \& Young estimated that approximately 47 percent of Australian biotechnology companies are operating in the area of human health, including diagnostics and therapeutics. They further estimated that approximately 13 percent of companies are operating in the areas of Genomics, Proteomics and Bioinformatics; Ernst \& Young 2001 above n1 at 13.

172 We thank Tim Graham for research assistance in identifying relevant institutions.
} 


\section{Genetic testing laboratories}

Printed surveys were mailed out to the laboratories offering diagnosis of genetic disorders listed on the Human Genetic Society of Australia's website in November 2002 and reminder letters were sent in December 2002. The surveys asked 61 questions about the laboratory, its clinical activity, research and patent activity and collaborations. A total of 52 surveys were dispatched. Eighteen were returned (35 percent response rate). These detailed surveys were supplemented by short telephone surveys conducted in March and April 2003 asking six questions about the laboratory, the tests it performs, payment of licence fees and/or royalties, receipt of notifications from patent or licence holders, responses to notifications, and views on patents. The six questions were only asked if respondents indicated that they had not returned the written survey. Hence we are reasonably confident that the telephone survey respondents did not overlap with the written survey respondents. There were thirteen responses to the telephone survey, yielding a total response rate of 60 percent.

\section{INTERVIEWS}

Forty interviews were conducted with various respondents falling within the categories of private companies, research institutions and diagnostic testing facilities between August 2002 and July 2003. Participants were selected based on prior contacts, media reports, internet based search engines and databases, and snowball sampling.

Within the category of private sector companies, we interviewed chief operating executives, intellectual property personnel and bench

scientists. Within the category of research institutions we interviewed directors of research groups, bench scientists and technology transfer personnel. Within the category of diagnostic testing facilities, we interviewed directors of research groups. We also interviewed a number of other respondents with expertise in the area, including patent attorneys, licensing consultants and government and trade representatives. Interviews were conducted on an anonymous basis. We proceeded on this basis because of the confidential nature of the data being gathered; anonymity in studies in the industry is standard practice. We also became aware from speaking with industry contacts prior to the commencement of the study that a majority of respondents were unlikely to respond to surveys or participate in 
interviews unless anonymity could be guaranteed. During a considerable number of interviews, respondents sought assurances to this effect.

Details of respondents by organisation type and occupation are contained in Table 2. Respondents were selected to provide a representative sample of various sectors within the biomedical industry, from research institutions and companies operating at the upstream end of the industry, through to companies involved in downstream drug development and therapeutic applications.

Table 2: Interview respondents

\begin{tabular}{|l|c|c|c|c|}
\hline Respondent type & $\begin{array}{c}\text { Business/ } \\
\text { IP/ legal } \\
\text { manager }\end{array}$ & $\begin{array}{c}\text { Lab } \\
\text { director/ } \\
\text { scientist }\end{array}$ & $\begin{array}{c}\text { Managing } \\
\text { director/ } \\
\text { CEO }\end{array}$ & $\begin{array}{c}\text { Total } \\
\text { interviews }\end{array}$ \\
\hline $\begin{array}{l}\text { University Tech } \\
\text { Transfer Office }\end{array}$ & 3 & 3 & & 3 \\
\hline $\begin{array}{l}\text { Diagnostic } \\
\text { Testing Facilities }\end{array}$ & 1 & 4 & 3 & 8 \\
\hline $\begin{array}{l}\text { Research } \\
\text { Institutions }\end{array}$ & 2 & 1 & 1 & 3 \\
\hline $\begin{array}{l}\text { Tech Transfer } \\
\text { Companies }\end{array}$ & 4 & 1 & 1 & 4 \\
\hline $\begin{array}{l}\text { Upstream } \\
\text { Companies* }\end{array}$ & 3 & & 3 & 3 \\
\hline $\begin{array}{l}\text { Intermediate } \\
\text { Companies* }\end{array}$ & & & & 4 \\
\hline $\begin{array}{l}\text { Downstream } \\
\text { Companies* }\end{array}$ & & & & 2 \\
\hline $\begin{array}{l}\text { Pharmaceutical } \\
\text { Companies }\end{array}$ & & & & 2 \\
\hline $\begin{array}{l}\text { Device } \\
\text { Companies }\end{array}$ & & & & 1 \\
\hline $\begin{array}{l}\text { Licensing } \\
\text { Consultants }\end{array}$ & & & & 2 \\
\hline Patent Attorneys & & & & 2 \\
\hline $\begin{array}{l}\text { Trade Association } \\
\text { Representatives }\end{array}$ & & & & 4 \\
\hline $\begin{array}{l}\text { Government } \\
\text { representatives }\end{array}$ & & & & \\
\hline
\end{tabular}

The categories marked with an * in Table 2 are fairly fluid in that some respondents conducted activities that could fit into more than one category. We have placed these respondents in the category that best fits their primary activities. It was also difficult to classify the 
interviewees within respondent organisations, so we have described them as accurately as possible. In several cases, interviews were conducted with more than one person from within an organisation. Although we have included this as one interview within our tally of interviews, we have provided descriptions of all the personnel interviewed.

Within respondent organisations, business, intellectual property and legal managers were the group most interviewed. We conducted 19 interviews of personnel who fell into this category compared with nine laboratory directors and scientists and nine managing directors. We recognise that responses may vary depending on the particular person within an organisation who is interviewed. In some cases, where a business, intellectual property or legal manager was interviewed, we may have received a different response from, for example, a lab scientist. There are a number of reasons why we chose to interview managers rather than scientists. In particular, we selected business, intellectual property and legal managers because of their knowledge of the issues being investigated by us. In some cases another member of an organisation referred us on to them. Many institutions being considered were relatively small and there was evidence of close contact and discussion of relevant issues between managers and scientists within respondent organisations. In many cases, business, intellectual property and legal managers came from a science background, often from within the organisation itself. They therefore had a good understanding of the issues associated with the conduct of research and intellectual property in the relevant field, as well as complex technology transfer issues. Difficulty in persuading scientists to participate in interviews is also a common theme in some other studies. ${ }^{173}$

Similarly, many managing directors and CEOs come from a science background and are well versed in the intellectual property activities of their respective companies. We do not therefore perceive the relatively low numbers of scientists interviewed as a significant omission, although we do concede that it may mean that responses differed to a degree. We do, however, hold the view that the level of knowledge of technology transfer issues of respondents falling into the categories of business, intellectual property and legal managers, and managing directors and CEOs, made them particularly valuable classes of interview respondents.

\footnotetext{
${ }^{173}$ See, for example, NIH, above n37 at 6.
} 
The resulting sample gave us some reliable insights into views and issues within the industry. We do not claim that this was a truly random sample. Respondents were selected to enable us broad coverage of a range of players within the industry, but at times were selected fairly opportunistically. However, given the number of respondents interviewed and the areas of the industry covered, the sample paints a broadly representative picture of issues facing the industry and trends within the industry.

Most of the respondents interviewed were involved in human genetic or biomedical research and/or commercialisation. However, several respondents falling outside these categories, or falling into more general or peripheral categories were interviewed in order to obtain some comparative data. One respondent was involved in a biotechnology CRC unrelated to human health applications. Two company respondents were involved in medical device research and development, and one respondent from the bioinformatics sector took part in the study. One of the research institution respondents was involved in plant studies. Some respondents were involved in applications related to human health, in addition to other broader applications. We indicate throughout the course of this Report where data from interviews with these respondents is referred to.

The respondents were asked a series of questions that conformed to a flexible format and were designed to elicit responses that gave some insight into the extent of the issues already raised in Part 1 of this report. Specifically, we were interested in finding out about how people exploited their own intellectual property and how they dealt with relevant intellectual property owned by others. From the selfexploitation perspective, we wanted to know the extent to which Australian participants in the biotechnology industry are encountering significant barriers in transfer of technology. From the perspective of accessing intellectual property owned by others, we wanted to know the extent to which particular patents have a restrictive effect on downstream access, and whether an anticommons effect could be said to be occurring in the industry. Respondents were asked generally about the patent and licensing activity of their company or institution, and were then asked a series of questions designed to examine issues particularly relevant to them in more detail. The interviews were structured to allow us to consider whether patents and patent licensing are having an effect on research and/or the commercialisation of 
Study Methodology

patents, and ways in which respondents are overcoming any such effects. 
Context Chapter 5 


\section{PART 2: RESULTS OF THE EMPIRICAL STUDY}




\section{RESULTS CHAPTER 1: RESEARCH AND PATENT ISSUES}

The strengths in the biomedical research in Australia were generally recognised by the respondents to our surveys and by interview respondents. As one respondent put it:

Australia is food for the creative side of innovation, thinking outside the square. Because of our isolation we have the courage as well as intelligence.

Research institution and company respondents alike confirmed that there are extensive research opportunities in Australia. Public sector researchers have access to funding for research projects from public funders such as the NHMRC and the ARC and also from overseas sources, particularly the United States National Institutes of Health.

They also have access to research funding from the private sector through collaborations with industry partners both within Australia and overseas. Our results show that one of the dominant features of the biotechnology industry in Australia is widespread alliance activity between the public and private sectors. Details of these arrangements are reported in Chapter 3 of our results.

Finally, research organisations also have the capacity to feed back licence fees and royalties obtained through licensing out existing innovations into future research projects. However, one research institution respondent commented that it is now much harder to get money from industry for basic research than it was in the past. He stated that:

In the past, industry may have funded public good work along the way. Now industry is much more focused and in order to secure funding it is necessary to go into an area that is valuable to industry. Consequently, for gene discovery work, the balance is shifting back to public funding because industry cannot readily make money out of it. So, we are much more likely to go to the NHMRC or the NIH than industry. If we find something along the way, we then seek a commercial partner. 
This comment was certainly not isolated, and has implications for the patent system as an incentive for innovation; basic research is a crucial resource for the biotechnology industry and clearly the impact of a strong focus on patenting is being felt at a fundamental research level.

In this chapter we report on survey and interview data relating to patent activity in Australia and on the views of our respondents about the value of patents and the impact of patents on research and development.

\section{PATENT ACTIVITY}

There is widespread ownership of patents in the biotechnology industry and in research institutions involved in this area of research. Thirty-seven of the 49 respondents to the company survey said that their company owned patents (76 percent). Similarly, 19 of the 23 respondents to the research institutions survey said they owned patents (82 percent) and one of the others stated that their institution had an equity share in the company owing patents for inventions created in the institution. ${ }^{174}$

Conversely, only two of the 18 respondents to the diagnostics survey indicated that they owned patents. However, it must be taken into account that of the 18 respondents, only 13 said that they were involved in research. On this basis, 15 percent of those diagnostics facilities with a research program had patents. These results probably reflect the nature of research being conducted in diagnostics facilities, but they are also likely to reflect different attitudes about patenting and commercialisation.

One respondent involved in diagnostics research commented that although his laboratory had patentable technology it had not been patented because the patent process was simply too hard, in part because of lack of expertise but also in part because of intransigence on the part of some parties regarding ownership. He added that at the end of the day unless the patent process is made easy he would not

\footnotetext{
${ }^{174}$ It is perhaps surprising that a higher percentage of research institutions than companies reported that they owned patent. Some of the possible reasons for this are explored later when we consider technology transfer.
} 
bother. Another research institution respondent described the patenting process as boring and painful.

Only a very small number of company respondents commented that patenting was not part of their commercial strategy. One respondent said that his company's strategy was to rely on trade secrecy rather than patents. His justification was that patents are only as good as your defence of them. It will become apparent that defending patents is a major issue.

Many patent holders, particularly those in the public sector, do not have adequate funding to contemplate instituting infringement proceedings or opposition proceedings to challenge the validity of competitors' patents. Nevertheless, it is clear that in general patenting is seen as an essential part of the mainstream commercialisation process in Australia.

Trade secrecy may well be a valid alternative strategy in some areas of research and development, particularly when it is difficult to reverse engineer. However, one respondent pointed out that in the area of genetic technology you don't have to be too clever to reverse engineer and therefore patents are absolutely necessary. This was confirmed by another respondent who stated that: "often you put in a patent and a competitor will have theirs ready to go a week later. Trade secrecy doesn't make a lot of difference at this stage, but may be useful at the lead compound stage.”

\section{Numbers of patents}

As previously discussed, there has been a huge escalation in the number of biotechnology patent applications filed in most countries, including Australia. Indeed, some gene sequencing companies have issued statements reporting that they have filed thousands of applications. $^{175}$ We sought information about the quantum of patenting in each of the three sectors of the industry that we surveyed. Respondents were asked to specify the number of patents that they owned. The results are summarised in Table 3.

\footnotetext{
${ }^{175}$ See Nicol and Nielsen, above n4 at 360.
} 
Table 3: Numbers of patents held

\begin{tabular}{|c|c|c|c|}
\hline Number & $\begin{array}{c}\text { Research } \\
\text { institutions (\%) }\end{array}$ & Companies (\%) & $\begin{array}{c}\text { Diagnostic } \\
\text { facilities with } \\
\text { research base (\%) }\end{array}$ \\
\hline 0 & $3(13)$ & $12(25)$ & $11(85)$ \\
\hline 1 & $2(9)$ & $2(5)$ & $1(8)$ \\
\hline $2-4$ & $4(17)$ & $7^{\#}(14)$ & \\
\hline $5-9$ & $6^{\#}(26)$ & $4(8)$ & \\
\hline $10-19$ & $2(9)$ & $7^{\# * *}(14)$ & \\
\hline $20-50$ & $5(22)$ & $4(8)$ & $1(8)$ \\
\hline$>50$ & $0(0)$ & $9^{*}(18)$ & \\
\hline Not specified & $1(4)$ & $3(6)$ & \\
\hline No answer & $0(0)$ & $1(2)$ & \\
\hline
\end{tabular}

Three of the company respondents referred to in Table 3 distinguished between granted patents and applications (marked as * numbers represent granted patents only). Given the time lag between application and grant, it is likely that a number of the patents referred to by respondents in Table 3 have not yet been granted. Ultimately, some of these may fail to satisfy the patent requirements, and hence the number of granted patents may actually be lower than reported herein. Nevertheless, the results give broad guidance as to the quantum of patenting by Australian organisations surveyed by us. One respondent in the research institutions survey and two respondents in the company survey referred to the numbers of families of patents rather than the number of patents per se (marked as ${ }^{\#}$ ). As such, it is possible that a number of respondents may have been referring to patent families rather than individual patents.

These results show that large scale patenting is not the norm in the Australian industry, or at least in the sectors that responded to our surveys. For example, these results show that the majority of respondents in research institutions and in the private sector have less than 10 patents. These results probably reflect the structure of the industry in Australia. Although quality research may be performed in Australian research institutions, there are insufficient resources to support large scale patenting. The private sector is largely made up of small upstream and intermediate companies that are also likely to lack the resources to support large patent portfolios. Of those companies that reported owning more than 50 patents, only one reported that the number of patents owned by the company was in the "thousands". One other put the number at "hundreds". Both of these were foreign owned companies. Only one respondent from an Australian owned company reported owning more than 150 patents. The rest fell 
somewhere between 50 and 150. Most of these reported that their activities were primarily downstream, although one respondent said that their company owned 123 patents and engaged in both upstream and downstream research.

\section{Types of patents}

Survey respondents were also asked to identify the nature of their patents within the broad categories of: gene sequence, research tool, gene product, drug, diagnostic and other. The results are summarised in Table 4.

Table 4: Types of patents held

\begin{tabular}{|l|c|c|c|}
\hline Types & $\begin{array}{c}\text { Research } \\
\text { institutions (\%) }\end{array}$ & Companies (\%) & $\begin{array}{c}\text { Diagnostic } \\
\text { facilities with } \\
\text { research base (\%) }\end{array}$ \\
\hline Gene sequence & $6(26)$ & $14(29)$ & $1(8)$ \\
\hline Research tool & $9(39)$ & $8(16)$ & $1(8)$ \\
\hline Gene product & $5(22)$ & $8(16)$ & $2(15)$ \\
\hline Drug & $10(43)$ & $18(37)$ & \\
\hline Diagnostic & $11(48)$ & $15(31)$ & \\
\hline Other & $4(17)$ & $15(31)$ & \\
\hline
\end{tabular}

These figures show the number of respondents with patents that include claims in each of these areas rather than the actual number of patents. A single patent may fall within a number of the categories listed in the survey questions, hence the total percentages add up to more than 100 . These results are intended to provide broad guidance as to the areas in which patent applications are being made rather than precise quantitative data. In the category of "other" patent types, respondents listed such things as equipment, therapies, bioactive products and formulations and four of the company respondents listed devices.

These results show that the types of patents held by respondents spread across the whole gamut from gene sequences to drugs. Some of the patents owned by Australian companies are likely to be foundational in nature (the GTG junk DNA patents being the prime example). However, as previously indicated, the majority of the most controversial foundational patents that have been discussed in the literature are foreign-owned. 


\section{Filing of patents}

Most respondents stated that they or their clients routinely patented in the United States and in a number of European countries. The next most favoured country was Japan. Some respondents stated that they started with a broad sweep of countries and then narrowed depending on a number of financial and other decisions. For example, one respondent stated that they would consider patenting in countries where a disease was prevalent as well as the countries with the largest markets. However, the cost involved in maintaining a patent in a number of countries was a major factor in deciding both where to patent in the first instance and where to keep patents active.

Although most respondents said that they invariably took out patents in Australia, there was a certain degree of ambivalence about the value of Australian patents. Indeed, one respondent commented that his company filed in Australia only "out of nostalgia”. In general the reason given for the lack of enthusiasm about patenting in Australia was the small size of the Australian market for products sold under patent. Clearly this is a good reason for not patenting exclusively in Australia. However, it would be difficult for an Australian company to justify excluding Australia altogether from the list of companies in which to pursue patent applications. Indeed, although disparaging remarks about the value of Australian patents were common, in practice no single respondent actually said that they did not file patents in Australia.

For some respondents, patenting in Australia seems to be more important from the public perception perspective than from a financial one. In particular, respondents from public sector institutions and public companies commented on the desirability of being seen to be giving something back to the Australian public: unless products are patented here they will not be marketed here. Public company respondents said that they simply had to do this for public interest purposes. For public research institutions, respondents commented that there was even stronger justification to patent in Australia because of the mandate to ensure benefit for Australia economically and socially.

One respondent noted that, because of the small volume of patents passing through the Australian Patent Office and the relatively smooth process of examination, sometimes an Australian patent will 
be pursued as a test case and used as a basis for other applications elsewhere.

\section{VIEWS ON PATENTS}

\section{The Australian patent system}

One of the problems with the Australian patent system that was consistently identified by respondents was the breadth of patent claims that are granted here. Respondents noted that in contrast, the United States Patent and Trademarks Office is much more rigorous in its analysis of patent claims and will reject claims that go too far beyond the scope of the invention. However, another respondent expressed an entirely contrary view, that if anything the United States Patent and Trademarks Office grants broader patents than the Australian Patent Office. No other respondent backed up this assertion. Interestingly, a recent comparative study by Melanie Howlett and Andrew Christie of patent office practice in the United States, Europe, Japan and Australia relating to examination of EST patents provides no evidence to support these views. In fact, Howlett and Christie found that although the approach taken to examination differs slightly between offices, the results are essentially the same in that in all jurisdictions studied EST patents will often fail to fulfil the essential patenting requirements and hence will be rejected. ${ }^{176}$

Many of our respondents emphasised the importance of obtaining good patents. The need for this will become apparent in later discussions. In summary, the argument is that if patents are overly broad or otherwise have uncertain validity they may be ignored by other players in the field. The patent holder will then have to undertake the costly process of enforcing the patent through infringement proceedings, which carries the additional risk that if a counterclaim is made the patent may be declared invalid. However, as one patent attorney noted, a broad claim, even if invalid is very powerful in the right hands.

Respondents identified as one of the major problems the lack of resources for the Australian Patent Office to do its job adequately. Although this problem is alleviated to a certain extent by the right to

\footnotetext{
${ }^{176}$ M.J. Howlett and A.F. Christie An Analysis of the Approaches of the Trilateral and Australian Patent Offices to Patenting Partial DNA Sequences (ESTS) (2003) IPRIA Working Paper 09/03.
} 
pre-grant challenge in opposition proceedings, this significantly adds to the cost of participating in the patent and commercialisation process. As one respondent commented:

The Australian Patent Office is doing a good job for what it has. However, it is becoming more focused on a 3 hour examination. I have become disillusioned in that. It is being perceived as more of a rubber-stamping office. It should be letting through only good patents, but it lets through rubbish. Litigation is relied on to sort it out. This is against the purpose of the patent system.

Some respondents made specific comments relating to the 2001 amendments to the Patents Act 1990, which particularly affect novelty and inventive step. One respondent commented that these are unlikely to make much difference to the examination process. However, another expressed the opposite view, that the changes are significant because they will bring us in line with rest of world. This respondent went on to say that:

You get the feeling overseas patents are worth a lot more than Australian patents. The changes will make a big difference. From our point of view it will be a big change. We now need to submit patent searches and education of researchers will be important. However, the grace period will not make a big difference.

Other respondents also noted that whilst it is good to have a grace period in Australia, it will not really assist them because there is a lack of uniformity with regard to this provision world wide.

\section{The impact of patents on research and development}

Participants in each of the surveys were asked their views on the impact of patents on biotechnology research generally and on the impact of specific types of patents on their research. The results are summarised in Tables 5 and 6.

Respondents were asked the following question: do you consider that allowing the patenting of biotechnology inventions has a positive or a negative impact on research in this industry? They were also asked to provide comments in support of their views. Some respondents noted that their answer depended very much on the type of patent. Those 
answers are recorded in the "varies" column in Table 5 and Table 6. Some of their specific comments are reported more fully below.

Table 5: General views on the impact of patents on research

\begin{tabular}{|l|c|c|c|c|c|}
\hline $\begin{array}{l}\text { Industry } \\
\text { sector }\end{array}$ & $\begin{array}{c}\text { Positive } \\
(\mathbf{\% )}\end{array}$ & $\begin{array}{c}\text { Negative } \\
\mathbf{( \% )}\end{array}$ & $\begin{array}{c}\text { Varies } \\
\mathbf{( \% )}\end{array}$ & Nil (\%) & $\begin{array}{c}\text { No answer } \\
\mathbf{( \% )}\end{array}$ \\
\hline Companies & $33(68)$ & $1(2)$ & $8(17)$ & 0 & $7(13)$ \\
\hline $\begin{array}{l}\text { Research } \\
\text { institutions }\end{array}$ & $11(50)$ & $4(18)$ & $3(14)$ & 0 & $4(18)$ \\
\hline $\begin{array}{l}\text { Diagnostic } \\
\text { facilities }\end{array}$ & 0 & $5(39)$ & $3(23)$ & $3(23)$ & $2(15)$ \\
\hline
\end{tabular}

Table 6: Views on the impact of types of patents on research ${ }^{178}$

\begin{tabular}{|c|c|c|c|c|c|}
\hline Type of patent & $\begin{array}{c}\text { Positive } \\
\text { (\%) }\end{array}$ & $\begin{array}{c}\text { Negative } \\
\text { (\%) }\end{array}$ & Nil (\%) & $\begin{array}{c}\text { Varies } \\
\text { (\%) }\end{array}$ & $\begin{array}{c}\text { No answer } \\
(\%)\end{array}$ \\
\hline $\begin{array}{l}\text { Gene sequence } \\
\text { Company } \\
\text { Institution } \\
\text { Diagnostic } \\
\end{array}$ & $\begin{array}{c}21(43) \\
3(14) \\
1(8) \\
\end{array}$ & $\begin{array}{c}14(29) \\
6(27) \\
10(77) \\
\end{array}$ & $\begin{array}{c}3(6) \\
6(27) \\
1(8) \\
\end{array}$ & $\begin{array}{c}0 \\
3(14) \\
0 \\
\end{array}$ & $\begin{array}{c}11(22) \\
4(18) \\
1(8) \\
\end{array}$ \\
\hline $\begin{array}{l}\text { Research tool } \\
\text { Company } \\
\text { Institution } \\
\text { Diagnostic } \\
\end{array}$ & $\begin{array}{l}18(37) \\
8(36) \\
5(39) \\
\end{array}$ & $\begin{array}{c}15(31) \\
5(23) \\
3(23) \\
\end{array}$ & $\begin{array}{c}5(10) \\
2(9) \\
2(15) \\
\end{array}$ & $\begin{array}{c}0 \\
4(18) \\
1(8) \\
\end{array}$ & $\begin{array}{l}11(22) \\
3(14) \\
2(15) \\
\end{array}$ \\
\hline $\begin{array}{l}\text { Gene product } \\
\text { Company } \\
\text { Institution } \\
\text { Diagnostic } \\
\end{array}$ & $\begin{array}{c}28(57) \\
10(46) \\
2(15)\end{array}$ & $\begin{array}{c}6(12) \\
2(9) \\
9(69)\end{array}$ & $\begin{array}{c}2(4) \\
3(14) \\
0\end{array}$ & $\begin{array}{c}0 \\
3(14) \\
0\end{array}$ & $\begin{array}{c}13(27) \\
4(18) \\
2(15)\end{array}$ \\
\hline $\begin{array}{l}\text { Drug } \\
\text { Company } \\
\text { Institution } \\
\text { Diagnostic }^{179} \\
\end{array}$ & $\begin{array}{c}36(74) \\
14(64) \\
- \\
\end{array}$ & $\begin{array}{l}3(6) \\
1(5) \\
- \\
\end{array}$ & $\begin{array}{l}1(2) \\
2(9) \\
- \\
\end{array}$ & $\begin{array}{l}1(2) \\
2(9) \\
- \\
\end{array}$ & $\begin{array}{c}8(16) \\
3(14) \\
- \\
\end{array}$ \\
\hline $\begin{array}{l}\text { Diagnostic } \\
\text { Company } \\
\text { Institution } \\
\text { Diagnostic } \\
\end{array}$ & $\begin{array}{c}34(69) \\
13(59) \\
3(23) \\
\end{array}$ & $\begin{array}{c}2(4) \\
1(5) \\
5(39) \\
\end{array}$ & $\begin{array}{l}2(4) \\
2(9) \\
1(8)\end{array}$ & $\begin{array}{l}1(2) \\
2(9) \\
1(8)\end{array}$ & $\begin{array}{l}10(20) \\
4(18) \\
3(23) \\
\end{array}$ \\
\hline $\begin{array}{l}\text { Other }^{180} \\
\text { Company } \\
\text { Institution } \\
\text { Diagnostic } \\
\end{array}$ & $\begin{array}{c}7(14) \\
3(14) \\
0\end{array}$ & $\begin{array}{c}1(2) \\
0 \\
0 \\
\end{array}$ & $\begin{array}{l}0 \\
0 \\
0\end{array}$ & $\begin{array}{l}0 \\
0 \\
0\end{array}$ & $\begin{array}{c}41(84) \\
19(86) \\
13(100)\end{array}$ \\
\hline
\end{tabular}

\footnotetext{
${ }^{177}$ Percentages are out of the respondents that undertake research (13), not the total number of respondents (18).

${ }^{178}$ Percentages for diagnostics are out of the respondents that undertake research (13), not the total number of respondents (18).

${ }^{179}$ Diagnostics facilities were not asked this question.

${ }^{180}$ Includes targets, uses, formulations.
} 
Respondents were asked which types of patents are likely to have either a positive or a negative effect on biotechnology research. Those respondents whose answers are recorded in the "varies" column noted that the impact of specific patents on research varied depending on a whole range of factors. Some of their comments are reported below.

Specific comments from company respondents

Tables 5 and 6 clearly show that respondents in biotechnology companies generally view the impact of patents on their research positively. Indeed, survey respondents who provided specific comments generally considered that patents were essential for recovery of research and development expenditure and to ensure there was adequate incentive for investment in the industry. For example, one respondent stated that: "Patent protection must be sought for our company's survival.” Another suggested that in the absence of patents "...there would be no industry." One respondent offered the following comments on the benefits of obtaining patent protection:

1. It provides early tangibles of value;

2. The prosecution phase can provide early warning of any impending issues.

Of the eight respondents who offered a qualified answer to the general question about the impact of patenting on research, most were of the view that patents were positive. However, certain aspects of the patent system troubled them. For example, one respondent who considered that patents are fundamental to the industry nonetheless stated:

When properly adopted and implemented [the patent system] is positive and rewards innovation. If done in a reluctant haphazard manner - inconsistent, with no direction it has [a] negative impact. It is the best system [but] needs to be better used and administered.

Patents that were too broad were a concern to two of these respondents. One also referred to the length of time it took to have a patent granted. Another respondent's view was that they were undecided because "increasingly costs are becoming prohibitive for small companies - maintenance, prosecution and getting around [freedom to operate].” 
And finally: "where an inventive step is involved, the impact is positive. Where the patent deals with a mere discovery, highly negative.”

Interview respondents, on the whole, also expressed favourable views of the patent system as a means of protecting research results, although there were some reservations about the present system. The comment extracted below is typical:

I see a sound robust patent system as a very good thing... I have some concern with the one that we have - it is relatively costly and cumbersome. At the end of the day it will have a long-term impact on the biotechnology industry, especially in Australia.

Specific comments from research institution respondents

Table 5 shows that research institution respondents also generally viewed patents as having a positive impact on their research. A number of the survey respondents made specific comments in support of their viewpoints. One of the important considerations in the research sector is that the availability of patents encourages ongoing investment in research programs. One respondent summed up what seemed to be the general feeling of many respondents thus: "no patents = no investment!" Another said that “a strong intellectual property position is essential for future internal investment and required to attract commercial partners.”

Some respondents took a broad view of the issues associated with the impact of patents on research. For example, one person commented that "more inventions need to be commercialised because this is vital to Australia's long term growth and economy" and another said that patents have "an extremely positive effect as without patent coverage the commercialisation/establishment of a biotechnology sector is impossible.”

Generally, most respondents in the research institution sector seemed to accept patenting as a necessary part of the process of doing research, irrespective of its "effect" as such. For example, one respondent who expressed the view that all of the various types of patents have no effect on research qualified this by saying that:

Patenting is generally necessary if a discovery is to be advanced to a useful application. It is considered part 
of the process, as is publication, and as it is in any field of innovation.

I don't believe that patenting has no effect - it is just that the effect is multidimensional and should not be simply termed positive or negative - this presupposes there is a good and/or bad direction for research.

Others commented on the dual effect of patents. On the one hand they "promote technology transfer from the bench to the clinic and industry", but on the other hand they "restrict the use of the invention for further research by other parties and have the potential for companies to restrict a technology reaching the market.”

The positive view about patents in the research sector is supported by the interview data. For example, one respondent expressed the view that all patenting is pretty much positive. A number of interviewees in both the research and the company sector made more specific comments in relation to patent breadth and gene patents. These issues are discussed in the next two sections.

\section{Patent breadth}

There is extensive literature dealing with the optimal design of intellectual property rights. ${ }^{181}$ A subset of this literature deals with the effect of patent breadth on subsequent innovation, and debates the question of allocation of rights and co-ordination of later research. ${ }^{182}$

We were interested in exploring the views of our respondents towards these issues of patent breadth and its impact on innovation. To this end, we asked our survey respondents a question dealing with inhibition of research. Twelve respondents to our company survey answered that the grant of broad patents has an inhibitory effect on research (24 percent). Probably around two thirds of these undertook research activities that could be classified as relatively downstream. Six of the 18 respondents to the diagnostics survey considered that

\footnotetext{
${ }^{181}$ In the context of biotechnology, see, for example, J. Barton, 'Patent Scope in Biotechnology' (1995) 26 International Review of Industrial Property and Copyright Law 605.

${ }^{182}$ See, for example, Kitch above n130; Scotchmer above n141; R. Merges and R. Nelson 'Market Structure and Technical Advance: The Role of Patent Scope Decisions' in Jorde and Teece (eds) Antitrust, Innovation and Competitiveness (New York: Oxford University Press, 1992) at 185.
} 
broad patents had some sort of negative effect on research (33 percent). Seven of the 23 respondents to the research institutions survey said that they thought patent breadth had some negative impact on research (30 percent). ${ }^{183}$

A number of our interview respondents commented that the early patents in this area were exceedingly broad, particularly those granted in the United States in the early 1990s. However, there were various comments to the effect that the system appears to have worked itself out now, particularly in the United States where two important factors come into play:

- broad patents that have already been granted are not being upheld in the courts; and

- it is now much more difficult to get a broad patent than in the past.

The importance of being able to obtain broad patent coverage was recognised by many respondents. For example, one patent attorney commented that all clients want broad patents, but that she has to work within the realms of patent law. She confirmed that United States claims are much more strictly limited to what is disclosed in the specification than Australian claims and that it is possible to get a much broader scope of claim here. Most respondents who commented on the issue of patent breadth in the interviews noted that they continue to seek as broad protection as they could, with one upstream company respondent summing up the matter as follows:

It is difficult to answer questions about broad patents as it depends on where on the fence you sit... In my view the broader the patents the better. We are fairly aggressive in obtaining the broadest protection we can... But you have to obtain good patents. Many of patents at the moment are not sound enough. In the US you have to go through a lot to get a patent - the new requirements have really tightened up the system.

A licensing consultant also commented:

\footnotetext{
${ }^{183}$ One other respondent referred to the breadth of MTAs as being a problem rather than patents.
} 
Australian practice is to have the first claim as broad as possible and have an omnibus claim as the last claim. Some patents have failed on validity on everything but the omnibus claim. People want broad patents to freeze others out.

The risk to patent holders is that if claims are too broad they may be declared invalid if challenged. This carries with it various other problems, most particularly:

- for patent holders there may be an unwillingness to enforce patent rights for fear of losing the patent;

- for people wishing to work in the area of the patented technology, they may end up paying unnecessary licence fees, wasting resources in inventing around, ignoring the patent and risking infringement proceedings, or, at worst, abandoning a whole area of research;

- for the consumer, there may be delay in access to new products, and there may also be detrimental effects on cost, quality and choice of products.

However, some respondents did acknowledge that not all broad claims are necessarily invalid. As one respondent pointed out, where there is a truly novel invention it should be rewarded with a broad patent, and industry will generally respect such patents.

The obvious desirability for some of our respondents of obtaining broad patent protection has to be tempered by the effect of broad claims on others, particularly for follow-on research. ${ }^{184} \mathrm{~A}$ consideration of broad patents and how they affect innovation within the industry is therefore important, and there has certainly been concern within the biotechnology industry that broad claims on fundamental inventions could have an inhibitory effect on follow-on research. $^{185}$

\section{Impact of broad patents on research}

Given that a considerable number of patents granted in the last decade may be invalid, some respondents were content to ignore relevant

${ }^{184}$ J. Barton 'Patents and Antitrust: A Rethinking in Light of Patent Breadth and Sequential Innovation' (1997) 65 Antitrust Law Journal 449; R. Merges and R. Nelson, above n141.

${ }^{185}$ See, for example, Barton, ibid. 
patents and challenge their validity if approached by the patent holder. For example, one respondent involved in public sector testing and research stated that:

Some patents are a little broad and if challenged would not stand up. In some ways it doesn't matter if they are granted broadly. If you are infringing in a broad sense rather than narrowly, [you can] just let them pursue you.

A number of other respondents made similar comments. Many of them said that they often waited to see what the outcome was likely to be. It remains to be seen whether the more stringent patent requirements, more rigorous examination procedures and court interpretations of patents will be sufficient control mechanisms. Certainly most respondents thought it was likely that the breadth issue would be resolved through these mechanisms. A number of respondents referring to more recent, narrower patents found that inventing around these patents had become more straightforward. Patents that were broad but genuinely valid were not considered to be a problem given that most respondents were strong advocates of the patent system.

Interestingly, one respondent from a device company held the view that the court process was leading to broader interpretation of patent claims:

The court system tends to be very cyclical. If there is a fuss about broad patents they tend to be more narrowly construed. Then it will go the other way.

There is clearly a theoretical link between patent breadth and limitations on research, and it is often impossible to provide adequate rewards to both basic inventors and follow-on inventors. ${ }^{186}$ Despite this, most respondents were fairly optimistic about their ability to continue research despite the presence of broad patents, and felt that the problem of broad patents was dissipating as patent offices tightened up their examination procedures.

\footnotetext{
186 Scotchmer, above n141.
} 


\section{Gene patents}

The survey data presented in Table 6 clearly shows that all sectors of the industry have greater concerns about the potential for gene patents to have a negative impact on research than for any other types of patents. As with the survey data, a number of interview respondents expressed some doubt as to whether gene patents had a positive effect on research.

Perhaps predictably, respondents at the downstream end of the research-development continuum tended to have more negative views about upstream patents than respondents at the upstream end. For example, one respondent from a large pharmaceutical company stated that in his view upstream patents generally have a negative effect on research, particularly gene sequence patents. Another downstream company respondent expressed the view that inventors just surmise function in this area. They use homologies, claim the gene, protein, antagonist, antisense for gene therapy. In his view, although the effect may not be great now, this will have an effect 10-15 years down the track on the development of new therapies.

On the other hand, an upstream company respondent pointed out that the ability to patent function when the gene is known is essential to his company, and without it the company could not continue to exist. A number of respondents noted that there was a clear distinction in patenting of gene sequences between those sequences of unknown function and those of known function. One respondent said that:

It is unhelpful patenting the sequence for the sake of it. This is also the case where you have a sequence and some computational analysis giving putative function. However, when you know function and know that this is useful for disease identification and treatment then patents are appropriate. General sequence information is not particularly useful to a given outcome. An enormous amount of work is still required to produce a therapeutic or diagnostic. A sequence patent can make things terribly difficult later on, re no inventive step, etc. But once value has been added, e.g. by finding a mutation relating to a disease that may lead to a diagnostic test, etc then patents are essential. Without them, you can't get the invention commercialised. 
Some company respondents indicated that they did not perceive gene sequence patents to present any difficulties given that many gene sequences are in the public domain. Of course, this is not the case with all gene sequences, and we also had comments that it really depended on the research being done as to whether or not a patent was problematic. Most respondents agreed that where the function of a gene sequence had been identified, there was a sufficiently inventive step to make a patent an appropriate form of protection. In essence:

Gene sequence patents also have problems. The main issue is utility; there is nothing inventive about them. Really they just involve discovery. The real invention is finding a valid use, particularly in relation to homology claims. Utility will become an increasingly important requirement.

\section{Research tool patents}

A greater percentage of survey respondents expressed negative views about the impact of research tool patents on their research than for all other categories of patents. However, these views were not reflected in our interview data. The granting of research tool patents was not considered to be particularly problematic for a majority of our interview respondents. We extract a number of quotes below from interview respondents across all sectors of the industry. These quotes clearly demonstrate the lack of concern about enforcement of research tool patents in Australia.

This [research tool patenting] hasn't been a problem for us. In our research there is no patent we are aware of that we would infringe.

Access has never really been a problem. One exception is Roche's PCR technology.

Research tool patents and gene sequence patents do not create any problems for us.

I have never had to deal with patents over research tools. Never really come across a problem. This is may be because people are not aware that the patents exist. 
We try not to license in research tools - we have no current research tool licences, but we will have to in future. I do not like patents on research tools or gene sequences - it is difficult to track universities using them.

We have no real problems with access to enabling technologies.

We don’t have any licences to use research tools.

I haven’t done a research tool licence.

In our view this may be because industry participants in Australia may not yet have been faced with the aggressive enforcement practices of some research tool patent holders that have occurred in the United States, either because the relevant research tools have not been patented in Australia or because attention has not yet been focused on the Australian industry. Much of our data was collected before it became widely known that GTG was enforcing its junk DNA patents. Hence, views on research tool patents may well have changed in the last few months. In addition, we believe that views expressed in interview data on research tool patents arise in part because respondents may interpret the term "research tool" in the narrow sense. ${ }^{187}$

In conclusion, despite the negative views about the impact of research tool patents on research, we found hardly any evidence of research tool patents having an adverse impact on research and development. One upstream company respondent noted that that is probably because people are generally not aware that these patents exist. A number of respondents commented that research tool patents were notoriously difficult to enforce, and that this tended to decrease their value. Where complaints were made about research tool patents, these tended to be related to problems encountered in licensing-in, and the fact that holders of research tool patents frequently attempt to claim reach-through rights or royalties from licensees. These particular issues form the basis of much of our discussion in Results Chapters 4 and 5.

${ }^{187}$ See Context Chapter 3 for a discussion of the definition of research tool patents. 


\section{CHAPTER 2: TRANSFER OF TECHNOLOGY}

Intellectual property represents the most important asset of virtually all participants in the biotechnology industry. One of the reasons for this is that self-exploitation is not the norm across the Australian industry. In most circumstances biotechnology companies cannot rely on product sales to recover costs and secure profits. In this regard, the Australian industry conforms with the structure of the international industry, in that many players in the industry are in the business of value-adding to technology before transferring it further downstream. ${ }^{188}$ Hence, technology transfer is a crucial process within the industry.

Our results reveal that there are a number of strategies employed by owners of intellectual property when it comes to realising value on their technology. These strategies might include:

- $\quad$ setting up a spin off company which is assigned ownership of the intellectual property from the parent research institution or given an exclusive licence;

- exclusively or non-exclusively licensing with upfronts, milestone and/or royalty payments;

- entering into a collaboration, with specific provisions relating to ownership of existing and future intellectual property;

- co-ownership;

- assigning for a flat upfront fee or with future royalties;

- merger of entities or taking over another entity for the specific purpose of gaining a commercial advantage.

Choice of strategy will often depend on the nature of any existing collaborative or other arrangements. From the research institution perspective, it may be that a research collaboration is entered into between the institution and a private sector partner prior to the generation of any intellectual property. Or there may be a more formal collaborative network, for example the CRC network, in which case arrangements for ownership and transfer of technology are likely to have been specified in the head agreement.

\footnotetext{
${ }^{188}$ See further Nicol and Nielsen, above n4.
} 
In other instances, intellectual property may have been generated using public funding, in which case industry partners are sought for the purpose of transferring existing technology. The arrangements for dealing with intellectual property rights will often be quite complex, particularly when partners bring existing intellectual property (background intellectual property) into their relationship. Agreements will generally specify the arrangements for dealing with background and foreground intellectual property.

Private companies seeking to transfer their technology to downstream partners will also employ varying strategies, depending on the nature of the technology and a host of other factors. This chapter reports our findings relating to the issues associated with transfer of technology. We first report on the number and types of collaborations being entered into. We then report on the quantum of licensing-out of intellectual property

\section{SURVEY DATA ON COLLABORATIVE ACTIVITY}

\section{Collaborative activity: research institutions}

Our survey and interview data reveals extensive collaborative activity within all sectors of the industry (at least amongst our respondents). It also reveals that the nature of this collaborative activity often determined ownership of any existing intellectual property or intellectual property generated by the collaborative arrangement. All three sets of survey respondents were asked a series of questions about collaborations. Collaborations were particularly common within the research institution segment of the industry, but were widespread across the industry. Nineteen of the 23 research institution respondents reported being involved in collaborative arrangements (83 percent), with all of these respondents reporting that they were involved in at least two collaborations. Table 7 lists the number of collaborations per respondent and Table 8 provides details as to the nature of these collaborative activities. 
Table 7: Collaborative activity: research institution survey respondents

\begin{tabular}{|c|c|}
\hline Number of collaborations & Number of respondents (\%) \\
\hline 0 & $3(13)$ \\
\hline 1 & $0(0)$ \\
\hline $2-4$ & $5(22)$ \\
\hline $5-9$ & $3(13)$ \\
\hline $10-19$ & $4(17)$ \\
\hline $20-49$ & $4(17)$ \\
\hline$>50$ & $0(0)$ \\
\hline Number not specified & $3(13)^{189}$ \\
\hline No answer & $1(4)$ \\
\hline
\end{tabular}

Table 8: Types of collaborators and their geographical location: research institution survey respondents.

\begin{tabular}{|l|l|}
\hline \multicolumn{1}{|c|}{ Types of collaborators } & \multicolumn{1}{c|}{$\begin{array}{c}\text { Number and geographical } \\
\text { location }\end{array}$} \\
\hline $\begin{array}{l}\text { Small or medium sized } \\
\text { biotechnology company }\end{array}$ & $\begin{array}{l}\text { 14: 9 Australian; 3 not specified; } \\
\text { 3 Australian and overseas }\end{array}$ \\
\hline $\begin{array}{l}\text { Large company } \\
\text { (biotechnology/pharmaceutical) }\end{array}$ & 15: 3 Australian; 3 not specified; \\
1 Australian and overseas; 8 overseas
\end{tabular}

Note that most respondents indicated that they had several types of collaborations. Hence, the total number of collaborations reported in Table 8 is greater than the total number of research institution survey respondents. By far the greatest number of collaborations were with biotechnology and pharmaceutical companies (as well as other research institutions), with 14 respondents reporting that they had arrangements with small or medium sized companies, and 15 respondents reporting that they had collaborative arrangements with large biotechnology or pharmaceutical companies. This result is not surprising given the increasing trend of research institutions to commercialise their research results, and reflects a tendency to opt to partner with private companies that have the ability to commercialise that research. These results were backed up by the interview data that

${ }^{189}$ One of these respondents said that their institution had been involved in "many" collaborations. 
confirmed that research institutions increasingly seek industry backing and assistance in commercialising the outcomes of research projects.

\section{Collaborative activity: companies}

As a logical extension of the research institution data, high levels of collaborative activity were also reported in the company survey. Forty-three respondents to the company survey had entered into collaborations (88 percent). By far the majority of collaborations were with research institutions, although a considerable number of collaborative arrangements had been entered into with other companies. Table 9 lists the number of respondents who had entered into collaborations with various types of institutions, and the geographical location of those institutions.

Table 9: Types of collaborators: company survey respondents

\begin{tabular}{|l|l|}
\hline \multicolumn{1}{|c|}{ Types of collaborations } & \multicolumn{1}{c|}{$\begin{array}{c}\text { Number and geographical } \\
\text { location }\end{array}$} \\
\hline $\begin{array}{l}\text { Small or medium sized } \\
\text { biotechnology company }\end{array}$ & $\begin{array}{l}\text { 20: 9 Australian; 3 Australian } \\
\text { and overseas; 8 overseas }\end{array}$ \\
\hline $\begin{array}{l}\text { Large company } \\
\text { (biotechnology/pharmaceutical) }\end{array}$ & 20: 3 Australian; 3 not specified; \\
\hline Government & 0 \\
\hline Technology transfer company & 0 \\
\hline Research institution & $33:$ 24 Australian; 1 not specified; \\
& 6 Australian and overseas; 10 overseas 2 overseas \\
\hline CRC & 10: 10 Australian \\
\hline Other & 3 (hospitals, research clinics) \\
\hline
\end{tabular}

As with the research institution responses in Table 8, most company respondents indicated that they had more than one type of collaboration and hence the total number of collaborations reported in Table 9 is greater than the total number of company survey respondents. ${ }^{190}$

These results reflect the strong research base of Australian research institutions, and confirm that they represent an important source of basic research to many upstream and intermediate companies within the Australian industry. In contrast, many of the collaborations

${ }^{190}$ Note that two of the non-biomedical research respondents indicated that they had collaborations, one of which was with a large company and the other with a research institution and a small company. These data have been included in Table 9 (the other two survey respondents from this sector did not report any collaborative activity). 
entered into with other companies involved overseas rather than Australian companies. Again, the interview data presented below strongly supported these findings, suggesting that many Australian companies seek to export their technology to the larger overseas markets due to a lack of Australian funding opportunities.

\section{Collaborative activity: diagnostics facilities}

Significant collaborative activity was also reported by diagnostic facilities. Seven of the respondents to the diagnostics survey reported being involved in collaborations. Given that only 13 of the diagnostic facilities that we surveyed were involved in research activities, this represents more than half of diagnostic respondents involved in research of some kind (54 percent). Of the seven respondents, two reported only one collaborative agreement, three reported that they had between two and four agreements. One respondent reported over 50 collaborations and another did not specify a precise number but said that they had 'numerous' collaborations. These collaborations were entered into with a mixture of Australian and overseas entities, as indicated in Table 10.

Table 10: Types of collaborators: diagnostic facility survey results

\begin{tabular}{|l|l|}
\hline \multicolumn{1}{|c|}{ Types of collaborations } & \multicolumn{1}{c|}{$\begin{array}{c}\text { Number and geographical } \\
\text { location }\end{array}$} \\
\hline $\begin{array}{l}\text { Small or medium sized } \\
\text { biotechnology company }\end{array}$ & $1: 1$ Australian \\
\hline $\begin{array}{l}\text { Large company } \\
\text { (biotechnology/pharmaceutical) }\end{array}$ & $3: 1$ Australian; 2 overseas \\
\hline Government & $1: 1$ Australian \\
\hline Technology transfer company & 0 \\
\hline Research institution & $\begin{array}{l}4: 1 \text { Australian; 1 Australian and } \\
\text { overseas; 2 overseas }\end{array}$ \\
\hline CRC & 0 \\
\hline Other & 0 \\
\hline
\end{tabular}

As with the research institution and company responses in Tables 8 and 9, some diagnostic facility respondents indicated that they had more than one type of collaboration.

\section{Reasons for entering collaborative arrangements}

Collaborations are clearly an important component of the alliance activity of participants in the Australian industry, but how important is intellectual property as an impetus for collaborating? There many 
be many reasons why institutions and companies enter into collaborative arrangements, including: ${ }^{191}$

- obtaining revenues, for example from royalty payments;

- accessing vertical capabilities; ${ }^{192}$

- sharing products and technology;

- reducing manufacturing or regulatory costs; and

- attaining an international presence or gaining access to distribution networks.

Motivations for entering into collaborations will vary depending on where in the product development pipeline respondents sit, and whether they are importing or exporting technology. The opportunities available will also influence the style of alliance. Research institution participants, for example, enter into collaborations primarily to assist them in developing, commercialising and exporting their technology. This is confirmed by their answers to a question that asked them to specify their reasons for entering into collaborative arrangements. Those reasons were given as follows: ${ }^{193}$

- 12 said to secure access to intellectual property;

- 11 said to enable the commercialisation of research through patenting;

- 10 said to assist in meeting patent application costs.

- five did so for the purposes of obtaining industry funding or contract research. ${ }^{194}$

It is evident that research institutions rely heavily on industry assistance to enable them to commercialise research. The issues relating to technology transfer from research institutions to the private sector are canvassed in more detail below. Equally, however, obtaining access to intellectual property owned by another institution or company is an important basis for collaborating. Indeed, a vast

191 A Gutterman, Innovation and Competition Policy (London: Kluwer Law International Ltd; 1997) 125-7.

${ }^{192}$ Essentially this means that companies will seek to collaborate with companies at other stages of the research continuum to enable them to combine research capabilities.

${ }^{193}$ Where there may have been multiple reasons for entering a collaborative arrangement, respondents were asked to specify all of these reasons.

${ }^{194}$ Four other respondents gave answers - one said share skills/resources, one said strategic, one said useful application and the other said training. 
majority of respondents said that they entered into collaborative arrangements to secure access to intellectual property. Only two respondents gave it as the sole reason for entering into a collaboration. These results were confirmed in interviews with research institution respondents, discussed below.

Of the 43 company survey respondents who had entered into collaborations, 36 said that one of the reasons for doing so was to secure access to intellectual property owned by others (84 percent, 73 percent of total respondents). This result is not surprising given that many companies occupy intermediate and downstream research categories, and even those involved in upstream research frequently need to access intellectual property held by others. Four of the diagnostic facility respondents stated that the reason for collaboration was to secure access to intellectual property. Of the others, one had collaborated to secure Research and Development funds, one to 'get the work done' and one because of common interests with their collaborator.

\section{Collaborations and patent ownership}

The research institution survey respondents were asked to specify what arrangements had been made for ownership of any intellectual property generated as a result of their collaborations. Ownership issues will usually be determined prior to the commencement of the arrangement. For example, there may be a term that all intellectual property must be assigned to the industry sponsor. In other instances, ownership may be assigned to another independent company. These issues were canvassed more fully in interviews, and are discussed below in the two concluding sections of this chapter.

Four survey respondents said that the only arrangement they had was that their institution would own the intellectual property. In other cases, it would appear that a wide variety of arrangements had been entered into, and eight respondents listed more than one type of arrangement in relation to ownership. Eight respondents had entered into collaborations where newly-created intellectual property was owned by another participant in the collaboration, while 11 respondents had entered into some arrangements where intellectual property was shared between participants. 


\section{SURVEY DATA ON LICENSING-OUT ACTIVITY}

Survey respondents were also asked about the extent to which they licensed-out their intellectual property and the nature of the licences, that is, whether they were exclusive or non-exclusive. The results are summarised in Table 11.

Table 11: Number and types of out-licences: research institution and company results

\begin{tabular}{|c|c|c|}
\hline Number & Research institutions (\%) & Companies (\%) \\
\hline 0 & $8(35)^{195}$ & $24(49)^{196}$ \\
\hline 1 & $3(13)$ & $3(6)$ \\
\hline $2-4$ & $3(13)$ & $9(18$ \\
\hline $5-9$ & $2(9)$ & $1(2)$ \\
\hline $10-19$ & $0(0)$ & $0(0)$ \\
\hline $20-49$ & $1(4)$ & $1(2)$ \\
\hline$>50$ & $1(4)$ & $0(0)$ \\
\hline Number not specified & $2(9)$ & $5(10)$ \\
\hline No answer & $3(13)$ & $6(12)$ \\
\hline
\end{tabular}

In addition, two of the diagnostic survey respondents reported licensing-out activity, one of whom reported two exclusive licences. The other did not specify the precise number of licences.

In some respects, these results could be seen as surprising. Although 82 percent of research institutions and 76 percent of companies reported that they owned patents, only 52 percent and 39 percent respectively, reported licensing-out activity. However, we need to look at the respondents who reported no licensing-out activity more closely. In the research institutions survey, of the eight respondents who reported no out-licensing activity, one had no patents. In the company survey, of the 24 respondents who said they had not licensed-out any patents, nine said they did not own any patents.

\footnotetext{
195 Note that one respondent said that a licence deal was under negotiation but had not yet been completed.

${ }^{196}$ Note that four respondents said that a licence deal was under negotiation but had not yet been completed. Also that one of the companies that reported no licensing out of their patents was from the non-biomedical research sector (the other three survey respondents from this sector did not own patents).
} 
In Table 12 we provide short summaries of the status of the 15 company respondents and the seven research institution respondents who reported that they had patent ownership but no out-licences.

Table 12: Company and research institution respondents with patents but with no out-licences

\begin{tabular}{|c|c|c|}
\hline & Research & Patents \\
\hline \multicolumn{3}{|l|}{ Companies } \\
\hline 1 & Drug discovery & $\begin{array}{l}\text { Gene, tool, product, drug, } \\
\text { diagnostic }\end{array}$ \\
\hline 2 & Drug discovery & Drug \\
\hline 3* & Gene research, drug discovery & Gene, drug \\
\hline 4* & Drug discovery, cancer & Drug \\
\hline 5 & Diagnostic instruments & Tool, drug, diagnostic \\
\hline 6 & Diagnostics & Diagnostic \\
\hline 7 & Plant/ animal & Drug \\
\hline 8 & Veterinary, drug & Drug \\
\hline 9 & Drug discovery & $\begin{array}{l}\text { Research tools, synthetic } \\
\text { processes }\end{array}$ \\
\hline 10 & Devices & Devices \\
\hline 11 & Devices & Devices \\
\hline 12 & Devices & Devices, diagnostics \\
\hline $13^{*}$ & Devices & Devices \\
\hline 14 & Cancer & Drug \\
\hline 15 & Not specified & $\begin{array}{l}\text { Gene, drug, diagnostic, } \\
\text { manufacture }\end{array}$ \\
\hline \multicolumn{3}{|l|}{$\begin{array}{l}\text { Research } \\
\text { institutions }\end{array}$} \\
\hline 1 & $\begin{array}{l}\text { Gene, drug, vaccines, } \\
\text { bioinformatics }\end{array}$ & Drug \\
\hline $2^{*}$ & Drug & Drug \\
\hline 3 & Protein & Treatment \\
\hline 4 & Gene, cancer, protein, drug & Drug \\
\hline 5 & Gene, protein & Gene \\
\hline 6 & Enabling & Tool, diagnostic \\
\hline 7 & $\begin{array}{l}\text { Gene, cancer, virus, protein, } \\
\text { drug, enabling, bioinformatics }\end{array}$ & $\begin{array}{l}\text { Gene, tool, product, drug, } \\
\text { diagnostic, + others }\end{array}$ \\
\hline
\end{tabular}

Companies and research institutions marked with an * stated that they had licence agreements under negotiation.

It is possible that a number of the companies listed in Table 12 may be capable of bringing their products directly to market without the need to license-out. However, in several instances there may be an issue as to why a respondent's patents have not been licensed-out. For example, we would expect company respondent 1, who indicated they 
held 11 families of patents, to report some licensing-out activity. Similarly, it is perhaps surprising that company 14 reports no licensing-out activity. These figures are undoubtedly reflective of an industry in a growth phase. Some respondents may be endeavouring to get to the point where they are in a position to license-out, but may not have reached this point yet. Other respondents may exploit their technology themselves. Hence, the figures on the extent of licensingout activity should be read with some caution once the characteristics of companies who haven't (or apparently haven't) licensed-out are investigated.

With regard to the research institutions listed in Table 12, although at least one said that they were open to licensing-out, it is likely that others utilise alternative strategies for transfer of patented technology. Two institutions noted that they had a number of collaborations, and these may well involve sharing or transfer of ownership rather than licensing-out. In the alternative, the institution may follow the strategy of forming a spin-off company to commercialise patented inventions instead of licensing-out.

We can conclude that most patent holders are able to find ways to license-out their technology or to find other means of transferring their technology to other sectors of the industry. This conclusion is supported by our interview data. Many interview respondents confirmed that they were actively involved in licensing-out their technology, or were in the process of attempting to find parties interested in licensing their technology. Most respondents who had not entered into licensing agreements said that they intended seeking licensing-out opportunities when their technology was at a marketable stage.

Nevertheless, respondents from all sectors repeatedly emphasised the difficulty of moving their technology out, and the long, drawn out process entailed in negotiating licences. Respondents from research institutions, in particular, stressed that the plethora of opportunities available to companies meant that they had difficulty making their technologies and products an attractive investment to companies. Even respondents from companies who were seeking to license-out, said that they had to work hard to attract commercial interest. Other studies support these findings. For example, Monotti and Ricketson point out the difficulty for patent holders in finding an appropriate 
licensee who can pay an appropriate royalty and will pursue development of the invention to bring the product to market. ${ }^{197}$

\section{LICENSING, ASSIGNMENT AND MERGERS}

Our interview data suggests that participants in the Australian industry often lack the resources and infrastructure to self-exploit intellectual property, particularly in the area of drug development. However, this is less of a problem in other industry sectors, particularly in the device sector and in the non-human research sector. An inability to self-exploit is not in itself problematic provided that there are sufficient opportunities available for transferring technology. Few of our interview respondents who had intellectual property said that they didn't exploit it because nobody would take it up, but in many cases the process of transferring technology contained many obstacles. The remaining question is which of the strategies for technology transfer is most beneficial to the Australian biotechnology industry.

Interview respondents from both the public and private sector generally preferred licensing-out over assignment as a form of technology transfer. Many collaborative arrangements had licensing components, and many agreements involved considerable complexity. Whereas a licence gives a licensee the right to exploit aspects of the patented technology without infringing the patent, an assignment transfers ownership of the patent. Both licensing and assignment may be important components of collaborative relationships. Which strategy to adopt will depend on a number of factors including:

- the importance of the technology to the patent holder;

- the nature of the technology;

- the likelihood of finding alternative investors; and

- the negotiating strength of the parties.

Licensing-out of intellectual property has a number of advantages over assignment. Perhaps most importantly, licensing allows the patent holder to retain control of the intellectual property in terms of ensuring the technology is exploited, and in terms of rights to

197 A. Monotti and S. Ricketson Universities and Intellectual Property (2003) Oxford University Press, Oxford at para 9.48 (hereafter Monotti and Ricketson). 
improvements that are derived from the licensing relationship. For example, a licensing consultant said that:

Assignment is not common and I don't like to advise clients to do this because they lose control. This is particularly important when there is a royalty component and value adding through improvements. Generally a licensor will want a term that improvements are theirs or are licensed back royalty free. You don't get this if you assign.

Licence deals also assist patent holders in maintaining a more substantial patent portfolio, as well as the opportunity of an ongoing revenue stream.

From the perspective of those respondents acquiring technology, a number said that they prefer to acquire it through assignment where possible, because of the increased control it gives them over exploitation of the technology. Other respondents preferred to licence-in technology because they were cautious about their ability to properly value technology for the purposes of assignment. Licensing allows valuation to be deferred to some extent. However, assigning-in has a major advantage over licensing-in in that it allows total control over the exploitation of the technology. A number of respondents suggested that this prompted them to make efforts to overcome any problems they encountered in valuation. Most respondents who were engaged in intermediate or downstream research agreed that their best position was to be able to exert as much control over the exploitation of the technology as possible, generally through an assignment or an exclusive licensing arrangement. The patent holder may dictate the decision to some extent, although the relative bargaining power of the parties will be an important consideration.

Interview respondents generally reported being involved in both assignment and licensing deals. One respondent described an "active and dynamic" licensing environment within Australia. Certainly a large number of our interview respondents were involved in licensing activity, with most of them reporting that they had been involved in licensing deals. Those that hadn't, in most cases, were approaching the point where they were looking for licence opportunities. 
Assignment appeared to be utilised far less frequently than licensing. However, it does represent an important method of overcoming ownership problems. For example, some research institution respondents indicated that where students were involved in researching a particular area, assignment provisions were crucial to enable patented technology to be marketed free of difficulties in relation to title or ownership. ${ }^{198}$

We were also interested to ascertain the extent of merger activity within the industry. It has been observed that there is a trend toward convergence within the international biotechnology industry, both in the biomedical and agricultural sectors. ${ }^{199}$ Accordingly we asked a series of questions on merger activity on the company survey. Nine of the 49 respondents to the company survey had acquired another biotechnology (18 percent). All of these respondents reported acquiring patents as a result of the acquisitions, however this was not necessarily the impetus behind the decision to acquire another company. There may be many reasons why a merger takes place, and we asked these respondents to identify the reasons for their acquisition. They characterised them as follows:

- seven said they acquired some competitive advantage;

- $\quad$ seven said it enabled them to gain access to other markets;

- five said it boosted their product pipeline;

- two said it allowed them to continue research blocked by patents; and

- one required an injection of capital.

Clearly, merger activity is not necessarily indicative of an attempt to obtain intellectual property, but it may have the effect of giving control over a significant portfolio of intellectual property.

\section{TECHNOLOGY TRANSFER ISSUES FOR RESEARCH INSTITUTIONS}

As noted above, a range of strategies may be employed by intellectual property owners to transfer their technology for downstream

\footnotetext{
198 This issue is discussed in more detail in Results Chapter 3.

199 See, for example, the latest international Ernst and Young report: Ernst \& Young 2003, above n1.
} 
exploitation. In this section we look at some of the specific issues for research institutions in transferring their technology. Some of the most important strategies employed in this sector include licensingout and assignment to existing companies or creating spin off companies for the specific purpose of exploiting a particular form of technology. Where a spin off is created it is likely that the technology will either be exclusively licensed or assigned to it.

One big threshold problem that was highlighted by research institution respondents was the lack of any real mechanism for searching out commercial partners. However, a licensing consultant pointed out that mechanisms are being developed to provide assistance in this area. For example, there are Internet bulletin boards that advertise technologies available for licensing. For example, the Dupont family runs one and the big accounting firms also have them. Apparently, the Licensing Executives Society is also talking about putting up a worldwide bulletin board.

\section{Technology transfer strategies}

Respondents emphasised the importance of being flexible in technology transfer negotiations. One technology transfer officer said that her institution uses various strategies, including assigning to spin offs, licensing and collaborations. A number of research institution respondents said that the favoured mechanism for exploitation of intellectual property is to create a spin off company as a vehicle for ownership. The institution then assigns or exclusively licenses intellectual property to the company and takes an equity share in the company. A Report to the Prime Minister's Science, Engineering and Innovation Council in 2001 strongly supported the strategy of forming spin offs. ${ }^{200}$ The Report noted at page 3 that:

If we can grow 200-250 more Australian researchbased companies like five of those shown in this report over the next five years, the prize would be around AU\$20 billion added to our annual export earnings. Australia would be well on the way to reducing the national debt and the cost of servicing it.

Unfortunately, these figures fail to reflect the high failure rate of biotechnology products, particularly drug-related products.

${ }^{200}$ PMSEIC, above n120 at 3. 
Companies that are reliant on the success of single products have a high risk of failure. Monotti and Ricketson note that although they have no data on the survival rate of spin offs they are prone to failure because of a range of problems, including economies of scale, entering into inappropriate alliances and developing high-risk embryonic technologies. ${ }^{201}$

One respondent said that he saw biotechnology as potentially heading down the same path as information technology, with a large number of overlapping start-ups and huge portfolios of licensing deals. He said that biotechnology is not there yet but heading that way. A number of company respondents reported that negotiations involving universities are slower than with other companies, because of "the bureaucratic wheel of the university". It was generally accepted that things are getting better, although some comments were made that scientists and university administrators do not often appreciate the difficulties involved in dealing with a number of different parties. Delays are exacerbated when a number of parties are involved in negotiations. A technology transfer company respondent gave one example of:

a project funded by government. Intellectual property was licensed to one company. The company didn't want the intellectual property at the end of the project. It had to be transferred to someone else and the university had to sign off on it. This has been going on for a year, with four parties involved.

One respondent mentioned that poor negotiating strategies in the past can have long term effect into the future. If too much intellectual property is given away and obligations with regard to background intellectual property and improvement intellectual property are tied too closely to the commercial partner, it may preclude further negotiations with other commercial entities well into the future. If, as in the case of this respondent, the commercial partner runs into financial difficulties the implications for the development of past intellectual property and for future research could be serious. This is one good reason for having a large pharmaceutical company as a partner; their financial position is generally much more secure than that of small Australian biotechnology companies.

${ }^{201}$ Monotti and Ricketson, above n197 at paras 9.59-9.68. See also P. McGinness Intellectual Property Commercialisation: A Business Manager's Companion (2003) Buttterworths, Sydney, Chapter 21 'Spin-Offs' at 309-320. 
Various respondents confirmed that one of the biggest problems in Australia is naivety in bargaining, particularly for research institutions. Even if they have good technology they are not good at the bargaining side, particularly because they lack deal precedents. However, a large pharmaceutical company respondent did acknowledge that institutions are becoming more patent aware. He did not see this as a bad thing because research needs to be protected by good intellectual property. However, the difficulty that arises from this is lack of consistency in intellectual property management strategies across institutions (with Melbourne University being particularly problematic - but not insurmountably so) and overvaluation. He saw this as being a particular problem in Australia because it is not as "savvy" as other places. Valuation tends to be based on an optimistic view of success.

\section{Assignment and licensing}

It appears that assignment was a favoured technology transfer strategy for research institutions early in the biotechnology revolution because it was seen to reduce risk. By handing over all rights to the invention for an upfronts fee this essentially removed all risks. However, the cost is that it also removes all control. One respondent noted that if the assignee fails then the intellectual property is lost. More recently, there has been a growing trend for research institutions either to retain ownership of their intellectual property and license-out to industry or to form a spin off company for the purpose of commercialising a particular product.

Two of the benefits of licences from the research institution perspective are that if ownership remains with the institution it can still be counted in the institution's intellectual property portfolio, and that licences are not public documents whereas assignment must be publicly disclosed. On the other hand, from the company perspective, ownership of intellectual property is essential to ensure return on investment in the research project. One respondent from a device company expressed the view that the main headaches that arise in collaborations his company has are ownership and disclosure of information issues. This was echoed by a number of company respondents from all stages of the development continuum, and was a matter that most sought to resolve early in the collaborative relationship. 
One company respondent noted that in 99 out of 100 cases, the research institution retains ownership, either independently or with the industry partner as a co-owner. This respondent noted further that if the company contributes funding to the research, then co-ownership is expected. Industry partners are understandably reluctant to advance funds for research without some assurance that they would realise a return on their investment. It appears that shared ownership is becoming increasingly common as research institutions assert their rights to technology developed as a result of collaborative ventures, although they may still face some opposition from private sector companies. This comment from a university technology transfer officer sums up the position of many research institution respondents:

We may have collaborations to do a piece of work in which case the technology is shared. We consider all options and focus on what is best for the project. We want to make sure that we get a good deal. I don't get involved in these negotiations. They are pretty hard headed.

A number of respondents reported that where there is industry funding of a research and development program the company sponsor will at least require a right of first refusal to intellectual property and know how derived from the project. This may become problematic when an institution is funded to carry out research relating to improvements to existing intellectual property. One respondent commented on the particular difficulties that may be encountered in negotiating who has rights to the improvements on existing intellectual property owned by the company sponsoring the research, particularly when they are separately patentable. The problems associated with rights to improvement and rights to future intellectual property more generally are discussed in detail in Results Chapter 4.

One of the crucial licensing decisions is whether to grant an exclusive or a non-exclusive licence. The nature of the licence would seem to depend very much on the technology. For example, it is likely that gene patents will be non-exclusively licensed, unless they are exclusively licensed to a spin off company which then nonexclusively sub-licences. Drug-based licences tend to be exclusive. In many cases there will be different licences for different aspects of the technology: some components may be non-exclusively licensed whereas other components are exclusively licensed. We discuss the 
issues associated with exclusive and non-exclusive licensing more fully in Results Chapter 4.

\section{TECHNOLOGY TRANSFER FROM UPSTREAM TO DOWNSTREAM INDUSTRY SECTORS}

In this section we turn our attention to the specific issues for upstream and intermediate companies in transferring their technology further downstream. Challenges exist both for researchers and companies wanting to move their technology or products out, and for companies seeking to add value by further developing technology. As a global market, biotechnology has some unique features. Most notably, a vast majority of the private sector players are small to medium-sized companies, and the business of biotechnology is very distributed. The cumulative nature of biotechnology research means that intellectual property needs to be assembled in order to develop a platform. As one company respondent commented, "you need to license in three patents to get one out.”

\section{Technology transfer strategies}

Few participants in the industry have the ability to "go it alone." Many industry participants in Australia are involved in drug discovery but very few produce the final products. As one respondent put it "we will not produce a product for anyone ever". The reasons generally given are both that the costs of clinical trials are simply too high and that it would be wishful to think that a small Australian company could compete with a big multinational. Thus, "it is better to get in bed with [large pharmaceutical companies]”.

One consequence of this is that most Australian companies are unlikely to raise revenue from product sales, either at present or in the foreseeable future. On-licensing to more downstream companies is far more likely to be the primary source of revenue for most companies. As such, licensing-out of intellectual property and associated know how would appear to be the most important strategy for many Australian biotechnology companies. Although the terms of technology transfer agreements may frequently be contentious, it is probably fair to say there were few cases where technology transfer did not proceed at all once negotiations had commenced. 
One industry sector that is a notable exception to this licensing trend is the device sector. Device companies do not tend to license-out their technology but supply directly to end-users. Interestingly, some of the most successful companies in the Australian biotechnology industry are device companies. Two companies, Cochlear and Resmed, have been particularly successful. ${ }^{202}$ This success may in part be attributed to the lower regulatory requirements for devices when compared with drugs. These same arguments could also apply to the diagnostics sector of the industry, for the same reasons. However, the two respondents to the diagnostics survey who reported that they owned patents both said that they licensed-out their technology.

\section{Attracting downstream partners}

In order to survive and expand, upstream drug development companies must ensure that they have projects that are attractive to downstream companies. Ideally, these companies are looking to add value to research institution inventions and to sell or license their projects to one of the large multinational pharmaceutical companies. However, large pharmaceutical companies are only interested in potential blockbuster drugs that are likely to be worth AU\$1 billion. Although the large pharmaceutical companies are constantly trawling for potential new products, they can pick and choose from many options. Consequently, if there are any problems with a particular project it is unlikely that it will be chosen. On the other hand, some respondents noted that if the technology is good enough there will be a willingness to work through any impediments that stand in the way of product development, irrespective of how intractable they might appear. Nevertheless, even when this is the case the route from invention to product is not an easy one. In response to the question "if there is a good invention is it easy to commercialise?” one research institution respondent answered:

No it is an extremely hard slog. It takes a lot of work on the part of the researcher and a lot of institution resources. In one case it split the lab because a spin off company was formed. This took a huge amount of time

\footnotetext{
${ }^{202}$ See, for example, M.N. Barber 'Research Priorities for Australia: Setting Our Future' Telstra Address to the National Press Club, Canberra, 26 June 2002, available at: http://www.science.org.au/academy/media/26june02.htm (accessed 20 November 2003).
} 
and good people were lost to the spin off company in the process.

Many respondents from companies seeking to maximise the commercial potential of their technologies or products commented on the difficulties in attracting partners and reaching a negotiated agreement. In many cases, respondents felt they had little choice in selecting partners, and characterised the market as a "buyers' market”. Some companies have managed to attract attention and garner an international presence, but a considerable number are still grappling with finding partners interested in their technology. The main issues that arise for these respondents is gaining and maintaining exposure among investors, and communicating the marketability of their product.

In relation to intellectual property, problem areas were identified as unclean patent ownership, uncertain validity and insufficient scope. Each of these problems might make a particular project unattractive to potential downstream licensees. For example, one respondent reported that clean chain of title is essential because "if intellectual property is not clean, pharma will not touch it”. These intellectual property issues form the basis of much of our following discussion. However, it must be acknowledged that there is a whole range of other problems, not associated with intellectual property as such, including disease coverage, insufficiency of clinical data, etc.

Those respondents involved in research on drug targets say that they now have to functionally validate targets themselves in order to attract downstream partners. Those involved in drug development reported that to give their products maximum marketability they must produce as much clinical data as possible in house, preferably well into phase II clinical trials. One respondent reported that his company develops to proof of concept in phase II clinical trials before looking to licenseout. However, another commented that it is necessary to go even further: proof of concept was enough in the old days but now the bigger companies want toxicology to be done and completion of phase II trials. Clinical data obviously will increase the opportunity for attracting large pharma interest and it also the value attached to licences. One respondent noted that:

A lot of biotechnology companies take products into phase III then make a huge amount of money from pharma. Royalties of up to 20 percent are being 
offered. This is really worthwhile as you don't have to pay for any more development and manufacturing costs. If you are before phase III and are offered 10 percent you feel like you are being ripped off. Probably in the end you can get around 15 percent and aim for a large up-front fee. If you get to phase III you are looking at earning AU\$20-30 million up front. The upfront fee is a very important component of the deal. You don't get this if you licence-out too early.

On the other hand, another company respondent commented that their company had never been as far as phase III because of the expense. The involvement of large pharmaceutical companies is necessary to provide funding and resources and also to provide the knowledge base to comply with United States drug registration requirements. It would seem that even the largest Australian companies would baulk at undertaking phase III trials because of their enormous expense.

There is considerable risk to small companies in investing in clinical trials. If a particular product cannot ultimately be on-sold or licensed the investment in it might be lost. One respondent commented that the odds of a product making it to market are pretty awful, probably around 20:1. It takes a number of products for one to make it through to the end. Hence, the odds are very much stacked against oneproduct companies. As one respondent put it:

Start up companies generally rise and fall by a single product. There is not a great deal of success. All tend to float a little early. They often have a drug that is very active in vitro but to make it into a product is very difficult. They don't factor in costs and run out of money. They also have problems with patents. They need to create a picket fence around their technology with a range of patents: formulations etc. They must have this to get deals with international companies.

Even when industry participants are looking for partners other than large pharmaceutical companies, they still tend to favour international players, particularly United States companies. For example, one respondent from an upstream biotechnology company commented that their company tends to license-out to small United States biotechnology companies engaged in drug screening. Another respondent noted: 
For licensing-out our main market is the US. I have just taken my $5^{\text {th }}$ trip in 7 months. I have been talking to biotechs, gene therapy companies and pharmas, across most of the biotechnology industry. Our profile is slowly increasing. We mainly do strategic alliances and freedom to operate agreements. The terms are variable. There are six different market segments. One of them is retail - supply of reagents to biotechs. These agreements tend to be exclusive. Drug companies using our technology in house go for nonexclusive arrangements. Companies doing research on gene therapies for cancer go for exclusive licences based on disease gene targets.

However, one of the big problems identified for Australian companies is lack of the ruthlessness that many of their international counterparts have developed. Hence they tend to cave in too easily when negotiations become difficult. In part this may be because they don't appreciate the value of what they are acquiring and giving.

In some circumstances organisations may enter into horizontal licensing arrangements with competitors. For example, one respondent commented that:

In relation to one of our areas of research, we have a number of competitors with products on the market. Part of our licensing strategy is to approach them. They tend to look at known targets whereas we are looking at a mutation we have discovered. This market is significant.

However, this mechanism for earning licensing income would appear to be the exception rather than the norm.

\section{LICENSING-IN}

Issues associated with licensing-in of technology form the basis of much of our further analysis, particularly in Results Chapters 4 and 5. We note some of the key issues raised by respondents here. 
Many respondents confirmed that often they needed to license-in technology to avoid infringing existing patents in an area. In most cases, due diligence performed prior to the commencement of research in an area enables identification of patents that might be infringed if research proceeds, and most researchers become aware at this stage of other patents in the area and made decisions about whether or not licences would be required.

Where access to a patent was necessary to enable research to proceed, approaching a patent holder to request a licence was first choice of tactic for some of our interview respondents, while a significant number of other respondents listed it as their last choice. Licensing agreements were entered into at various stages of the research process. Many respondents sought licences directly after conducting due diligence. On the other hand, some respondents reported proceeding with research and waiting to be approached by a patent holder before entering into negotiations for a licence. ${ }^{203}$

In many cases, deciding whether or not to approach a patent holder for a licence depended on how receptive the patent holder was likely to be to negotiations. Many respondents commented that whether or not they would contemplate seeking a licence depended to a large extent on the identity of the patent holder. A number of respondents from small to medium-sized biotechnology companies admitted that if they learned a patent to which they required access was owned by a large multinational, they would think twice about seeking a licence.

\section{LICENCE TERMS}

Most respondents engaged in licensing agreed that they licensed on the most favourable terms they could negotiate. A number of terms were referred to consistently by respondents as being the subject of debate in negotiations: ${ }^{204}$

- fees. Licence fees were consistently referred to by our respondents as being the most difficult terms to settle in

\footnotetext{
${ }^{203}$ Sometimes in doing so, a blocking patent situation might arise so that a crosslicence deal becomes attractive. In this case, the researcher will be in a stronger position when bargaining: see further the discussion on cross-licensing in Results Chapter 7.

${ }^{204}$ See also ALRC, above n18 at 155-6.
} 
licence negotiations. We discuss issues associated with fee structure and quantum below;

- reach-through rights to future inventions. These terms are seen as being particularly likely to raise access restriction and anticommons issues, and are discussed in detail in Results Chapters 4 and 5.

- exclusivity. One of the crucial licensing decisions is whether the licence should be exclusive or non-exclusive. The nature of the licence would seem to depend very much on the technology. For example, it is likely that gene and other research tool patents will be non-exclusively licensed, unless they are exclusively licensed from a research institution to a spin off company which then non-exclusively sub-licences. Drug-based licences tend to be exclusive. In many cases there will be different licences for different aspects of the technology: some components may be non-exclusively licensed whereas other components are exclusively licensed. We discuss the issues associated with exclusive and nonexclusive licensing more fully in Results Chapter 4 because exclusive licensing could raise access issues, particularly if the technology is foundational in nature;

- reversionary rights. Many interview respondents, particularly those from research institutions said that they insisted on reversionary rights to any intellectual property they licensedout which was not subsequently utilised. Revocable licences were common amongst research institution respondents, particularly where the arrangements were exclusive. The justification for this requirement is because of problems encountered in the past with licensees failing to develop licensed technology. Research institution respondents stressed importance of a clause specifying reversion rights if the licensee fails to adequately exploit the invention within appropriate time frames. It seems that some of the early agreements failed to provide reversionary rights in such situations. This also is a problem for private sector companies. A number of respondents referred to the example of the flu drug Relenza, developed by Biota Holdings and licensed to Glaxo SmithKline; ${ }^{205}$

- performance clauses. These were referred to by a number of respondents. These may take several forms, for example, an

\footnotetext{
${ }^{205}$ Glaxo scaled back on marketing the drug following poor initial sales, causing disastrous consequences on Biota's share prices.
} 
exclusive licence may revert to a non-exclusive licence if the invention is not worked, and/or the invention may revert to the patent holder. In some instances, determining whether the licensee has expended their best efforts in exploiting or commercialising the invention may be problematic. This is a significant transaction cost associated with licensing;

- retention of right to research. Research institutions, in particular, often attempted to retain the right to research and work the invention, and in many cases this right will be granted provided there is no commercial purpose. In these circumstances, any attempt to commercialise a product may cause any resulting intellectual property to flow straight to the licensee;

- indemnities. Indemnities, particularly where materials had been transferred were not generally referred to as being problematic, although other studies have found that this is a particularly prominent issue. ${ }^{206}$ One of our respondents did refer to difficulties presented by requests for indemnities when licensing-in;

- title to the patent. Title can be an issue for potential licensees, and many interview respondents stressed the importance of clean title to patents before they were prepared to enter into licensing negotiations. In the absence of clean title, entering into an agreement became too problematic. In addition, defining the licensed patent may be difficult where there is a mixture of applications and registered patents.

- material transfer agreements (MTAs). These have their own sets of issues. MTAs, particularly where verbal, can prove problematic as one technology transfer officer pointed out:

Where there is a commercial interest the problems tend to be in terms of materials (reagents etc.). They tend to be given to us as gifts with no real obligations. If there is no written agreement the difficulty is in knowing what the terms are. MTAs are standard - we make sure there is an MTA when material goes out. A lawyer goes through the MTA when material comes back in. We give this special attention. If anyone gives us materials,

\footnotetext{
${ }^{206}$ See NIH, above n37 at 10. For example, problems may arise where universities are requested to provide indemnities against liability arising from the use of patented research tools and materials.
} 
they retain ownership of them and any intellectual property they generate. For example, we might put a patented gene sequence into another vector, They own the vector, and so intellectual property ownership is a real issue. It is generally nonnegotiable but there are ways around this.

- length of term of licence. The duration of the licence may become an issue, as may the method of determining the duration;

- field of use restrictions. Common restrictions include prohibitions on sharing research tools or materials with other researchers or institutions, using materials for commercial purposes, or using them for research outside the particular project for which they are licensed. ${ }^{207}$ From our interviews, it would appear that restrictions of some kind arise in a considerable number of agreements. One licensing consultant, in particular referred to such restrictions as being problematic in a considerable number of negotiations. Field of use restrictions are common, particularly where licences are nonexclusive, but he considered that restricting the field can be quite difficult. One CEO from a research institution considered terms dealing with the scope of the licence to be a real sticking point, stating that:

You could have a licence to one company for one thing, [and to] another company for another. For example, where there is an antibody and a small molecule, the first company [would want] both because the other company is their competition. But they are often split. Also territory - can have rights to single markets.

One study also raised the concern that scientists in public sector institutions may find it difficult to abide by these terms given that they are unaccustomed to having restrictions imposed on the manner in which they deal with materials; ${ }^{208}$

- dealing with infringement. One sticking point in negotiations will sometimes be who is responsible for enforcement of the patent; and

\footnotetext{
${ }^{207}$ See NIH, above n37 at 9.

${ }^{208}$ Ibid.
} 
- right to sub-license. Some respondents said that they would insist on the right to sub-license if they were seeking a licence, and in many cases they successfully bargained for the inclusion of this term.

\section{Fee structure}

Fee structure is hugely variable and depends on a whole range of factors, including:

- the technology: products or processes; broadly applicable platform technologies or specific research tools. For example, one respondent reported that in general research tool licences will be non-exclusive with a small up front fees and low, if any, royalties;

- the technology: core or non-core. If the technology is non-core then it is likely that it will be licensed-out for a small upfront payment. If core technology is licensed-out at all it will be at a much higher rate and it is likely that some control will be maintained over future developments of the technology in the form of both milestone payments and royalties;

- the parties: competitors or collaborators. For collaborators it may be desirable to maintain the ongoing relationship, whereas for competitors a one-off payment is more likely;

- the relative bargaining power of the parties. It is generally recognised that public sector patent holders tend to start from an inferior bargaining position. However, this is not always the case. In determining the appropriate fee structure, much depends on the strength and novelty of the technology, and, of course, a thorough understanding of these factors by the person negotiating the licence;

- the financial strengths or weaknesses of the parties. Some respondents emphasised the importance of being fully briefed on the financial status of the other party prior to the commencement of negotiations. It will not be desirable to maintain an ongoing relationship if there is some doubt about the financial viability of the other party to the negotiation.

The goal of most research institutions is to recover research and patenting costs. This is also the case for the smaller research and development companies. One respondent noted: 
We want a return on our investment. We look at research costs, licence costs, assignment costs, ongoing patent maintenance costs. We want to recover all of this and make a return.

For licensees, on the other hand, fees will be dependent on the downstream value of the product or process and not on the costs incurred in bringing it to that particular stage. "The other side measures the deal in terms of future value - what they are prepared to pay.”

In general there will be upfront, milestone and royalty components. All respondents reported that they wanted some form of upfront payment. When licensing-out, research institutions tend to take riskaverse strategies, for example preferring higher upfronts payments and lower royalties. For them, a one off upfront fee may be the preferred option because it removes the risk factor. The fluidity of the market structure is a factor that encourages some company respondents to prefer one-off payments rather than continuing royalties. One respondent commented on the high level of convergence and change in company structures and the difficulty this created in re-establishing your rights.

A large pharmaceutical company respondent commented that in his experience early clinical phase licensing is likely to have a milestone component in it as well as royalties. Early research tends to be more milestone focused, later more royalty focused. However, none are purely one or the other. A milestone component is seen as important for encouraging ongoing development of the licensed technology. Milestones are particularly important when there is a "long and tortuous path to market”. A number of respondents commented on problems encountered with licensees sitting on licensed technology and not being willing to put money in to further develop it, hoping to on-license without any further development.

\section{Fee quantum}

One research institution respondent commented that their upfront fees tend to be in the $10 \mathrm{~s}$ of thousands rather than the $100 \mathrm{~s}$, although another commented that upfronts of around AU\$100,000 are possible. A patent attorney said that in his view AU\$100,000 is probably the norm with some milestones and around three percent royalties. However, it was well recognised that royalties tend to be a long time 
in coming, particularly for drugs, a decade or more. One respondent commented that if an exclusive licence is being granted and the technology is "out the door" they would want upfronts of hundreds of thousands. But for things like monoclonal antibodies, where products get to market fairly quickly, there would be more focus on the royalty component. Drugs, on the other hand, are a "black hole". The royalty component is likely to be as small as one percent for targets. For enabling technology, it is more likely that a single access fee will be required, with no continuing obligation to pay royalties.

Royalty percentages are hugely variable. Research institutions can generally expect a very low royalty rate, depending on their technology and the number of steps from product development. From our interviews, we have formed the impression that an average figure is probably around one to two percent. One respondent reported a deal with a large pharmaceutical company where the patent holder was happy with a three percent royalty rate. When research is further downstream it may be possible to get a much higher royalty rate. However, one patent attorney noted that a high royalty rate may be an indication that the product will not make it to market. Ultimately, the rate depends very much on the nature of the technology. Royalty structures are also variable. They may start high and decrease over time, or start low and increase. Where product sales become good royalty rates may decrease. Or royalties may be flat.

A trade association representative said that:

If your product is a niche product it does not matter how much you ask. A commodity product would probably get three to five percent. Around 0.5-3 percent starts to hurt. In between three to seven percent is not unreasonable. A complex area would probably demand around seven to 12 percent, a borderline product 12-15 percent - a licensee can substantiate the price at the other end. Above 15 percent you need a huge margin. But it depends how much it will cost to manufacture, how much you have invested and how much you can sell the product for.

High royalty rates can be agreed to in some circumstances. For example the OECD Report states that royalties can be up to 10 percent for "must-have" technologies and that they can sometimes 
reach as high as 20 percent. $^{209}$ Some of our respondents reported that small molecule patents tend to be very lucrative and are likely to be licensed exclusively with high royalties. Broad technology may also be lucrative, but this is more likely to result from many small payments for non exclusive licences. For drug companies, one of the particularly difficult areas is formulation patents. It appears that formulation companies tend to ask high royalties, as much as five percent and want a fee for service as well.

\section{Negotiation failures}

Negotiations can fall through for a whole range of reasons, including disputes about ownership, onerous terms and breakdowns in relationships (which is perhaps the greatest cause). Although price is a major negotiation issue, a licensing consultant suggested that it not as likely to be a cause of negotiation breakdown. However, an upstream company respondent said that price is a sticking point, particularly the need to get return for investment in research costs, licence costs, ongoing patent costs etc. As previously noted, the focus for the party seeking to license-in is future value which is harder to evaluate and may be quite different from costs incurred. One respondent said that licensing negotiations never run smoothly but get bogged down in detail. However, a trade association representative put difficulties in negotiation solely at the door of the negotiator:

Wherever a licence has proved problematic you should look at the skills of the negotiator. Generally you will find bad development, bad negotiator, and egos. In my view deals are not problematic.

\section{SUMMARY}

This chapter demonstrates the difficulties encountered by Australian industry participants in transferring their technology downstream to enable product development. Clearly, biotechnology is a high-risk business. There are major challenges both for research institutions and companies wanting to move their technology or products out, and for companies seeking to add value by further developing technology.

\footnotetext{
${ }^{209}$ OECD, above n39 at 61.
} 
We have already seen that the Australian research sector is a rich source of innovation. However, benefit to the public will only be realised if product development is facilitated. As would probably be expected, the usual business strategy of an organisation is to exclude competitors from the immediate area of interest and from as broad a penumbra around the area of interest as possible. This is the general rule irrespective of whether the area is of immediate interest or is a component of the future strategic plans for the organisation or even when it is only of peripheral interest and may be abandoned in the future. This raises a number of important public interest issues that will be discussed more fully later this report. It is particularly important to highlight the delicate balances involved in determining both the extent of the penumbra that should be allowed around areas of interest and the extent to which it is permissible to shield areas of interest when there is no immediate or long term intention to exploit them.

Most of the participants in our study indicated that there is extensive collaborative activity across all of the industry sectors. Collaborative activity is seen within and between research institutions, small and medium companies, large companies, government agencies, cooperative research centres, and so on, both within Australia and internationally. In many cases one of the reasons for such activity is to enable access to existing or new intellectual property. These types of arrangements are likely to facilitate technology transfer provided that appropriate provision is made for dealing with intellectual property ownership and licensing at the outset. Absent these collaborative arrangements, it seems that it is very difficult to for research institutions and companies to find suitable technology transfer partners and negotiate agreements that are mutually beneficial. In the past, the licence deals entered into by Australian institutions and companies may not have fully reflected the value of the technology. Negotiating strategies are improving, but, as we have already noted, we got the impression from our respondents that there is still a "buyer's market" 


\section{RESULTS CHAPTER 3: IMPACT OF PATENTS ON THE RESEARCH SECTOR}

In this chapter we report on a number of specific issues faced by the research sector in its internal dealings with intellectual property. We focus on the strategies employed by research institutions in managing their patents, with particular reference to:

- changing attitudes towards commercialisation;

- the impact of patents on publication;

- quantum and quality of patent applications;

- ownership and clean title; and

- valuation of intellectual property.

It appears to be generally recognised that research institutions, which were traditionally poor at managing their intellectual property, have improved greatly over the last decade or so. Some of the larger institutions have their own technology transfer office, staffed by people with expertise in patent prosecution, deal negotiation and science. In some instances these offices have been spun off into technology transfer companies. Other institutions may have a single technology transfer officer or business manager. Some still have no one at all, or have part time assistants with a low level of expertise. A number of institutions have arrangements with companies set up specifically for the purpose to advise on patent prosecution, commercialisation and technology transfer.

It was widely recognised by respondents that one of the important features of good intellectual property management is good dialogue between researchers and technology transfer officers. In a number of institutions it is an essential requirement to report all potential intellectual property to the technology transfer arm of the institution. One important issue that was emphasised by some respondents is the need to keep good laboratory note books - particularly if patents are lodged in the United States because of the first to invent rule. 


\section{CHANGING ATTITUDES TOWARDS COMMERCIALISATION OF BIOTECHNOLOGY RESEARCH}

There are still some research institutions for whom commercialisation is not a core activity. This situation exists where the institution is still able to get the bulk of their funding from the public sector. However, the number of such institutions is ever decreasing. For most, commercialisation is a reality, albeit an unwelcome one for some. For example, one respondent said that researchers hate patents, and see patenting as prostitution, but they pay the bills. Another said that some researchers just don't want to know about patents and others make jibes about the patent system. He described attempts to change attitudes about patents in the research sector as "trying to turn around a big ship”.

Many respondents acknowledged that patenting is having an effect on traditional scientific practices. For example one upstream company respondent commented that patenting has closed down the free exchange of science between researchers. However, it was generally recognised by respondents that research institution researchers are getting much better playing the commercialisation game, including identifying patentable inventions and protecting secrecy. One respondent stated that:

Those that are very good at research may be more willing to take their intellectual property to market. There are two motivations. The main one is whether it is the core activity of their employer. The other is the willingness to look outside the square. The best scientists are willing to commercialise. For those that are not willing this is because commercialisation is not the core activity of their institution or that commercialisation is seen as a dirty word.

And a technology transfer officer noted that:

There are two types of researchers: those that always have their eye on further activities. For them, intellectual property is the currency. They know that it is an important part of their work. Others (generally 
older academics) find it really annoying. They find it difficult to understand corporate bodies, ownership of intellectual property and employment issues. But this culture is changing. We rarely come across problems now.

These positive views about commercialisation are mirrored in other studies. For example, Anne Monotti and Sam Ricketson reported the results of a survey of academics from Monash University in 1997. The survey revealed that 68 percent of respondents agreed or strongly agreed that academic staff should explore the commercial potential of their research and teaching materials. ${ }^{210}$

On the other hand, a number of respondents commented on the equally important goal of ensuring that academic researchers retain the independence to pursue their own independent research even though this may be at the cost of lost commercialisation opportunities.

Respondents acknowledged that one of the main reasons for the change in research culture to research with commercial potential is because of funding preferences of such organisations as the ARC and NHMRC for this type of research. Other reasons include the need to obtain funding from the private sector because of shortfalls in public sector funding, the desire for economic viability, and perhaps for some a perception that a fortune can be made for "blockbuster" inventions. For example, one respondent said that patents are seen as being sexy. Researchers are aware of others making large amounts of money out of commercialising their intellectual property and have become jealous of their own intellectual property.

However, there are particular issues for research institutions that need to be addressed. In part these arise from the differences in research culture between the research sector and the private sector and lack of expertise in the process of commercialisation in the research sector.

\section{PATENTS AND PUBLICATION}

One of the biggest challenges for researchers based in research institutions is to balance the need to publish their research results in high quality peer reviewed journals against the need for secrecy and

\footnotetext{
${ }^{210}$ Monotti and Ricketson above n197 at para 9.17.
} 
limited disclosure to protect the patentability of inventions. Because non-disclosure is such an important issue in terms of patent validity, and because disclosure of research results is a key performance measure in the research sector, it is recognised as being essential for those research sector organisations for whom commercialisation is a core activity to have strategies in place to manage publication of patentable inventions. Respondents indicated that researchers generally are conscious that the key issue when protecting intellectual property is not to publish. One university technology transfer officer said that in her view the organisation had not lost any intellectual property through publication to date. She noted that the university has a package telling scientists how to keep track of their intellectual property. Another said that patents and publications can be complementary if managed properly and that publications can be used strategically by scientists to get their names into the public domain. Thus it would seem that the requirement to maintain secrecy is not necessarily a problem provided that this does not unduly delay publication of research results. As Monotti and Ricketson put it: "it is not secrecy per se that is the problem, but the length of the delay.",211

Participants in the research institutions survey and in the diagnostics survey were asked to comment on the impact of patenting requirements on their ability to publish their research results. Responses were varied. They are summarised in Table 13.

Table 13: Views on the impact of patents on publication in the research institutions and diagnostics sectors

\begin{tabular}{|l|c|c|c|c|c|c|}
\hline & Pos (\%) & Neg (\%) & $\begin{array}{c}\text { Nil } \\
(\mathbf{\%})\end{array}$ & $\begin{array}{c}\text { Neg/nil } \\
\mathbf{( \% )}\end{array}$ & $\begin{array}{c}\text { Pos/neg } \\
(\mathbf{\%})\end{array}$ & $\begin{array}{c}\text { No answer } \\
(\%)\end{array}$ \\
\hline $\begin{array}{l}\text { Research } \\
\text { institutions }\end{array}$ & $2(9)$ & $4(18)$ & $7(32)$ & $4(18)$ & $2(9)$ & $3(14)$ \\
\hline $\begin{array}{l}\text { Diagnostic } \\
\text { facilities }\end{array}$ & $2(15)$ & $6(46)$ & $3(23)$ & $1(8)$ & 0 & $1(8)$ \\
\hline
\end{tabular}

\section{Specific comments from research institution respondents}

A number of research institution respondents provided comments to justify their views on the impact of patents on publication. Most of those respondents who expressed negative views based them on delays in publication. For example, one respondent noted that delays

\footnotetext{
${ }^{211}$ Monotti and Ricketson above n197 at para 11.49 .

${ }^{212}$ Percentages are based on the 13 survey respondents involved in research.
} 
are such that "by the time publication is allowed data from around four to six papers is usually condensed to one (or not published at all)." Others also referred to the general negative impact on the dissemination of information.

Other respondents viewed patents as having more of a neutral effect, on the basis that once a provisional application is filed, publication can proceed without any significant delays. In such cases, it would seem that the slight delay in publication while the provisional is prepared and filed is not a major issue. However, some respondents added the rider that the process must be properly managed because otherwise there may be delays in publication of 12 months or so. One person noted that the impact depends on the agreement with the funder and that publication "is only one problem out of many so far."

A few respondents viewed the impact much more positively on the basis that it focuses on better outcomes and management processes and encourages early publication post-patenting. For some, the impact could be both positive, by focusing the researchers in getting all of the necessary information together, and negative, because of the stress involved in filing prior to publication.

The comments of one respondent appeared to focus more on the negative impact of publication on patents on the basis that

Many provisional patent applications are hurriedly put together because of pending disclosures. Scientists do not inform intellectual property managers prior to submission, because the delay in patenting allows scientists' competitors to publish first.

\section{Specific comments from diagnostic facility respondents}

A number of respondents to the diagnostics survey provided quite detailed responses to questions about the impact of patents on the delivery of genetic tests to end users. These results are presented later in the section that specifically addresses end user issues. Only a few respondents provided comments to questions on the impact of patents on publication. Of those who did respond, a number expressed similar views to many research institution respondents, that the requirement for researchers to patent their inventions had no impact on their ability to publish their research results, particularly if managed properly. One respondent commented: 
There is no impact, from extensive personal experience. Once protected by patent (at draft manuscript stage) we proceed with submission of manuscript to journals for publication.

However, other respondents expressed entirely contrary views - that patents have a negative effect because of the delays they cause in publication and knowledge dissemination. For example, one said that patents "can delay publication for years and reduce the ability to obtain a PhD." And another commented on the problem of balancing "the need to patent prior to disclosure versus the need to publish or perish mentality of the research funding system.”

\section{Interview data}

Most research institutions have a requirement that all publications have to be vetted and signed off either by the head of the research group or a technology transfer officer. Some have arrangements with industry that require that the industry partner inspects and approves all publications. These arrangements inevitably slows the publication process. However, the length of delay is extremely variable. If the only requirement is that the group leader checks the publication then the delay may be as short as 24 hours. Where an industry partner is involved the delay may be up to three months, although provisions of this nature seem to be far less common now than, say, five years ago. One respondent said that generally in their contracts there is a clause allowing an arbitrary 30-day period for review, but ordinarily turn around is likely to be much more rapid. One technology transfer company respondent said that they aim for a two-week turn around but realistically they usually look at six weeks. Another said that CRCs have a "30-day deal" for vetting publications. A research institution respondent said that the maximum delay is two to three weeks and that this is not a big turn around. Conversely, another said that they experienced a three-month turn around, which is meaningful in science.

Even if there are no contractual limitations on publication, care still has to be taken in making the decision whether to publish or not. One technology transfer officer said that if publication occurs before the patent has been granted in the United States then large pharmaceutical companies in particular would not be interested. This comment was backed up by a research institution researcher who said that you don't 
really want to write anything until two to three years after the patent has been filed to make the patent as strong as possible.

Granting agencies are increasingly recognising intellectual property ownership as a measure of academic excellence. However, this is not necessarily the case for the research institutions themselves. One university technology transfer officer said that because of the impact of intellectual property on publication academic promotions policy needed to be amended to reflect this. On the other hand, another respondent noted that some academic institutions do realise that scientists coming back from industry will lack a strong publication record and this will not be taken against them. This same respondent pointed out that it would be naïve to go to a company thinking that you could continue to publish.

\section{Impact of publication on patenting}

The above discussion focuses on the impact of patents on publication. Some respondents commented on this issue from the other perspective, namely the impact of publication on patents. This issue arises because the need for scientists to publish was widely recognised. One company respondent said that his company recognises and respects the right to publish. In his particular case he noted that because the company's own scientists and collaborating research institution scientists are aware of the issues associated with publication and patenting, no problems have been encountered. However, one of the problems that some respondents identified is that sometimes it would be better to keep information proprietary as secret know-how, but because of the publishing ethos it is necessary to file provisional patent applications instead. Company respondents noted that is not always beneficial to put too much information into the public domain, particularly when research is really in the precommercial phase. However, the pressure of publication may force companies to do so. Some further implications of this pressure to patent at the preliminary research stage are discussed in the next section below.

\section{QUANTUM AND QUALITY ISSUES}

Following an early reluctance to patent, it appears that some scientists have become over-enthusiastic in their adoption of a pro-patenting stance, to such an extent that patents are taken out when there is little 
or no likelihood of commercial exploitation. One respondent noted that the pressure to generate income is causing lots of patents to be filed but that licensing income from them is generally low, about two percent return for investment (although a couple of universities have hit the big time). This data is supported by other studies. Monotti and Ricketson, for example, comment that there has been an increase in the propensity to patent but that even in the United States this hasn't been matched by increased output, with the bulk of technology transfer revenue coming from a few successful inventions, the "big hits" or "blockbusters". 213

One problem with the quality of patent applications is that often provisional applications will be rushed through to allow research results to be published or presented at a conference. An intellectual property advisor noted that:

Generally there will be no intellectual property strategy and the patent will have been filed at the last minute. The patent attorney will not have been given adequate advice about strategy. Fair basing will be a problem - it may be necessary to re-file unless claims are broad enough.

A number of respondents reported that organisations are finding solutions to these problems by becoming much more proactive about intellectual property management and education. As one respondent noted, the focus is on looking for and developing genuine commercial opportunities, looking for commercial partners early in the process and drafting good provisional patent applications. The biggest issue continues to be financial. Research institutions have to find commercial partners within a very short time frame because they often do not have sufficient financial resources to take patents beyond the provisional phase. One respondent reported that because they have to find a partner before the complete application needs to be filed, this means that they may have to settle for a couple of percentage points less on royalties.

For the most part, research institution respondents stated that they look for a commercial partner after the provisional is filed. One respondent explained that the reason for this is that patents are important commercial bargaining tools. In addition, in their view if it

\footnotetext{
${ }^{213}$ Monotti and Rickeston, above n197 at paras 9.51-6.53.
} 
is too early to patent it is also too early to be talking to potential partners. Others are less averse to finding partners prior to filing the provisional.

\section{OWNERSHIP AND CLEAN TITLE}

Perhaps the most important aspect of any intellectual property management strategy is ensuring that there is no uncertainty about ownership of the intellectual property. It is generally recognised that where intellectual property is created by an employee during the normal course of their employment then ownership vests in the employer, absent any agreement to the contrary. However, in the research institution setting the issue is complicated by a number of factors including, but not limited to, the following:

- uncertainty as to the "normal course of employment";

- involvement of students and visiting scholars in particular research projects generating intellectual property;

- funding arrangements;

- collaborative arrangements; and

- background intellectual property and know-how brought to particular projects by individual researchers.

A recent Report commissioned by the Commonwealth Department of Education, Science and Training (the DEST Report) provided a detailed analysis of the complex legal issues associated with patent ownership in public research institutions. ${ }^{214}$ There is no Australian equivalent to the United States Bayh-Dole Act 1980, which enables research institutions to claim ownership of intellectual property created using government funding in certain circumstances. To a limited extent, equivalency is achieved through:

- common law rules regarding ownership of intellectual property created during the course of employment (normally vesting in the employer); together with

\footnotetext{
${ }^{214}$ A. Christie, S. D’Aloisio, K. Gaita, M. Howlett and E. Webster Analysis of the Legal Framework for Patent Ownership in Publicly Funded Research Institutions (Canberra: Commonwealth of Australia; 2003) (hereafter DEST Report).
} 
- the National Principles of Intellectual Property Management for Publicly Funded Research ${ }^{215}$ whereby funding agencies do not assert ownership rights over intellectual property arising out of projects that they fund.

The DEST Report recommended that the Australian position should be further clarified in order to remove impediments to effective management and commercialisation of intellectual property in the public research sector. Its recommended position was that ownership vest in the research institution by default. ${ }^{216}$ Our research indicates that most research institutions are already moving towards this position, with the notable exception of Melbourne University. ${ }^{217}$ A number of respondents commented on the unusual arrangement at Melbourne University, where ownership is in the inventor. However, the patent holder still has to obtain permission from the university for assignment.

Commercial partners will be disinclined to invest in development of technology if there is any uncertainty about ownership of the intellectual property that is tied to the technology. However, some respondents suggested that if the project is good enough, there may be a willingness to work through difficult ownership issues. Nevertheless, if the issues are too difficult partners will simply walk away. One respondent reported an instance where a project was abandoned as a result of messy ownership, despite the fact that AU\$4 million had been invested and that there had been over two years of work done on the project. Conversely, if a project is likely to bring in many millions of dollars, payment of a small amount to clean up ownership is worthwhile.

As with most other aspects of intellectual property management, it appears that research institutions are getting much better at dealing

215 Australian Research Council; Australian Tertiary Institutions Commercial Companies Association; Australian Vice-Chancellors' Committee; Department of Education, Training and Youth Affairs; Department of Industry, Science and Resources; IP Australia; and National Health and Medical Research Council, National Principles of Intellectual Property Management for Publicly Funded Research (Canberra: Commonwealth of Australia; 2001). Available at: http://www.arc.gov.au/pdf/01_01.pdf (accessed 1 May 2003).

${ }^{216}$ DEST Report, above n213 at n212

${ }^{217}$ We refer specifically to Melbourne University because a number of our respondents drew our attention to the University's unique arrangements regarding ownership. We note further that the DEST report, above n212 also makes specific reference to the ownership arrangements at Melbourne University. 
with ownership issues. Most research institutions now have intellectual property policies in place which have provisions regarding ownership. Nevertheless, one respondent cautioned that people still don't cross the t's and dot the i's.

One licensing consultant emphasised the importance of having assignment deeds in place and ensuring that all researchers are content with the arrangements. This would certainly appear to be a welcome change in strategy. One respondent commented that she had been involved in one research project in which essentially all of her day to day work was licensed off to the commercial partner without her knowledge. She acknowledged that there is much more transparency now, with researchers being included in negotiating commercialisation agreements. Generally, research institutions have arrangements whereby inventors get a share in the profits of the commercialisation of their inventions. The general rule is that 30 percent goes to the inventor, 30-40 percent to their research lab or department and 30-40 percent to the institution.

In general, it appears that research institutions now routinely have provisions in place requiring assignment of ownership by employee researchers as well as students and visiting researchers.

\section{UNDER- AND OVER-VALUING}

One of the most difficult issues in any technology transfer arrangement is settling on the value of the technology. It was generally recognised by respondents that in the past Australian research institution researchers tended to under value their intellectual property, giving it away too soon for too little. One technology transfer officer gave an example of an assignment of intellectual property rights in return for a research assistant's salary for three years. However, a number of respondents reported that attitudes may now have swung too far the other way, with some researchers overvaluing their intellectual property. As one respondent reported:

Some people clearly over value. Because it has taken 10 years and several million dollars to develop their intellectual property they want around AU\$5 million upfronts. This is ridiculous when all they have is a provisional that has never been tested and the patent is not granted yet. In the past academic intellectual 
property got sold off very cheaply. There is a mixture between these extremes now. People don't want to be caught selling it off too cheaply. But if they get reasonable advice from a technology transfer company this should bring them back to reality.

Part of the problem is in making the distinction between research outcomes and commercial products. As one upstream company respondent put it:

It is a fair statement to say that universities and research institutions overvalue their intellectual property. When dealing with one public sector body there was an instance where we walked away. They insist on having a book value rather than market value on their intellectual property, which is ridiculous. We don't care what they have spent on it, the question is what it's worth to us. They try to salami when they should get an exclusive and vice versa.

Another company respondent noted that:

A number of institutions have an unrealistic idea of what their IP is worth. The up-fronts usually kill you...Licence agreements contain very limited structures and often it is just not worth it.

On the other hand, a technology transfer officer reported that even though scientists do want more for their money now, in the past they wanted far too little. Hence, the amount they are seeking now is probably a far more realistic estimate of the true value of their contributions and it is fair for them to get a reasonable return on their intellectual property. Nevertheless, this respondent described research and development companies as being "outraged" by the amounts being requested by research institutions for their technology. One upstream company respondent stated that it is the continuing royalty stream that is a problem and that they prefer upfront payments. In the end, what universities get will be determined by what the market will bear.

Some respondents reported that it is not necessarily the researchers themselves who have unrealistic expectations about the value of their 
intellectual property, but their host institutions: technology transfer officers lacking experience, universities expecting too much return.

It should be noted that research institutions are not alone in not fully understanding how to value their research and intellectual property. One company respondent commented that Australian companies also tend to licence too early with a promise of royalty payments 10 years down the track. Another commented that Australian companies and institutes tend to cave in when negotiations get bogged down and fail to fully appreciate the value of what they are acquiring and giving.

\section{SUMMARY}

In summary, we find that there is much to be optimistic about in terms of intellectual property management in Australian research institutions, at least amongst our respondents. Researchers are becoming more positive about the commercialisation and patenting process. Ownership issues are being resolved early in the process and the tension between the need for secrecy during the patent filing process and the need for rapid publication of research results is being managed. Nevertheless, there are huge challenges involved in the technology transfer process from the research sector to the industry sector. Major obstacles include finding partners, valuing the technology and acquiring appropriate negotiating skills. The process could be made far more efficient by education and consolidation of resources and knowledge bases both at the local and at the national level. 


\section{RESULTS CHAPTER 4: RESTRICTIONS ON ACCESS TO UPSTREAM PATENTS}

As explained in Context Chapter 3, it is important when considering foundational patents to consider the impact of restricting access to a particular patented invention. Technologies necessary for biomedical research fall into a number of different categories, and whether we should be concerned about access to technology being restricted will depend on the nature of the patented technology in question, and whether the person seeking access is in a competitive relationship with the patent holder. These categories are as follows:

- technology is being used by the patent holder and another researcher to conduct similar research, and the other researcher subsequently finds the technology is already patented (for example, where a lead compound being used for development of the same drug by competing researchers is covered by patent);

- the patented technology is useful for a range of follow-on uses, the products of which will ultimately compete (for example where a lead compound is being used for research into two different drugs that may ultimately compete with one another); and

- the patented technology is useful for a range of noncompeting, follow-on uses (PCR is a prime example).

The instances of restricted access with which we are primarily concerned fall into categories two and three. It is in these instances that there may be significant social cost associated with restricting access. Society would want, for example, patented inventions that fit into category three to be widely disseminated. In this way, broad innovation will be promoted and society will benefit through the introduction of a variety of new products. On the other hand, society accepts that there will be some reduction in competition associated with the patent system, and is accordingly less concerned with restricted access to patented inventions that fall into category one. Although there may be a cost disadvantage where competing researchers are precluded from developing competing products, there is unlikely to be a reduction in products available to consumers. 
The second category is more problematic, and the desirability of promoting access becomes more equivocal. Broad access is desirable because the potential of the invention is more likely to be maximised through having a variety of innovators exploiting the invention. Walsh, Arora and Cohen cite the examples of Geron's exclusive licence for human embryonic stem cell technology and Myriad's diagnostic test licensing as having a dampening effect on research. ${ }^{218}$ In most cases, the scope of the patent claims will clearly become an important issue, because this will determine the breadth of follow-on research affected by the patent.

Although it is not always clear which category a particular patented invention is likely to fit into, we have attempted to bear this distinction in mind when considering whether our data gives us any insight into issues associated with restricted access to patents. This chapter presents evidence relevant to whether or not participants in the Australian biotechnology industry are having difficulties accessing patented upstream products or technologies that are required to enable them to conduct research.

In the United States, the preconditions for restricted access to foundational patents certainly appear to exist, because a number of important, broad-ranging research tools are patented. ${ }^{219}$ In some cases, these research tools can be used for a range of follow-on research activities. Furthermore, some patent holders are vigorously enforcing their patent rights in the United States.

As a result of this, concern has arisen that access to crucial patents will be blocked, and an array of follow-on research activities will be precluded at the expense of innovation. This concern may be lessened to some degree in Australia given that our research has revealed that a number of these fundamental patents have not been patented in Australia. It seems fair to assume that this may be the case in respect of a number of other patents over research tools.

These research tools can therefore be used for research and development in Australia without fear of liability for infringement. Whether any commercial products of research using these research tools can be exported into markets where they are patented depends

\footnotetext{
${ }^{218}$ Walsh, Arora and Cohen, above n28 at 333. See also above Context Chapter 3.

${ }^{219}$ See Heller and Eisenberg, above n131; Walsh, Arora and Cohen, above n28. See also A. Rai 'Genome Patents: A Case Study in Patenting Research Tools' (2002) 77 Academic Medicine 1369. See also the discussion above in Context Chapter 3.
} 
on the jurisdiction in question. Governments in many of the major markets have prohibited such a practice. ${ }^{220}$ For example, in the United States, the importation of intellectual property protected products, produced offshore without the consent of the owner of the technology is not allowed. However, the recent court decisions in Bayer AG v Housey Pharmaceuticals ${ }^{221}$ cast some doubt of the ability of these provisions to protect patent holders where a drug is developed using a patented method. This litigation involved the Method of Screening patents discussed in Context Chapter 3, and had the following outcomes:

- the patents are restricted to research methods and do not include manufacturing methods;

- the provision in United States patent law prohibiting importation for the purpose of sale or use of a product made by a process patented in the United States only applies to patented manufacturing processes and not to research processes; and

- importation of products produced using those research methods in other jurisdictions does not infringe the patents.

This may, to some extent, place participants in the Australian industry at an advantage over participants in other jurisdictions. ${ }^{222}$ Despite the status of these foundational inventions, there is no doubt, however, that other important methods and technologies which will be required for biomedical research are patented in Australia. The patent landscape is becoming increasingly complicated, and many upstream inventions have now been patented. In addition, it may be that research being conducted by the Australian industry is likely to be seen as increasingly threatening as Australian companies and institutes gain an international presence. In addition, although it would appear that patent rights have not been enforced as vigorously as they have in other jurisdictions, this is something that seems certain to change. Both overseas and Australian companies are starting to take a more aggressive approach to enforcement. A good

\footnotetext{
${ }^{220}$ The essential issue here is the composition of provisions in national intellectual property legislation for parallel importation, which is the practice of importing products developed offshore (in a jurisdiction where the technology is not protected by patent) using the patented technology. While some jurisdictions allow parallel importation, most developed countries prohibit the practice.

${ }^{221}$ Housey cases, above n108.

${ }^{222}$ See Context Chapter 3.
} 
example of this is the stance taken by GTG in relation to their junk DNA patents. ${ }^{223}$

The issue of restricted access to patents is therefore an important issue for the Australian industry. Even though a considerable amount of upstream research is conducted by the Australian industry, respondents in all of the sectors we investigated, frequently require access to upstream patents. Even upstream researchers may need to access patents over particular research tools that are crucial to their research, as not every upstream researcher is in the position of having developed and patented every research tool they may need to conduct their research.

In their study of the United States industry, Walsh, Arora and Cohen were cautiously optimistic about limitations on access. They warned that although research in broad therapeutic areas has not been blocked to date, this may be through a combination of luck and institutional response, and the potential to impede progress in a broad research area still exists. $^{224}$ To some extent, the same potential exists for the Australian industry.

In investigating this issue we consider evidence relevant to:

- the existence of blocking patents in the industry;

- whether licences are being refused;

- the effect of exclusive licensing;

- costs and delays associated with successful negotiations for access to patents;

- the effects of particular terms in licensing agreements; and

- failure to exploit patents.

\section{BLOCKING PATENTS}

\section{What do we mean by “blocking patents"?}

In the company survey, we asked respondents whether their company had ever had to change its research program because a patent blocked access to key research tools or materials. Nine respondents reported that they had changed their research program, (18 percent) and as

\footnotetext{
${ }^{223}$ See Context Chapter 2.

${ }^{224}$ Walsh, Arora and Cohen above n28 at 335. See also Straus, Holzapfel and Lindenmeir, above n35 at 9-11.
} 
would be expected, several of these respondents indicated that existing patents heavily influenced their research programs, with one other commenting that only slight changes in the scope of their research were required to avoid infringing patents. ${ }^{225}$ One indicated that they left the field completely if they were unable to work with patent holders to enable them to access necessary patents. Another four respondents provided comments that indicated they had come across patents that would potentially impact on their research programs. We did not go on to ask how the companies' research programs had changed, however this was an issue we explored in more detail in the interviews.

Of the 18 diagnostic institutions surveyed, only one reported access to patents necessary to conduct research being blocked (five percent). The patents in question were the BRCA1 and BRCA2 patents. Four of the 21 research institutions surveyed reported having to change their research program because a patent blocked access, and their responses were qualified. It may be that this figure was significant because they are less concerned about proceeding without a licence given that they rely on the existence of a research exemption.

We are careful here in using the term, "blocking patents", as the term has a specific legal meaning. Blocking patents occur where one patent holder holds a broad patent over an invention (the dominant patent) and another patent holder holds a narrower patent over an improvement to that invention, or a new invention (the subservient patent). ${ }^{226}$ The holder of the subservient patent requires a licence from the holder of the dominant patent, and the holder of the dominant patent would be precluded from exploiting the improvement without a licence. In most cases, once an improvement is developed and commercialised a licence from the holder of a pioneering patent that blocks the improver from practising the improvement, would be required. The blocking patents doctrine has a limited application, and the question referred to above was intended to include situations where research to develop improvements was stymied in that it was perceived that a licence to a foundational blocking patent might not be granted. It essentially sought to determine whether any respondents had taken steps to avoid a blocking patent situation.

\footnotetext{
${ }^{225}$ Note that two of these responses were received from non-biomedical companies. Both of these respondents described their activities as falling into the category of plant/animal research.

${ }^{226}$ See Merges and Nelson, above n138 at 860-861, and also at their note 96, which discusses the intuition behind the grant of blocking patents.
} 


\section{Evidence of blocking patents}

A significant number of interview respondents considered blocking patents to be a real issue within the industry. Many respondents commented that they could not see the value of companies obtaining patents purely for blocking or defensive purpose. Having said this, 21 respondents to the company survey had applied for a patent for strategic reasons, that is, to allow them freedom to operate (43 percent). In most cases, that patent had been granted. It was not clear whether those particular patents were subsequently exploited or licensed-out, however many respondents who participated in interviews either had patents that they did not currently exploit, or knew of companies who did not currently exploit. In many cases, these patents were not licensed or otherwise transferred, although this may have been due to a number of reasons. ${ }^{227}$ In a number of instances respondents subsequently let patents lapse they did not exploit, and routinely undertook audits of the patents on their books to enable them to identify these patents.

Although the occurrence of the blocking patents doctrine has traditionally been considered to be fairly limited, one patent attorney we interviewed had experienced many instances of blocking patents, as "[e]verything (in biotechnology) uses other people's patented technology." As this respondent put it, researchers need to either tiptoe around the prior art or seek a licence.

A significant number of respondents we interviewed reported avoiding research in an area because they were aware that another company held a patent to which they required access, and they considered they would have difficulty gaining access to that patent. In many cases, this was a clear competing products case as outlined in category one above, because these respondents indicated that they were in a horizontal relationship with the patent holder. In some cases, however, it was less clear that this was the case and it was more likely that the patented technology fell into category two.

Some respondents engaged in academic research reported having difficulties gaining access to necessary patents. It would appear that patent holders are becoming increasingly wary of infringement by

\footnotetext{
${ }^{227}$ For example, the patents may have had limited commercial value, or may not have been very marketable. The difficulties associated with licensing or otherwise transferring technology out were canvassed in Results Chapter 2.
} 
academic researchers as the line between academic research and commercialisation becomes increasingly blurred. Again, it appeared in a number of cases that the technology in question fell into category two, although our data does not allow us to form a strong view on this. This clearly poses a problem if a single patent has broad applicability, and restricting access has the potential to block off whole areas of research that cannot be foreseen at the present time. The question here as we pointed out earlier, is whether these patented inventions to which access was blocked, comprise foundational discoveries that are key to broad areas of subsequent research.

The result of these licensing practices is also, as one respondent pointed out, that the patent holder will lose ground by failing to allow anyone to work on their patents. There must be some social cost associated with this, as well as the strategic cost to the patent holder of falling behind.

\section{Overcoming blocking patents}

Of the interview respondents who commented that they had encountered difficulties of some kind with patents blocking research, many of them said they had overcome these difficulties by changing the direction of their research so as to avoid infringing the patent(s). In some cases, these patents were owned by competitors and the problematic patents were patents over technology that would compete with any technology derived from the research program if it continued (category one). In this situation, although it is to be expected that being granted access to a competing patent is unlikely, one research institution respondent said that a licence deal might even be attractive to a competitor if you have a skill set that they want.

Other respondents required licences to research inputs to enable them to proceed, and tended to avoid research areas (or subsequently change the direction of their research) unless they were relatively sure they could obtain a necessary licence. ${ }^{228}$ Successful licence agreements were often reached. In a considerable number of cases where a licence was required and the researcher approached the patent holder, respondents indicated that a successful licensing outcome was eventually negotiated. One licensing manager contended that 99.99 percent of licensing deals within the industry

\footnotetext{
${ }^{228}$ This becomes an anticommons issue where a number of patents block research and access to them proves to be problematic.
} 
run smoothly, and only about 0.01 percent stand out as anomalies. In his view, it is not correct to say that there is any blockage to research except in exceptional cases.

However, in many instances, respondents did not even try to negotiate a licence as they were of the view that the patent holders would be unlikely to enter into negotiations with them. In a majority of cases, these respondents fell into category one, although a number fell into category two.

Licensing was the main strategy by which access to patents could be negotiated. In the case of blocking patents, cross-licensing is a mechanism by which a blocking patents situation may be overcome. While only a small number of interview respondents had been involved in any cross-licensing activity, a significant number considered that cross-licences would become more common within the industry. ${ }^{229}$

Some respondents (particularly where the technology to which they required access fell into category one) reported that inventing around was a strategy they had employed to enable them freedom to operate, while others redirected their research efforts to avoid infringing relevant patents. Respondents from the pharmaceutical sector were generally of the view that it is not possible to obtain broad patents that block research in the pharmaceutical industry because of the ability of researchers to invent around. It was evident that these pharmaceutical patents represent a clear case of patents that fall into category one. The issue of inventing around will be canvassed in more detail in Results Chapter 7 while redirection of research in relation to anticommons issues will be discussed in Results Chapter 5.

Note also that the Australian Patents Act 1990 provides that a compulsory licence may be granted where an applicant seeks access to a patent and also a patent that blocks them from exploiting that patent. $^{230}$ The applicant will only be successful in obtaining a compulsory licence where the new invention involves an important technical advance of considerable economic importance on the other invention. ${ }^{231}$ Although the compulsory licensing provisions under the

\footnotetext{
${ }^{229}$ See also Results Chapter 7.

${ }^{230}$ See sections 133(2) and 133(3B)(a).

231 Patents Act 1990 (Cth) section 133(3B). For further details on when a compulsory licence may be granted, and the conditions on which a grant is predicated, see ALRC, above n18 at 234-36; Nicol and Nielsen above n4 at 370-71.
} 
Patents Act have been utilised only very rarely, the threat of an application for a compulsory licence probably provides an impetus to industry to enter into licensing negotiations and ultimately into contractual arrangements. $^{232}$

\section{REFUSALS TO LICENCE}

Of the companies that responded to the company survey, six reported being refused a patent licence (12 percent). Two other respondents did not indicate that they had encountered a refusal to license, although their answers to later questions implied that they had. ${ }^{233}$ The question was intended to elicit responses as to unilateral refusals to licence, although it would appear in one case at least that the refusal was predicated on unreasonable terms. Of the six companies who were refused a licence, none reported being in a vertical relationship with the patent holder, and three reported being in a horizontal relationship. ${ }^{234}$ We did not receive responses about the nature of the relationship between the parties from the other three.

Reasons for the refusal were given by three respondents: two reported that exclusive licences were granted to another party, and the other stated that they were in competition with the patent holder. ${ }^{235}$ It would be fair to say that a majority of these companies were significant in terms of size as measured by number of employees and revenue, with most of the respondents reporting revenue in excess of AU\$5 million. Three were internationally owned. All of the companies had a significant number of patents ranging from eight to "thousands". We also asked respondents about the kind of patent for

${ }^{232}$ IPCRC, above n47 at 162; F.M. Scherer 'Comments' in R. Anderson and N. Gallini, (eds) Competition Policy and Intellectual Property Rights in the Knowledge-Based Economy (Calgary: University of Calgary Press; 1998) 104-109 at 106; Nuffield, above $\mathrm{n} 40$ at 55 . See also the discussion on compulsory licensing in Part 3 of this report.

${ }^{233}$ Note that one of these respondents was engaged in plant/animal research rather than biomedical research, although the patent for which a licence was apparently refused was described as an active drug patent.

${ }^{234}$ The respondent referred to above at n219 also reported being in a horizontal relationship with the patent holder.

${ }^{235}$ One other respondent who did not provide an affirmative answer to the refusal to license question, cited unreasonable terms as a reason for a refusal to license - it is not clear whether there was a refusal or not, but it seems in any event that it was not a unilateral refusal to license. 
which a licence was refused. Four respondents provided this detail, ${ }^{236}$ with one answering research tool, two answering gene sequence, ${ }^{237}$ and one answering active drug patent. ${ }^{238}$ We surmise from the information concerning relationships with the patent holder or exclusive licensee, that a number of these patents fell into category one, however this is not altogether clear from the limited data available. Given the kinds of patents to which access was refused, it may be that in one or two instances the patented technology fell into category two.

Of the research institutions that responded to the survey, only two reported that they had been refused a licence (nine percent), and only one of those institutions had had to abandon a particular area of research because of the refusal. None of the diagnostic institutions surveyed had encountered a refusal to license, probably due primarily to the low level of research and licensing-in being undertaken within the diagnostics sector.

\section{The interview data}

This perception that unilateral refusals to license are not a pervasive issue within the industry was reinforced by the interview data. Most of the company and research institution respondents we spoke to had not encountered outright refusals to license, although one respondent whose companies were involved in downstream development activities offered the following:

The responses we have had in requesting licences have been a mixed bag. We have only negotiated with US companies. Many small to medium sized US companies have told us to go away, they would rather not risk losing a potential market. Larger companies have not been such a problem - they are willing to license and realise they will not enter this area. We have not been offered licences on restrictive terms, we have only had outright refusals to license.

\footnotetext{
${ }^{236}$ One other respondent who had not answered yes to the refusal to licence question, answered this question - enabling technology. They also said the patentee was in a horizontal relationship with them.

${ }^{237}$ One of these was also described as diagnostic.

${ }^{238}$ What we don't know is whether the patents were being exploited in any event by either the patentee or another licensee.
} 
This account appeared to be somewhat isolated. Another respondent engaged in downstream development activities reported that there had been an occasion where a research tool patent holder did not want to license them, but ultimately licensed their partner which solved their problem in any case. One university technology transfer officer stated that they had been refused licences but generally the problem was that terms were unacceptable.

One interpretation of this data is probably that refusals to license were not encountered because often it did not get to the stage that licences were requested. This was acknowledged by many of our respondents. As reported elsewhere, researchers and companies stated that they avoided particular areas of research if patents were held by competitors, or if it looked as though obtaining a licence might prove to be too problematic. In some cases technology clearly fell into category one, but in other cases it is likely that the patented invention fell into category two. For example, a respondent from a large pharmaceutical company stated that if it was clear the patent holder would not give a licence over a target, they tended not to pursue it. They had a large number of targets to choose from, so abandoning targets because they could not obtain the necessary licences to continue research was not hugely problematic. Another respondent from a large pharmaceutical company agreed that refusals to license do happen, but thought that deals that didn't work out were probably unsuccessful because of the low probability of success rather than other aspects.

To summarise, in line with the survey results a few interview respondents expressed frustration at difficulties in licensing-in enabling technologies, but these were greatly outnumbered by the number of respondents who had not experienced any problems. Some respondents complained that owners of research tool patents, while willing to license, unreasonably demanded reach-through royalties. ${ }^{239}$

Patented research tools were also frequently used without licences, particularly by universities where it was unlikely or unclear whether or not a commercial product would result. It was conceded by a number of respondents that it would be impossible to know what every lab or company was doing, so policing use of your research tool patent would be extremely difficult. A patent attorney we interviewed

\footnotetext{
${ }^{239}$ See discussion dealing with reach-through rights in Terms, below, and Results Chapter 5.
} 
agreed that research tool patents are very difficult to enforce, particularly at present when many research tool patents are owned by multinational companies.

\section{The basis of refusals to license}

Similarly, most respondents engaged in licensing-out their technology (including research tools) appeared to hold the view that it made good business sense to engage in fairly liberal licensing practices. This is not to say that exclusive licensing practices, or licensing-out on terms that may be problematic to one party, are not common within the industry. It seems clear, however, that there are some parties with whom a patent holder would not contemplate a licence arrangement. Many respondents intimated this, and one respondent was more specific. Engaged in upstream research and development activities, this respondent gave three reasons why a requested licence might be refused. These were first, where the licence grant would conflict with their own business development, or with a licence granted to another party, particularly an exclusive licence. Second, a licence would be refused where the potential licensee was problematic in terms of finances or reputation within the market place. Finally, a licence would be refused where the intended application of the patented technology was unethical.

The first ground was undoubtedly the most common ground on which a licence would be refused, and this is in line with the survey results. It is to be expected that when a patent holder has a product patent, they are likely to refuse to license their own competitors or license two parties in competition. As stated by this respondent, "You have to be very careful not to licence to two competitors.” Again, we reiterate that patented inventions falling into category one are unlikely to be widely disseminated, and this is unlikely to entail significant social cost. Consistent with the objectives of the patent system, some degree of exclusion is to be expected.

In contrast, in situations where the products developed constitute broadly applicable foundational discoveries, failing to license broadly may have some consequent effect on downstream research. This respondent also pointed out that in circumstances where “...we may have given a licence for gene therapy to treat breast cancer, and someone else wants it for all cancers”, a licence would also likely be refused. Although there could clearly be a conflict for an exclusive licensee in such a case, it would certainly be questionable whether a 
company engaged in researching gene therapy for breast cancer competed with a company engaged in researching gene therapy for all cancers. This is more likely to be an instance that fits into category two, and that is more problematic in terms of restricted access. It is difficult to say with any precision how frequently such a scenario might arise.

A consideration then, that has major bearing on whether patent holders are willing to license others, is the technology in question. Whether the technology is core to the activities of the patent holder will be an important variable. Patent holders will be understandably reluctant to license inventions that fall into category one, and in some instances category two. However, it became evident to us while conducting interviews that patent holders are more likely to license non-core technologies. This may mean that patent holders are willing to license technology falling into categories one and two. Where they were not licensed, in many cases it would appear that the inventions were being exploited in any event, although we did receive reports of inventions not being exploited. ${ }^{240}$

Broadly applicable research tools (falling into category three) are more likely to be widely licensed because this is a method of maximising revenue on them. Permitting others to use some enabling technologies is unlikely to impact significantly on the competitive advantage a patent holder or licensee may have. We can conclude that our respondents reported no instances of licences to technology falling into category three being refused.

A similar conclusion was reached by Walsh, Arora and Cohen after conducting their interviews; ${ }^{241}$ in particular their respondents complained of restrictions on the use of targets. ${ }^{242}$ In considering a number of examples, however, their conclusion was that it was only in a number of limited instances that access to a target was completely restricted or limited, and in most cases the target was being exploited by at least one party. It should be remembered, however, that there may be some social cost or impact on innovation, when few parties are working on solving one problem. ${ }^{243}$ This is most

\footnotetext{
240 See discussion on Failure to Exploit Patents below.

241 And see also Straus, Holzapfel and Lindenmeir above n35 at 7.

${ }^{242}$ Walsh, Arora and Cohen above n28 at 310-14.

243 See Merges and Nelson, above n138 who argue that innovation will be best served by a variety of innovators working on improvements, rather than relying on
} 
likely to be an issue in respect of technology falling into categories two and three, with the former being the most problematic in practice.

\section{EXCLUSIVITY}

\section{The effect of exclusivity on research}

In considering the issue of exclusivity, it should again be emphasised that exclusivity is the cornerstone of the patent system. Exclusivity is part of the patent bargain, and the price society pays for the disclosure of invention. Without monopoly rights, the patent system would cease to function. The aim of this discussion, therefore, is to consider whether there are instances in which exclusive licensing practices are likely to hinder innovation in that use of an invention will be restricted. Again, the category into which technology will fall will be important, in that ideally non-exclusive licensing of inventions falling into category three (and probably two) will take place.

Our research has revealed that while many patent holders initially aim to disseminate their technology widely, licensing decisions are often driven by revenue considerations. Our data indicated that a majority of our respondents were involved in licensing-out technologies falling into categories one and two. Our respondents frequently expressed a desire to non-exclusively license these technologies where a number of licensees had been identified. But in many cases in order to extract the best bargain they were required to license on an exclusive basis. Pharmaceutical companies in particular, demand exclusivity, particularly in relation to drug targets. Where licensing decisions are dictated to some extent by the bargaining power of the respective parties, licences may be granted to fewer licensees than would be considered to be socially optimal. This is particularly the case where a category two invention may not be licensed to its full capacity, and other competing uses of an invention may be precluded.

\section{Exclusive licensing in practice}

Exclusivity can take a number of forms including geographical exclusivity, exclusivity for a limited period, or field-specific exclusivity. Licensing on an exclusive basis is commonplace within

the patent holder to coordinate development of subsequent innovation through licensing. 
the industry. Of the 22 respondents to the company survey who had requested licences, 16 of those respondents had entered into licences on an exclusive basis (73 percent of respondents who had licensed-in, 33 percent of total respondents). ${ }^{244}$ Ten parties had licensed-in on a non-exclusive basis, and five reported having both kinds of agreements. Two parties failed to provide details of the kind of arrangements entered into.

Sixteen of the 22 respondents who had licensed-out patents provided details of the kinds of licensing-out agreements they had entered into. ${ }^{245}$ Twelve respondents had entered into exclusive licensing-out arrangements (54 percent of respondents who had licensed-out, 24 percent of total respondents). Only six respondents had entered into non-exclusive arrangements, and four reported both exclusive and non-exclusive deals.

Eight of the 12 research institution survey respondents who had requested licences had entered into non-exclusive licensing arrangements (67 percent of respondents who had licensed-in, 35 percent of total respondents), and three had entered into exclusive arrangements (25 percent of respondents who had licensed-in, 13 percent of total respondents). Thirteen research institutions had licensing-out arrangements, and 11 of these provided details of the type of arrangement. Seven said they had entered into exclusive arrangements, (54 percent of respondents with licensing-out arrangements, 33 percent of total respondents) and four said they had entered into both exclusive and non-exclusive arrangements (36 percent of respondents with licensing-out arrangements, 19 percent of total respondents). None said they had only entered into nonexclusive arrangements.

Of the three diagnostic facilities who had entered into licensing-in arrangements, one said they had entered into exclusive arrangements, and one non-exclusive. Only two respondents had licensing-out arrangements, and both of these were exclusive agreements.

\footnotetext{
${ }^{244}$ All but two provided details of the kinds of arrangements entered into. Ten parties had licensed-in on a non-exclusive basis (one of these was involved in plant/animal research), and five reported having both kinds of agreements (again, one of these was involved in plant/animal research).

${ }^{245}$ One party informed us their agreement had expired, two were in negotiations or planning to enter into an agreement, one party cited confidentiality and two did not know or did not provide an answer.
} 
Exclusive licensing appears to comprise a significant portion of licensing arrangements within the industry. This was confirmed by the interview data, which highlighted the role of exclusivity in licence agreements. The interview data also confirmed that whether a licence agreement is exclusive or non-exclusive will depend largely on a number of factors including:

- the nature of the invention being licensed;

- the negotiating power of the respective parties and their position in the drug or therapy development pipeline; and

- the nature and number of potential licensees.

\section{The nature of the invention or licensed product}

Respondents reported being more willing to exclusively license where the technology was not core to their activities. A number of respondents exclusively licensed-in technology in order to shore up their patent portfolios, recognising that they were far more likely to be granted an exclusive licence where the patent holder had no intention of using the patented technology. Under these circumstances, the generally held view was that although they may not want to use the technology, this was unlikely to be of concern to a patent holder who was unlikely to use the technology and realise any value on it themselves.

Exclusive arrangements were viewed as appropriate where a licence was being sought with a particular commercial outcome or product in mind. Respondents also reported being reluctant to enter into nonexclusive arrangements where the price demanded was excessive. On the other hand, respondents were generally willing to expend significant amounts for exclusive licences.

A patent holder may exclusively license the whole subject matter of an invention, or a particular component of an invention. It is important to recall that specific fields of an invention may be separately licensed on different bases. The nature of the invention or the licensed component will be an important variable in licensing negotiations, as it will determine to some extent whether an exclusive or non-exclusive licensing deal will be more lucrative. As explained by a respondent involved in a biotechnology commercialisation company: 
Whether to licence exclusively or non-exclusively depends on the project. For example, when working with animal models most licences will be nonexclusive, devices will be exclusive. The type of licence depends on the type of technology and what you want to licence; service, compound, device etc. Each has its own quirky nature.

Gene targets may be licensed either exclusively or non-exclusively depending on how wide any applications of the gene are. A gene patent may have a number of applications and one particular application or function (such as a diagnostic or therapeutic application) may be exclusively licensed, and others non-exclusively licensed. That is, a licence over a gene patent may not be totally exclusive, but may be field specific. Such arrangements were reported to exist by a significant number of respondents from both research institutions and companies.

A number of respondents confirmed that product based inventions (or components of inventions) are often exclusively licensed, while broadly applicable technology based inventions are generally licensed on a non-exclusive basis. Platform technologies, assays, reagents such as monoclonal antibodies, and diagnostic tools for example, are generally licensed on a non-exclusive basis, while compounds and other drug targets, and particular applications of gene patents are often licensed on an exclusive basis. In short, technologies falling into category one are generally exclusively licensed, while broadly applicable technologies falling into category three are more likely to be non-exclusively licensed. Category two is more problematic, and it would appear that technologies falling into this category were in some instances licensed on a fairly limited basis. This was due to the fact that products were likely to compete, but also the other factors discussed below.

\section{The negotiating power of the parties and their position in the development pipeline}

Many company respondents said that they insisted on exclusive licences from university or biotech start-ups, while some generally bargained for assignments, exclusive licences and non-exclusive licences in that order. Many respondents stated that they just tried to get what they could. Everything seems to be negotiable, but the other factors discussed here will impact on how licensing negotiations play 
out. Respondents from universities, for example, stated that a nonexclusive licence would in many circumstances be desirable. However, in order to achieve a satisfactory licensing outcome they had to accept that given the number of research opportunities available for licence, their product would need to be licensed-out on an exclusive basis or not at all. ${ }^{246}$ Many respondents at various stages in the development pipeline had licensing arrangements with large multinational firms, and agreed that there was often little choice but to license exclusively.

In some instances, respondents said they were forced to nonexclusively license their patents where they were being infringed, or risk a challenge to the validity of their patents that they could ill afford to defend.

\section{Potential licensees}

The licensing decisions of many companies are dictated to some extent by their identification of potential licensees. For example, if only one or two companies would potentially be interested in the intellectual property, they would realise more benefit by licensing-out on an exclusive basis. Where there are "a number of players in the area”, one respondent involved in upstream research and development activities stated that they tried to license non-exclusively to extract more value from the intellectual property. Indeed, where this was the case, an exclusive licence would not be desirable unless the potential licensee had a significant share of the relevant market. Thus, identification of the markets to be serviced is an important part of any licensing decision.

Of course, the factor mentioned previously will come into play here; the ability of patent holders to enter into non-exclusive licensing-out arrangements where there are a number of licensees available, may be hindered to some extent by who the licensees are and what

\footnotetext{
${ }^{246}$ See also Henry and others, above n42; this study found that in the US, non-profit organisations are far more likely to grant exclusive licences. Sixty-eight percent of licences granted by non-profit respondents were exclusive compared with 27 percent of licences granted by private firms. The authors recognised there could be several reasons for this: the exclusive licensing mandate of the Bayh-Dole Act; a desire by universities to reduce licensing expenses; a perception that universities are more likely than their industry counterparts to licence targets for drug discovery; and the fact that private companies may generate different types of invention to non-profit institutions.
} 
arrangements they are prepared to enter into. For example, although many respondents said they would probably license-out on a nonexclusive basis if they had a choice, they admitted their choice of licensing arrangement was dictated to some extent by the demands of licensees, who often insisted on exclusivity.

An interesting comparison can be drawn with the device sector of the industry, with one respondent from a company engaged in developing devices explaining that they non-exclusively license to competitors on a regular basis, and in fact competitors are likely to be the only parties interested in licensing their technology. In many cases, these deals involve cross-licensing which seems to be common within device companies.

At the downstream end of the chain, respondents from pharmaceutical companies stated that they insisted on exclusive licences for compounds used as drug targets. Other respondents involved in downstream product development activities confirmed that they would only license-in products on an exclusive basis on the grounds that they could not afford to invest in research and development of a product under the threat of competition. Most licensees involved in licensing-in product based inventions from research institutions sought exclusive licences, and were reluctant to enter into agreements on any other basis. Price is obviously a consideration here, as products licensed on a non-exclusive basis will always be available at lower cost.

With reference to research tool patents, a number of respondents who could be characterised as operating at the downstream end of the development continuum, predictably expressed a desire for nonexclusive licences for all broadly applicable research tools. ${ }^{247}$ The Cohen-Boyer patent for recombinant DNA technology was mentioned by a number of respondents as a kind of ideal to be sought after in relation to licensing research tool patents. Exclusive licensing of research targets was more likely to be tolerated. ${ }^{248}$

By contrast, one respondent we spoke to was involved in the bioinformatics sector. This respondent could think of only one or two

\footnotetext{
${ }^{247}$ One respondent from a large pharmaceutical company stated that they would like to see guidelines for the licensing of research tools in line with the Guidelines released by the NIH. However, these guidelines have had a limited impact on the actual dissemination of patents over research tools; see above Context Chapter 2.

${ }^{248}$ See also Henry and others, above n42.
} 
examples of exclusive licensing deals involving software within the sector, and spoke of the sector maintaining an ethos of free, unrestricted access, and licensing occurring on a non-exclusive basis. $^{249}$

\section{COSTS AND DELAYS ASSOCIATED WITH LICENSING PATENTS}

A number of commentators and industry participants have agreed that transaction costs within the biotechnology industry are significant and have arguably resulted in hold-ups in technology transfer for the industry. ${ }^{250}$ Many transaction costs arise in the context of licensing intellectual property. ${ }^{251}$ Broadly defined, these include the costs of searching for a licensee or licensor, negotiating a licence, monitoring performance, and enforcing the terms of the licence and protecting against infringement. ${ }^{252}$ Additional costs may arise. For example, inventing around or conducting research and development overseas may give rise to transaction costs. It may have the effect of reducing research and development efficiency with a resulting cost to social welfare. $^{253}$ Transaction costs are invariably high in industries where many intellectual property rights have been granted, and they raise the cost of research and product development. ${ }^{254}$ One important issue for the biotechnology industry is whether companies who are able to license-in and proceed with research, nonetheless encounter lengthy and costly negotiations, because even successful negotiations delay the moment when patented technologies can be put to use. ${ }^{255}$

Transaction costs exist for all participants in the industry, and whether or not transaction costs involved in negotiating agreements are

\footnotetext{
249 Software is generally licensed for use as enabling technology. Note that proprietary databases have for the most part been licensed exclusively or semiexclusively.

250 See, for example, Eisenberg, 2001 above n21 at 232-4; C. Long 'Proprietary Rights and Why Initial Allocations Matter’ (2000) 49 Emory Law Journal 823 (hereafter Long); OECD, above n39 at 61.

${ }^{251}$ To some extent, a number of the same costs will arise in relation to assignment of intellectual property, although licensing entails a number of ongoing costs.

${ }^{252}$ Long above n250 at 827-8.

253 See Walsh, Arora and Cohen above n28 at 314-5.

${ }^{254}$ Walsh, Arora and Cohen above n28 at 314-16.

255 See, for example, NIH, above n37 at 7; OECD above n39 at 65; Walsh, Arora and Cohen above n28 at 314-9.
} 
prohibitive probably depends on the size of the negotiating parties. This suggestion was also put forward by Walsh, Arora and Cohen. ${ }^{256}$ Dealing with input technologies in biotechnology-based projects involves considerable complexity, and in relative terms this is likely to be more problematic for small biotechnology companies than larger companies, particularly pharmaceutical companies.

\section{Costs and delays associated with negotiations}

Difficulties in negotiating on a one-off basis were reported by our respondents. Often, while our respondents may not have been refused licences and been allowed access to the technology they required, access was achieved with some difficulty, or after protracted negotiations. Identifying patents which may affect the conduct of research, scrutinising these patents, approaching the patent holder and conducting negotiations are all lengthy processes, and were discussed by a considerable number of interview respondents from all three sectors. ${ }^{257}$ These problems have always existed. One respondent from a sizeable downstream company explained her perception of the situation as follows:

The number and difficulty of licences is only one factor. There is a whole range of factors...These issues happen every day; licensing has always been a real issue. It's not new.

In line with this another respondent said:

Licensing-out deals generally start with an agreed term sheet. Then you get bogged down in detail. They never go smoothly.

Although the respondents in the Walsh survey claimed that a proliferation of intellectual property rights have exacerbated costs and delays in negotiations for technology transfer, the authors considered that demand for legal resources within the [United States] industry is unlikely to have increased significantly in recent times. ${ }^{258}$ This does not mean however, that demands on in-house resources have not

\footnotetext{
${ }^{256}$ Walsh, Arora and Cohen above n28 at 316.

${ }^{257}$ See also Results Chapter 5.

${ }^{258}$ Walsh, Arora and Cohen above n28 at 316-7.
} 
increased, ${ }^{259}$ and our interview data certainly confirms that these demands have substantially increased.

In line with this, a number of our respondents had experienced increasing difficulties in conducting negotiations, particularly in terms of delays. A respondent from an upstream company who had been involved in frequent deals ${ }^{260}$ estimated that it can take months to negotiate a licence, which can damage cash flow projections. In addition, some parties may be becoming increasingly difficult to deal with. About a third of our industry interview respondents commented that they were encountering difficulties dealing with universities, and that often the problem did not lie with the scientists who were often willing to provide unrestricted access to technology and materials, but with technology transfer or business management personnel. ${ }^{261}$ At the same time, a few respondents said that they felt the increased expertise within universities and in the industry generally was actually streamlining the negotiation process.

In negotiations generally, the same terms and conditions are often included when negotiations start as a kind of "wish list", so that negotiations have to take the same path time and time again. ${ }^{262}$ Thus, costs and delays in achieving an acceptable licensing or assignment outcome were reported. In a number of cases, it was considered likely that the force with which international companies are able to bargain contributed to these costs and delays to some extent. And as a licensing consultant pointed out, often the path that negotiations take will be technology dependent. If a research institution or small biotechnology company is competing with a number of other technologies their licensing-out position will not be as strong. On the other hand, if their technology is sought after, they will hold a valuable bargaining chip in negotiations.

Theoretically, licensing is less likely to be a viable option where the transaction in question is low-value. Transactions may be worthwhile despite high transaction costs where the transaction is a high-value

\footnotetext{
${ }^{259}$ This was recognised by Walsh, Arora and Cohen above n28 at 316; one of their respondents from a large pharmaceutical company referred to the significant inhouse resources demanded by the biotechnology division of the company compared with the small molecule division.

${ }^{260}$ This respondent had had to negotiate access to PCR in the 1980s and referred to the difficulties his company went through.

${ }^{261}$ These issues are canvassed in detail in Results Chapter 3.

${ }^{262}$ See also Eisenberg 2001 above n21 at 223; NIH Report above n65 at 2.
} 
one, but in some cases the transaction costs of the exchange will exceed any gains that could be realised and the transaction is unlikely to proceed. ${ }^{263}$ This may be the case whether multiple low value agreements are required for each research project (ie, an anticommons effect), or when particular high value research tools are difficult to gain access to. ${ }^{264}$ Eisenberg contends that this may be a particular problem for universities. Although deals on behalf of most private companies are likely to ultimately go forward and in many cases it is possible to invent around required technology, this may not necessarily be the case for university scientists. Eisenberg suggests that even in the case of private firms, terms and conditions sought in negotiations may prove to be a stopping point, and the speculative value of much follow-on research makes negotiations difficult. ${ }^{265}$

Our data aligns with this in that respondents from both company and research institutions were unlikely to pursue costly negotiations if the transaction in question involved technology that was peripheral to their research interests. A number of respondents reported that where a research project has the potential to produce a high value output, costs and delays in conducting transactions will generally not be impediments to successful bargaining. However, projects that could be classified as being of marginal or intermediate value to a company were often derailed where the costs of negotiation proved prohibitive. We did not have any evidence on this point from research institutions, although this may be because research often proceeded in the absence of negotiations in that an informal research exemption was relied on.

\section{The cost of monitoring infringement}

Many of our company interview respondents confirmed that they expend considerable resources monitoring infringement. Monitoring infringement was widely acknowledged to be difficult, however often this cost of enforcing intellectual property was seen as worthwhile because of the opportunity for generating licensing revenue. Walsh, Arora and Cohen found that litigation costs may also prove considerable in terms of out-of-pocket expenses, and opportunity cost. $^{266}$ However, few of our interview respondents were involved in,

\footnotetext{
${ }^{263}$ This point is explored in some detail by Eisenberg 2001 above n21 at 232-4.

${ }^{264}$ Ibid at 234 discussing the findings of the NIH study in relation to universities.

${ }^{265}$ Ibid at 232-3.

${ }^{266}$ Walsh, Arora and Cohen above n28 at 315; litigation is a long and costly process, not only because of the costs of running litigation, but also in terms of the burden it imposes on company personnel.
} 
or had been involved in, litigation at this stage. ${ }^{267}$ Often, the problem was one of a lack of resources in that many patent holders simply do not have the resources to protect and enforce their intellectual property.

\section{Inventing around}

Finally, inventing around may involve a number of transaction costs. Diverting projects to avoid infringing intellectual property undoubtedly involves some cost to researchers and companies as well as wasted resources There may also be some social cost in that projects with social value do not proceed. We found that the industry is engaged in significant inventing around activity, so it would be fair to assume there are significant costs associated with this from a social perspective. $^{268}$

\section{RESTRICTIVE TERMS}

Two questions in the company survey were designed to elicit information about restrictive terms in licence agreements. The first question asked whether respondents had ever licensed-in a patent on terms that they considered restrictive. Nine respondents answered yes to this question, (18 percent) and one answered 'expect so'. Of the nine respondents, five reported that the terms related to cost or royalty structure, $^{269}$ (10 percent of total respondents) and three reported that problematic terms were those related to reach-through rights or grant backs (six percent of total respondents). ${ }^{270}$ One respondent reported the licence was blocking, one complained of field of use restrictions, and one reported species application restrictions.

The second question asked respondents whether they had ever abandoned licensing-in a patent due to restrictive terms contained in the licence. In other words, this question sought to ascertain whether respondents had ever encountered a breakdown in licensing

\footnotetext{
${ }^{267}$ In a 1999 survey, Ernst \& Young found that some eight percent of companies surveyed had been involved in patent infringement litigation in the 12 months preceding the survey. This figure was considered to be fairly low by international standards, but was unsurprising to the authors of the Report given Australia's low levels of corporate litigation generally; Ernst \& Young, 1999, above n1 at 35.

268 See below, Results Chapter 7.

${ }^{269}$ Note that one of these respondents was involved in plant/animal research.

${ }^{270}$ See the discussion on reach-through rights below.
} 
negotiations due to the terms insisted on by the patent holder. Seven respondents stated that they had abandoned licensing-in a patent, (14 percent) and four of these reported discontinuing a particular aspect of research (eight percent of total respondents). A number of these seven respondents were Australian based companies of medium size (with reference to number of employees and revenue), ${ }^{271}$ and all but one had significant patent portfolios ranging from five to 150 plus patents. $^{272}$

Interestingly, all but one of the respondents who reported that they had been refused a licence, also responded in the affirmative to at least one of these two questions. Fourteen companies in all had encountered what they considered to be restrictive licensing, or been refused a licence. Clearly this number is not as significant as one might expect, and again might be due to the fact that companies were unlikely to seek licences they did not think they would be able to obtain, or be able to obtain on reasonable terms. As one research institution researcher we interviewed put it:

We have had situations where we fail to get a licence - it is not refused but it clear that we wouldn't be able to get a licence. This can have a severe impact on the research project. Generally the problem is to do with the terms - outrageously high financial terms, out of all proportion to the value of the IP. However, this is a rarity. In one case the company appeared to want to take a deliberately blocking approach.

We included a question on the survey that asked whether difficulties encountered in licensing-in patents had an inhibitory effect on research. Ten respondents were of the view that there was some inhibition of research due to difficulties in licensing-in, and only five of these were among the 14 respondents who had also reported a refusal or restrictive licensing issue. The remainder of these 14 respondents clearly did not feel that any problems they may have had in licensing-in had an inhibitory effect on research. They were relatively large companies with significant patent portfolios, so it is likely that their companies had the resources to redirect research in the event that they did encounter difficulties in licensing.

${ }^{271}$ One of the respondents did not provide the basic information as to the company's activities on the grounds that they considered it to be confidential and possibly identifying.

${ }^{272}$ One respondent did not report any granted patents or patent applications. 
Many interview respondents referred to difficulties in negotiating licences, and often these difficulties stemmed from the fact that they held an inferior bargaining position. As a licensing consultant explained:

The choice of what licence to use depends on who is more powerful. We had one deal where the US licensor insisted that we had to use their agreement. It was ambiguous because they tend not to use English as precisely as us. But they refused to look at our licence.

Of the respondents who discussed licence terms, the same terms appeared to be problematic in a number of instances. ${ }^{273}$ Although parties to licensing arrangements seek to have some parity between licensing deals in which they are involved, respondents acknowledged that every deal is different. Although the terms included in licences tend to be more or less equivalent, most negotiations are in effect started afresh, as various companies engaged in different activities, and licence deals require different coverage. In the opinion of one respondent, "The market is ad hoc; this is rather inefficient. The transaction process lacks marketplace mentality." Transaction costs involved in licensing mean that the process of licensing is resource intensive, and successful outcomes relatively costly. ${ }^{274}$

Whether or not negotiations could overcome differences of opinion in the terms to be included in licence agreements seemed to depend to a large extent on whether the technology for which a licence was sought was core to the licensee's research interests. As one respondent put it: "We have had situations when terms are too onerous. If peripheral to your own research interests, you simply part company. If core, then you fight for it and be prepared to share the spoils."

Many of the terms that can be problematic in licence agreements were outlined in Results Chapter 2. When asked whether restrictive terms had been imposed in licence agreements, respondents highlighted a number of those terms. Field of use restrictions, for example, were frequently contentious and regarded by licensees as problematic.

\footnotetext{
273 See also Eisenberg 2001 above n21 at 223-50.

${ }^{274}$ See section above dealing with 'Costs and Delays'.
} 
Prohibitive royalty structures can be deal breakers, particularly from the large pharmaceutical company perspective. One respondent from this sector stated that they would not pursue a deal with a complex royalty structure particularly for unvalidated targets. An even bigger risk is that if a licensor asks too much the validity of the patent may be challenged and the patent may be lost. One respondent gave the example of the Cohen Boyer patent to demonstrate the importance of setting an appropriate royalty fee. She noted that this covered basic recombinant DNA technology and was probably invalid, but because the royalty rate was so low everyone paid. The terms that respondents considered to be most restrictive, however, were terms claiming reach-through rights.

\section{Reach-through rights}

Other studies have found that reach-through rights in licences are one of the most pervasive issues that arise in licensing negotiations, and are problematic for participants from all industry sectors. ${ }^{275}$ Reachthrough rights in licence agreements may take the form of rights to royalties over future inventions, exclusive licences over future inventions or ownership (or a licence) of intellectual property over future inventions. ${ }^{276}$ Usually they are contained in licences of inventions that can be classified as fairly upstream, or material transfer agreements (MTAs). They often give the licensor broad rights to inventions that may not have been foreseen at the time the licence was entered into. The issue of reach-through rights in the context of licence stacking is canvassed in detail in Results Chapter 5.

In relation to rights to future inventions or improvements, one respondent involved in frequent licensing-out deals stated that:

We have a number of licences where there is provision for the new technology to be licensed back to us. For

\footnotetext{
${ }^{275}$ See NIH, above n37. Reach-through rights were problematic for both private sector and university respondents in this study. Many complaints were encountered in relation to broad spectrum research tools such as databases, instruments and reagents that could be used in a variety of research questions, but they were certainly not limited to these tools. From the perspective of private firms, reachthrough rights were generally a method of controlling the risks associated with providing research tools to scientists or NIH-funded institutions; see at 12-16. See also Straus, Holzapfel and Lindenmeir, above n35 at 17 (licence negotiations are more cumbersome due to insistence on provisions giving reach-through rights).

${ }^{276}$ See Heller and Eisenberg, above n131 at 699; Eisenberg 2001, above n21 at 230, NIH, above n37 at 8.
} 
example, this might include gene targets or gene therapy using our technology. We want the first option to commercialise or at least to get hefty royalties. All our licences have provisions dealing with background and foreground intellectual property and licensor and licensee improvements. These are at the core of negotiations and are the hardest part. We try to get as much downstream as possible. This is the core of our growth path. We need to be careful how we deal with it. It can be a deal breaker.

These terms appear to be problematic in a large number of negotiations. Respondents from most industry sectors made some reference to these provisions, a large number of respondents involved in licensing-out stating that they insisted on such rights, other respondents stating that they tried to avoid them. One patent attorney we interviewed was involved in a deal that almost broke down because of reach-through rights to improvements; his comment was that "The patentee wants as much as possible whereas the licensee wants as little as possible.” A licensing consultant explained:

The licensor's first position is to own any improvements and grant back a licence to the licensee. The idea for this is that if they give out a number of licences they are able to put all the technology together. However, the licensee wants to own the technology and license back to the licensor.

Most respondents who were involved in a high volume of deals did encounter these provisions regularly. A number of respondents specifically stated that they try to keep away from such terms when licensing-in because they can be so problematic. In instances where they licensed-in, research institution respondents tried to avoid such terms because they would have the effect of detracting from their exploitation of any improvements or new technology developed by them. Technology transfer personnel in particular, appear to be putting up more resistance to the inclusion of reach-through provisions in agreements that license-out their technology. In a significant number of cases, however, provisions giving reachthrough rights were still included, and one public sector researcher we interviewed stated that in his experience there is a general trend toward these sorts of agreements becoming more restrictive. 
One respondent from a university technology transfer office offered the following in relation to research collaborations:

Rights to future intellectual property was a Pandora's box in the old agreements. The problem here is when we have an agreement that involves research done by us and there are rights to improvements, essentially it deals with licensing of intellectual property that doesn't yet exist. I think that if something is separately patentable it is more than an improvement. We have to be very careful in these deals. We need to define what an improvement means. There must be a threshold where the intellectual property is no longer a mere improvement in which case the company should not own it. We are not strictly contract researchers therefore improvements which are separately patentable should go to the project. This is one of our biggest problems. We are continually battling with these types of things. The companies have wanted to have rights to future intellectual property. However, things are changing. In the past when deals were done researchers were not told much. There is much more transparency now.

Only two respondents to the research institutions survey stated that they had encountered difficulties when licensing-in due to reachthrough or ownership provisions, (nine percent) and no diagnostic facilities reported entering into licences containing such terms. In many cases, however, scientists rather than technology transfer personnel who probably encounter more difficulties negotiating these terms, may have completed the surveys, particularly in relation to the research institutions survey. ${ }^{277}$ Given this, it may be that this figure is not representative of the actual situation. It may also be the case that these terms are becoming less contentious as they become more common and are more readily accepted. There were also reports by both research institution and company interview respondents that universities more frequently seek to include provisions giving them reach-through rights. $^{278}$ Another comment from a university technology transfer officer was:

\footnotetext{
${ }^{277}$ A similar conclusion was drawn by the NIH; NIH, above n37 at 9 .

${ }^{278}$ Consistent with this finding, the NIH Working Group found that university technology transfer personnel often start at the same point as private firms,
} 
In the MTAs that we have negotiated with some US institutes they have tried to get in terms saying that they want rights to anything coming out of our research. We fight against this. At the same time we would want a clause of that nature in our out-licences. It might be for licensing back, joint ownership etc. It is a matter for negotiation.

This encapsulates what we heard from participants in the industry generally. While many respondents saw the obligation to give rights to future inventions as onerous, at the same time they sought reachthrough rights as a matter of course. This emphasises that perceptions depend very much on the ability of industry participants to bargain for a particular outcome.

Where universities are committed to give rights to future intellectual property as a condition of a licence or MTA, they may have difficulty attracting funding from other bodies for any research that uses the patented technology or materials. ${ }^{279}$ This may decrease incentives to engage in research if rights to outcomes are already given away.

Again, it would appear that a number of variables will determine whether or not reach-through rights to future inventions are likely to be included in a licensing arrangement:

- the nature of the technology or product being licensed;

- whether or not the licensed technology is core to the activities of the licensee; and

- $\quad$ the relative bargaining power of the negotiating parties.

The nature of the licensed technology

To a large extent, whether or not reach-through rights are sought will depend on the technology being licensed. If, for example, a university is in the business of licensing reagents, it is unlikely that reachthrough rights will be sought. Generally terms claiming reach-through rights are most problematic when research tools and materials are being licensed-in (that is, technology falling into category three). A number of respondents also made the point that problems are less

presenting agreements that contain many of the same terms they complain about receiving from private firms; NIH, above n37 at 10-11.

${ }^{279}$ See also NIH, above n37 at 8. 
likely to arise where the licensor and licensee are coming from two different platforms, because in this instance it is easier to divide the spoils that come from improvements or new inventions. If the improvement is to a particular platform, the owner of that platform will be entitled to the intellectual property. As one downstream company respondent stated, platform companies are unlikely to request rights to inventions developed by them.

A distinction should also be drawn between improvements and new inventions. While both are separately patentable, more protracted disputes may arise over rights to so-called "new" inventions. Although the issues that arise in respect of both are similar, arguably reach-through rights to new inventions are likely to be more problematic. $^{280}$

Finally, the cumulative nature of biotechnology research tends to lend itself to disputes about rights to future inventions. Respondents from device companies who develop through to end-product stage, reported that they had no difficulties with reach-through rights to future inventions given that no new intellectual property is generated by their licensees.

\section{Core technology}

A related point is whether or not the improved technology is core to the activities of the parties. If so, they are more likely to dispute the inclusion of reach-through rights to improved technology. Likewise, the inclusion of reach-through terms is likely to be more desirable to parties who are licensing-out core technology. Respondents indicated they would be particularly opposed to reach-through rights in respect of licences over inventions falling into category three. Although strong opposition to reach-through rights was frequently voiced, there was likely to be less issue with reach-through rights over technology falling into category one.

\section{Relative bargaining power}

Most respondents who discussed reach-through rights to future inventions stressed that the inclusion of provisions dealing with reach-through rights is generally a matter for negotiation. The bargaining strength of the parties will be an important component of any negotiation on reach-through rights to future inventions. For

\footnotetext{
${ }^{280}$ On the issue of what constitute improvements and what might constitute new inventions, see M. Lemley 'The Economics of Improvement in Intellectual Property Law’ (1997) 75 Texas Law Review 989 at 1007-1013.
} 
example, one respondent from a technology transfer company suggested that large pharmaceutical companies are far less flexible in negotiations than small biotechnology companies. As he put it, "It is a dominance issue: big party versus small party dealings.” In some instances, a licensee will have no alternative but to agree to joint ownership. This confirmed the views of other company and research institution respondents. This respondent also made the point that in negotiations in which he had been involved, research institutions are generally the weaker party, even if their technology is 'hot'. This is because they don't have deal precedents, and usually get a negotiated outcome that is less favourable to them than it could be.

On the other hand, many parties licensing-in patents, particularly research tool patents, and materials, will be forced to give rights to future inventions to the patent holder or owner of materials. ${ }^{281}$ In some instances, they will have to compromise and agree to joint ownership in order to conclude negotiations and enable their research to proceed.

\section{FAILURE TO EXPLOIT PATENTS}

We asked interview respondents about patents that were granted but not exploited. As reported above, a number of respondents stated they could not see the sense in retaining patents but not exploiting them. At the same time, many respondents either held patents they did not exploit, knew of patents that were being held but not exploited, or speculated that this was certain to be the case. Some respondents suggested that larger companies might employ the strategy of patenting in order to exclude competitors from areas of research they considered they might enter at some stage. The position seems to be that many respondents we spoke to employ a defensive patenting strategy and in effect "fence in" their intellectual property position by obtaining families of patents. $^{282}$ As one respondent from a downstream company put it, "[I am] positive about patents, but there is definitely a lot of over-patenting going on.”

\footnotetext{
${ }^{281}$ See also R. Eisenberg 'Streamlining the Transfer of Intellectual Property Rights' (1999) 74 Academic Medicine 683.

${ }^{282}$ See also D. Dierker and P. Phillips 'The Search for the Holy Grail? Maximizing Social Welfare Under Canadian Biotechnology Patent Policy’ (2003) 6 IP Strategy Today 45-62.
} 
We sought to ascertain the level of defensive patenting taking place in the industry. By defensive patenting, we mean patenting with a view to building a proprietary position that enables freedom to operate. We asked survey respondents whether they had ever applied for a patent for strategic reasons. This may include patents applied for where there was no intention to exploit a patent. Twenty-one of the 49 company respondents said that they had (43 percent). This figure is not surprising given what we know about the high levels of patenting within the industry: defensive patenting strategies are crucial in order to ensure freedom to operate. Defensive patenting is far more prevalent within the company sector than other sectors. Only five of the research institutions surveyed said that they had applied for a patent for strategic reasons (22 percent), while one diagnostic facility answered this question in the affirmative (five percent).

Most interview respondents engaged in patenting agreed that they patented very broadly. A number of respondents reported that their companies had patents (or licences) on their books that they did not exploit. Their research options were so rich that they had many patents they just didn't have the resources to exploit themselves. Gene validation targets, for example, are being generated at a rapid pace. In addition to this, some respondents reported that they had identified technology they did not wish to see exploited, and paid the patent holder to sit the intellectual property on a shelf and to not seek licensing opportunities.

Where patent holders did not exploit patents, they resolved this nonexploitation in some instances by either letting the patents lapse or licensing them out. One problem appeared to be that it wasn't often that licensing opportunities were sought, or available. In the case of many academic institutions, potential licensees had so many research opportunities, that many patents were not taken up and exploited. Marketing technology and products to overseas companies is difficult. If a potential licensee approached the patent holder, often this led to some sort of negotiated arrangement. If not, often the patents stayed on the books of the patent holder. It may be the case in this instance that these patents were not worth working in any case in the sense that a commercial outcome was unlikely. Alternatively, it is possible that they were simply not on the radar of potential investors, or that the patent holders did not actively seek licensing opportunities.

One respondent considered that in many cases there is a lack of effort on the part of patent holders to license-out their technology. 
Alternatively, he suggested that research institutions in particular, file patent applications fairly indiscriminately due to pressure to generate income. ${ }^{283}$ A trade association representative, who criticised the tendency of research institutions to patent inventions without a commercial outcome in mind, shared this view.

A number of respondents commented that they could not see the point of obtaining patents (or licences) and not exploiting them. Maintaining patents in this instance was a waste of valuable funds, and their view was that they could not afford licence fees unless they intended exploiting the licensed technology. The main value of a patent was, to many respondents, a licence agreement or preferably, a number of licence agreements. This was particularly the case where the technology was core to the interests of the company or institution. Nevertheless, there was some divergence of views in respect of nonexploitation.

Some respondents let patents sit on the shelf if they did not wish to currently exploit them, but thought they may be useful down the track. One respondent involved in a technology transfer company suggested:

There are thousands of cases of non-exploitation of patents. For example, it may be that research is the priority and commercialisation is non-core. Why obtain patents? Usually it is a push from one person, a view that they may be useful one day. You need to look systematically for what to keep, what to dump, etc. For example, if a provisional has been filed, you need strong interest to keep it going.

On the issue of licensed products and technology that are not exploited, one respondent from an upstream company stated that his company did not engage in much licensing-in. However, they would seek an exclusive licence where patents owned by other researchers and used for different purposes, created holes in their patent portfolio. In such circumstances:

You don't necessarily want to use the technology, but without it someone else could burrow into your area. Other companies are willing to [licence to you] if the

\footnotetext{
${ }^{283}$ See further Results Chapter 3.
} 
patent is of no use to them whatsoever. It gives them something for it that they wouldn't otherwise have. If the technology is not core to the organisation you are approaching it is not too difficult.

In summary, respondents who indicated that they had patents or licences they did not exploit, indicated that this was for two main reasons:

- they considered the technology may become useful at a later stage;

- they wished to prevent someone else from exploiting the technology.

Aside from these motivations for sitting on technology, few respondents maintained technology they had no intention of exploiting. Although respondents in general did not express concern that their technology would become obsolete, this was specifically mentioned as a problem by respondents from the device and bioinformatics sectors of the industry. Thus, concern at technology losing its value was not generally referred to as a motivation to license-out. The short life span of technology in the device sector prompted vigilant management of companies' patent portfolios. In the bioinformatics sector, the rapid pace of technology made intellectual property protection of dubious value.

Another university technology transfer officer had encountered negotiations for deals where the company was attempting to license to stop the product being developed by the university from being commercialised. Revocable licences are one way of safeguarding patents in which patent holders have a strong research interest by preventing licensees obtaining licences with no intention of exploiting them.

Another safeguard exists in that the Australian Patents Act 1990 provides for the issue of compulsory licences for failure to exploit an invention. More specifically, an application for a compulsory licence can be made where the reasonable requirements of the public have not been satisfied, and the patent holder has failed to provide a satisfactory explanation for failing to work the invention. ${ }^{284}$

\footnotetext{
${ }^{284}$ Patents Act 1990 (Cth) s133(2).
} 
Nevertheless, it seems that there are still some patents that are not exploited, and it may be that patent holders and licensees have no choice but to pursue the most commercially promising lines of research. There may, however, be some social cost where patents that may not lead to a commercially valuable outcome but are nonetheless relevant to some socially valuable research, are not exploited. ${ }^{285}$

\section{SUMMARY}

There is certainly evidence of exclusionary practices within the industry, but it must be remembered that the essence of a patent right is the right to exclude others. Given this, we do not find it surprising that respondents complain of some restrictions on free access to patented technologies and products. This is despite the fact that there are a significant number of patents within the industry that block research to some extent.

Our data demonstrates that there has been some evidence of restricted access to patents within the industry. This is particularly the case when we consider the technology to which access is restricted. Few of our respondents complained about access to technology being restricted where that technology fell into category one. They accepted this as a necessary element of the patent system, and given (generally speaking) their support of the patent system, were content to bear this cost.

It also became evident that technologies falling into category three have been widely disseminated. In most cases, references to these technologies were to the foundational technologies discussed in Context Chapter 3. Category two presents more difficulties in that there may have been some instances where access was restricted. What our data does not tell us is whether the technology was nonetheless being exploited, which would, to a degree, lessen the social cost that restricted access entails.

However, it is probably fair to say that few of our respondents were concerned at the long-term effects of restricted access, and in most cases research was able to proceed albeit in a modified fashion. In a number of instances respondents indicated that their research was able to proceed, but the modification of research meant that various lines

\footnotetext{
${ }^{285}$ See further the discussion on compulsory licensing in Outcomes Chapter 1.
} 
of research which could have led to promising results were not pursued. Of course, it is difficult to gauge the effects of exclusionary practices without knowing where particular lines of research are likely to lead. It should also be noted that access issues are alleviated to some extent by rapid technological advance within the industry which makes it more likely that alternatives to foundational inventions will be developed. Walsh, Arora and Cohen concluded that future problems resulting from exclusionary licensing practices in the United States could not be ruled out, and called for continued vigilance to defend open science. ${ }^{286}$ We would endorse this finding.

${ }^{286}$ Walsh, Cohen and Arora, above n28 at 335. 


\section{RESULTS CHAPTER 5: ANTICOMMONS ISSUES}

To reiterate, the essential preconditions for an anticommons within a particular industry are:

- a proliferation of intellectual property rights over essential research inputs; and

- high transaction costs that make exchanging these rights difficult.

The existence of an anticommons in the medical biotechnology industry is likely to be particularly problematic because of the important role that this industry has in providing innovative diagnoses, treatments and therapies to alleviate human suffering caused by disease. An anticommons in this industry has the capacity to slow the pace of innovation, which is most unlikely to be in the public interest.

There may be a number of different manifestations of an anticommons, each of which has the capacity to impede research to a particular degree. First, the most extreme manifestation is project abandonment. This is more likely to occur where there are multiple overlapping intellectual property rights than when there are small numbers of rights. If negotiations are required to be undertaken with a number of parties, the risk of negotiation breakdown is increased. If negotiations break down with any one of these parties, the investment of time, effort and money in the project will need to be reassessed. Depending on the stage at which breakdown occurs, this may mean that projects are either not commenced or are abandoned at some stage into the research process. The later projects are abandoned, the greater the waste of resources. In other instances, considerable research effort may need to be put into inventing around the area protected by intellectual property rights in order to enable the project to proceed. As the number of relevant intellectual property rights increases, the task of inventing around becomes more onerous, and project abandonment may become inevitable.

Secondly, to a lesser degree, an anticommons may exist even when negotiations are concluded successfully with all relevant intellectual 
property rights holders. If multiple in-licences are entered into, requiring the payment of licence fees and/or royalties, projects may be able to proceed but at considerable cost. If multiple commitments are made to provide a percentage of royalties on downstream products, the risk is that this royalty stacking will make the project outcomes so unattractive to potential downstream partners that technology transfer is not feasible. Similar difficulties are likely to arise if reach-through right stacking occurs. Hence, greater levels of encumbrance will reduce the attractiveness of the technology and lower the probability of it reaching the market.

Thirdly, due diligence may lead parties to avoid particular research areas entirely or redirect their research efforts away from heavily encumbered areas in order to avoid the need to negotiate access. In this way, research funds are not wasted on projects that are later abandoned and breakdowns in negotiations and royalty stacking are avoided. Nevertheless, anticommons issues still arise, because projects that may otherwise be in the public interest are not undertaken.

The anticommons doctrine is sound in theory. However, there is little in the way of empirical evidence to show that an anticommons does, in fact, exist in the medical biotechnology industry, and, if it does exist, that it is, in fact, slowing the pace of innovation. We have already discussed some of the empirical research that has been conducted to analyse this issue in the United States ${ }^{287}$ and Europe. ${ }^{288}$

In this chapter we address this issue from the Australian perspective. Before we discuss the question of whether and to what extent an anticommons actually exists in the Australian medical biotechnology industry, we first consider the question of whether or not the preconditions to an anticommons exist in Australia. We then discuss a range of factors that are likely to be indicative of an anticommons. In determining which factors to consider, we used the theoretical manifestations discussed above, and were also guided by the other empirical studies of these issues. We particularly wanted to know whether there was evidence of:

- increasingly onerous patent searching obligations;

\footnotetext{
${ }^{287}$ Walsh, Arora and Cohen, above n28; NIH, above n37.

${ }^{288}$ Straus, Holzapfel and Lindenmeir, above n35.
} 
- excessive numbers of in-licences, project abandonment and/or redirection of research efforts;

- royalty stacking; and

- reach-through right stacking.

\section{PRECONDITIONS TO AN ANTICOMMONS IN AUSTRALIA}

John Walsh and his colleagues refer to a number of factors that could be used to characterise an environment in which the preconditions for an anticommons exist. Most importantly, they say that the essential precondition is the existence of multiple patents covering different components of a single product, its method of manufacture, or inputs into the process through which it is discovered. ${ }^{289}$ As already discussed, there can be little doubt that the patent landscape has become dramatically more complex over the last ten years for the following reasons:

- a large increase in the number of patent applications and granted patents. For example Walsh, Arora and Cohen cite an increase from 2000 issued patents in the United States in 1985 to 13000 issued patents in $2000 .^{290}$ Similarly the OECD has estimated that between 1990 and 2000 the number of United States biotechnology patents rose by 15 percent each year. The increase was 10 percent per year in Europe and five percent worldwide. ${ }^{291}$ Whilst the number of Australian patents has not risen quite so dramatically, there has, nevertheless, been a rapid and significant rise, ${ }^{292}$

- an increase in the number and diversity of companies and other industry sectors filing patents;

- granting of broad patent claims over foundational patents. Whilst patent offices in some jurisdictions are much less willing now to allow broad claims than in the past, broad patents granted in the 1990s remain active. Should any of these patents be challenged in the courts, it is likely that

\footnotetext{
${ }^{289}$ Walsh, Arora and Cohen above n28 at 293.

${ }^{290}$ Walsh, Arora and Cohen, above n28 at 293.

${ }^{291}$ OECD, above n39 at 8.

292 See Context Chapter 3.
} 
particularly broad claims will not be upheld. ${ }^{293}$ However, we have seen in Part 1 of this Report that challenges to biotechnology patents are extremely rare in Australia and it is perhaps unlikely that such challenges will increase in the future. There is little incentive for competitors to challenge patents if it means that undesirable precedents will be set. The cost and risk of litigation will deter others, particularly when the patent holder has litigation insurance; ${ }^{294}$

- filing of a number of defensive patents in respect of a single invention. Some of our interview respondents commented that their patent strategy included filing a number of patents around their key technology to create a "picket fence";

- granting and enforcement of research tool patents. Clearly, the main purpose of research tool patents is to impose restrictions on the use of these novel technologies in the research context. If these are enforced aggressively there is a real danger that downstream research will be restricted.

Together, these factors suggest that there are far more impediments to the conduct of a successful research project than was the case 10 years ago and that for any given research project more in-licences will be required than used to be the case. We discussed in Results Chapter 4 some of the issues that arise in negotiating individual licence agreements and the problematic terms of such agreements, particularly those relating to royalty rates and reach-through rights. What we are concerned with here is that, if there are a number of relevant patents and if it is necessary to enter into multiple inlicensing agreements, there is the potential for an anticommons.

An anticommons can only exist if the relevant patents which lead to it exist. Potentially, a large number of candidate patents could fulfil this role. However, we have already noted in Context Chapter 3 that a number of the research tool patents that are said to be aggressively enforced in the United States have either not been filed in Australia, or, where applications have been filed, the patents have not been prosecuted. Clearly, these factors are likely to reduce the detrimental effects of restricted access on innovation in Australia, as discussed in Results Chapter 4. They may also provide some guidance as to the

\footnotetext{
${ }^{293}$ Walsh, Arora and Cohen, above n28 at 299 cite the EST patent as examples of patents likely to be construed narrowly by the courts.

${ }^{294}$ Note that Genetic Technologies Ltd, the holder of the junk DNA patents, has such insurance and is reported to use it as a bargaining chip in licence negotiations. See ABC Four Corners, above n7.
} 
presence or absence of an anticommons in Australia. If a number of research tool licences are required to be entered into for a particular research project to proceed, the preconditions for an anticommons are likely to exist. If the relevant patents do not exist or are not being enforced, there is no requirement to licence-in. However, these propositions should be treated with some caution for a number of reasons. In particular, the patents referred to in Context Chapter 3 are only a small sample of a large number of research tool patents already filed and granted in the United States. New research tools will continue to be developed and it is likely that new applications will be filed here as the awareness of the growth of the Australian industry increases.

We suggest that although there are gaps in patenting of research tools in Australia, it would be premature to conclude that the preconditions for an anticommons are entirely absent. On this basis, we consider that it is necessary to explore further whether any of the hallmarks of an anticommons can be found in the Australian industry.

\section{PATENT SEARCHING OBLIGATIONS}

\section{Conducting patent searches}

Our survey results show that 84 percent of company respondents routinely conduct patent searches to ensure that their research does not infringe patents held by others. However, the percentages are much lower for research institutions (50 percent) and diagnostic facilities (12 percent overall, 23 percent of those facilities conducting research). One explanation for these lower percentages for research institutions and diagnostic facilities is the commonly held view that patents don't block research. For example, one research institution respondent commented that:

In the academic area most people don't think about infringement. We never do patent searches. You only do them if you're about to put in a patent yourself.

This is perhaps a naïve view for a number of reasons, including: 
- the United States decision in Duke $v$ Madey, ${ }^{295}$ discussed in Context Chapter 3, creating uncertainty abut the ambit of the experimental use exemption in the United States;

- the lack of clear guidance as to the existence of a research exemption in Australia; and

- the increasing willingness of companies to make the hard decision (from a public perception perspective) of enforcing a patent against research institutions. ${ }^{296}$

It would certainly be foolhardy to presume that research with a commercial goal is immune from infringement proceedings. ${ }^{297}$

The general view in the industry is that searches are expensive but necessary to ensure freedom to operate. As one respondent said "you don't want to spend 18 months developing new technology and then a competitor gets an injunction against you.” Another said:

Patent searching is the same as title searching if you're in the business of selling land. It is necessary to spend money on professionals and build up a network. It hasn't really become more onerous for us. It would be crazy not to use professionals. Searching happens on a weekly basis. After the first couple of years we now get very few surprises.

\section{Time for undertaking patent searches}

The time at which searches are undertaken in relation to particular research projects is highly variable. Most industry players have procedures in place to search the patent databases regularly, as often as once per month, to ensure that they have a clear view of the state of the field. Even then, occasional surprises still come up. Of course, when the time comes to file a patent, further searches will have to be done to satisfy the prior art requirements.

\footnotetext{
${ }^{295}$ Madey, above n87.

${ }^{296}$ Comments made by Francis Collins and others in response to GTG's pursuit of licences with academic institutions illustrate the depth of feeling about this issue. See ABC Four Corners, above $n 7$.

${ }^{297}$ Note that a survey is currently being conducted by the Advisory Council on Intellectual Property, seeking views on the relationship between the patent system and research and development, including the extent to which experimental use is exempt from infringement. Available at:

http://www.ipaustralia.gov.au/about/acip_survey.shtml (accessed 5 December 2003).
} 
A number of company respondents commented that they do detailed searches as soon as they have an interest in a new research project, as part of their due diligence. For example, a respondent from an upstream company commented that the company generally ensures freedom to operate first by doing full due diligence for every project. Decisions are then made on what licences are required, what patents can be worked around, what patents can be ignored and whether or not the project will go ahead. Many companies have their own in house systems set up for patent watches. Patent attorneys also provide this service to some clients.

In research institutions it is generally expected that the scientists themselves will know what is going on in their field through normal scientific means of publication searches, attending conferences etc. It would seem to be quite rare for patent searches to be done at the early stages of research projects. A number of respondents expressed the view that it is unnecessary to ensure freedom to operate at this stage. For example, one technology transfer officer said that:

When research projects start we don't do patent searches at this stage. It is far too early. It is not done in a directed or focused way at this stage because we are a basic research institute. We search when the results start to look interesting.

A patent attorney added that:

The little guys come just before publication and haven't done any searches yet. However, they are generally fairly aware about what is happening in the literature and wouldn't tamely follow someone else's research - they are quite aware of what is out there. Often the most damaging publications are their own.

More commonly, searches will be done when the commercial potential of a particular research project becomes apparent, which is when the option of lodging a provisional patent application arises. One respondent from an upstream company similarly commented that searches are not done until after a researcher has come up with something that is commercially useful. However, he added that as the company grows it will be doing patent searches before embarking on further research programs. In this way, intellectual property can be 
mapped, holes can be found in intellectual property held by competitors and new directions can be found for research.

\section{Complexity of the patent landscape}

All of our respondents were of the view that patent searching is an onerous and expensive process. These views mirror the findings in the Walsh study. Their respondents generally acknowledged that the patent landscape has become more complex and that there are often a large number of patents potentially relevant to a given project. ${ }^{298}$ One of our downstream company respondents put the cost at tens of thousands of dollars per year and noted that the complexity of searching is increasing. The vagueness and openness of the terminology used in patents adds to the difficulties. Another respondent commented that due diligence is becoming more difficult, particularly for a small company with a small team. He mentioned one target that has 350 patent applications pending over it. Added to this, he noted there may be method of use patents.

A patent attorney noted that search requirements are expanding massively and that approximately 10 times more searching is done now than five to 10 years ago. Whilst the time and cost of searching depends very much on the class of claims, she estimated that an average freedom to operate search takes about two to three weeks in Australia at a cost of around AU\$3,000. The cost of paying for a patent attorney to analyse the results and provide a summary is an additional AU\$5-6,000 or even more. However, another patent attorney estimated the cost to be much less, around AU\$2,000, depending on the quality of analysis.

It should be noted that some respondents had very different views on the changing nature of patent searching requirements. One company respondent said that searching has always been a headache and is no more so now than it was 10 years ago. Indeed, some of the modern databases, particularly Derwent, have made searching considerably easier. A number of company respondents said that they subscribe to a range of databases. Others said that they have their own databases of the intellectual property of their competitors and continually add to this as new competitors become known. The more commercially focused research institutions also have procedures in place for

\footnotetext{
${ }^{298}$ Walsh, Arora and Cohen, above n28 at 294.
} 
keeping abreast of the developments in the area. One technology transfer officer said:

As well as subscribing to a number of databases for patent searching we also keep an eye on what our competitors are doing - for risk analysis. We use commercial and university databases so that we can cover the whole ground. We download patents all the time. We also have watching briefs. We expend a fair amount of our budget on these tools. It is onerous, it takes a lot of work. We are expanding our group to assist with this.

One of the problems is that researchers tend to be focussed very much on their own particular area. However, because of the breadth of some patents it is necessary to search across a broad area. One respondent commented that the titles can often be deceptive, for example, the title "improvements in electrophoresis gel" could describe a whole range of patents. The costs increase dramatically once the content of patents has to be examined. Ideally, following preliminary searches the number of patents that require detailed evaluation should be reduced as much as possible. However, a number of respondents expressed the view that the quantum of patents that require this detailed examination is in fact increasing.

\section{Number of problematic patents ${ }^{299}$}

Interestingly, although the number of patents that require detailed analysis would seem to be increasing and the cost of searching and analysis is escalating, the final number of patents that are likely to impact on a particular research project still seems to be quite small. A patent attorney commented that:

When searches are done, there will usually be less than 10 problematic patents. If there are more than 10 there is a real problem. We look at finding a niche

\footnotetext{
299 The term "problematic" was often used by our respondents to describe the patents that they saw as having the potential to impact on a particular research project. For convenience, we have adopted this terminology, and use it to describe patents that are likely to be infringed during the course of a particular research project unless action is taken to avoid infringement (for example, licensing or inventing around). Hence these problematic patents have the potential to block research (see our discussion of blocking patents in Results Chapter 4).
} 
mechanism or trying to get a licence. We need to be able to accurately define area of overlap.

Another patent attorney reported that on average there will be 20-30 patents that need to be looked at if fairly specific search terms are used. Following analysis, the number of problematic patents can often be reduced to two to three. One respondent succinctly described the situation for her company:

With regard to patent searches, when we are looking at freedom to operate we find anything from more than a dozen to 30-40 that are relevant. We analyse these. In the end there may be only one or two or a few more that are blocking.

These figures are consistent with data from other studies. For example, in the Walsh study it was reported that respondents have to consider a large number of patents initially (sometimes hundreds) but that the number of problematic patents is small, six to 12 in a complicated case, zero in others. ${ }^{300}$ Thus, they conclude that although the number of patents (and thus licences) that are relevant to a particular project has increased over the past decade, the number is still manageable. ${ }^{301}$

We do nevertheless interpret these results with some caution. We suggest that, because of the youth and lack of financial security of the Australian industry, a much lower level of encumbrance can be coped with, when compared with the better established United States industry. There would seem to be a low threshold to the number of relevant patents that will be tolerated - if there are any more the area of research may be abandoned. For example, the respondent who noted above that there may be only one or two blocking patents added that:

Anything beyond three is probably too many. It makes it very difficult if there are different parties. We need all of them to agree and we don't want to sign on for one if we can't get the others. Negotiations are becoming more difficult - there are more patents,

\footnotetext{
${ }^{300}$ Walsh, Arora and Cohen, above n28 at 294.

${ }^{301}$ Walsh, Arora and Cohen, above n28 at 295.
} 
more parties and the deals are more costly. The number of patents we have to consider has grown.

\section{SURVEY DATA ON NUMBER OF IN- LICENCES}

In each of the surveys respondents were asked if they had requested licences to use patented tools and/or materials in their research. Twelve of the research institution respondents (52 percent) and 22 of the company respondents (45 percent) reported licensing-in activity. Only three out of the 18 diagnostics respondents reported licensing-in activity for research purposes (17 percent, 23 percent of respondents conducting research). ${ }^{302}$ Participants were then asked to specify the number of licensing-in agreements. Research institution and company responses to this question are summarised in Table 14. Of the three diagnostics respondents who reported that they licensed-in, two said that they had one licence and one did not specify the number of licences.

Table 14: Numbers and types of in-licences

\begin{tabular}{|c|c|c|}
\hline Number & Research institutions (\%) & Companies (\%) \\
\hline 0 & $10(43)$ & $26(53)^{303}$ \\
\hline 1 & $5(22)$ & $5(10)^{304}$ \\
\hline $2-4$ & $5(22)$ & $9(18)$ \\
\hline $5-9$ & $0(0)$ & $2(9)$ \\
\hline $10-19$ & $0(0)$ & $0(0)$ \\
\hline $20-50$ & $1(4)$ & $1(2)$ \\
\hline Number not specified & $1(4)$ & $5(10)$ \\
\hline No answer & $1(4)$ & $1(2)$ \\
\hline
\end{tabular}

In most cases respondents said that their licensing-in agreements were entered into on a commercial-in-confidence basis (only two of the research institution respondents and four of the company respondents said that there was no commercial in confidence requirement). The majority of licensing-in agreements (around 60-70 percent) were with

\footnotetext{
${ }^{302}$ Note that licensing-in for clinical purposes is discussed in Results Chapter 6.

303 One of these stated that its parent company had licensed-in, but it had not licensed-in in its own right.

${ }^{304}$ Note that two of the company respondents who reported that they had one inlicence were from the non-biomedical sector (the other two respondents from this sector reported no in-licences).
} 
United States patent holders and around 30 percent were with Australians. Other jurisdictions included the European Union, Israel, Canada and New Zealand.

These results clearly demonstrate that the majority of our survey respondents report having to enter into small numbers of in-licences. Forty eight percent of research institution respondents and 29 percent of company respondents reported between one and four in-licences. In addition to this, around half of the respondents in each category reported that they had no licensing-in agreements whatsoever. These results, of themselves, suggest that there is no anticommons in Australia. Indeed, they suggest the opposite: that Australian research institutions and companies have broad freedom to operate in their particular areas of interest. We note further that the survey question only asked respondents to identify the total number of in-licences. We did not ask respondents to identify the number of in-licences required for individual research projects. Hence, the number of in-licences required to be entered into for a particular research project is likely to be even lower than the numbers reported in Table 14.

Although these levels of licensing-in activity would seem at first glance to be quite low, we believe that the anticommons issue needs to be explored further. We have already seen evidence of widespread collaborations between the various sectors of the biotechnology industry in Australia, and seen that these collaborative arrangements generally include provisions relating to ownership and licensing of intellectual property. ${ }^{305}$ Indeed this would appear to be the preferred method for transferring technology from the research sector to the private sector and from upstream to downstream zones of the private sector. It is not difficult to envisage how this system works in practice, using the example of drug discovery research. Initial research is carried out in the research sector funded by a biotechnology development company. A potential target is found and patented. The terms of the collaboration require that ownership vests in the company. The company then adds value with the assistance of a large multinational pharmaceutical company. Ultimately the patent is either assigned or licensed to the pharmaceutical company in exchange for up front fees and royalties.

On this basis we would not expect to see a great deal of licensing-in activity in the Australian industry sectors. However, this schema is

\footnotetext{
${ }^{305}$ In Results Chapter 2.
} 
overly simplistic because it fails to take into account the other relevant patents, particularly research tool patents, that may potentially be infringed at some stage during the research and development process. It also fails to account for the increasing number of steps in the drug development pipeline. It is to these arrangements and patents that we must look to determine whether or not there is an anticommons.

\section{NUMBER OF IN-LICENCES AND PROJECT ABANDONMENT}

The survey data on licensing-in activity presented above indicates that, aside from the direct in-licensing route from research to product, there is little evidence of other licensing-in obligations. However, these data only show the number of licences actually entered into. There may be circumstances where there is a requirement to enter into multiple licence agreements and because of this other options may also need to be considered, particularly project abandonment and inventing around. We explored this issue in our interviews.

\section{Interview data on number of in-licences per research project}

When asked about the specific number of licensing-in agreements that they were required to negotiate, some respondents said that they were unable to come up with a precise figure, because each project was different and depended on an array of factors. However, where respondents did put a figure on the number of their in-licences, this was generally relatively small. For example, one respondent said that for one project the company had to negotiate three to four licences. Another said that generally four to five licences will give you freedom to operate. Neither of these figures seems to be particularly high. In combination, this interview data and the survey data presented in Table 14 suggests that multiple in-licences are not the norm. Indeed, the norm would seem to comfortably sit at less than five. We question whether this was the order of magnitude that Heller and Eisenberg were contemplating when they posited their anticommons theory in relation to biomedicine.

Having said this, most respondents expressed the view that the number of licences that have to be negotiated is clearly an important factor in deciding whether or not a particular project should go ahead, 
and it would seem that decisions are made well before any attempts are made to enter into negotiations. In consequence, we believe that it is vitally important to acknowledge that it is possible that a number of potentially anticommons-affected projects do not come onto the radar, because such projects will have been abandoned well before any difficulty of negotiating with multiple parties is encountered. For example, one respondent reported that:

We start looking at licensing-in as we come out of the discovery process into the development phase. We always keep an eye on what others are doing. We are always looking for blocks, e.g. if a project needs say 20 licences to go ahead this may be a reason for not taking a product to development. There are various reasons for not pursuing a project, including IP, manufacturing capacity, cost. The requirement to get licences will not stop us if we have good intellectual property because we could build the cost of licences into any commercialisation deal, which would shift the costs from us. But if the costs are high or a great number of licences are needed we would have to factor this in carefully.

Another respondent said:

We generally look at the patent scene around research being undertaken by us. If it is going to be too difficult to obtain access, we don't bother with that area of research. One issue is stacking. We faced this issue in getting one of our products off the ground. Patent numbers can quickly add up, you can be dealing with a number of licensees. You may need to negotiate with a lot of people. We avoid dealing with technologies where we have to deal with more than one person or company to obtain licences. We look at around 100 projects a year, on average two a week, and ultimately choose one. There are lots of areas of research, so if access looks like it might be difficult we walk away.

Other empirical studies tend to arrive at similar figures for the number of acceptable in-licences. In the Straus study, for example, it was concluded that one to three licences per marketable product could be tolerated. However, it was pointed out that the number could reach 
seven or more and that this could endanger the commercialisation of the final product. ${ }^{306}$

\section{Redirecting research efforts, inventing around and project abandonment}

Many respondents referred to the need to redirect their research efforts in order to avoid infringing patents held by others. We have already discussed issues associated with redirecting research to avoid single blocking patents in results Chapter 4 . Here we focus on issues associated with redirecting research when a research area is encumbered with a number of patents rather than single blocking patents.

At the outset a distinction needs to be drawn here between abandonment and redirection of research efforts. Abandonment clearly has much more important consequences both at the individual level, in terms of waste of resources, and at the society level, in that potentially valuable areas of research may be overlooked, or not researched as thoroughly as they could be. We do have some evidence of respondents reporting abandonment of research projects where they considered they would be unable to obtain the necessary licences on reasonable terms. Clearly, with the increasing complexity of the patent landscape it will become increasingly difficult simply to redirect research efforts, although at present it would still seem to be relatively easy, in some areas at least.

There is no fixed rule as to the threshold number of problematic patents for project redirection or abandonment. Much depends on the nature and importance of the research. For example, one respondent described a project in which there were multiple blocking patents. Nevertheless, he explained that the company was still trying to negotiate a deal. "We don't rule this out entirely, but it needs to be an important project."

Taken together, the above comments are very relevant to the question of whether or not an anticommons exists. If projects are abandoned where, for example, more than four to five licensing-in agreements are required and if this is a common occurrence, then this suggests that an anticommons may well exist. Furthermore, some caution is required in relying on data on numbers of licensing-in agreements

\footnotetext{
${ }^{306}$ Straus, Holzapfel and Lindenmeir, above n36 at 6-7.
} 
required for freedom to operate because this data ignores abandoned projects.

Although our results suggest that many respondents will choose to redirect their research efforts to avoid heavily encumbered areas, at the same time we did perceive a general desire to find practical means to keep the stream of research and development going. In some areas the best way to achieve this may be by making patented technologies widely available by non-exclusive licensing for modest licence fees. Whilst this will not be appropriate for all technology, in some areas it will be advantageous for patent holders and licensees alike. ${ }^{307}$ Even if multiple licence fees are required to be paid, licensees will not necessarily balk at this provided that pricing is reasonable. Most see it as "just another cost of doing business."

Some of the other empirical licensing studies also briefly consider the role of MTAs and agreements relating to access to sequence databases in the establishment of an anticommons. Whilst we did not specifically raise these issues with respondents, some did comment on the number of MTAs that they were required to enter into. For example, one research institution survey respondent stated that the institution had over 30 MTAs. Some interview respondents referred to potentially restrictive terms in such agreements (discussed more fully in Results Chapter 4). In addition, it is widely known that some database access agreements have been entered into. The Australian National Health and Medical Research Council, for example, reached an agreement with Celera Genomics in 2000, allowing access to Celera's human, mouse and Drosophila databases. The agreement required participating institutions to pay an annual licence fee of AU\$6,000. ${ }^{308}$

\section{Project abandonment and research tool patents}

As Walsh, Arora and Cohen clearly point out, there is a difference between abandoning a project because another company has acquired a proprietary position in the area and abandoning it because of inability to access the inputs to the discovery process (the research tools). ${ }^{309}$ They suggested that it was relatively rare for research to be redirected to new areas because of concerns over research tool

\footnotetext{
${ }^{307}$ Issues associated with exclusive and non-exclusive licensing are discussed more fully in Results Chapter 4.

308 Reported in Today's Life Science (July/August 2000) at 6.

${ }^{309}$ Walsh, Arora and Cohen, above n28 at 298.
} 
patents. ${ }^{310}$ Similarly we found that many of the instances in which our respondents reported project abandonment or redirection fall into the former category. In fact we found few instances in which research tool patents were raised as a matter of concern. ${ }^{311}$

One comment made by a patent attorney suggests that the Australian industry should not be too complacent about this issue. She said that:

Research tool patents are more and more becoming impediments. They are becoming more frequent in Australia. Not just claims to specific sequences. They are generally owned by multinationals. At present they are generally not being enforced. The patentee has to be aware of what other people are doing in their own lab. Hence they are difficult to enforce. The problem is that you don't know that others are infringing.

Our survey results do indicate that a number of the in-licences identified by respondents are non-exclusive with United States patent holders. This suggests that there may be some licensing-in of research tools from United States-based patent holders, although the fact that these licences are confidential means that it is difficult to collect further information on the precise nature of these licences. In addition, gene patents and patent applications also exist in Australia for a number of disease genes that are tested for in Australian diagnostic facilities. The implications of enforcement of these patents against diagnostic facilities are discussed more fully in Results Chapter 6.

\section{Other reasons for redirecting research and project abandonment}

It is actually quite difficult to obtain quantitative data on the numbers of projects that are abandoned and the reasons why project abandonment occurs. It may be that this will occur because of patent thickets and perceived future negotiating difficulties (i.e. anticommons issues). However, we do acknowledge that projects will be abandoned or redirected for a whole host of reasons, and these may often be more to do with the intrinsic value and likelihood of success of the technology than the level of encumbrance. Other reasons include lack of funding and perhaps most commonly in Australia,

\footnotetext{
${ }^{310}$ Walsh, Arora and Cohen, above n28 at 303.

${ }^{311}$ See comments of interview respondents on research tool patents in Results Chapter 1.
} 
failure to find a commercial partner. The Walsh study suggests that the main reasons for not undertaking projects include technological opportunity, demand and internal resource constraints. ${ }^{312}$

We have already discussed the problems encountered by the Australian industry in this area in Results Chapter 2. Many of the reasons are similar to those stated in the Walsh study. However, one overriding concern in the Australian industry is inability to find a financial sponsor. Most participants in the Australian industry are small to medium enterprises with fairly shallow pockets. Many will require venture capital to survive and unless they can make their research projects attractive to financial backers project abandonment will occur. However, in our view this issue is intimately linked with the anticommons issue: one of the reasons why a venture capitalist will not find a project attractive is that if it is in a heavily encumbered area, multiple licences will have to be negotiated, or, if licences have already been entered into, the technology could already be weighed down with royalty and reach-through right obligations. Venture capitalists in Australia in particular are risk averse and hence the freer that a particular research project is from encumbrances the more attractive it will be.

\section{ROYALTY STACKING}

Walsh, Arora and Cohen reported that royalty stacking was unlikely to be a "significant and pervasive threat" for most ongoing research and development projects. ${ }^{313}$ Our respondents were generally much more cautious on this issue. Most said that they were aware of the potential for royalty stacking to arise and that they guarded against it. Indeed, one upstream company respondent said that this is one of the first issues that is addressed. However, it is more difficulty to define what is actually meant by royalty stacking as such. One upstream company respondent said that his company defines royalty stacking as four to five licences with royalties of 15-20 percent. However, he acknowledged that this is not that common and that generally there will only be one or two licences.

One respondent reported that the types of considerations that are taken into account in deciding whether to continue with an in-

\footnotetext{
${ }^{312}$ Walsh, Arora and Cohen, above n28 at 304.

${ }^{313}$ Walsh, Arora and Cohen, above n28 at 299.
} 
licensing deal or not include: stacking royalties, competing interests and total percentage of royalties that the other party has already committed to. However, an intermediate company respondent said that his company had not encountered licence stacking. However, he went on to acknowledge that research was not undertaken if this problem arose, which would seem to be contradictory to his previous comment.

One upstream company respondent predicted that in the future, when conducting licensing negotiations, companies may well be exposed to licence stacking and overlapping royalty structures. One respondent said that large pharmaceutical companies abhor royalty stacking. However, a pharmaceutical company respondent noted that although reach-through royalties and divided ownership don't help in the drug development process, "they are not showstoppers”.

A number of respondents commented that it is vital that intermediate companies have to keep an eye on their capacity to on-license when agreeing to royalty rates. This has to be factored into the commercialisation process and it can be a significant impost on revenue stream, because each one to two percent adds up. If an intermediate-level company has a number of obligations to pay royalties, this detracts both from their capacity to on-license and from the profits they are likely to get from further downstream licensing.

We tentatively suggest that because the difficulties that Australian companies have in entering foreign markets, particularly the United States market, they have to make their technology as attractive as possible. ${ }^{314}$ One of the important ways to do this is to reduce encumbrances as much as possible. Consequently, royalty stacking may well be more of an issue for companies here than for companies in the United States that have an established position in that market.

Added to this, Walsh, Arora and Cohen acknowledge that for start up companies and universities, stacking licence fees and royalty obligations can be prohibitive. ${ }^{315}$ Pharmaceutical companies and established biotechnology companies are much less likely to be affected. Given that much of the Australian biotechnology industry falls into the former category, again it is possible that the effect of

\footnotetext{
${ }^{314}$ On entry into foreign markets as a barrier to entry, see Ernst \& Young 2001, above $\mathrm{n} 1$ at 49 .

${ }^{315}$ Walsh, Arora and Cohen, above n28 at 301-302.
} 
multiple licences will be more acutely felt here than in the United States.

Having said this, however, Australian research institutions and companies may well be at an advantage over their United States counterparts if they can avoid having to license-in certain research tools. The fact that a number of the controversial United States research tool patents have not been granted here suggests that Australian players could have fewer royalty commitments than their United States counterparts.

\section{REACH-THROUGH RIGHTS TO FUTURE INVENTIONS}

Reach-through rights to future inventions can have the effect of deterring research and development. We have already pointed out that reach-through rights to future inventions are commonly contentious in licensing negotiations. ${ }^{316}$ A multitude of these provisions poses the risk of bargaining breakdown; as Heller and Eisenberg point out, an accumulation of reach-through licence agreements "...gives each upstream patent owner a continuing right to be present at the bargaining table as a research project moves downstream toward product development." ${ }^{317}$ Terms giving rights to future inventions may also deter parties from being interested in the technology in subsequent negotiations.

Despite this theoretical risk of accumulated reach-through rights, we did not hear complaints of them from any of our respondents. This does not mean they do not exist in practice; as there were many complaints about provisions giving reach-through rights in licences, it may well be the case that some downstream licensees are encountering stacking licences giving numerous parties rights to future inventions. It is also fair to assume given the comments from respondents, that licensees are baulking at the inclusion of such terms in licences. Most respondents who did specifically complain of stacking licences, did so however in the context of reach-through royalties.

\footnotetext{
${ }^{316}$ See Results Chapter 4.

${ }^{317}$ Heller and Eisenberg above n131 at 700.
} 


\section{SUMMARY}

In summary, our survey and interview data show that patent searching is an onerous and expensive process and there is little doubt that increasing patent activity is adding to the complexity of searching, although improved database searching facilities are providing some assistance. Despite this increased patent activity, ultimately it appears that the number of patents that are likely to impact upon a particular research project is still quite small, at least for the majority of our respondents. Similarly, the number of in-licences entered into by our respondents is also quite small, often less than five. However, in part the reason for this is that if a higher number of problematic patents is encountered this is likely to lead to project abandonment, redirection or inventing around.

Taken together, these results do not provide conclusive evidence as to the existence or absence of an anticommons in Australia. However, our results do show that industry participants constantly have to bear in mind a whole range of factors in deciding whether or not to pursue a particular project, including, at the very least:

- whether or not they are infringing intellectual property held by others;

- whether they should enter into licence negotiations;

- how many licences they should enter into for any given project;

- how much they should be prepared to pay in upfront fees, milestones and royalties, bearing in mind that it is likely that they will have to on-license their technology to bring it to market; and

- whether, taking all of these factors into consideration, the project should be proceeded with, redirected or abandoned.

These results have some resonance with other studies and with the outcomes of discussions at the OECD round table. It was noted in the OECD Report that:

In the discussion, patent thickets, royalty stacking and reach-through rights were all recognised as real 
concerns for the industry, but none were seriously judged as a threat to innovation in biotechnology. ${ }^{318}$

Despite this perceived absence of threat to the industry as a whole, the Report nevertheless highlighted the necessity of finding "working solutions" to these issues.

Our data indicates that the number of licences per project is not usually prohibitive. As previously mentioned, it is difficult to obtain definitive data on projects abandoned, but some respondents certainly reported abandoning projects if obtaining licences looked as though it would be too difficult. It seems inevitable that increasing complexity of the patent landscape will lead to the need to enter into multiple inlicences, thereby increasing the difficulties in licensing, which in turn will increase the risk of project abandonment.

Project abandonment may seem less of a problem when it occurs at the stage due diligence is done because it entails little cost to the company. But there will still be some social cost if marginal projects are not pursued - low-value transactions may still be socially worthwhile, particularly in the biomedical area where future value may be difficult to predict at the outset. Again, it is difficult to state conclusively whether this is an issue that is restricted to isolated circumstances, but there were enough respondents who reported it to conclude that it happens regularly if not frequently.

${ }^{318}$ OECD , above n60 at 60. 


\section{RESULTS CHAPTER 6: SUPPLY TO END USERS}

The primary focus of our inquiries in this study was more to do with the impact of patents on research and development than on the effect of patents on end users of patented technology. Hence, in general, we did not ask the respondents to our research institutions and company surveys or our interviewees to provide us with a significant amount of information relating to the impact of patents on the provision of drugs and devices to end users. However, some respondents did make reference to supply-related issues.

In the diagnostics area, on the other hand, we specifically sought details in the surveys relating to the impact of patents on the supply of diagnostic services. The reason for this is that the need to address this issue in the Australian context has become particularly pressing following the publication of the United States studies by Mildred Cho and Jon Merz and their colleagues indicating that a number of gene patents are having a negative effect on the availability of genetic tests. ${ }^{319}$ In addition, there is heightened concern in Australia about the possibility that the BRCA 1 patent will be enforced by Myriad Diagnostics, which would have a flow on effect on the availability of the test to consumers. The results of our inquiries are presented below.

\section{PHARMACEUTICAL S}

The important role played by patents in the development and marketing of new drugs was widely recognised by our respondents. As one pharmaceutical company respondent noted, the importance of pharmaceutical patents for the industry is that they protect against generics, the "me too" drugs: "our aim is to get novel compounds onto the market before copycats come onto the market." This respondent noted that pharmaceutical patents tend to be fairly narrowly confined to the particular product. As such, the objections raised to broad patents are probably not as relevant in this sector as in the more upstream sectors. Nevertheless, the award of a patent for a particular drug can be extremely valuable and it probably goes

\footnotetext{
${ }^{319}$ See particularly Cho and others, above n159; Merz and others, above n43.
} 
without saying that pharmaceutical patents do allow for monopoly pricing and this will inevitably affect the availability of new products to consumers. The fact that pharmaceuticals, particularly biopharmaceuticals, are likely to be at the end of a long and ever expanding stream of patent rights suggests that prices are set to increase even further to enable recovery of licence fees and royalties as well as the end producer's own research and development costs.

It is important that the disadvantage to consumers of monopoly pricing caused by the patent grant is extinguished as soon as the patent expires. This can be achieved by allowing generic manufacturers to enter the market immediately on patent expiry. There was some discussion by respondents of the provision in the Patents Act 1990 allowing an extension of time for pharmaceutical patents. Some interview respondents commented that this provision can be particularly detrimental to Australian-based generic manufacturers.

Another issue that was raised by some respondents was related to formulation patents. There would seem to be a tendency for some formulation companies to ask for high royalties for licensing of formulation patents. One respondent referred to the following example:

At one stage we approached companies that could help us develop a new technique for drug delivery. When negotiating with them they wanted five percent royalties. This seemed unrealistic to me because we had developed the product. Formulation companies are demanding very high royalties, and all have their own patents that don't infringe each other's. My view is that I would rather pay a fee for service than a royalty. Formulation companies want both. Formulation patents become an issue if a company has a delivery problem. If we can we try to avoid expensive formulations.

Some of the examples of new types of formulations mentioned by respondents include:

- $\quad$ sub cutaneous drug delivery;

- oral formulations of insulin; 
- a skin patch that protrudes into the skin causing drug absorption in about 10 minutes - needleless injection.

Respondents noted that each of these can have big advantages over traditional delivery methods. However, the high royalties demanded by some patent holders may create barriers to uptake.

\section{DEVICES}

Few issues were raised by respondents relating to the impact of patents on the supply of devices. Devices would seem to fit within the framework for development, manufacturing and supply of traditional inventions. It is less likely that availability, price and quality of devices will be affected by the availability of patents than is the case for pharmaceuticals and diagnostic tests for the following reasons:

- the regulatory requirements are less onerous than for pharmaceuticals;

- the road from discovery to commercial application is less tortuous. There would seem to be far less evidence of licence stacking;

- research and development companies may also manufacture the end product in house;

- where there are patent licences, these are primarily for the purpose of manufacture rather than for downstream development. Hence reach-through royalties and other reachthrough rights are not an issue;

- where licences are give to use devices as research tools, they tend to be non-exclusive. One respondent noted: "we need clinics etc on side so we given them as much access as possible.”

\section{DIAGNOSTICS}

As the studies by Mildred Cho and Jon Merz and their colleagues clearly demonstrate, there are serious issues relating to the extent to which patents, particularly gene patents, impact on the availability of diagnostic tests. ${ }^{320}$

${ }^{320}$ See particularly Merz and others, above n43 and Cho and others above n159. 


\section{Survey data}

Because of growing concerns about the impact of patents on the delivery of genetic test services, specific questions were asked in the surveys sent to diagnostic facilities relating to the impact of patents on the delivery of diagnostic services and additional inquiries were made by telephone in order to get a good representative sample. In total, 31 of the 52 respondents (60 percent) answered questions relating to their laboratory, the tests it performs, payment of licence fees and/or royalties, receipt of notifications from patent or licence holders, responses to notifications, and views on patents.

Respondents were first asked where their laboratory was located. The majority of respondent laboratories were in public hospitals (Table 15). In contrast, in the Cho study the participants were more evenly spread between the private and public sector. ${ }^{321}$

\section{Table 15: Location of laboratory}

\begin{tabular}{|l|c|}
\hline & Number (\%) \\
\hline Public hospital & $25(81)$ \\
\hline University & $1(3)$ \\
\hline Both public hospital/university & $1(3)$ \\
\hline Private laboratory & $3(10)$ \\
\hline Both private lab/public hospital & $1(3)$ \\
\hline
\end{tabular}

Respondents in the written survey were asked to list the tests they performed. Some responded in broad terms (eg. "neurogenetic disorders", "cancer" etc), whereas others listed all of the tests offered. Respondents in the telephone surveys were asked to broadly list the tests they offered, but were asked specifically about BRCA 1 and 2, haemochromatosis and Fragile X. Data from the written surveys indicates that all of the genetic tests referred to in the Cho study ${ }^{322}$ were performed by at least one respondent in this study, except for apolipoprotein E, which was not referred to by any respondent. Haemochromatosis was the most commonly available test, offered by at least 48 percent of respondents. Table 16 presents a summary of the compiled written and telephone survey results.

\footnotetext{
${ }^{321}$ Cho and others, above n159 at Table 1.

${ }^{322}$ See Cho and others, above n159 at Table 2, and Table 1 in Part 1 of this Report.
} 


\section{Table 16: Types of tests}

\begin{tabular}{|l|c|}
\hline Category of test & Numbers (\%) \\
\hline Various blood-related disorders & $11(35)$ \\
\hline Various neurological disorders & $11(35)$ \\
\hline Various cancers & $16(52)$ \\
\hline Various single gene disorders & $17(55)$ \\
\hline Breast cancer & $9(29)$ \\
\hline Haemochromatosis & $15(48)$ \\
\hline Fragile X & $8(26)$ \\
\hline Not specified & $1(3)$ \\
\hline
\end{tabular}

Survey respondents were also asked to specify the approximate prices charged for the genetic tests that they offered. Some provided very detailed information on the cost of each test. Others provided more general information. The results are broadly summarised in Table 17. A large number of these tests are freely available, either generally, or to patients within the state or territory, or through the MBS. Fees vary considerably between types of tests and laboratories, for example, the BRCA tests are free in some laboratories but can cost up to AU\$1,950 in others.

\section{Table 17: Cost of tests}

\begin{tabular}{|l|c|c|}
\hline & Numbers (\%) & $\begin{array}{c}\text { Fee range (where } \\
\text { applicable) }\end{array}$ \\
\hline Free & $4(13)$ & \\
\hline Free to in-state patients, fee for others & $5(16)$ & AU\$200-1,500 \\
\hline Some covered by MBS, ${ }^{323}$ fee for others & $6(19)$ & AU\$35-1,800 \\
\hline Fee based & $6(19)$ & AU\$50-1,950 \\
\hline No answer & $10(32)$ & \\
\hline
\end{tabular}

Respondents were asked whether they were required to pay licence fees or make royalty patents to any patent holder in respect of any of the tests they performed. They were then asked to specify the nature and number of licences in the following categories: genetic test; reagents; PCR; other methods; and other. They were also asked to specify the method of payment (e.g. up front licence fee, royalty, both). The results are summarised in Table 18. Eleven respondent laboratories (35 percent) reported that payments of licence fees and/or royalties were made, but almost all of these (nine out of 11) were

${ }^{323}$ As noted in Context Chapter 4, the Federal Government's position is that the MBS only covers DNA testing for Fragile X, factor V Leiden, haemochromatosis, protein $\mathrm{C}$ and $\mathrm{S}$ deficiencies and antithrombin 3 deficiency. 
royalties paid to Roche Inc for use of taq polymerase in the polymerase chain reaction (PCR).

Table 18: Payment of licence fees or royalties.

\begin{tabular}{|l|l|}
\hline \multirow{4}{*}{ Yes } & \multicolumn{1}{|c|}{ Numbers (\%) } \\
\cline { 2 - 2 } & \multicolumn{1}{|c|}{ Total: 11 (36) } \\
\cline { 2 - 2 } & PCR/taq: 9 (29) \\
\cline { 2 - 2 } & Other reagents: 1 (3) \\
\cline { 2 - 2 } & Test kit: $1(3)$ \\
\cline { 2 - 2 } & Unsure: $1(3)$ \\
\hline No & \multicolumn{2}{|c|}{ 18 (58) } \\
\hline Don't know/no answer & \multicolumn{2}{|c|}{$2(6)$} \\
\hline
\end{tabular}

Respondents were asked whether they had ever received notification from a patent holder that the testing they were performing was the subject of a patent. They were also asked to identify the patent and state their response. Only eight (26 percent) respondents stated that they had received notifications and all of these related to PCR (see Table 19). One of these respondents also commented that they had received a verbal notification concerning the haemochromatosis test, but this had not been pursued formally.

\section{Table 19: Notifications}

\begin{tabular}{|l|c|}
\hline \multirow{3}{*}{ Yes } & Numbers (\%) \\
\cline { 2 - 2 } & \multicolumn{2}{|c|}{$8(26)$} \\
\cline { 2 - 2 } & PCR/taq: $8(26)$ \\
\hline No & HFE: $1(3)$ \\
\hline
\end{tabular}

In summary, these results show that, compared with the results from the United States study, there is little indication that holders of patents related to disease genes were actively enforcing their patents against Australian genetic testing laboratories at the time that this survey was conducted. Despite this, many respondents expressed concern about the impact of gene patents on genetic testing services, as demonstrated in Table 20. Respondents were asked about the impact of patents on the development of new tests, access to tests, cost of tests and the quality of tests. This table presents a summary of responses to those questions. It should be noted that of those respondents who stated that the impact was variable, the majority highlighted gene patents as more likely to have a negative impact than other types of patents. 
Table 20: Views on the impact of patents on diagnostic tests

\begin{tabular}{|l|c|c|c|c|c|}
\hline & $\begin{array}{c}\text { Positive } \\
\mathbf{( \% )}\end{array}$ & $\begin{array}{c}\text { Negative } \\
\mathbf{( \% )}\end{array}$ & $\begin{array}{c}\text { Variable } \\
\mathbf{( \% )}\end{array}$ & $\begin{array}{c}\text { No effect } \\
\mathbf{( \% )}\end{array}$ & $\begin{array}{c}\text { No answer } \\
\mathbf{( \% )}\end{array}$ \\
\hline $\begin{array}{l}\text { Development of } \\
\text { new tests }\end{array}$ & $6(19)$ & $12(39)$ & $9(29)$ & $1(3)$ & $3(10)$ \\
\hline Access to tests & $1(3)$ & $14(45)$ & $12(39)$ & $2(6)$ & $2(6)$ \\
\hline Cost of tests & $2(6)$ & $16(52)$ & $6(19)$ & $3(10)$ & $4(13)$ \\
\hline Quality of tests & $2(6)$ & $5(16)$ & $10(32)$ & $5(16)$ & $9(29)$ \\
\hline
\end{tabular}

The results in Table 20 clearly show that there was a level concern amongst our survey respondents that patents, and particularly gene patents, could impact negatively on the provision of genetic testing services. Very few respondents saw the impact as being positive, although a higher percentage said that patents impacted positively on the development of new tests (19 percent) than on access, quality and cost (three to six percent).

In our view, these results probably reflect more widespread concern in Australia about the possibility that gene patent and licence holders might enforce their patents against testing laboratories (indeed, some respondents in this study answered "not yet" to the question of whether they had received notification letters). These survey results were collected prior to the widespread publicity surrounding the enforcement actions of GTG in relation to its junk DNA patents. Having said this, most of our data collection occurred after publicity surrounding the announcement on 28 October 2002 of a strategic alliance between Myriad and GTG involving the BRCA tests. ${ }^{324}$ This led to widespread speculation that the delivery of enforcement notices from GTG on behalf of Myriad was imminent, and doubtless affected the responses made in the surveys. However, it should be noted that GTG has never indicated that it has any plans to pursue this course of action, and in July 2003 it confirmed that it has no intention to enforce the BRCA patents on behalf of Myriad. ${ }^{325}$ Nevertheless, Myriad may still choose to enforce the BRCA patents in its own right in Australia in the future.

\footnotetext{
${ }^{324}$ GTG and Myriad above n8.

${ }^{325}$ Letter from GTG to Medical and Scientific Colleagues, 21 July 2003. Available on the Genetic Technologies website at:

http://www.gtg.com.au/Announcements.html\#21jul (accessed 30 July 2003).
} 
Aside from the BRCA patents, the Cho study clearly showed that a number of other patents are being actively enforced in that country. ${ }^{326}$ Could Australian testing laboratories face demands for licence fees from a number of different patent holders in the future? The small size of the Australian market suggests that it may not be worthwhile for foreign companies to pursue Australian laboratories. In addition, most laboratories are in public hospitals and many do not charge for their services, further suggesting that there may be little financial incentive in targeting them. Events in Canada surrounding attempts by Myriad to enforce its BRCA patents suggest that patent holders may be reluctant to be involved in litigation with public healthcare providers. Although the Ontario provincial health service chose to ignore an enforcement notice received from Myriad in 2001, Myriad does not appear to have taken any action in response. ${ }^{327}$ This lack of action by Myriad may have been the trigger that encouraged other provinces to resume testing. ${ }^{328}$ Other patent holders may also be reluctant to challenge state instrumentalities. However, it is hardly desirable for the cloud of patent infringement proceedings to hover over the delivery of healthcare services.

Arguably, a number of the common genetic tests performed in public laboratories could infringe the junk DNA patents. Potentially, their impact could be far more significant than Myriad's BRCA patents. However, it may be that an appropriate balance can be achieved between the right of GTG to enforce its patents and the need for health care providers and researchers to continue their important work. Dr. Mervyn Jacobson, the Executive Chairman of GTG has expressed his desire to work with other parties in the field - "with the ultimate objective being, to help improve the health and quality of life of the Australian community". ${ }^{329}$ However, his statement in a recent television program that GTG is already enforcing its patents against testing laboratories in Australia has doubtless caused concerns in this sector of the industry. ${ }^{330}$ We suggest that, if anything, the views expressed by survey respondents on the impact of patents on genetic

\footnotetext{
${ }^{326}$ Cho and others, above n159.

327 See, for example, Macdonald, above n5.

${ }^{328}$ British Columbia Ministry of Health Services, 'Federal Leadership Urged as Genetic Testing Resumes’. (14 February 2003) Press Release.

${ }^{329}$ M. Jacobson 'Genetic Susceptibility Testing - A Third Progress Report'. 22 May 2003. Available on the Genetic Technologies website at: http://www.gtg.com.au/Media.Coverage.html (accessed 26 June 2003).

${ }^{330}$ ABC Four Corners, above n7.
} 
tests are now even more likely to be skewed further towards the negative.

\section{Interview data}

A number of interviewees with links to genetic testing also made comments about the impact of patents in this area. One public sector researcher said that:

Gene sequence and research tool patents are not problematic in the practical sense so far. I have no particular problem with paying a royalty to a legitimate inventor. It's just another cost of doing research. Just by purchasing taq polymerase we pay royalties to a licensed supplier. However, where patented tools/tests are not available for licence this is not in the community's interest.

Other respondents confirmed that in general people are not enforcing their patents in the genetic testing/research area but also recognised it could become a problem in future. Most respondents were well aware of the taq polymerase patent owned by Roche and had either themselves been approached by Roche or Cetus (its predecessor in title) for licence fees, or knew of others who had been approached. For example, one respondent said that:

Roche didn't approach me directly about their PCR patent but did approach some hospitals in the state. The lawyer representing Roche was asking for a seven percent royalty. We said that the tests cost nothing. They said that it should be seven percent of the market value. This was very confusing. The Health Department took over negotiations over royalties. Roche said that other states had signed up, but because of commercial in confidence they wouldn't disclose anything about this. We didn't know whether they had or had not signed up. This is the only time that we have been approached to licence in.

Some of the respondents involved in research or clinical testing in this area admitted that they were only generally aware of intellectual property owned by others, largely because of lack of resources to dig through patent data to see if they are infringing someone else's 
intellectual property. Some expressed the view that it was not necessary to make detailed inquiries because of an understanding "(perhaps mistakenly) that for non-commercial research we don't need a licence.”

Respondents generally stated that they would be prepared to pay reasonable royalties for test kits, taq polymerase, and so on, and viewed this as just another cost to be built into doing tests. At the same time, concern was expressed about a requirement for licence fees to be paid when a diagnostic facility develops its own tests and uses its own taq polymerase. Even more concern was expressed about any requirement for work to be done at the patent holder's laboratory at commercial rates. As one respondent put it: "this is bad commercially and in terms of quality of science... as well as interaction between the referring physician and the testing laboratory". Another put it more succinctly: "there is a difference between paying a reasonable royalty and being held to ransom.”

Concern was also expressed that control could be lost if testing is taken outside the hospital environment. One respondent noted that testing is only done if it is indicated, and a tight hold is kept on who can have it done and appropriate counselling is ensured. This could be lost if testing was undertaken outside the public hospital system. However, it was noted that this is not meant to suggest that a private facility will not offer a good service but only that it is more difficult to monitor.

\section{SUMMARY}

These results show that those respondents in Australian diagnostic facilities that we surveyed and interviewed have not yet been subjected to the same sort of patent enforcement actions that have been reported in the United States. However, there are serious concerns in this sector of the industry that it is only a matter of time before such actions are taken. In part, the responses of survey respondents were no doubt influenced by the announcement of an alliance between Myriad and GTG and the media hype surrounding it. However, this does not mean that these concerns are totally without foundation. Whilst it is likely that few respondents in the industry would object to the payment of reasonable royalties on test kits and other reagents, there is more concern abut the prospect of having to enter into licensing arrangements, particularly if the licence terms 
limit the independence of facilities to carry out their own testing. A requirement that the patent holder or their licensee conducts all testing is likely to be vigorously (and, possibly, justifiably) opposed.

In being granted gene patents, patent holders are entitled to enforce their patents against others, and have the right to chose whether or not to license others to use the patent, to determine the conditions of licence, and even, if they so chose, to ignore infringing actions. ${ }^{331}$ In this regard, patents relating to genetic tests are no different from drugrelated patents. However, there are justifiable reasons why people perceive the two to be distinct, not the least of which is the time, effort and money involved in bringing a drug to market. Each of these factors is likely to be orders of magnitude greater than for bringing a diagnostic test to market. Hence, it could be argued that the need for the patent incentive is less for diagnostic tests than for drugs. There are further important distinctions between drugs and diagnostic tests from the perspective of consumer access. Drug patents tend to be specific to individual drugs, and other alternative drug therapies may be available. Gene patents, on the other hand, have the potential to cover all diagnostic tests for a particular genetic disease. Therefore restricted access could be much more of a problem in the diagnostics area than in the drugs area. Access and cost problems are exacerbated by the fact that the PBS covers a large number of drugs, whereas the MBS only covers five genetic tests.

Another distinction between drugs and diagnostic tests relates to quality. There are extensive regulatory hurdles that new drugs have to pass through before they enter the market. This is not so much the case for new diagnostic tests. This may not be a problem provided that there is an open market, because consumers (or their service providers) will be able to select the highest quality test from the marketplace. However, if the market is closed as a result of restrictive licensing, quality could become an important issue. This issue is particularly likely to arise when, for example, there is geographic variation in a particular gene-related disease trait. Interestingly, despite this, our survey respondents tended to be less concerned about the impact of patents on the quality of genetic tests than on other aspects of testing, as shown in Table $20 .{ }^{332}$ This may be because people have not fully thought through the implications of patenting in this area. On the other hand, it may reflect a genuine viewpoint that

\footnotetext{
${ }^{331}$ Subject, of course, to any limitations imposed by law.

${ }^{332}$ It should also be noted that Mildred Cho and her colleagues obtained similar results. See Cho and others, above n159 at 7.
} 
the patent incentive is likely to improve the quality of tests or that patenting has no effect one way or the other on the quality of tests. ${ }^{333}$

Whilst patent holders are entitled to enforce their patents, this should not be at the cost of reduced availability and quality of tests and ensuring that appropriate counselling is tied in with testing. Relevantly, the recently completed final Report of the ALRC and Australian Health Ethics Committee's inquiry on the protection of human genetic information included a number of recommendations relating to genetic testing. ${ }^{334}$ For example, Recommendation 11-1 proposed that access to genetic testing for health care purposes should be better regulated; laboratories should be accredited for any genetic test conducted for medical, diagnostic or treatment purposes and should be required to comply with relevant accreditation standards. The Report also emphasised the need for ongoing development of ethical standards, particularly in relation to consent and counselling (Recommendations 11-2, 11-3 and 11-4). If these recommendations are adopted and implemented then some of the concerns expressed above relating to testing in private facilities will be alleviated. However, the potential for increased test costs resulting from the payment of licence fees and royalties is likely to be a matter of ongoing concern and debate. ${ }^{335}$

\footnotetext{
${ }^{333}$ For a practitioner's perspective on these and related issues see D.G.B. Leonard, 'Medical Practice and Gene Patents: a Personal Perspective' (2002) 77 Academic Medicine 1388. See also Cho and others, above n159.

${ }^{334}$ Australian Law Reform Commission Report No 96: Essentially Yours: the Protection of Human Genetic Information in Australia (2003).

${ }^{335}$ One concern that needs to be addressed is whether or not a condition of accreditation may be non-infringement of patent rights (John Walsh personal communication 28 November 2003).
} 


\section{RESULTS CHAPTER 7: MARKET SOLUTIONS}

The results presented in the previous six chapters paint a picture of an industry that is in the early stage of commercial development. There is a well-established tradition of high quality basic research in Australian research institutions. These institutions are discovering the importance of capturing the commercial value of their research and transferring their technology to the commercial sector. The commercial sector itself is spread across the whole gamut from upstream research to downstream product development. However, the product development sector is quite small. The final stages of drug development, in particular, are routinely carried out overseas rather than in Australia. One of the greatest challenges for the Australian industry is ensuring that research and development effort at one level is taken through to the next level in the continuum through to manufacture of end products.

The importance of protecting inventions by patents in order to facilitate technology transfer is widely recognised across all sectors of the industry. The importance of ensuring freedom to operate and avoiding encumbrances on patent rights is similarly widely recognised. The industry is facing increasing costs in dealing with both of these requirements. However, in practical terms, there still appear to be somewhat of a laissez faire attitude taken both with respect to the enforcement of patent rights and with respect to dealing with patent rights held by others. In our view, this attitude may not be sustainable if the industry is to become the economic powerhouse that the governments of Australia hope for. It is likely that this will only be achieved if patents are properly managed and exploited and if due regard is taken of all of the relevant patents held by others.

In this chapter of the Report we consider some of the practical means that the industry has found to deal with these issues.

\section{COLLABORATIONS AND LICENSING}

Perhaps the most obvious way to deal with patents that have the potential to restrict or prevent research and development is to enter into a licence agreement or some other collaborative arrangement. 
Indeed, much of this Report has focused on the way that the industry utilises these options.

Although there is significant licensing activity within the Australian industry, it may be that at the present time, licensing is less widespread than it is in other jurisdictions. Other studies have found that licensing activity within the industry is extremely liberal. ${ }^{336}$ Walsh, Arora and Cohen, in particular, said that their respondents indicated that it is typically not that difficult to contract. $^{337}$ Many broadly applicable foundational patents are licensed non-exclusively, and there is a trend toward realising value from patents by licensing widely. $^{338}$ Our data indicates that approximately half of our respondents were involved in licensing activity; most respondents who own patents reported licensing them out, and many respondents reported being able to licence-in technology to which they required access. ${ }^{339}$ Although we do not have actual figures from other studies by way of comparison, these studies give the impression of prolific licensing activity. The youth of the Australian industry may account for licensing figures being slightly low relative to other jurisdictions. Our interview respondents assured us that the Australian market is very active in terms of licensing, and licensing is an important part of the business strategy of many intermediate Australian companies who seek to add value to technology they have licensed-in, before licensing it on. One respondent stated that in terms of the intellectual property of these companies,

for most, the main value is a licence. Few [Australian companies] are big enough to extract value in their own right...Generation and licensing of intellectual property is the new paradigm in which we all have to live.

Licence agreements with international companies and institutions are very important to the Australian industry, and indeed to the

\footnotetext{
${ }^{336}$ Walsh, Arora and Cohen, above n28 at 322-3; Straus, Holzapfel and Lindenmeir, above n36 at 6-7.

${ }^{337}$ Walsh, Arora and Cohen, above n28 at 322.

${ }^{338}$ Walsh, Arora and Cohen, above n28 at 323.

${ }^{339}$ See Results Chapter 2 dealing with licensing-out of technology, and Results Chapter 5 which discusses licensing-in figures obtained during the course of this study. Note also that in their 1999 report, Ernst \& Young found that half of the companies they surveyed were involved in licensing activity; Ernst \& Young 1999, above $\mathrm{n} 1$ at 35 .
} 
international industry as a whole. ${ }^{340}$ As one respondent commented, there are hundreds to thousands of intellectual property deals per month within the global industry. However, licence deals are not always straightforward, and some difficulties in contracting effectively have been encountered by our respondents. In conducting negotiations for licensing deals, we heard many comments about problems encountered when it comes to arguing over licence details. The views of a number of respondents are encapsulated in the following statement offered by a senior member of a technology transfer company:

Getting a licence is not an easy process. You need to get an insight into who you are dealing with: their cash position, whether they are about to be sued etc. We get rumours about particular companies. Usually the outcome is a licence with an upfront and royalty component, skewed depending on who you are dealing with. Deal precedent is also important. Certain types of transactions have certain familiar aspects.

This may be a product of inequality in bargaining power and levels of experience between our respondents, and parties in jurisdictions where the industry is more established.

Widespread collaborative activity was also reported, and in many ways this represented an important method of gaining access to technologies or products, which were necessary to enable research to proceed. $^{341}$

\section{Cross-licensing}

A cross-licensing arrangement is one where two or more parties enter into a reciprocal licensing arrangement to license each other's patents. In a simple cross-licensing scenario, one patent generally represents an improvement over an earlier patent. A cross-licence is the typical response to a blocking patents situation ${ }^{342}$ and by licensing the earlier patent, the holder of the improvement patent is able to practice the improvement. Similarly, the holder of the earlier patent can practice the improvement patent.

\footnotetext{
340 See also Nicol and Nielsen above n4 at 354-358.

${ }^{341}$ See Results Chapter 2 dealing with technology transfer.

${ }^{342}$ See further Results Chapter 4.
} 
Ten respondents to the company survey had been involved in crosslicensing arrangements (20 percent). ${ }^{343}$ All but one of these would appear to have entered into cross-licences with just one other party, although four respondents indicated that they had at least two crosslicensing arrangements. Large-scale cross-licences and patent pools were not evident. Cross-licences for varying types of technology had been exchanged, and were entered into in four cases to avoid liability for infringement. From the information provided by respondents, it was difficult to ascertain the industry sectors over which crosslicensing arrangements extended.

Several of our interview respondents from both companies and research institutions, reported being involved in cross-licensing arrangements, and this figure is low relative even to the survey results. However, it was the view of a number of other respondents that cross-licensing arrangements would become increasingly important. For example, one respondent said that:

In future in conducting licensing negotiations companies will be faced with a huge web of licensing and cross-licensing arrangements.

In many cases, cross-licences are entered into as part of a collaborative relationship. They enable parties to continue research and to practice improvements that a particular party may have developed. On the other hand, one respondent thought that crosslicensing arrangements usually arise due to conflict. It seemed to be generally accepted among those respondents who had cross-licensed that cross-licensing represents an effective way of overcoming blocking patents, and similarly that cross-licensing is likely to become more prevalent as the patent landscape becomes more complex. $^{344}$

\section{INVENTING AROUND}

In ensuring freedom to operate, many respondents confirmed the need to make an evaluation of patents they need to access, and patents they need to work around. One of the respondents we interviewed who

\footnotetext{
${ }^{343}$ Note that one of these respondents was involved in plant and animal research.

${ }^{344}$ Cf Straus, Holzapfel and Lindenmeir, above n35 at 7.
} 
was involved in downstream development activities, stated that reasonably skilled people can negotiate a way in where there are impediments, or find ways around them. Inventing around problematic patents was reported to be an important strategy employed by researchers in all sectors of the industry. It has also been suggested that the ability of researchers to invent around may prompt licensing on reasonable terms. ${ }^{345}$ Several respondents disagreed that inventing around is a commonly employed tactic for avoiding infringement. One respondent whose company is involved in upstream research concerning specific mutations on particular genes thought that you would need to know a lot about a patent before you could successfully invent around it. Another whose company is involved in downstream research considered that inventing around is 'treading on thin ice', although this respondent acknowledged that they look at relevant patents in the area every day so that they are aware of what others in the area are doing.

However, about two thirds of all respondents we interviewed who were engaged in research stated that they frequently invented around patents. One respondent estimated that researchers probably spend 50 percent of their time inventing around, while another considered that researchers in his company spend around 90 percent of their time working out how to get around patents held by competitors. It is clear that the ability of researchers to invent around will depend on the field of research involved, specifically:

- how encumbered the area of research is;

- the breadth of the relevant patent(s); and

- the nature of the patented product or technology.

\section{Level of encumbrance}

Some areas are more heavily patented than others are. One respondent commented that it may be getting harder to invent around within the biotechnology industry because of the increasing number of patents. It would appear that one of the most heavily encumbered areas is stem cell research, and yet respondents still reported working around those areas covered by competitor patents. This is probably a factor that will become more relevant as the patent landscape within the industry becomes more cluttered.

\footnotetext{
${ }^{345}$ Walsh, Arora and Cohen, above n28.
} 


\section{Patent breadth}

Inventing around is easier in some areas than others because the patents are narrower and thus more susceptible to inventing around. Patent requirements have tightened up in the United States so patents are narrower and therefore easier to invent around. ${ }^{346}$ Some of the earlier patents were considered to be a real problem. One respondent pointed out that patent attorneys are trying to draft claims more broadly to prevent inventing around. ${ }^{347}$ Also, one respondent acknowledged that they tried to patent very broadly, filing as many patents as they could on a compound to prevent inventing around. This assisted them in avoiding a blocking patents situation in that it secured an area of research.

\section{The technology or product}

Some types of technology or product are easy to invent around, while others are more difficult. One respondent from an upstream company made the following comment:

Gene sequences are a special case. Most of the method patents have competing methods for almost anything: microarrays etc. There are half a dozen guys trying to push the processes and if anyone tries to corner the market it will go somewhere else. It was thought that patenting genes, SNPs would corner the market. But now look at gene expression, messenger RNA expression, which are not captured by the patents, interference RNA, etc. these are all competing technologies. It is such a creative process, I have no concerns that anything could block for very long. In the end others will find ways around the things that people are trying to block. Next year is not even relevant. People do sometimes try to block but in every case they have failed.

At the furthest downstream end of the drug development pipeline, a respondent from a small pharmaceutical company noted that they considered that there were few patents in the pharmaceutical industry

\footnotetext{
${ }^{346}$ With the exception of device patents where it was considered by one respondent that the United States standard of examination was quite poor, and resultant patents were difficult to get around.

${ }^{347}$ See the discussion on blocking patents in Results Chapter 4.
} 
that could not be invented around. As one respondent from an intermediate company noted, it is often possible to get around patents held by others by "...moving down the synthetic pathway, changing processes, or inventing around.” Again, patent claims in some areas are necessarily narrower than in other areas. For example, narrow process patents may be easy to get around, while promoters are one kind of technology that some respondents considered to be impossible to invent around. Respondents in some areas commented that they could "get around anything", while others made more qualified statements.

Although inventing around may be possible, will it result in all lost opportunities being recovered? Other studies have suggested that a single patent (or even group of patents) is unlikely to entirely inhibit research in a particular area. This is because, for example, a patent over a single protein is unlikely to prevent research into a particular disease given that many diseases are complex and there are often “...multiple approaches to the metabolic pathways."348 This is borne out by our interview data that makes it clear that few researchers or companies are having to cease research entirely, although there may be some social cost associated with research being redirected to avoid infringement. This will depend again on the technology in question. There is likely to be little social cost in the simple case of a researcher inventing around to avoid infringing a competitor's patents. Indeed, society is more likely to benefit in such a scenario. There may however, be some social cost where, for example, a patent over technology that is useful for research into the development of different but competing products is enforced. In many instances our data did not allow us to make this distinction, although it appeared that some cases at least fell into the latter category.

\section{PATENT ENFORCEMENT}

Another strategy for dealing with problematic patents is simply to ignore them. However, this strategy carries with it the risk that enforcement action will ensue. Most respondents reported that they have procedures in place to monitor infringing activities. However, the general view expressed by a number of respondents was that there is a great deal of infringement going on that is very difficult to track, and even when it is tracked, enforcement can be difficult because of

${ }^{348}$ Walsh, Arora and Cohen, above n28 at 42. 
the cost of litigation and the risk that a counter claim will be made for revocation. Some infringement may be unintentional, and may arise for a whole host of reasons, including:

- lack of adequate provision for patent searching;

- difficulty in determining the scope of a particular patent and what amounts to infringement;

- the fact that when the patent alleged to be infringed is in a different field it would not necessarily come to light with usual search terms; and

- lack of certainty about exemption for research work (see the discussion on the research exemption below);

A number of respondents reported that they believed that some people would continue to pursue particular projects even when they knew that this work may be infringing a patent. In some instances, the reason given was a belief that the patent was invalid and that the breadth of claims was not warranted by the contribution made to the field by the invention. In other cases, it seems that some companies may simply not bother to search the prior art, and only tackle the issue of patent infringement when it becomes a problem. One respondent referred to this as a "cavalier approach of some commercial parties". On the other side of the coin, a number of research institution respondents reported that, because governments tend to take risk averse strategies, projects would be dropped completely if there was any risk of infringement. Furthermore, it seems that it is unlikely that research institution patent holders would actively pursue infringers. A number of respondents said that they would leave it to commercial partners to take such actions.

\section{Detecting infringement}

A number of respondents commented on the difficulties that they encounter in detecting infringement. Most company respondents have procedures in place for tracking infringement, including searches of scientific publications, patents, etc. For example, one respondent said:

I spend hours every day on detecting infringement. The process is not black and white. I scan all sorts of stuff: web, magazines etc. Looking for activities in a couple of categories that use our technology. If there is the merest hint I collect the name. If it comes up again I start to dig. Then I do detailed digging and try to get 
as strong evidence as I can that they are infringing. Seldom do they use the exact words of the patent. It requires a degree of interpretation. I don't start writing letters until I am pretty confident that what they are doing falls within the scope of the patent.

Another said that his company has set up a sophisticated system for detecting infringement including a database of actual and potential competitors ranked in order of likelihood of infringing. Despite having these procedures in place it was recognised that detecting infringement is still difficult, particularly with regard to universities and private companies. However, one respondent did express some confidence in being able to track infringement.

\section{Pursuing infringers}

Even if infringement is detected or suspected, the alleged infringer will not necessarily be pursued. For example, one upstream company respondent noted that:

Until you get a fair way in, a lot of companies are not fussed that you are infringing and would not pursue you. There are a lot of infringers nibbling around the edges of markets that patent holders are not aware of. They may chase, they may not. Quite openly, a lot of patents are being infringed, particularly in the drug industry. In Australia there is a fear in infringing because of the limited amount of capital most biotech companies have - a large US company would attack them and they would be unable to defend such an action.

Another said that the question is how much money you have in the bank. It seems unlikely that start up companies would have the resources to chase infringers. One respondent stated that the best tactic in such circumstances is to lodge a claim in court then get the public relations machine going to move negotiations along. The situation is particularly difficult for research institution patent holders. One respondent in this area said:

We do nothing about infringement, leaving it up to our commercial partners. We have few resources. Even if 
our intellectual property was infringed, we might write a letter but we couldn't take legal action.

One respondent was strongly critical of participants in the Australian industry who do not protect their intellectual property. He put it quite simply "if you haven't got the finances to protect your intellectual property you shouldn't be in the business". He estimated that to be serious about intellectual property an annual budget of AU\$1 million is required, without getting to the cost of infringements and oppositions. A public company respondent supported this type of viewpoint, stating that she considered that pursuit of infringers was part of the company's responsibility to its shareholders. She said:

If we suffer damage we would vigorously pursue infringers. We would also pursue if we had granted rights to a partner. So, we vigorously pursue infringement where there is the prospect of damage to the company and collaborators and with respect other people’s IP. We don't run around infringing other’s IP.

If a patent holder is able to persuade others that they are engaging in infringing activities the outcome can be quite lucrative. One respondent gave the example of a company that had a piece of intellectual property that they were not exploiting at the time. They discovered that a company in Europe was infringing the patent and were able to persuade them to pay royalties. A few weeks later a United States company contacted them asking to negotiate a licence.

Given that patent searching and tracking infringement both impose onerous obligations on industry participants, we will explore some of the ways that these obligations could be reduced in the last part of this report. In particular we consider whether international discussions relating to the use of patent clearing houses are relevant in Australia.

\section{Being pursued}

We obtained very little evidence of industry participants actually being pursued for patent infringement. As discussed above, in part this is because there would seem to be a practice-based research exemption operating in the research sector. The majority of research institution respondents confirmed that they had never been pursued for patent infringement. Some company respondents also said that they were not aware of any infringement notices being issued against 
them. A patent attorney confirmed that her clients are not getting cease and desist letters at present.

The diagnostics industry sector would seem to be most concerned with the prospect of receiving cease and desist letters. This sector has received demands in the past relating to the taq polymerase patent. In addition, respondents in this sector were well aware of the enforcement actions by Myriad in other countries concerning the BRCA 1 patents. Nevertheless, aside from the tap polymerase demands there was little or no evidence that respondents were being pursued for infringement. However, one respondent noted that he was aware of enforcement action by GTG in New Zealand concerning its junk DNA patents. This action will clearly be a matter of growing concern across the industry. Indeed, one research institution participant commented that "everything we do every day infringes them.”

\section{RESEARCH EXEMPTION}

There is a significant risk that companies may face enforcement action if they infringe patents, either intentionally or innocently. In this section we consider whether research institutions face the same risk, or whether they are more unlikely to face such enforcement actions.

The data presented in Results Chapter 3 indicates that research institutions are putting in place good strategies for managing their own patents. Furthermore, they are actively involved in transferring their technology to industry, both through collaborations and, to a lesser extent, through licensing. At the same time, however, licensingin activity within the research sector is relatively low. To a large extent, this was justified by research institution respondents on the basis that their research is exempt from patent infringement. Indeed, some respondents put forward the argument that all research as such is exempt, whether it is conducted in research institutions or private sector. However, if this were the case it would be difficult to see how research tool patents could ever be enforced, and yet there is clear evidence that this does happen and that if managed properly these patents can bring in substantial licence fees. Hence, arguments that research per se is exempt appear fallacious. 
As we discussed in Context Chapter 3, the legal status of any form of research exemption in Australia is by no means clear. Use of the word "exploitation" to describe the rights of patent holders in section 13 of the Patents Act 1990 (Cth) certainly has a commercial air to it and hence there may be a good argument that basic research is exempt. The recognition in United States case law of an experimental use exemption supports this conclusion. However, the growing commercialisation of public sector research suggests that it may be difficult to rely on a blanket exemption for all research conducted in the public sector. The recent case of Madey $v$ Duke University ${ }^{349}$ in the United States illustrates the risks involved in relying on this exemption. The question of how to distinguish between basic research, which may be exempt, and commercial research, which is not, is by no means easy to answer. We look here at the practical aspects of the question: how in practice is the distinction made? In the last part of this Report we look at the question from the legal perspective: does the law recognise any distinction between commercial and non-commercial research and if not, should it?

\section{A practice-based research exemption?}

From the practical perspective, a number of interview respondents commented on the difficulties involved in determining when and where an exemption from patent infringement might apply. For example, one patent attorney acknowledged that the research exemption is very cloudy and that it is very hard to tell whether there is a commercial taint to research. A technology transfer officer confirmed the difficulties encountered in determining whether or not a particular research project can safely be pursued. She noted that if the project is pure research it is seen as being safe, but there are problems when, for example, a commercial partner has an option to commercialise the research results, because this has never been tested. It would seem that in a number of situations decisions about risks of infringement are not dealt with by the research partner to a collaboration, but are left to the commercial partner to deal with.

\section{Views of company respondents on a practice-based exemption}

A significant number of company respondents said that they would not seek licences from participants in the research institution sector because it was not a wise decision from a business perspective. For

\footnotetext{
${ }^{349}$ Madey, above n87.
} 
example, one pharmaceutical company respondent explained that even though intellectual property is the company's life blood there is recognition of the benefits to be derived from encouraging research in the areas that the company has an interest in. This respondent stated that his company would provide research materials to researchers in research institutions and that the starting premise is supply rather than denial. However, he added that if the research becomes commercially valuable the researcher has to come back to the company to renegotiate.

Another respondent said that it would be ridiculous to contemplate chasing universities for infringement. He explained that in part this was because it would affect the company's reputation in the academic community and in part because damages would not be recovered in any event. Another respondent said "it would be crazy to sue a public sector researcher: a man of straw and PR wise it's a loser”. Other company respondents supported this view, stating that it was far better to come to some sort of collaborative arrangement. However, one respondent did sound a note of caution, commenting that in some situations they may be obliged by a collaborator to pursue a university infringer. In such circumstances it seems likely that attempts would be made to negotiate a licence first and that slapping a writ on the researcher would not be a first option. One respondent said that the only time that his company would think about pursuing a university is if there is use of a key research tool.

Some respondents said that it would be unlikely that they would pursue infringement at the research level irrespective of whether this is carried out in the public or private sector. The reason given was that it may be necessary to infringe a patent in order to determine whether a particular line of research is worth pursuing. One respondent said that because of this his company would not pursue infringement at the research level, and that, on the other side of the coin, his company probably infringes to some extent in the development of its inventions. In his view, it is only when the research gets to the commercial stage that patents should be enforced.

\section{Views of research institution respondents on a practice-based exemption}

Research institution respondents generally confirmed that at present it seems that it is a rare thing for a patent to be enforced against them. One said: 
Patents held by others are never a problem. I have never had an infringement letter, except one years ago relating to taq polymerase. We were making it. Roche wrote a letter to us. We wrote back saying that we were not infringing and would not pay anyway. That was the end of it.

As such, at the present time there seems to be a general practice based research exemption operating in Australia, even though the law is not clear. Quite how long this situation will continue remains to be seen.

\section{Changing views}

There can be little doubt that patent holders have the right to enforce their patent rights against research institutions in some situations. Although there is little evidence of this occurring in practice, it appears that some patent holders are now prepared to take this step. In part this is justified by the increasing commercial focus and patent activity within research institutions. For example one upstream company respondent stated that his company was prepared to enforce its patents at the meeting of research world and commercial world. He noted that in doing so, the company could rely on the Madey $v$ Duke definition of non-infringing research, but the company takes a more generous view than this. He said that a commercial licence would be required where there is a commercial arm transaction underlying the research. A number of examples were given of types of research that the company would consider fall into this category:

- if there is a fee for service;

- if an invoice is raised and there is a revenue stream;

- if the purpose of the research is for generating intellectual property;

- if the research is done on a matter that clearly intends to lead to commercial outcome.

This respondent also said that his company does not grant carte blanche immunity to hospitals and universities but splits licences between commercial and non-commercial.

Another respondent confirmed that the Madey case shows that there are no such things as not-for-profit institutes because they are businesses which have as one of their purposes generation of funds. 
This respondent concluded that for a university to say that it can use intellectual property without recognising it as a commercial asset is problematic. He added that universities are driven to commercialise and they have a clear commercial goal. In his view, therefore, universities need to be more up front about this and acknowledge that they are chasing commercial goals.

A licensing consultant confirmed that companies are prepared to pursue institutions. He cited one example where a licence was demanded and:

[t]he university did a cost benefit analysis and decided that it could continue research to produce papers etc. But the cost is AU\$100,000 in defending an infringement action. Companies can be ruthless.

Because of these difficulties and uncertainties involved in drawing the line between basic and commercial research, a number of technology transfer personnel stated that ideally freedom to operate should be confirmed from the outset. There does seem to be a great deal of sense in this proposition. However, it has to be balanced against the high costs involved in undertaking patent searches and, where necessary, negotiating licences (discussed in Results Chapters 4 and 5).

\section{CHALLENGES TO VALIDITY}

Another option that is available when faced with problematic patents is to attempt to have them invalidated, either through opposition or revocation procedures available under the Patents Act 1990 (Cth).

Although a number of respondents said that they encounter patents that they believe are invalid, very few would actually take the step of challenging them in court. One respondent said that they would drop the compound instead. However, one research institution respondent said that the organisation would challenge a patent if necessary. He gave the example of a case where the owner wanted reach-through rights, ferocious royalties and up fronts. Having said this, it seems that such challenges in the biotechnology area are extremely unlikely to be pursued in court. The lack of case law on biotechnology patent validity is testimony to this. Nevertheless, the threat of instituting 
revocation proceedings is likely to be a powerful bargaining tool in licence negotiations.

\section{Patent opposition}

There is more case law on opposition to biotechnology patents, with a number of reported decisions of the Commissioner of Patents or his delegate. However, appeals to the Federal Court are still rare.

There seems to be some quite marked divergence of views relating to the value of opposing patents. A patent attorney stated that his clients do tend to file oppositions to competitors patents. An upstream company respondent also said that his company would file oppositions if the claims go beyond the invention and threaten the company's core intellectual property. He said that the company simply could not afford to allow any claims to go through that threaten its business. However, an intellectual property manager in an intermediate level company stated:

My position is that in some ways it is better to hold fire. Opposing claims doesn't get you very far. In fact it helps the patentee to refine their claims. As a tactic it is not good to spend money on it. It is better to build up your position in case an injunction is taken out against you [for post grant infringement]. We would be willing to enter into licensing negotiations in these circumstances.

Similarly an intellectual property advisor noted:

I have seen very little, if any, examples of oppositions. It is a cost issue: it is very expensive and difficult to identify where the benefit is.

On the other hand, a technology transfer respondent intimated that oppositions could be powerful tactical tools. She said that they can kill a project quickly because public institutions lack the AU\$100,000 or so needed to defend them. In her view this is also an issue for small companies, particularly start-ups. Bigger companies could use oppositions tactically to close down areas of research.

One respondent estimated that the cost of oppositions in Australia could be from AU\$20,000 to several hundred thousand. In Europe if 
there is an appeal the costs are likely to be in the hundreds of thousands. The United States has no opposition system. However it does have interferences and the cost of a standard United States interference is US\$300-400,000. Pursuing an infringer in the United States is easily up to $\$ 1$ million. ${ }^{350}$ This respondent noted that opposition is plan B and that his organisation looks at the possibility of licensing beforehand and may take a licence even though it is believed that the claims are invalid. However, if there is some certainty that the patent is not valid it is less likely that negotiations will be entered into. One of the problems with entering negotiations is that it gives some acknowledgement to the fact that a licence is needed.

\section{SUMMARY}

These results suggest that the market has the capacity to overcome many issues raised by intellectual property impediments. Participants in the industry recognise that intellectual property is an important asset, and value their own intellectual property and intellectual property owned by others. They have a healthy respect for this latter category, and take measures to ensure they have freedom to operate.

In many cases, licence negotiations between patent holders and users allow research to proceed and new products to be developed. This is exactly how a well functioning patent system should operate. However, as previously noted, negotiating difficulties, restrictive licence terms, refusals to license, stacking royalties and so on all can act as impediments to a well functioning market. There are doubtless cases where unhindered research and development is impossible.

In any well functioning patent regime a fine balance exists between protecting the rights of owners and the rights of users. Whilst the Australian patent system would appear to be assisting the medical

\footnotetext{
${ }^{350}$ It should be noted that the primary recommendation in an inquiry by the United States Federal Trade Commission into competition and patent law and policy was that a new administrative procedure should be enacted to provide for an administrative procedure for post-grant review and opposition to patents. Federal Trade Commission, To Promote Innovation: The Proper Balance of Competition and Patent Law and Policy (Washington: US Government Printing Service; 2003) available at: http://xml.coverpages.org/ni2003-11-11-1.html (accessed 9 December 2003) (hereafter Federal Trade Commission).
} 
biotechnology industry in achieving a reasonable level of success, an investigation of possible institutional measures aimed at promoting the development of the industry is nonetheless warranted. This is the subject of the next part of this Report. 
Results Chapter 7 


\section{PART 3: OUTCOMES OF THIS STUDY: THE WAY FORWARD}


228 


\section{OUTCOMES CHAPTER 1: THE LEGAL LANDSCAPE AND OPTIONS FOR REFORM}

Our results have shown that in some instances the Australian biotechnology industry takes a fairly relaxed attitude to both enforcing its own patents and ensuring that it does not infringe the patent rights of others. Some Australian industry participants take a fairly aggressive attitude towards protecting their patent rights, but this is not common. The lack of aggression was heavily criticised by some respondents. For example, one upstream company respondent said that:

Our major capital asset is intellectual property, but we take a loose approach to it, operating on a mate's basis. This is a good way to kill the industry. We need to use intellectual property strategically. It is not just a collection of inventions. The key is stopping others, not enabling them. Australia does not seem to have a good understanding of this in companies or research groups. Yet this is the starting point for the development of the biotech industry.

It is likely that patents will be more aggressively enforced in Australia in the future and this may well change the relaxed attitude of some participants in the industry to such matters as:

- keeping their patent rights clean and free from encumbrances;

- monitoring the use by others of their own intellectual property;

- maximising exploitation of their own patent rights both through self-exploitation and through transferring technology;

- avoiding enforcement actions by other patent holders; and

- obtaining clear authorisation to use technology under patent that is necessary for industry participants to continue their own research and development activities. 
These matters are relevant to all three of the industry sectors that we have focused on in this research project, namely: the research sector, the company sector and the diagnostics sector. It may be that these issues will be resolved over the next decade or so and a vibrant Australian medical biotechnology industry will be a sustainable goal. Alternatively, these challenges of managing intellectual property in an aggressive environment may impair its development. Bearing this in mind, the final issue that we wish to explore in this Report is the extent to which the law is adequate to ensure that the industry maintains its forward momentum.

We must point out that in this part of the Report we are not attempting to provide a definitive treatise on law reform in this area. What we seek to do is to broadly canvass some of the options for law reform that are relevant to the findings presented in Part 3 of this report. In considering any option for law reform, it should be emphasised that a delicate balance exists in the Australian industry between:

- institution-based researchers who want to continue their important research but at the same time are aware of the need for commercial development and financial support from the private sector;

- upstream companies, which often struggle to obtain financial backing for their research. These companies will often need to access technology from research institutions but will also need to be able to transfer it to downstream partners on favourable terms. Often these downstream partners will be located in other jurisdictions, particularly the United States;

- intermediate companies, which are likewise likely to be heavily involved in accessing technology and in transferring it to downstream partners,;

- downstream companies, which, at this stage, form a small part of the Australian industry. The issue from their perspective is being able to compete effectively with foreign competitors; and

- end users and the providers of products to them. The issue from this perspective is equitable access to high quality new products at a reasonable cost. 
The issue of being able to effectively compete with overseas competitors and in overseas markets is not limited to downstream companies, but is one that is faced by all of the industry sectors. We emphasise that it is vital that law reform in this area does not swing the balance too far against any of these sectors. We briefly canvass a number of options for reform below.

\section{EXCLUDING GENE SEQUENCES}

Discussions about the appropriateness of patenting genes and gene sequences have been going on for over a decade, but to date they have had negligible effect on patent law practice. At the international level, the UNESCO Declaration on the Human Genome and Human Rights states in Article 1 that:

The human genome underlies the fundamental unity of all members of the human family, as well as the recognition of their inherent dignity and diversity. In a symbolic sense, it is the heritage of humanity.

And in Article 4 that:

The human genome in its natural state shall not give rise to financial gains.

The European Biotechnology Directive ${ }^{351}$ states in Article 5.1 that:

The human body, at the various stages of its formation and development, and the simple discovery of one of its elements, including the sequence or partial sequence of a gene, cannot constitute patentable inventions.

Recently the European Parliament passed a resolution specifically relating to the BRCA patents. ${ }^{352}$ Although the Parliament does not have the jurisdiction to legislate to prohibit

351 Directive 98/44/EC On The Legal Protection of Biotechnological Inventions.

${ }^{352}$ Patenting of human genes B5-0633, 0641, 0651 and 0663/2001. 
patenting of human genes it clearly stated its very strong opposition to them in the Resolution. The Resolution expresses the European Parliament's dismay at the possible consequences of granting patents on human genes and called for the European Patent Office to reconsider patenting of genes.

It is important to recognise that gene sequences in their natural state are not patentable. It is only when they have been isolated and synthetically produced and when a function has been ascribed to them that they become patentable. Although Article 27 of TRIPS does not specifically allow for the exclusion of gene sequences, arguably they could be excluded on the basis that they are discoveries rather than inventions. However, this would mark a significant shift from established judicial interpretation of the discovery-invention distinction.

In our view, the difficulties in this area arise more from loose examination of the patent criteria and allowance of broad claims than from allowing gene patenting per se. We do not support the step of prohibiting the patenting of all gene sequences, for the following reasons:

- there is apparent consensus amongst the nations with active research and commercialisation programs in this area that patents should generally be allowed for inventions relating to DNA sequences; ${ }^{353}$

- a significant number of patents have already been granted for a number of inventions that include DNA sequences in their claims, both in Australia and elsewhere; and

- this sort of prohibition will not provide a complete solution to the problem. All it will do is to invite patent attorneys to use their skills in creative drafting to avoid the prohibition. This is precisely what has happened with the ordre public/morality exclusion, the methods of medical treatment exclusion and the plant and animal variety exclusions in Europe, none of which impose any

${ }^{353}$ See, for example, the Joint Statement by United States President Clinton and United Kingdom Prime Minister Tony Blair (March 14, 2000) available at:

http://www.geneticalliance.org/geneticissues/clintonblair.html (accessed 5 July 2002). 
significant limitations on the types of patents being granted in Europe.

\section{EXCLUDING DIAGNOSTIC TESTS}

Article 27 of TRIPS does allow for the exclusion of methods of medical treatment. As previously discussed, there is no express exclusion in the Australian Patents Act 1990 (Cth) and the Federal Court has ruled against a case law exclusion. ${ }^{354}$ Problems encountered (or feared) by diagnostic facilities may well justify amendment to the Patents Act 1990 to specifically exclude diagnostic methods. Whilst there may be some merit in creating this exclusion, further analysis must be undertaken to ascertain whether this would swing the access/innovation public interest balance too far in favour of access, with the consequence that the industry would be discouraged from developing new tests. In addition, it must be emphasised that the permissible ambit of the exclusion can only extend to methods of diagnosis, and not to the diagnostic tests themselves.

\section{PUBLIC INTEREST PROVISION}

Article 27 of TRIPS allows an exclusion where the exploitation of an invention would be contrary to public order or morality. Arguably, an exclusion of this nature could be incorporated into Australian legislation to allow the exclusion of patents where there are sound ethical reasons why patenting is not in the public interest, for example to ensure access to new developments in health care. In the alternative, the courts might read this provision into the general inconvenience exclusion incorporated into Australian patent law through the definition of invention in Schedule 1 of the Patents Act 1990 (Cth). ${ }^{355}$ However, there are a number of problems with both of these options. Most importantly, the TRIPS provision is quite explicit in only allowing the exclusion where the exploitation of the invention

\footnotetext{
${ }^{354}$ See Context Chapter 3.

355 The relevant law in relation to each of these options is discussed in Context Chapter 3.
} 
would be contrary to public order or morality. There is nothing to suggest that the development of diagnostic tests, drugs and devices is contrary to public order or morality. Taking all these considerations into account, it is doubtful that the inclusion of an explicit order public/morality exclusion in Australian patent law would provide a genuine solution to the problem of balancing access rights with patent rights. ${ }^{356}$

\section{INCREASING THE STRINGENCY OF PATENT INVENTION AND DISCLOSURE REQUIREMENTS}

It was noted in Context Chapter 3 that Australian patent law has recently undergone extensive reform, one of the results of which is that the novelty and inventive step criteria have been significantly tightened up. ${ }^{357}$ It is difficult to determine whether these reforms will alleviate concerns about lack of stringency in their application to biotechnology patent applications until a sufficient number of applications has been examined using the new criteria.

We support the introduction of an industrial applicability or utility criterion in Australian law, requiring the Patent Office to adopt the examination practice of requiring specific, substantial and credible industrial applicability/utility. ${ }^{358}$ The IPCRC recommended that this could be achieved through examination of the usefulness requirement in section 18(1)(c) of the Patents Act 1990 (Cth). However, in our view an easier solution may be to amend section 18(1)(a), including after "manner of manufacture" the words "as prescribed". Industrial applicability/utility requirements could then be prescribed in the Patent Regulations. This is in line with United States practice, where utility requirements are prescribed in the form of guidelines. In the alternative, the Patent Office could be directed

\footnotetext{
${ }^{356}$ Note that Australia already has a provision allowing for exclusions based on "general inconvenience", which may allow exclusions based on public policy considerations. See discussion in Part 1 Chapter 3. Also see M. Forsyth 'Biotechnology, Patents and Public Policy: A Proposal for Reform in Australia’ (2000) 11 Australian Intellectual Property Journal 202.

357 Through the Patents Amendment Act 2001 (Cth).

${ }^{358}$ IPCRC, above n47 at 154.
} 
to amend its Patent Manual to include this requirement in its instructions to patent examiners. ${ }^{359}$ However, we believe that a significant change of this nature should have some form of legislative backing.

The views of interview respondents in this study strongly support the need for more stringent examination of biotechnology patent claims. There appeared to be a general view among respondents that excessively broad claims are being allowed by the Australian Patent Office. This could be improved by changes to the Patent Manual. However, again the most appropriate avenue may be to prescribe matters for consideration of section 40 criteria along the lines of the United States written description requirements.

It may also be worthwhile to consider the option of making the opposition and revocation procedures more accessible. In its Report on competition, patent law and policy released in November 2003, the United States Federal Trade Commission highlighted the negative impact of poor quality (or "questionable") patents on competition. The Commission concluded that better procedures need to be put in place to challenge the validity of these questionable patents, recommending that administrative processes should be set up for post grant review and opposition. ${ }^{360}$ The rationale for this conclusion is that:

It is much cheaper for society to make detailed [patent] validity determinations in those few cases [in which patents are challenged] that to invest additional resources examining patents that will never be heard from again. ${ }^{361}$

\footnotetext{
${ }^{359}$ http://www.ipaustralia.gov.au/patents/manual/P_vol2.htm

${ }^{360}$ Federal Trade Commission, above n350.

${ }^{361}$ Ibid, Executive Summary Part II.C, quoting from M.A. Lemley, 'Rational Ignorance at the Patent Office' (2001) 95 Northwestern University Law Review 1495 at 1497.
} 


\section{EXEMPTIONS FROM INFRINGEMENT}

At present there are few recognised defences, or exemptions from infringement, in Australian patent law.

We have already noted in Context Chapter 3 that a number of European countries have provisions in their patent law providing for exemption for private, non-commercial use of a patented invention and for work done "on" the invention (as opposed to work done "with" the invention).

There may be some desirability in introducing these provisions in Australian patent law to provide greater clarity on the extent to which non-commercial research is protected from infringement actions. However, with regard to the first provision, it may be difficult to define precisely which activities are protected, since much of the biomedical research conducted in research institutions is likely to have commercial implications at some stage. Depending on the way that the provision is drafted, it could have as limited applicability as the United States case law exclusion post-Madey. This would seem to provide protection that is too narrow. On the other hand, it is difficult to see why research with a clear commercial focus should be exempt just because it is conducted in research institutions. The second provision could also be expressly included in Australian law, or could be read into existing law. Whilst this will provide greater certainty in respect of work done on patented inventions, it is unlikely to provide much assistance in relation to problems associated with use of those inventions.

\section{COMPULSORY LICENSING / GOVERNMENT USE PROVISIONS}

A compulsory licence is a court or administrative order requiring the patent holder to grant a licence to work the invention, in effect limiting the patent holder's exclusive right to exploit the invention. Government use is self explanatory: use of the invention by the government for the purposes of the state. The justification for these provisions is that encouraging innovation is good for the economy. If a patent is granted and not exploited there is no innovation, and therefore no benefit 
from the patent grant. Innovation is suppressed. In such circumstances, it is recognised that others should be allowed to exploit the invention.

Article 31 of TRIPS allows for use without authorisation subject to certain limitations. The main restriction is that prior to such use, the proposed user must have made efforts to obtain authorisation from the right holder on reasonable commercial terms and conditions and such efforts have not been successful within a reasonable period of time. This requirement may be waived in the following cases:

- national emergency; or

- other circumstances of extreme urgency; or

- public non-commercial use.

Article 31 provides a number of stringent imitations on compulsory licensing and government use. The circumstances in which compulsory licences are allowed vary from country to country. In the United States, the primary ground on which compulsory licences are issued is to remedy anti-competitive conduct. Developing countries are relying on Article 31 to enable domestic manufacture of cheap generic drugs in response to health crisis like HIV/AIDS. The Declaration on the TRIPS Agreement and Public Health does make it clear that it is legitimate to use compulsory licensing-in response to public health crises. ${ }^{362}$

Australia has provisions in the Patents Act 1990 (Cth) that allow a person to apply to court for a compulsory licence where "the reasonable requirements of the public have not been met" (sections 133 and 135). ${ }^{363}$ This provision has rarely, if ever, been used. There are a number of difficulties: attempts must first have been made to obtain a licence; an application has to be made to the Federal Court; there is no judicial guidance on what

\footnotetext{
${ }^{362}$ WTO Doc WT/MIN(01)/DEC/W/2 (adopted 14 November 2001). Note also the subsequent agreement providing for suply of drugs to countries with little or no manufacturing capacity: TRIPS Council (2003) Implementation of Paragraph 6 of the Doha Declaration on the TRIPS Agreement and Public Health available at:

http://www.wto.org/engish/tratop_e/trips_e/implem_para6_e.htm (accessed 26 September 2003).

${ }^{363}$ See also Results Chapter 4.
} 
constitutes the reasonable requirements of the public; and reasonable remuneration has to be paid. Again, there is no judicial guidance on what amounts to reasonable remuneration.

There are also provisions in the Patents Act allowing for exploitation of patents by the Crown or by a person authorised by the Crown, section 163, and also compulsory acquisition, section 171, and assignment, section 172. Exploitation by the Crown under section 163 is limited to exploitation "for the services of the Commonwealth or State" where exploitation is "necessary for the provision of those services". Cases suggest that this provision covers such things as the use by a state rail authority of an invention for the construction of rail carriages ${ }^{364}$ and the use by a local government authority of a meter relating to measurement of water supply. ${ }^{365}$

The fact that the compulsory licensing provisions in the Australian legislation are not made use of suggests on the one hand that they are too difficult and/or costly. On the other hand, it could suggest that they are achieving a desired outcome, in that the availability of the compulsory licensing option actually encourages parties to negotiate a voluntary licence.

Nevertheless, there is justification for reforming these provisions to make them more user-friendly. For example, applications could be made to an administrative body rather than to the Federal Court. ${ }^{366}$ The circumstances in which an application can be made could also be clarified, rather than having to rely on the argument that the reasonable requirements of the public have not been met. Although Article 31 of TRIPS

${ }^{364}$ General Steel Industries Inc v Commissioner of Railways (NSW) (1964) 112 CLR 125.

${ }^{365}$ Stack v Brisbane City Council (1995) 32 IPR 69.

${ }^{366}$ Note that the IPCRC recommended that applications for compulsory licences should be made to the Australian Competition Tribunal, with rights of appeal to the Federal Court. Additional changes to the compulsory licensing provisions were also recommended, specifically repeal of section 135 and the introduction of a competition test. See IPCRC, above n47 at 163. The Government accepted this recommendation in part, preferring to add a competition ground to the existing grounds, rather than to replace them. See IP Australia, Government Response to Intellectual Property and Competition Review Committee Recommendations (Canberra: Commonwealth of Australia; 2003). Available at:

http://www.ipaustralia.gov.au/pdfs/general/response1.pdf (accessed 13 December 2003) (hereafter Government Response). 
does lay down fairly stringent requirements for compulsory licensing provisions in domestic legislation, these are not insurmountable.

One final issue that needs to be considered is that of dependency. Existing compulsory licensing provisions in the Australian legislation deal with situations of dependency, by allowing for the issue of a second compulsory licence when the invention for which the compulsory licence is to be issued cannot be worked without infringing another patent. A second compulsory licence may be granted when the invention for which the compulsory licence is sought "involves an important technical advance of considerable economic importance". ${ }^{367}$ However, as the provisions currently stand there is no express reference to applications for compulsory licensing on the part of the owner of a dependent patent. Presumably a dependent patent holder could only obtain a compulsory licence if the "reasonable requirements of the public" test is satisfied. Given that circumstances of dependency are likely to arise frequently in the area of biotechnology, there may be justification for amending the existing provisions, making special provision for issuance of compulsory licences to dependant patent holders where the invention covered by the dependant patent "involves an important technical advance of considerable economic significance" ${ }^{\text {368 }}$ over the invention for which the compulsory licence is sought.

\section{FAIR USE AND AUTOMATIC/ STATUTORY LICENSING}

We are also of the view that the approach taken to use of materials in the Copyright Act 1968 (Cth) should be examined, with a view to considering the implementation of equivalent use strategies in patent law. In copyright law, the balance between owners and users of copyrighted material is acknowledged to a far greater degree than for patents and is far more prescribed.

\footnotetext{
367 Section 133(3B) Patents Act 1990. See also the discussion of the compulsory licensing provisions in Results Chapter 4.

368 Adopting the current wording of section $133(3 \mathrm{~B})$ as it applies to applicants who seek compulsory licences to work dependent patents and primary patents.
} 
Copyright users can rely on a number of fair dealing defences, particularly for research and study, criticism and review and reporting of news. In addition libraries, being the main users of copyright material have a number of specific defences that they can rely on. The United States has even broader fair use defences. There is some justification in crafting a patent research exemption in the same way as the copyright fair use defences. There could also be other fair dealings, for example in relation to the use of diagnostic tests. ${ }^{369}$ However, the difficulty with this proposition is that the patent holder would not be entitled to any fee for the use of their patented invention, which may not be fair. It may be more appropriate to think of this area in the same way as the educational and other automatic licensing provisions under the Copyright Act 1968 (Cth). Educational institutions have to pay remuneration for the use of copyright material, but they do not have to negotiate individual licences. Nor do they have to apply for compulsory licences. They merely fill out the appropriate remuneration form and pay the appropriate remuneration to approved collection agencies. There are generally standard rates for fees, and if there are disputes these are resolved by the Copyright Tribunal.

In our view, there may be some attraction in creating a statutory licensing scheme for some types of biotechnology patents. The regime might require:

- registration of patents by the owners, putting the onus on them to notify users that they have a patent and will pursue infringers;

- payment of standard licence fees;

- collection of fees by approved collecting agencies;

- the creation of a Patent Tribunal (or extension of the Copyright Tribunal's jurisdiction) to resolve disputes and determine fee structures.

The validity of patents would, of course, remain open to challenge in the courts. The justification for this sort of regulation on the use of patents is that its primary purpose would

\footnotetext{
${ }^{369}$ For a discussion on the applicability of fair use in United States patent law see M.A. O’Rourke 'Towards a Doctrine of Fair Use in Patent Law' (2000) 100 Columbia Law Review 1177.
} 
be to reduce the time and cost expended in patent searches, tracking and pursuing infringers and negotiating licences. At the same time it may also lessen the risk of anti-competitive conduct, increase certainty and decrease individual licence fees but at the same time it would maintain an income stream from licence fees for the patent holder. We are not suggesting that such a scheme would be appropriate for licensing of all types of biotechnology patents. In most instances freedom of contract should be maintained. However, where broad access to patented products or processes is clearly in the public interest, this sort of regime may provide a suitable means of balancing access and incentive to innovate. Examples might include certain patented research tools and diagnostic tests.

Clearly, detailed examinations would be required prior to the implementation of a new regime of this nature. There would have to be some certainty that such a regime would in fact improve access without adversely affecting the rights of patent holders.

Similar provisions already exist in French patent legislation, in the form of ex officio licences or "licence d'office". These are referred to as public authority deeds, which enable the central government to grant a patent licence when public health issues justify it. They contrast with compulsory licences, or "licence obigatoire”, which allow application to the Tribunal de Grande Instance when the patent holder has failed to use the patent.

The remaining question is whether this is allowed by TRIPs. The compulsory licensing provisions in Article 31 may be too restrictive. However, Article 30 allows for limited exceptions to the patent holder's exclusive patent rights provided that they do not unreasonably conflict with normal exploitation of the patent and do not unreasonably prejudice the interests of the patent holder. Arguably a statutory licensing scheme could fall within the concept of a limited exception, provided that it was indeed limited to particular matters. One obvious category would be the provision of medical services, particularly diagnostic services. 


\section{COLLECTIVE RIGHTS ORGANISATIONS}

Perhaps the most significant stumbling blocks in the smooth transfer of technology protected by patents that were consistently identified by participants in our research project were the difficulties, time and cost involved in searching for relevant patents on the one hand, and searching for patent infringers on the other. Negotiating suitable access agreements was the other most consistently perceived hurdle.

These issues are common to the medical and agricultural biotechnology industries. One of the solutions put forward to overcome anticommons and blocking patents issues is the establishment of collective rights organisations, which traditionally comprise cross-licensing arrangements of varying complexity, and patent pools. Collective rights organisations enable the consolidation of intellectual property rights by intellectual property holders so that negotiating contracts with numerous rights holders is streamlined and transaction costs are consequently reduced. A number of commentators have been strong advocates of allowing an industry to evolve to the point where these private arrangements are entered into, because they may be more tailored to particular industries and workable in practice than statutory schemes designed to deal with high transaction costs. ${ }^{370}$ At the same time, other commentators have been pessimistic about the likelihood of emergence of collective rights organisations within the biotechnology industry. ${ }^{371}$

In the area of agricultural biotechnology, one of the solutions that has been proposed is the development of an intellectual

\footnotetext{
${ }^{370}$ See particularly R. Merges, 'Contracting into Liability Rules: Intellectual Property Rights and Collective Rights Organizations', (1996) 84 California Law Review 1293. See also United States Patent and Trademark Office, Patent Pools: A Solution to the Problem of Access in Biotechnology Patents? (2000) at 8.

${ }^{371}$ See, for example, Heller and Eisenberg, above n131; A. Rai, 'Regulating Scientific Research: Intellectual Property Rights and the Norms of Science' (1999) 94 Northwestern University Law Review.77 at 132-5; F.M. Scherer 'The Economics of Human Gene Patents' (2002) 77 Academic Medicine, 1348 at 1363.
} 
property clearing house mechanism. ${ }^{372}$ According to Graff and Zilberman, the goal of a clearinghouse for agricultural biotechnologies would be to:

...reduce transaction costs and other market failures that hinder the exchange of IP, creating pathways through the patent thicket and giving freedom-to-operate with proprietary biotechnologies. ${ }^{373}$

These are precisely the issues that need to be dealt with in the Australian medical biotechnology industry. The question is whether or not a clearinghouse mechanism would be appropriate in this industry.

Again the copyright industry provides a useful model for the establishment of a clearinghouse mechanism. Copyright collecting agencies like the Australian Performing Rights Association (for music), Copyright Agency Limited (for literary works) and Screenrights (for dramatic works) all work on the basis of collecting copyright fees on behalf of their members and distributing them based on statistical sampling techniques. The advantage of this system is that reasonable fees and ease of payment result in high compliance.

This system would not be suitable for all types of biotechnology patents. In particular, drugs and other products that tend to be exclusively licensed would not fit within this model. However, it may be more readily transposed into other areas, particularly bioinformatics, gene sequences and other research tools that tend to be broadly licensed (or ideally should be).

Graff and Zilberman highlight three basic services that a clearinghouse mechanism would have to provide:

372 See G. Graff and D. Zilberman 'Towards an Intellectual Property Clearinghouse for Agricultural Biotechnology (2001) 3 Intellectual Property Strategy Today 1 (hereafter Graff and Zilberman); G. Graff, A. Bennett, B. Wright, and D. Zilberman 'Intellectual Property Clearinghouse Mechanisms for Agriculture: Summary of an Industry, Academia, and International Development Round Table' (2001) 3 Intellectual Property Strategy Today 15 both available at: http://www.biodevelopments.org/ip/ (accessed 20 September 2003).

${ }^{373}$ Graff and Zilberman, ibid at 1. 
- the capacity to identify all relevant intellectual property;

- the establishment of a pricing scheme, terms of contract and royalty disbursement accounting system; and

- an arbitration mechanism. ${ }^{374}$

Other important features include technology specificity, independence, neutrality and the capacity to monitor patent validity. In sum, these are the same sort of features that one would expect of a statutory licensing scheme. The advantage of this scheme is that it is likely to be more economically efficient and compliance by industry is likely to be higher. ${ }^{375}$ The advantage over patent pooling and cross-licensing is that the higher degree of independence makes it less susceptible to anticompetitive practices.

If a clearinghouse scheme and a statutory licensing scheme could be combined in some way to provide a co-regulatory regime, this would be in keeping with the current Federal Government's approach to regulating other areas of new technology. ${ }^{376}$ We suggest that this option deserves closer scrutiny. In particular, a cost-benefit analysis will have to be undertaken, comparing existing costs to the industry, particularly the costs involved in patent searching and negotiating licences with the expense involved in setting up a clearing house system.

\section{THE ROLE OF COMPETITION LAW}

One final matter that needs to be considered is the extent to which patent exploitation may amount to anti-competitive conduct contrary to the Trade Practices Act 1974 (Cth) (hereinafter 'the TPA'). Part IV of the TPA contains a number of provisions dealing with restrictive trade practices, or anti-

\footnotetext{
${ }^{374}$ Ibid at 9.

${ }^{375}$ Ibid at 3-4.

${ }^{376}$ See, for example, the regimes for regulating Internet censorship through the Australian Broadcasting Authority and industry codes in Schedule 5 of the Broadcasting Services Act 1992 (Cth); private sector privacy through the National Privacy Principles and industry codes in the Privacy Act 1988 (Cth) and Internet gambling through the Australian Broadcasting Authority and industry codes in the Interactive Gambling Act 2001 (Cth).
} 
competitive conduct. Probably the most relevant provisions for our purposes are:

- section 45 which regulates collusive conduct between competitors (contracts, arrangements or understandings) which substantially lessens competition;

- section 46 which prohibits a company with a substantial degree of market power from misusing that market power by eliminating or substantially damaging competitors or preventing the entry of potential competitors or deterring or preventing a party from engaging in competitive conduct;

- $\quad$ section 47 which regulates exclusive dealing;

- section 48 which prohibits resale price maintenance (the practice of stipulating the price at which a buyer must resell a product);

- $\quad$ section 50 which regulates anti-competitive mergers.

The grant of a patent in effect gives a patent holder a monopoly over the right to exploit an invention. The patent holder may exploit the invention themselves (or choose not to exploit the invention), or permit other parties to do so. Issues in respect of exploitation arise at the intersection of patent law and competition law. For example, where a patent holder, sole licensee or assignee chooses not to exploit a patent and not to allow any other party to exploit a patent, section 46 of the TPA has the potential to apply if it can be established that the patent holder, licensee or assignee is misusing its market power in a particular market. It is probably only in very rare circumstances that a refusal to license a patent will constitute a contravention of section $46,{ }^{377}$ and the same applies to a complete failure to exploit a patent.

Where a patent holder chooses to allow another party to exploit an invention through a licence arrangement, they are essentially

\footnotetext{
${ }^{377}$ See J. Nielsen 'Biotechnology Patent Licensing Agreements and Anticompetitive Conduct' Centre for Law and Genetics Symposium Regulating the New Frontiers: Legal Issues in Biotechnology, University of Tasmania 10 December 2001. In: Centre for Law and Genetics Occasional Paper No 4 (2002) 35 at 44-5; P. Tucker, 'Refusal to Licence Intellectual Property Rights and Misuse of Market Power - Where is the Line in the Sand?' (1999) 78 Australian Intellectual Property Journal at 86; Radio Telefis Eirann and Independent Television Publications Ltd v Commission [1995] 4 CMLR 718.
} 
giving rights to practice the monopoly granted by the patent. A licence is a contractual arrangement and as already pointed out is governed by principles of freedom of contract. Two related concerns may arise: firstly that the patent monopoly may effectively be extended through these post-grant contractual arrangements, and secondly that the patent holder may restrict the ability of the licensee to practice the invention as fully as the patent holder was entitled to practice it. For example, where patent holders require that licensees give them rights to future inventions developed using the licensed technology by including reach-through provisions in a licence agreement, this may have the effect of discouraging potential licensees from entering into an agreement. This may clearly have a detrimental effect on competition, and thus, competition law may be used to act as a control mechanism over the terms upon which patent licence agreements are entered into.

There are probably limited instances where the use of particular terms in licence agreements flagrantly contravenes the provisions of Part IV. Section 51(3) of the TPA provides some protection to patent holders by exempting terms in patent licence agreements from a number of the Part IV provisions. However, a term will only be exempted to the extent that it 'relates to' the patented invention. A question may arise, for example, as to whether it provides protection where a term claims rights to a future invention, because the term may relate to a new invention rather than the original patented invention. ${ }^{378}$ Section 51(3) has been criticised because it fails to provide intellectual property holders with any certainty, and was the subject of detailed consideration in the IPCRC review. ${ }^{379}$ The Federal Government has indicated that it intends accepting the recommendations of the review committee in relation to section 51(3). ${ }^{380}$

These changes are unlikely to clarify the circumstances in which section 51(3) operates to protect intellectual property holders from contravening Part IV, although a discussion of the specific

\footnotetext{
${ }^{378}$ The Trade Practices Commission, the precursor to the ACCC indicated that it would adopt this position in a Background Paper dealing with intellectual property and competition law; Trade Practices Commission, The Application of the Trade Practices Act to Intellectual Property, Background Paper, (Canberra: AGPS, 1991).

${ }^{379}$ IPCRC, above n47.

${ }^{380}$ Government Response, above n366.
} 
recommendations are outside the scope of this discussion. At present it is far from clear which terms are likely to be caught by section 51(3), and it is likely that the widespread use of potentially anti-competitive terms is commonplace. Policing the use of these terms would involve considerable resources, and there are a number of other reasons why monitoring the use of particular terms in licence agreements is difficult, not least of which is that many agreements are entered into on a confidential basis. $^{381}$ Section 51(3), even in its amended form, will not be without its problems. It is questionable whether it will provide some more certainty to intellectual property holders to enable them to contract freely. An important concern is to avoid dampening both the incentive to innovate and the ability to enter into pro-competitive licence arrangements.

Finally, collaborative arrangements, including patent pooling and cross-licensing arrangements, ${ }^{382}$ may give rise to anticompetitive concerns. If a collaborative arrangement involves collusion and has the effect of substantially lessening competition, it may have the potential to be anti-competitive. ${ }^{383}$ Similarly, companies entering into mergers should be wary of the effect of bundling their intellectual property rights. Although it is difficult to conceive of a situation where a merger between an upstream company or intermediate biotechnology company and a downstream or pharmaceutical company had the effect of dominating a particular market, each case should be individually assessed. The Ciba-Geigy and Sandoz (now Novartis) merger provides a case in point. When investigated by the United States antitrust authorities, the companies entered into a consent decree requiring them to broadly license their patents in the area of human gene therapy to ensure competition in the area. ${ }^{384}$

The balance between patent law and competition law is a fine one, and difficult issues arise. This led the United States Department of Justice and Federal Trade Commission to hold an

\footnotetext{
${ }^{381}$ See, for example, Nielsen, above n377 at 48-50.

${ }^{382}$ On this point see the United States Department of Justice and Federal Trade Commission, Antitrust Guidelines for the Licensing of Intellectual Property (1995). These Guidelines generally recognise the pro-competitive effects of cross-licensing arrangements in particular.

${ }^{383}$ See, for example, J. Barton 'Antitrust Treatment of Oligopolies with Mutually Blocking Patent Portfolios’ (2002) 69 Antitrust Law Journal 851 at 870.

${ }^{384}$ Ciba-Geigy Limited, 123 F.T.C. 842 (1997)
} 
extended set of hearings on the interaction between intellectual property law and competition law. ${ }^{385}$ An examination of comments by many notable speakers at the hearings demonstrates the difficulties that arise from an application of competition law to intellectual property law. The issues are difficult in basic supply markets, but even more difficult in markets for intellectual property rights. Add a market in fairly early stages into the mix, and we must be even more wary of advocating wholesale legal change without carefully examining the effect this is likely to have on the operation of the market.

The discussion on competition law issues contained in this Report is far from exhaustive, and it was not intended that the legal issues associated with applying competition law to intellectual property law be canvassed comprehensively. Our intention was to point to issues that may arise, and to point out that competition law ultimately aims to benefit consumers by increasing the availability of new products. Although competition law may have some role to play, we need to be wary of meddling too much with the fine balance that exists in the marketplace as enthusiasm to innovate may be dampened. An application of competition law should be considered on an individual basis rather than imposed wholesale, and considered as facilitating the continuing development of the industry.

\section{SUMMARY}

Many of the options discussed above focus on regulation to assist users of technology. Others focus on changes to patentability or exclusions from patentability. Some of these require little legal change while others would require considerable work to implement. In these cases, a careful evaluation of each of these options would be crucial. In the next Chapter, we briefly reiterate our key findings before providing a

\footnotetext{
${ }^{385}$ For details see:

http://www.ftc.gov/opp/intellect/index.htm (accessed 10 December 2003).

See also Federal Trade Commission, above n350.
} 
The Legal Landscape

brief overview of how consideration of these options should proceed. 


\section{OUTCOMES CHAPTER 2: CONCLUSIONS}

In this study we aimed to put the debate about the relationship between patenting and medical biotechnology into a practical context. We did this by asking participants in the research institutions, company and diagnostics sectors of the industry to respond to a series of questions about their own research, patents and technology transfer procedures as well as their dealings with other participants' patents and technology transfer operations. We collected quantitative data in the form of written surveys and qualitative data in the form of semistructured interviews.

We framed our analysis against the backdrop of the following matters:

- heightened concerns in Australia about the impact of biotechnology patents, particularly in the research and diagnostics sectors;

- empirical evidence of massive increases in patent activity;

- inquiries into the need for law reform in this area, both in Australia and elsewhere;

- theoretical discussions about the impact of biotechnology patents on innovation, particularly relating to restricted access and anticommons; and

- other empirical studies on the impact of biotechnology patents on the various industry sectors in other jurisdictions.

We envisage that this Report may be a useful policy tool for various government agencies, including, most notably, the ALRC in its current inquiry, Gene Patents and Human Health. Accordingly, material has already been provided to the ALRC during the course of writing this Report. The conclusions reached in this Report are presented in the form of findings rather than recommendations given that we did not have a specific reference to consider these issues. Nevertheless, in our view some of these findings could form the basis of more formal recommendations. Having concluded this study, we are in the process of undertaking further in-depth analysis of a number of the findings presented in this Report. 


\section{STUDY FINDINGS}

We presented our results in seven chapters and followed this with a brief discussion of options for law reform. A key finding is that a very delicate balance exists between the role played by patents in encouraging innovation and the potential for patents to impact negatively on research into, and the development of, new drugs, therapies and diagnostics. Whilst the existing system is not perfect, great care will need to be taken in modifying this system to ensure that the balance is not too greatly disturbed. To adopt the words of Fritz Machlup:

If we did not have a patent system, it would be irresponsible, on the basis of our present knowledge of its economic consequences, to recommend instituting one. But since we have had a patent system for a long time, it would be irresponsible, on the basis of our present knowledge, to recommend abolishing it. ${ }^{386}$

Our primary conclusion is that while there is some scope for legal intervention, given our findings that a fairly vibrant market is developing and operating in Australia, any reform would be at the margins.

To justify this finding we briefly outline the key outcomes of each of our results chapters below. We attempt in this discussion to clarify the main issues for the industry, and identify the legal avenues that might be used to address these issues.

\section{Research and patent issues}

Australian research institutions continue to be rich sources of high quality research results many of which have great potential for commercialisation. Participants in the research sector accept that patenting is an essential component of the commercialisation process. Like company participants, they see that obtaining patents is necessary to ensure the flow of investment for research and development.

\footnotetext{
${ }^{386}$ F. Machlup, An Economic Review of the Patent System (Washington: US Government Printing Service; 1958).
} 
There are some concerns in all sectors of the industry about the breadth of some of the patents that were granted in the 1990s. However, issues surrounding broad patents are being resolved in some jurisdictions. In particular, the USPTO has narrowed the scope of acceptable claims and United States courts are striking down overly broad claims. There was some criticism of the Australian Patent Office by our respondents. In particular, it was felt that the Patent Office was allowing overly broad claims to be granted. The lack of biotechnology case law exacerbates this problem because the Patent Office is not being given any guidance by the courts as to biotechnology claims interpretation. Thus, while problems were identified by our respondents, the issues raised seemed to be related more to resources and application of existing patent law standards rather than the constitution of those standards.

There are ongoing concerns about the impact of gene patents on downstream research. There are also some concerns about research tool patents, although in general they would seem to be of less in issue in Australia than in the United States. We suggest that this is because a number of the more controversial research tool patents have not been granted in Australia and there is little evidence of aggressive enforcement practices in relation to granted patents.

The views expressed by our respondents on the value of particular types of patents depend very much on the position in the industry of the respondent. Respondents in downstream sectors object to upstream patents, whilst at the same time vigorously defending downstream patents. For respondents in the upstream sectors, however, upstream patents are essential to their economic viability.

Whist we strongly agree that it is important to maintain the free flow of raw scientific data as much as possible, this should not be at the cost of unfair discrimination against certain industry sectors. The cascade of patents that flow from the upstream to the downstream sectors of the industry inevitably increase the price of end products, but this has to be balanced against the value of innovation at the upstream end of the industry and the importance of maintaining its economic viability.

\section{Transfer of technology}

Our results show that there is an extensive network of collaborations within the Australian industry, particularly between research 
institutions and upstream or intermediate level companies. Overseas collaborations are particularly important. The mechanisms used to transfer technology within these collaborative arrangements are many and varied. Whilst assignment of patents from research institutions to companies was common in the past, there is now more reluctance to relinquish control over the future development of technology created in the research institution setting.

Some participants in the Australian medical biotechnology industry are capable of bringing their own products to market, particularly in the device sector. However, for the most part, particularly in the drug discovery sector, participants need to be able to transfer their technology downstream. Indeed, in most cases there are a number of intermediate steps from the research sector to the market. Most Australian biotechnology companies fall into the upstream and intermediate sectors. As such, the challenge for the Australian industry is to make their technology attractive to downstream partners. In many cases this will require transfer of technology overseas. Adequate patent protection is just one of the challenges for the industry. At present there appears to be a "buyers' market" in the Australian biotechnology industry. It is very difficult to find suitable downstream partners and negotiate a good deal, but not impossible.

The issues facing the Australian industry to some extent mirror the industry elsewhere. Whilst the rates of technology transfer in Australia are encouraging, the process is not without its impediments. Ways need to be found for making the process as streamlined as possible.

Statutory licensing and/or collective rights arrangements may assist some industry participants, particularly those seeking to license-out widely and non-exclusively.

\section{Issues for research institutions}

Scientists in research institutions in Australia are becoming more knowledgeable about intellectual property issues and research institutions are putting better strategies in place than was the case in the last decade. Some of the important features of good intellectual property strategies include:

- open dialogue between scientists, technology transfer officers and patent attorneys; 
- clean ownership through assignment to the institution (although Melbourne University has the strategy of vesting ownership in the inventor);

- rapid review of publications to ensure that they do not compromise future intellectual property; and

- clear profit sharing arrangements.

Two issues raised by respondents that are of some concern are the quality of patent applications and valuing of technology. Some respondents reported that there is a tendency both to over-file and to over-value. However, as research institutions become more familiar with intellectual property management strategies it is likely that they will find ways to work around these problems.

Many of these issues could be (and are being) addressed through the implementation of better management procedures. In the area of law reform, there is one particular matter that needs to be addressed. The scope of the current research exemption (if it exists at all) is far from clear. Although we would endorse clarification of this exemption, it may be that this would have little practical effect because much biomedical research has commercial implications at some stage.

\section{Restrictions on access}

It would be premature to conclude that exclusionary practices in relation to patented technology within the Australian biotechnology industry are having minimal effect on innovation. There was substantial evidence of exclusionary practices, but this to some extent is to be expected in any patent system. The question we sought to ask is whether exclusionary practices are having a negative impact on innovation and the development of the industry.

Liberal licensing practices of some essential or foundational inventions are evident within the industry. Respondents reported having little difficulty gaining access to broadly applicable research tools and technologies. It was not quite so clear that this was the case with technology useful to produce two competing products. There were a number of scenarios where access to technology of this type appeared to have been restricted in some way, and if so it is possible that innovation may be impeded. Although we cannot conclude with any certainty how frequently this had occurred, we can state that there were certainly instances of it. Many respondents did, however, report being able to either access technology they needed, or redirect their 
research efforts. But access was often gained at a cost. The imposition of terms claiming reach-through rights is commonplace, and numerous other terms that slow the pace of negotiations are frequently sought. Even when a negotiated outcome is reached, the pace of innovation may be slowed. The cost to the industry is significant, but the social cost may be greater.

Some legal options do already exist to deal with these issues, particularly competition law and compulsory licensing. Further examination of statutory licensing and clearing house mechanisms, and of a research exemption may be warranted.

\section{Anticommons issues}

There is no doubt that the increasing complexity of the patent landscape is creating difficulties for the Australian medical biotechnology industry. In particular, searching obligations are onerous and expensive. However, as with other studies, our results suggest that for any particular research project the number of problematic patents is quite small, generally less than five. Nevertheless, we conclude that in part the reason for this is that if there is a higher level of encumbrance research will be redirected. We are unable to state with any level of precision the number of research projects that are abandoned because there are too many problematic patents in the area. However, we know that this problem does exist.

Because of the difficulties encountered by the participants in the Australian industry in licensing-out their patents, they are very conscious about the need to keep their technology as attractive as possible to downstream partners. One of the critical factors is the need to avoid over-encumbrance. Participants in the Australian industry are conscious of royalty stacking and endeavour to keep this to a minimum in their licensing-in activities.

Our respondents do not report significant problems associated with the enforcement of multiple research tool patents. In part this is because a number of the most aggressively enforced research tool patents do not exist in Australia, or, if they do exist, they do not appear to be enforced. However, we expect that these or other patents may well be enforced in the future. Hence it would be premature to say that the Australian industry is free from the rigors of research tool patent enforcement. 
Legal options that may provide assistance in avoiding the undesirable effects of an anticommons include statutory licensing and collective rights arrangements, improved standards for granting patents and possibly a more clearly delineated research exemption.

\section{Impact on end users: the provision of diagnostic services}

Although biotechnology patents will clearly impact on all health care products, our analysis primarily focused on the issue of supply of diagnostic services. In contrast to a recent study in the United States, we found little evidence of enforcement of patents in this area, aside from Roche's PCR patent. We understand that GTG's junk DNA patent is now either being enforced against Australian diagnostic service providers, or is almost certain to be enforced in the near future. It may be possible to negotiate appropriate access rights in relation to this patent.

Respondents in this area had far greater concerns abut the effect of patents on research than respondents from either of the other two sectors. Moreover, many had concerns about the impact of patents on the provision of diagnostic tests to end users. Because the owners of gene patents do have the capacity to exert significant influence on the provision of these services, we suggest that options for law reform should be scrutinised more closely in this area than in others. Many of the legal options already mentioned are relevant here. The option of exempting methods of diagnostic testing could also be further examined.

\section{Market solutions}

When faced with the knowledge that they might be infringing a patent, most of our respondents said that their first option would be to attempt to negotiate a licence. Whilst there is significant collaborative and licensing activity in the Australian biotechnology industry, there are also significant challenges, as noted above. One of the ways that this and other industries have dealt with these challenges is to establish cross-licensing arrangements. There is some evidence of cross-licensing in Australia. However, levels are fairly low and there is no evidence of any sort of systematic approach within particular industry sectors. One of the main ways to avoid patent infringement is to invent around patented technology. This is easier to do in some areas than in others. However, it is generally made more difficult 
when broad patents are granted. Moreover, significant costs are involved in finding appropriate ways to invent around.

One other option when a particular area of research is discovered to be infringing a patent is to ignore it. Many respondents in research institutions rely on the argument that their research is exempt. There is also some evidence of patents being ignored in the company sector. Similarly, in the diagnostics area, it appears that most patents are ignored. The risk from the individual perspective is that if caught the individual could face a large damages award and/or an injunction preventing them from continuing their research. From the broader social perspective, such actions could be seen to be undermining the social value of the patent system.

Patent holders encounter serious difficulties in tracking infringers. In particular, infringement of research tool patents is notoriously difficult to detect. Even when infringement has been detected, enforcement is a high cost procedure and there is a risk that once infringement proceedings are initiated a counter claim could be made for revocation.

We found some evidence to suggest that a practice-based research exemption exists in Australia. Companies are loathe to enforce their patents against researchers in research institutions both because it would creative a negative image against the company and also because research institutions lack the financial resources to make legal challenge worthwhile. However, this attitude may not continue into the future.

Some industry participants will look at the option of challenging the validity of patents, either in pre-grant opposition proceedings or postgrant revocation. However, the costs are significant and such challenges cannot be embarked upon lightly. One of the difficulties this presents in Australia is that because of the costs there are few challenges and because of this there is little in the way of precedent. This increases the risks associated with litigation in this area. One of the problems that this creates is that many patents that may be invalid are never challenged, emphasising the importance of granting good patents or of enabling challenges to questionable patents. Research institution patent holders in particular are unlikely to be able to take the step of challenging competitors' patents because of the lack of resources and risk-averse strategies. 


\section{REFORM OPTIONS}

Although working solutions are being found by industry participants to many of the problems associated with biotechnology patents and technology transfer, some consideration of options for law reform is warranted. The legal solutions canvassed in this Report can be broadly categorised into solutions that regulate the grant of patents and solutions that regulate in some way the manner in which patents are used. We recommend the consideration of a number of options that fall into both categories, and we conclude by identifying these options below.

\section{Regulating the grant of patents}

We do not believe that wholesale reform of the patent granting requirements is desirable. At the same time, this does not preclude a consideration of refinement of patent standards and ways in which the grant of patents might be constrained. Indeed, many commentators have called for such a consideration. For example, two members of the NIH Working Group were of the view that the issues unearthed by that group arose primarily because of the ways in which patent standards were applied in biotechnology. ${ }^{387}$ Fine-tuning the patent system in biotechnology was considered by them to be a necessary exercise.

Our results indicate that there is a need to improve examination practices in Australia to ensure that good quality patents are issued. This is particularly important because pre and post-grant challenges to validity do not occur routinely enough to strike out invalid patents or to provide guidance as to examination of other patents. We are of the view that a gene sequence exclusion or a ordre public/morality exclusion would not add a great deal and may in fact create uncertainty. However, the following legal options warrant further consideration:

- the addition of an industrial applicability/utility requirement at the examination stage and crafting of more biotechnologyspecific guidelines for assessing the description criteria;

- the possible exclusion of methods of diagnostic testing, which would require further analysis; and

\footnotetext{
${ }^{387}$ See NIH above n37 at fn5 of that Report.
} 
- the creation of an express research exemption. Basic and applied research would, however, have to be clearly distinguished.

\section{Regulating the use of patents}

In our view, some of the options outlined in this Report for regulating the use of patents deserve closer scrutiny. However we stress that any proposals for reform should be carefully evaluated before implementation to ensure that they benefit the industry as a whole and not a subset of the industry.

As such, we make the following findings:

- whilst there may be some desirability in relaxing the compulsory licensing procedures, this should not be at the cost of devaluing the patent grant;

- mechanisms to assist with reducing the onerous demands of patent searching and tracking infringement need to be explored. We believe that it may be fruitful to look at coregulatory mechanisms for regulating the use of patents. In this regard, some of the mechanisms employed under the Australian copyright system may provide guidance. However, we recommend that such measures should not be adopted in any wholesale way across the industry. In most instances freedom of contract should prevail. We suggest that it may be appropriate to consider some of these measures in the areas of non-profit research, diagnostics and broadly applicable research tools; and

- finally, any extension of the role of competition law should be evaluated very carefully. Competition law provides an existing vehicle for addressing some access issues, and exists as a remedy in the event of anti-competitive practices. It is, however, rarely utilised in relation to restricted access to intellectual property, and this suggests that there could be some difficulty promoting its use to address exclusionary licensing practices. Given the confidential nature of many transactions involving intellectual property, carving out a role for competition law and the Australian Competition and Consumer Commission may be difficult.

Detailed consideration of these legal options represents the next step in analysis of the way forward for the Australian industry. Our 
Outcomes Chapter 2

intention is to explore these issues using our findings as a basis for this detailed analysis. Each issue raises complex questions and implications for the industry. As such, we would urge caution in implementation of law reform so that the momentum of the industry can be sustained. 


\section{BIBLIOGRAPHY}

\section{LEGISLATION, TREATIES, AGREEMENTS AND DECLARATIONS}

Agreement on Trade-related Aspects of Intellectual Property Rights, Annex 1C in the Final Act Embodying the Results of the Uruguay Round of Multilateral Trade Negotiations, (1994) 33 International Legal Materials 81.

Bayh-Dole Act (35 USC 200 - 212).

Broadcasting Services Act 1992 (Cth).

Declaration on the TRIPS Agreement and Public Health WTO Doc WT/MIN(01)/DEC/W/2 (adopted 14 November 2001).

European Community Directive 98/44/EC On The Legal Protection of Biotechnological Inventions.

Interactive Gambling Act 2001 (Cth).

Patents Act 1990 (Cth).

Patents Amendment Act 2001 (Cth).

Privacy Act 1988 (Cth).

TRIPS Council (2003), Implementation of Paragraph 6 of the Doha Declaration on the TRIPS Agreement and Public Health available at: http://www.wto.org/engish/tratop_e/trips_e/implem_para6_e.htm (visited on 26 September 2003).

\section{CASES}

Aktiebolaget Hassle v Alphapharm Pty Ltd (2002-3) 56 IPR 129.

Bayer AG v Housey Pharmaceuticals, Inc 169 F. Supp. 2d 328 (D. Del. 2001). 
Bayer AG v Housey Pharmaceuticals, Inc 228 F. Supp 2d 467 (D. Del 2002).

Boccari’s Application [1967] AOJP 1380.

Bristol Myers Squibb v FH Faulding \& Co Ltd (2000) 46 IPR 553.

Ciba-Geigy Limited, 123 F.T.C. 842 (1997).

Clayton Furniture Ltd’s Application [1965] AOJP 2303.

Diamond v Chakrabarty 206 USPQ 193 (1980).

F Hoffman-la Roche AG v Bresagen Ltd and New England Biolabs [1997] APO 57 (12 November 1997).

General Steel Industries Inc v Commissioner of Railways (NSW) (1964) 112 CLR 125.

Genetics Institute Inc v Kirin Amgen Inc (No 3) (1998) 156 ALR 30.

Grain Pool of Western Australia v The Commonwealth (2000) 46 IPR 515.

Harvard College v Canada (Commissioner of Patents) (2002) SCC 76.

Joos v Commissioner of Patents (1972) 126 CLR 611.

Lane-Fox $v$ Kensington \& Knightsbridge Electric Lighting Co Ltd [1892] RPC 413.

Madey v Duke University, 307 F 3d 1351, 1360-1 (Fed Cir, 2002).

Murex Diagnostics Australia Pty Ltd v Chiron Corporation (1995) 128 ALR 525.

Murex Diagnostics Australia Pty Ltd v Chiron Corporation [1995] FED No. 961/95.

National Research and Development Corporation v Commissioner of Patents (1959) 102 CLR 252. 
New England Biolabs, Inc v F Hoffman-La Roche AG [2003] FCA 1460 (4 November 2003)

Oncomouse T19/90 [1990] OJEPO 476.

Radio Telefis Eirann and Independent Television Publications Ltd $v$ Commission [1995] 4 CMLR 718.

Regents of the University of California v Eli Lilly \& Co (1997) 119 F3d 1159.

Rehm v Websters Security Systems (1988) 11 IPR 289.

Relaxin [1995] OJEPO 388.

Rescare Ltd v Anaesthetic Supplies Pty Ltd (1993) 25 IPR 119.

Roche Products Inc v Bolar Pharmaceutical Co 733 F 2d 858 (1984).

Stack v Brisbane City Council (1995) 32 IPR 69.

Telefon A/B LM Ericssons Application [1975] FSR 49.

\section{JOURNAL ARTICLES}

Abrams I. and M. Kaiser 'Licensing Transgenic Mice: A Short Tutorial (2000) 12 Journal of Association of University Technology Managers, available at:

http://www.autm.net/pubs/journal/00/transgenicmice.html (accessed 22 October 2003).

Barton J., 'Antitrust Treatment of Oligopolies with Mutually Blocking Patent Portfolios’ (2002) 69 Antitrust Law Journal 851.

Barton J., 'Patent Scope in Biotechnology' (1995) 26 International Review of Industrial Property and Copyright Law 605.

Barton J., 'Patents and Antitrust: A Rethinking in Light of Patent Breadth and Sequential Innovation' (1997) 65 Antitrust Law Journal 449. 
Caulfield T., 'A Colloquy on the Romanow Report. Sustainability of the Health Care and Innovation Agendas: the Commercialisation of Genetic Research’ (2003) 66 Saskatchewan Law Review 629.

Chalmers D. and D. Nicol, 'Commercialisation of Biotechnology: Public Trust and Research’ International Journal of Biotechnology, forthcoming.

Chang H., 'Patent Scope, Antitrust Policy, and Cumulative Innovation’ (1995) 26 Rand Journal of Economics 34.

Cho M.K. and J.F. Merz, 'Letter to Nature’ (1997) 390 Nature 221.

Cho M.K., S. Illangasekare, M.A. Weaver, D.G.B. Leonard and J.F. Merz, 'Effect of Patents and Licenses on the Provision of Clinical Genetic Testing Services’ (2003) 5 Journal of Molecular Diagnostics 3 .

Coase R.H., 'The Problem of Social Cost' (1960) 3 Journal of Law and Economics 1.

Dierker D. and P. Phillips, 'The Search for the Holy Grail? Maximizing Social Welfare Under Canadian Biotechnology Patent Policy’ (2003) 6 IP Strategy Today 45-62.

Eisenberg R., 'Genes, Patents and Product Development' (1992) 257 Science 903.

Eisenberg R. and R. Nelson, 'Public vs. Proprietary Science: a Fruitful Tension?’ (2002) 77 Academic Medicine1392.

Eisenberg R., 'Patents and the Progress of Science: Exclusive Rights and Experimental Use’ (1989) 56 University of Chicago Law Review 1017.

Eisenberg R., 'Proprietary Rights and the Norms of Science in Biotechnology Research’ (1987) 97 Yale Law Journal 177.

Eisenberg R., 'Streamlining the Transfer of Intellectual Property Rights’ (1999) 74 Academic Medicine 683. 
Forsyth M., 'Biotechnology, Patents and Public Policy: A Proposal for Reform in Australia' (2000) 11 Australian Intellectual Property Journal 202.

Graff G. and D. Zilberman, 'Towards an Intellectual Property Clearinghouse for Agricultural Biotechnology (2001) 3 Intellectual Property Strategy Today 1, available at:

http://www.biodevelopments.org/ip/ (accessed 20 September 2003).

Graff G., A. Bennett, B. Wright, and D. Zilberman, 'Intellectual Property Clearinghouse Mechanisms for Agriculture: Summary of an Industry, Academia, and International Development Round Table' (2001) 3 Intellectual Property Strategy Today 15, available at: http://www.biodevelopments.org/ip/ (accessed 20 September 2003).

Green J.R. and S. Scotchmer, 'On the Division of Profit in Sequential Innovation’ (1995) 26 Rand Journal of Economics 20.

Harris A.H., 'Economic Appraisal in the Regulation of Pharmaceuticals in Australia: Its Rationale and Potential Impact' (1994) The Australian Economic Review 99.

Heller M. and R. Eisenberg, 'Can Patents Deter Innovation? The Anticommons in Biomedical Research’ (1998) 280 Science 698.

Heller M.A., 'The Tragedy of the Anticommons: Property in the Transition from Marx to Markets’ (1998) 111 Harvard Law Review 621.

Henry M.R., M.K. Cho, M.A. Weaver and J.F. Merz, 'DNA Patenting and Licensing' (2002) 297 Science 1279.

Kitch E.W., 'The Nature and Function of the Patent System' (1977) 20 Journal of Law and Economics 265.

Lawson C. and C. Pickering, 'Patenting Genetic Materials - Failing to Reflect the Value of Variation in DNA, RNA and Amino Acids' (2000) 11 Australian Intellectual Property Journal 69.

Lemley M., 'The Economics of Improvement in Intellectual Property Law’ (1997) 75 Texas Law Review 989. 
Lemley M.A.,'Rational Ignorance at the Patent Office’ (2001) 95 Northwestern University Law Review 1495

Long C., 'Proprietary Rights and Why Initial Allocations Matter' (2000) 49 Emory Law Journal 823.

Loughlan P., 'Patents: Breaking the Loop' (1998) 20 Sydney Law Review 553.

Merges R. and R. Nelson, 'On the Complex Economics of Patent Scope’ (1995) 90 Columbia Law Review 839.

Merges R., 'Contracting into Liability Rules: Intellectual Property Rights and Collective Rights Organizations', (1996) 84 California Law Review 1293.

Merz J.F., D.G. Kriss, D.D.G. Leonard and M.K. Cho, 'Diagnostic Testing Fails the Test' (2002) 415 Nature 577.

Mikhail P., 'Hopkins v CellPro: An Illustration that Patenting and Exclusive Licensing of Fundamental Science is Not Always in the Public Interest' (2000) Harvard Journal of Law and Technology 375.

Nicol D. and J. Nielsen, 'The Australian Medical Biotechnology Industry and Access to Intellectual Property: Issues for Patent Law Development' (2001) 23 Sydney Law Review 347.

Nicol D., 'Balancing Access to Pharmaceuticals with Patent Rights' (2003) 22 Monash Bioethics Review 50.

Nicol D., 'Human Gene Patents: Under Whose Control?' (2003) 179 Medical Journal of Australia 181.

Nicol D., 'Should Human Genes Be Patentable Under Australian Law’ (1996) 3 Journal of Law and Medicine 231.

Nielsen J. and D. Nicol, 'Pharmaceuticals and Patents: the Conundrum of Access and Incentive' (2002) 13 Australian Intellectual Property Journal 21.

Nottenbaum C., P.G. Pardey and B.D. Wright, 'Accessing Other People’s Technology for Non-profit Research’ (2002) 43 Australian Journal of Agricultural and Resource Economics 3. 
O’Rourke M.A., 'Towards a Doctrine of Fair Use in Patent Law' (2000) 100 Columbia Law Review 1177.

Poste G., 'The Case for Genomic Patenting’ (1995) 378 Nature 534.

Rai A. and R. Eisenberg, 'Bayh-Dole Reform and the Progress of Biomedicine’ (2003) 66 Law and Contemporary Problems 289.

Rai A., 'Fostering Cumulative Innovation in the Biopharmaceutical Industry: The Role of Patents and Antitrust' (2001) 16 Berkeley Technology Law Journal 813.

Rai A., 'Genome Patents: A Case Study in Patenting Research Tools' (2002) 77 Academic Medicine 1369.

Rai A., 'Regulating Scientific Research: Intellectual Property Rights and the Norms of Science' (1999) 94 Northwestern University Law Review 77.

Rimmer M., 'The Attack of the Clones: Patent Law and Stem Cell Research’ (2003) 10 Journal of Law and Medicine 488.

Rimmer M., 'Franklin Barley: Patent Law and Plant Breeders’Rights' (2003) 10(4) Murdoch Electronic Law Journal available at: http://www.murdoch.edu.au/elaw (forthcoming).

Rimmer M., 'Myriad Genetics: Patent Law and Genetic Testing' (2003) 25 European Intellectual Property Review 20.

Saunders T., 'Renting Space on the Shoulders of Giants: Madey and the Future of the Experimental Use Doctrine' (2003) 113 Yale Law Journal 261.

Scherer F.M., 'The Economics of Human Gene Patents' (2002) 77 Academic Medicine 1348.

Scotchmer S., 'Standing on the Shoulders of Giants: Cumulative Research and the Patent Law' (1991) 5 Journal of Economic Perspectives 29 (1991).

Sherman B., 'Governing Science: Patents and Public Sector Research’ (1994) 7 Science in Context 515. 
Tucker P., 'Refusal to Licence Intellectual Property Rights and Misuse of Market Power - Where is the Line in the Sand?' (1999) 78 Australian Intellectual Property Journal at 86.

Walpole I.R., H.J.S. Dawkins, P.D. Sinden and P.C. O’Leary, 'Human Gene Patents: The Possible Impacts on Genetic Service Providers’ (2003) 179 Medical Journal of Australia 203-205;

Walsh J.P., A. Arora and W.M. Cohen, 'Working Through the Patent Problem’, (2003) 299 Science 1021.

Ziman J., 'Is Science Losing Its Objectivity’ (1996) 382 Nature 751.

\section{BOOKS, CHAPTERS IN EDITED VOLUMES AND CONFERENCE PAPERS}

Barber M.N., 'Research Priorities for Australia: Setting Our Future' Telstra Address to the National Press Club, Canberra, 26 June 2002, available at: http://www.science.org.au/academy/media/26june02.htm (accessed 20 November 2003).

Bentley L. and B. Sherman, Intellectual Property Law (Oxford: Oxford University Press, 2001).

Cho M., 'Impact of Patents on Provision of Clinical Genetic Testing Services' (2002) Paper Presented at OECD Workshop on Genetic Inventions, Intellectual Property Rights and Licensing Practices, January 24, 2002, Berlin.

Eisenberg R.S., 'Bargaining Over the Transfer of Proprietary Research Tools: Is This Market Failing or Emerging?' in R.C. Dreyfuss, D.L. Zimmerman and H. First (eds.), Expanding the Boundaries of Intellectual Property: Innovation Policy for the Knowledge Society, (Oxford: Oxford University Press, 2001).

Gutterman A, Innovation and Competition Policy (London: Kluwer Law International, 1997).

Harvey K. and M. Murray, 'Medicinal Drug Policy' in H. Gardner (ed.), The Politics of Health $2^{\text {nd }}$ ed., (Melbourne: Churchill Livingstone, 1995). 
Machlup F., An Economic Review of the Patent System (Washington: US Government Printing Service, 1958).

McGee G. and E. Banger, 'Ethical Issues in Patenting and Control of Stem Cell Research' in Magnus, Caplan and McGee (eds), Who Owns Life? (New York: Prometheus, 2002).

McGinness P., Intellectual Property Commercialisation: A Business Manager's Companion (Sydney: Buttterworths, 2003).

Merges R. and R. Nelson, 'Market Structure and Technical Advance: The Role of Patent Scope Decisions' in Jorde and Teece (eds) Antitrust, Innovation and Competitiveness (New York: Oxford University Press, 1992).

Merton R., The Sociology of Science (Chicago: University of Chicago Press, 1973).

Monotti A. and S. Ricketson, Universities and Intellectual Property (Oxford: Oxford University Press, 2003).

Nielsen J., 'Biotechnology Patent Licensing Agreements and Anticompetitive Conduct' Centre for Law and Genetics Symposium Regulating the New Frontiers: Legal Issues in Biotechnology, University of Tasmania 10 December 2001, in Centre for Law and Genetics Occasional Paper No 4 (2002).

Scherer F.M., 'Comments' in R. Anderson and N. Gallini, (eds) Competition Policy and Intellectual Property Rights in the Knowledge-Based Economy (Calgary: University of Calgary Press, 1998).

Walsh J., A. Arora and W. Cohen 'Effects of Research Tool Patenting and Licensing on Biomedical Innovation' in W.M. Cohen and S.A. Merrill (eds.), Patents in the Knowledge-Based Economy (Washington: National Academies Press, 2003) available at: http://books.nap.edu/books/0309086361/html/285.html\#pagetop (accessed 3 October 2003). 


\section{REPORTS, GUIDELINES AND PAPERS}

Australia's National Medicines Policy available at: http://www.health.gov.au/pbs/natmedpol.htm (accessed 29 November 2001).

Australian Institute of Health and Welfare, Australia's Health 1996 (Canberra: AGPS, 1996).

Australian Law Reform Commission, Issues Paper 27 Gene Patenting and Human Health (2003) at 73-75, available at: http://www.austlii.edu.au/au/other/alrc/publications/issues/27/ (accessed 19 November 2003).

Australian Law Reform Commission, Report No 96: Essentially Yours: the Protection of Human Genetic Information in Australia (2003).

Australian Research Council; Australian Tertiary Institutions Commercial Companies Association; Australian Vice-Chancellors' Committee; Department of Education, Training and Youth Affairs; Department of Industry, Science and Resources; IP Australia; and National Health and Medical Research Council, National Principles of Intellectual Property Management for Publicly Funded Research (Canberra: Commonwealth of Australia; 2001) available at: http://www.arc.gov.au/pdf/01_01.pdf (accessed 1 May 2003).

Biotechnology Australia, Australian Biotechnology: A National Strategy, (Canberra: Commonwealth of Australia, 2000), available at: http://www.biotechnology.gov.au/library/content_library/BA_Biotech _strategy.pdf (accessed 18 November 2003).

Biotechnology Australia, Developing Australia's Biotechnology Future, Discussion Paper, (Canberra: Commonwealth of Australia, 1999).

CHI Research Inc, Inventing Our Future: The Link Between Australian Patenting and Basic Science (Canberra: AGPS, 2000).

Christie A., S. D’Aloisio, K. Gaita, M. Howlett and E. Webster, Analysis of the Legal Framework for Patent Ownership in Publicly Funded Research Institutions (Canberra: Commonwealth of Australia; 2003). 
Commonwealth of Australia, Government Response to Intellectual Property and Competition Review Recommendations (Canberra: Commonwealth of Australia; 2003) available at:

http://www.ipaustralia.gov.au/pdfs/general/response1.PDF (accessed 6 October 2003).

Commonwealth of Australia, The Virtuous Cycle- Working Together for Health and Medical Research, Health and Medical Strategic Review, (Canberra: Australian Government Printing Service, 1999).

Ernst \& Young, Australian Biotechnology Report (Canberra: AGPS, 1999).

Ernst \& Young, Australian Biotechnology Report (Commonwealth of Australia, 2001).

Ernst \& Young, Beyond Borders: the Global Biotechnology Report 2003, (Cleveland: Ernst \& Young LLP 2003)

Guidelines for Examination of Patent Applications (2001) 66 Federal Regulations (US) 1092.

Hopper K. and L. Thorburn, 2002 BioIndustry Review - Australia \& New Zealand, (Canberra: Aoris Nova and Advance Consulting \& Evaluation, 2002).

Howlett M.J. and A.F. Christie, 'An Analysis of the Approaches of the Trilateral and Australian Patent Offices to Patenting Partial DNA Sequences' (ESTS) (2003) IPRIA Working Paper 09/03.

Industrial Property Advisory Committee, Patents, Innovation and Competition in Australia (Canberra: AGPS, 1984).

Intellectual Property and Competition Review Committee, Review of Intellectual Property Legislation under the Competition Principles Agreement Final Report (Canberra: AGPS, 2000).

IP Australia, Australian Patents for: Microorganisms; Cell Lines; Hybridomas; Related Biological Materials and Their Use; and Genetically Manipulated Organisms (Canberra: AGPS, 1998), available at:

http://www.ipaustralia.gov.au/pdfs/patents/specific/biotech.pdf (accessed 20 November 2003). 
IP Australia, Patent Manual available at:

http://www.ipaustralia.gov.au/patents/manual/P_vol2.htm (accessed 28 November 2003).

National Institutes of Health, Report of the National Institutes of Health Working Group on Research Tools (1998), available at: http://www.nih.gov./news/researchtools/index.htm (accessed 3 October 2002).

National Research Council, Intellectual Property Rights and Research Tools in Molecular Biology (Washington DC: National Academy of Sciences, 1997).

Nuffield Council on Bioethics, The Ethics of Patenting DNA: A Discussion Paper, (London: Nuffield Council on Bioethics), available at: http://www.nuffieldbioethics.org/patentingdna/index.asp (accessed 18 November 2003).

Organisation for Economic Co-operation and Development, Genetic Inventions, Intellectual Property Rights and Licensing Practices: Evidence and Policies, (Berlin: OECD, 2002), available at: http://www.oecd.org/dataoecd/42/21/2491084.pdf (accessed 18 November 2003).

Prime Minister's Science, Engineering and Innovation Council Commercialisation of Public Sector Research (2001) Report of Working Group presented at the Council's Seventh Meeting 28 June 2001 at 3, available at:

http://www.dest.gov.au/science/pmseic (accessed 11 November 2003).

Prime Minister's Science, Engineering and Innovation Council Third Meeting Background Paper, Innovation in Medical Biotechnology (1999) available at:

http://www.dest.gov.au/science/pmseic/meetings/3rdmeeting.htm (accessed 3 June 2003).

Prime Minister's Science, Engineering and Innovation Council, University-Industry Linked Research in Australia (1998), available at: http://www.dest.gov.au/science/pmseic/documents/unind.pdf (accessed 18 November 2003). 
Straus J., H. Holzapfel and M. Lindenmeir, Empirical Survey on Genetic Invention and Patent Law, (Munich: 2002) (copy on file with authors).

Trade Practices Commission, The Application of the Trade Practices Act to Intellectual Property, Background Paper (Canberra: AGPS, 1991).

US Congress, Office of Technology Assessment, Federal Technology Transfer and the Human Genome Project (Washington, DC: US Government Printing Office, 1995).

US Department of Justice and Federal Trade Commission, Antitrust Guidelines for the Licensing of Intellectual Property (1995)

US Federal Trade Commission, To Promote Innovation: The Proper Balance of Competition and Patent Law and Policy (Washington: US Government Printing Service; 2003) available at:

http://xml.coverpages.org/ni2003-11-11-1.html (accessed 9 December 2003)

US Patent and Trademark Office, Manual of Patent Examining Procedure, 8th ed., Feb 2003 revision (Washington, DC: United States Patent and Trademark Office, 2003) available at http://www.uspto.gov/web/offices/pac/mpep/index.html (accessed 5 September 2003).

US Patent and Trademark Office, Patent Pools: A Solution to the Problem of Access in Biotechnology Patents? (2000).

\section{WEBSITES}

Advisory Council on Intellectual Property, available at: http://www.ipaustralia.gov.au/about/acip_survey.shtml (accessed 5 December 2003).

AU Published Patent Searching database at: http://apa.hpa.com.au:8080/ipapa/qsearch.

Australian Research Council, available at: http://www.arc.gov.au/grant_programs/centre_stem.htm (accessed 3 June 2003). 
Benitec, available at:

http://www.benitec.com.au/about/core_patents.htm (accessed 3 September 2003).

European Commission's esp@cenet database at: http://ec.espacenet.com/espacenet/ between 20 March and 9 April 2003.

Genetic Technologies, available at:

http://www.gtg.com.au/Media.Coverage.html (accessed 8 December 2003).

Incyte, Intellectual Property, available at:

http://www.incyte.com/control/researchproducts/licensing (accessed 5 September 2003).

Pharmaceutical Benefits Scheme, Consumer Information available at: http://www.health.gov.au/pbs/consumer.htm (accessed 29 November 2001).

\section{HANSARD, PRESS RELEASES, NEWS ITEMS}

Abrams J., 'Lawmakers Weigh Human Organism Patent Ban' Washington Post 26 November 2003, available at: http://www.washingtonpost.com/ac2/wp-dyn/A16205-2003Nov26 (accessed 8 December 2003).

Australian Broadcasting Corporation, 'Patently a Problem' Four Corners broadcast on 11 August 2003, transcript available at http://www.abc.net.au/4corners/content/2003/transcripts/3922059.htm (accessed 12 August 2003).

'Cancer Scientists Contend DuPont Restricts Progress' (3 November 2003) The Los Angeles Times.

'Corporate Takeover' The Boston Globe Magazine, 30 June 2002, available at:

http://www.boston.com/globe/magazine/2002/0224_patent_part2 (accessed 1 July 2002). 
'Federal Leadership Urged as Genetic Testing Resumes' British Columbia Ministry of Health Services, Press Release, (14 February 2003).

Genetic Technologies, 'Genetic Technologies and Myriad Genetics Announce Strategic Licensing Agreement', Press Release, 28 October 2002, available at:

http://www.gtg.com.au/Media.Coverage.html (accessed 8 December 2003).

Genetic Technologies, 'GTG Grants Research License to University of Sydney', 25 July 2003, available at:

http://www.gtg.com.au/Announcements.html\#25jul $\quad$ (accessed 8 December 2003).

Genetic Technologies, 'Genetic Susceptibility Testing - A Third Progress Report' available at:

http://www.gtg.com.au/Media.Coverage.html (accessed 26 June 2003).

Genetic Technologies, 'Presentation by Dr. Mervyn Jacobson, Executive Chairman, to the Annual General Meeting of Genetic Technologies Limited (“GTG”), Melbourne, November 28th, 2003' available at:

http://www.gtg.com.au/Announcements.html\#28nov (accessed 19 December 2003).

Genetic Technologies, Letter from GTG to Medical and Scientific Colleagues, 21 July 2003, available at:

http://www.gtg.com.au/Announcements.html\#21jul (accessed 30 July 2003).

Federal Parliament House of Representatives, Hansard Parliamentary Debates 16 October 1990, 2947.

Federal Parliament House of Representatives, Hansard Parliamentary Debates 16 October 1990, 2947.

Federal Parliament Senate, Hansard Parliamentary Debates 20 September 1990, 2653.

Federal Parliament Senate, Hansard Parliamentary Debates 27 June 1996, 2332. 
Joint Statement by US President Clinton and UK Prime Minister Tony Blair (March 14, 2000) available at:

http://www.geneticalliance.org/geneticissues/clintonblair.html

(accessed 5 July 2002).

Macdonald L., Gene Patenting: Is It Too Late To Stop It? Canadian Breast Cancer Network, 24 April 2002, available at: http://www.cbcn.ca/english/adv_db.php?show\&43 (accessed 12 January 2003). 